\title{
Comparative Assessment of Ceramic Media for Drinking Water Biofiltration
}

by

Dikshant Sharma

A thesis submitted in conformity with the requirements

for the degree of Master of Applied Science

Civil Engineering

University of Toronto

(C) Copyright by Dikshant Sharma 2017 


\section{COMPARATIVE ASSESSMENT OF CERAMIC MEDIA FOR DRINKING WATER BIOFILTRATION}

Dikshant Sharma

Master of Applied Science, 2017

Graduate Department of Civil Engineering

University of Toronto

\section{ABSTRACT}

Biofiltration is an effective drinking water treatment step for the degradation of organic and inorganic constituents. A Lake Ontario pilot-scale study evaluated the performance of an engineered ceramic media as a potential biological media. Overall, the ceramic media was a good alternative to anthracite in terms of biological accumulation and organic carbon removal, especially in cold-water conditions. However, granular activated carbon was superior for dissolved organic carbon (DOC) and disinfection by-product formation potential (DBPFP) removal.

A second biofiltration pilot-study at Lake Erie investigated the removal of inorganic and organic constituents across biological and conventionally operated anthracite filters. The biological filters and conventional treatment effectively removed manganese and iron. However, shifts in water chemistry and extreme turbidity events contributed to manganese leaching from the biological filters. No differences in DOC and DBPFP removals were observed. 


\section{ACKNOWLEDGEMENTS}

This work was funded by the Natural Sciences and Engineering Research Council of Canada (NSERC) Chair in Drinking Water Research (DWRG) at the University of Toronto, and the Ontario Research Fund (ORF).

First and foremost, I would like to thank my supervisor Dr. R.C. Andrews for his continued guidance, encouragement, and inspiration throughout the project. I would also like to thank Dr. Susan Andrews for reviewing my thesis and providing invaluable comments. I am deeply grateful to Liz Taylor-Edmonds for constantly helping me out at every step of the project. I cannot possibly express my gratitude to all of the members of the DWRG - Dr. Ron Hofmann for encouragement, Jim Wang and George Kretescmen (Department of the Earth Sciences) for teaching me the intricacies of analytical instruments, Mike McKie for the pilot plant setup and insightful discussions, Tyler Yang and Chris Jiang for helping in the lab.

Thank you to Dave Scott and staff at the RC Harris Water Treatment Plant, and Carolyn de Groot, Seva Ioussoufovitch, Tijana Rajic, and all the staff at the Elgin Area Water Treatment plant. This project would not have been possible without the continuous efforts and knowledge of extremely talented people at our partner municipalities.

I am especially grateful to my family for supporting me emotionally and financially. I sincerely appreciate all those countless Skype calls from halfway across the globe that made me feel at home. Thanks to all my friends here at the University of Toronto - Divyam, Balsher, Vivek, Appana, Karlye, Kirti, and Maral for continuously supporting me and patiently keeping up with my poor jokes. To my friends scattered around the globe, thank you for believing in me and being there whenever I needed a friend. 


\section{TABLE OF CONTENTS}

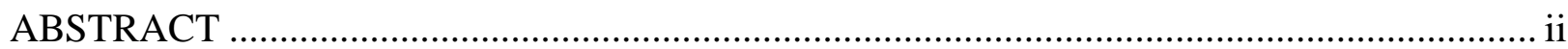

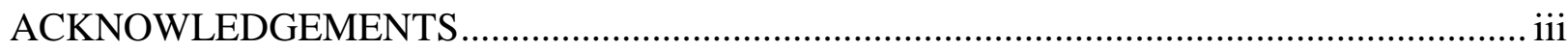

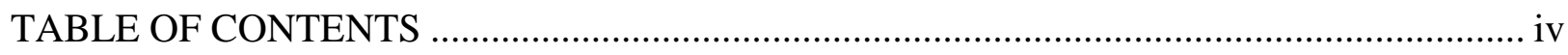

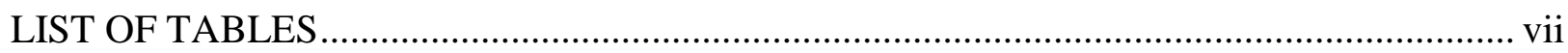

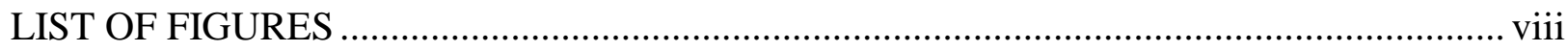

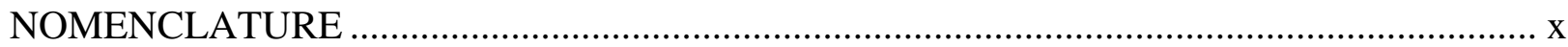

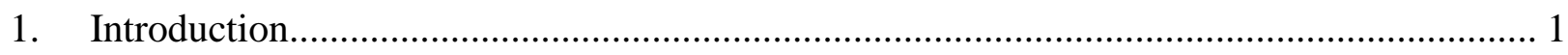

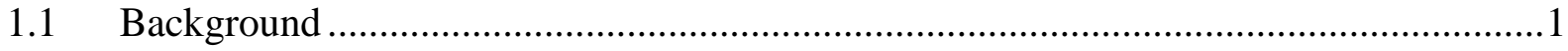

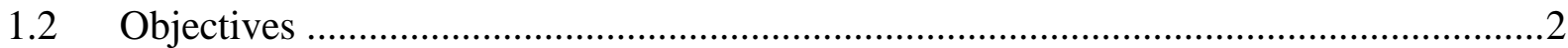

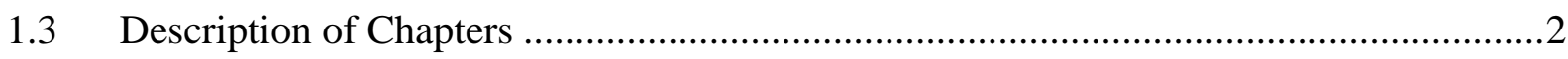

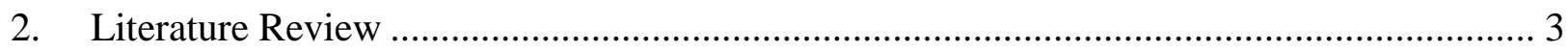

2.1 Biofiltration for Drinking Water Treatment.............................................................

2.1.1 Factors Affecting Biofiltration ....................................................................

2.2 Biomass Quantification and Characterization ...........................................................

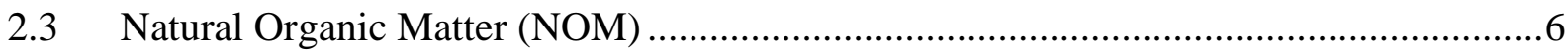

2.4 Disinfection By-Product (DBP) Formation ...............................................................

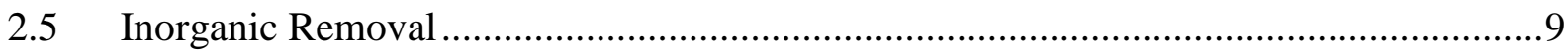

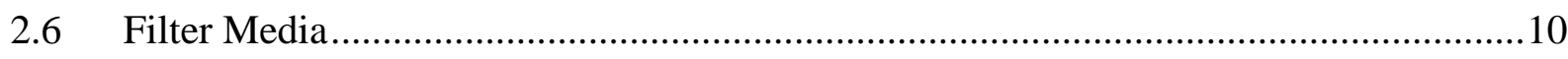

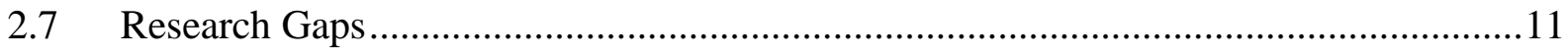

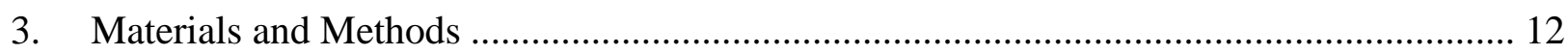

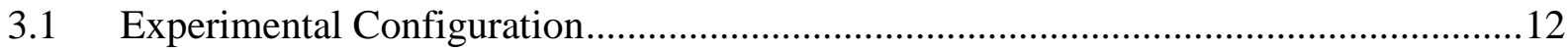

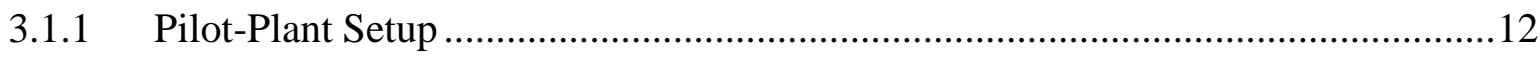

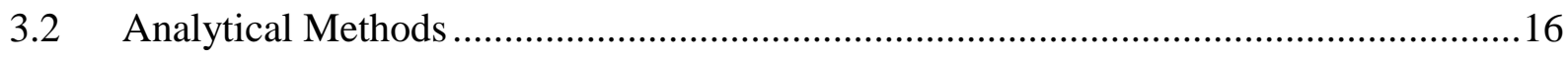

3.2.1 Adenosine Triphosphate (ATP) Analysis .............................................................16

3.2.2 Dissolved Organic Carbon............................................................................ 16

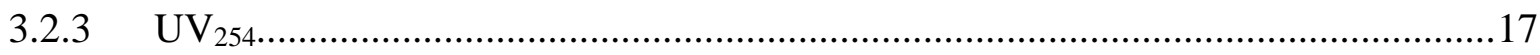

3.2.4 Disinfection By-Product (DBP) Formation Test .................................................18

3.2.5 Trihalomethanes (THMs) ........................................................................... 18

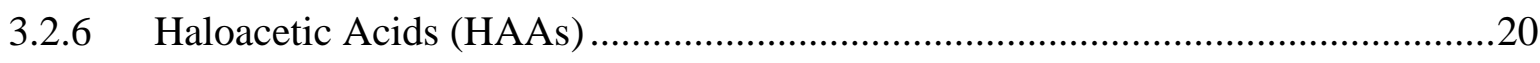




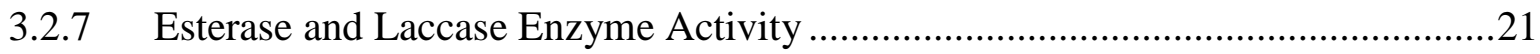

3.2.8 Scanning Electron Microscopy (SEM) Imaging..................................................22

3.2.9 Dissolved Inorganic Elements (Manganese and Iron) ..........................................23

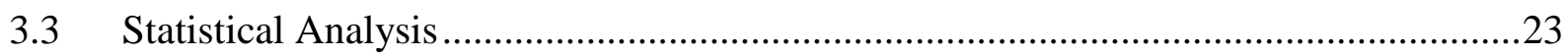

4. Comparative Assessment of Ceramic Media for Drinking Water Biofiltration ................... 24

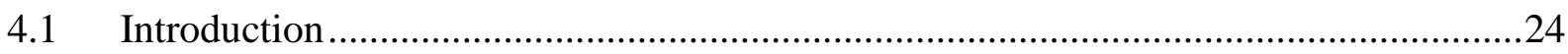

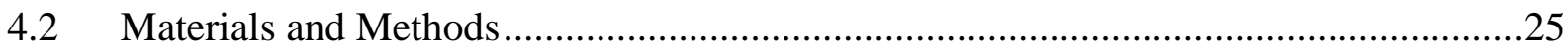

4.2.1 Pilot Plant Configuration .................................................................................25

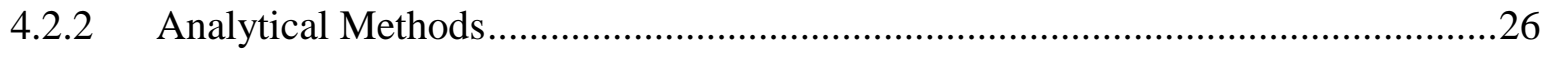

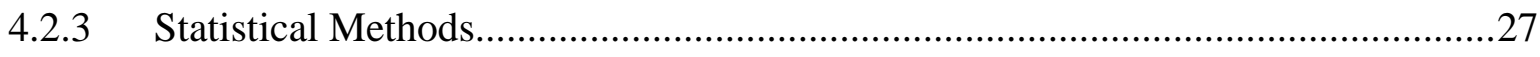

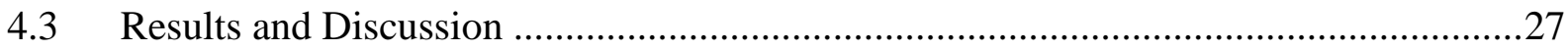

4.3.1 Biological Characterization of the Filter Media ……........................................27

4.3.2 Organics Removal .................................................................................... 31

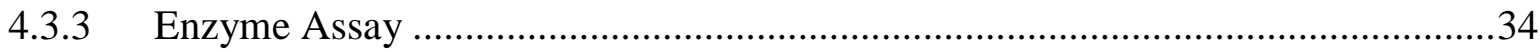

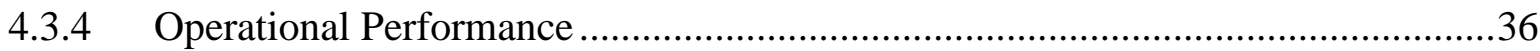

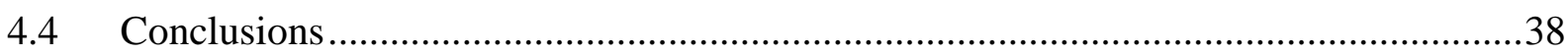

5. Manganese ( $\mathrm{Mn})$ and Iron $(\mathrm{Fe})$ Removal Using Pilot-Scale Biofiltration .......................... 39

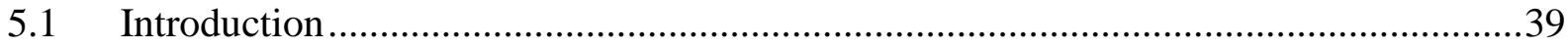

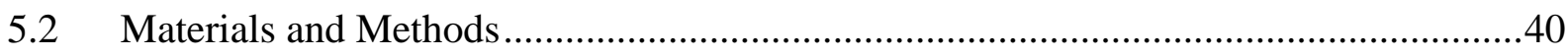

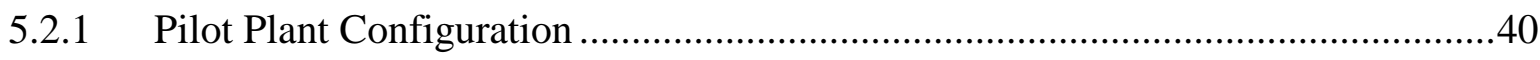

5.2.2 Analytical Methods....................................................................................41

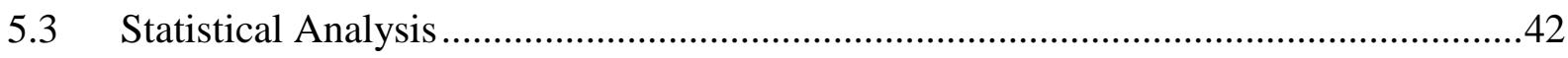

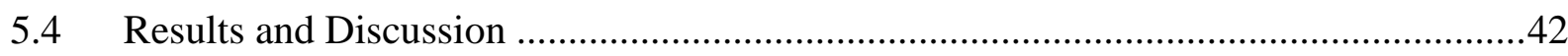

5.4.1 Biological Characterization of the Filter Media ....................................................42

5.4.2 Manganese (Mn) and Iron (Fe) Removal .........................................................43

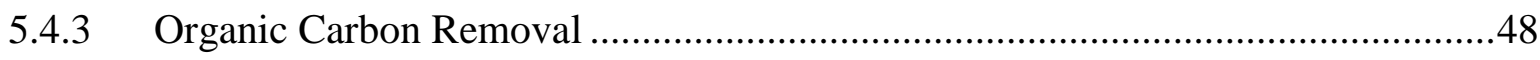

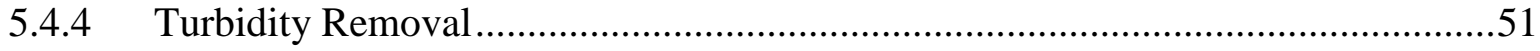

5.4.5 Headloss Buildup ..................................................................................52

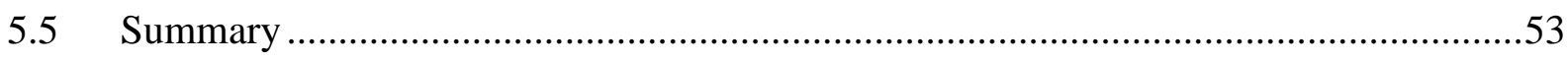

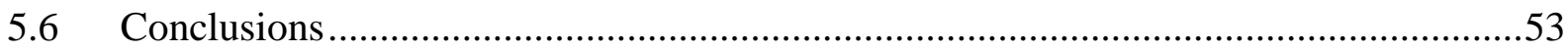


6. Overall Summary, Conclusions, and Recommendations .......................................... 54

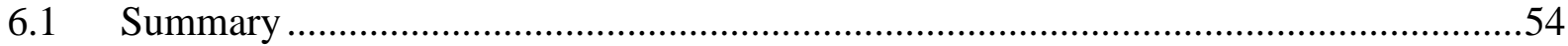

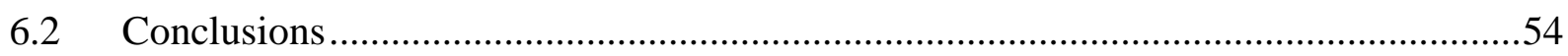

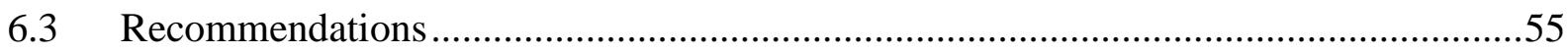

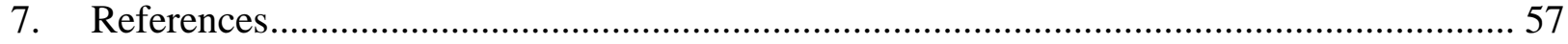

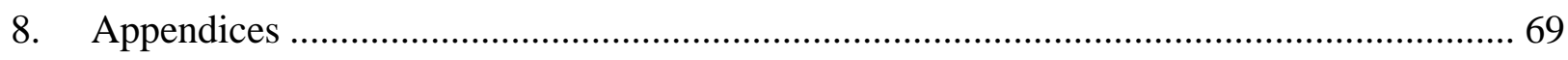

8.1 Standard Operating Procedure Outlines...........................................................69

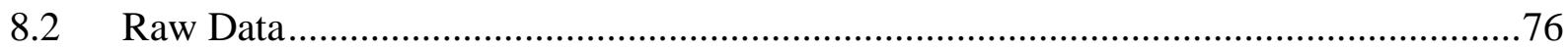

8.3 Sample Quality Assurance/Quality Control (QA/QC) Charts ...................................100 


\section{LIST OF TABLES}

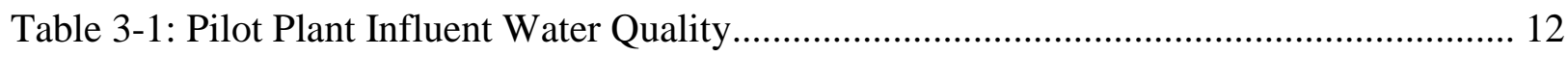

Table 3-2: Physical Properties of the Four Media Types: Lake Ontario Pilot ............................. 14

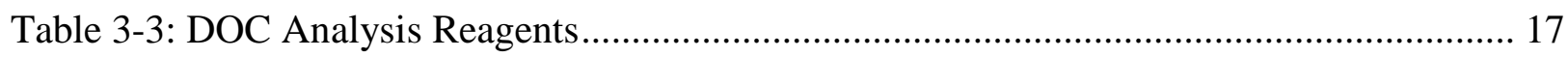

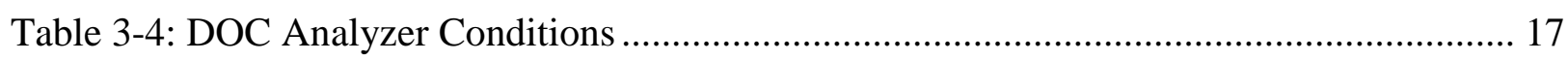

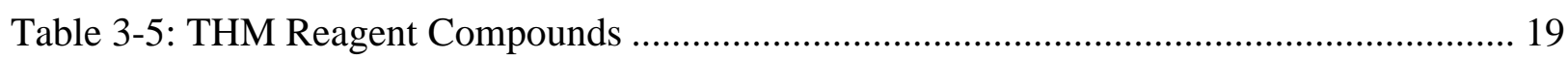

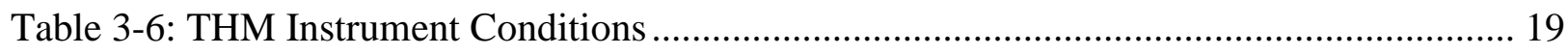

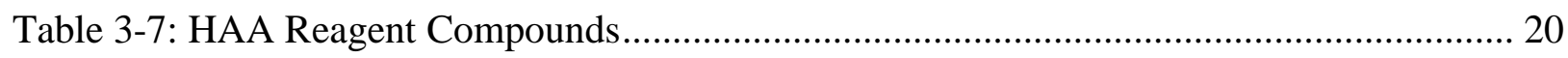

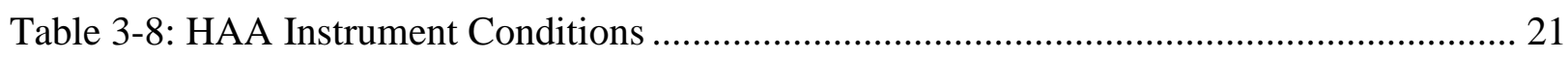

Table 3-9: Enzyme Activity Reagent Compounds .................................................................. 22

Table 4-1: Statistical Comparison of Different Treatments Using Paired T-Tests ..................... 33

Table 5-1: R-Squared Values for Linear Correlations Between Turbidity and Inorganic

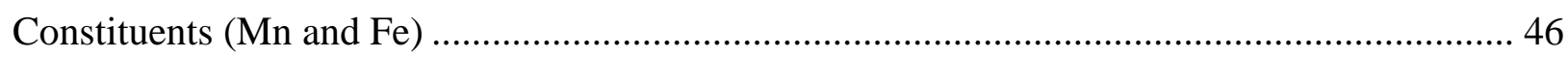

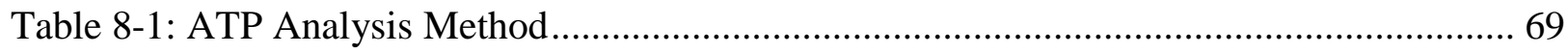

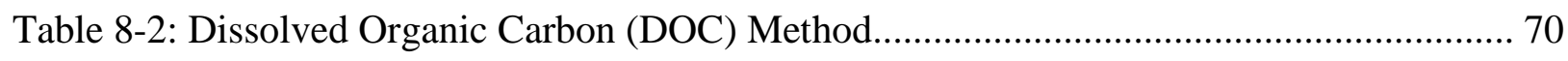

Table 8-3: THM Extraction and Analysis Procedure .............................................................. 70

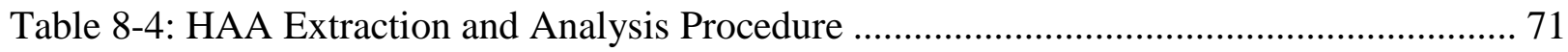

Table 8-5: Enzyme Extraction \& Laccase and Esterase Activity Assay ...................................... 73

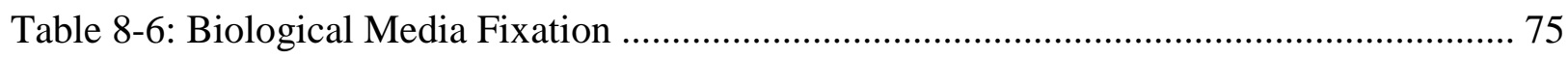

Table 8-7: Raw Data: Lake Ontario Pilot Plant...................................................................... 76

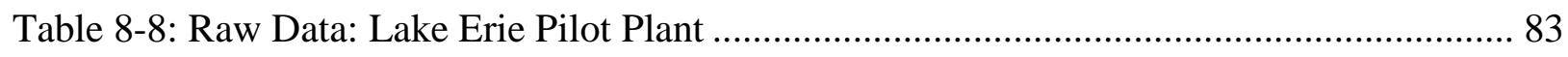

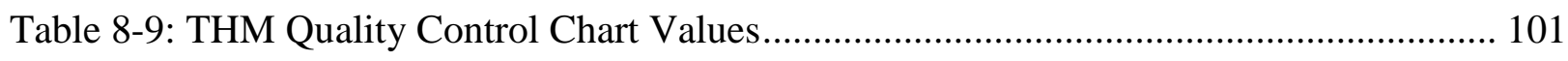

Table 8-10: HAA Quality Control Chart Values ........................................................................ 104 


\section{LIST OF FIGURES}

Figure 3-1: Lake Ontario: Pilot Plant Schematic............................................................. 13

Figure 3-2: Lake Erie: Pilot Plant Schematic. ................................................................ 15

Figure 3-3: Sample Calibration Curve - DOC (April 2016) ............................................... 16

Figure 3-4: Sample BDCM Calibration Curve (February 2016) ............................................ 19

Figure 3-5: Sample HAA Calibration Curve (March 2016) ................................................. 21

Figure 4-1: ATP Concentrations (ng ATP/g media) for Four Different Media Types............... 28

Figure 4-2: SEM Micrographs of Different Filter Media at 5000X Magnification Level ......... 30

Figure 4-3: SEM Micrograph of GAC Filter Media at 1000X Magnification Level................. 31

Figure 4-4: DOC and DBPFP Removals for Lake Ontario Pilot............................................ 32

Figure 4-5: Reaction Rates of Laccase and Esterase ( $\mu \mathrm{mol} / \mathrm{min}-\mathrm{gm})$.................................. 35

Figure 4-6: DOC, THMFP, and HAAFP as a Function of Esterase Activity ( $\mu \mathrm{mol} / \mathrm{min}-\mathrm{g}) \ldots . . . .36$

Figure 4-7: Biofilter Effluent Turbidity Values for Four Different Media Types..................... 37

Figure 4-8: Headloss Development for Four Different Media Types .................................... 38

Figure 5-1: ATP Concentrations (ng ATP/g media) For The Pilot-Scale Filters.................43

Figure 5-2: Average Dissolved Manganese and Iron ( $\mu \mathrm{g} / \mathrm{L})$ Concentrations ...........................44

Figure 5-3: Dissolved Fe $(\mu \mathrm{g} / \mathrm{L})$ Values in Raw, Settled Water, Pilot Filter Effluents.............. 44

Figure 5-4: Dissolved Mn $(\mu \mathrm{g} / \mathrm{L})$ Values in Raw, Settled Water, Pilot Filter Effluents............ 45

Figure 5-5: Relationship between Turbidity (NTU), Fe, and Mn Concentration ( $\mu \mathrm{g} / \mathrm{L})$........... 46

Figure 5-6: DOC Fraction $\left(\mathrm{C} \mathrm{C}_{0}\right)$ Values for Pilot-Scale Filter Effluents............................... 48

Figure 5-7: $\mathrm{UV}_{254}\left(\mathrm{~cm}^{-1}\right)$ Values Pilot and Full-Scale (FS) Filter Effluents. ........................... 49

Figure 5-8: DBPFP (mg/L) for Pilot and Full-Scale (FS) Filters During the Spring and the Summer

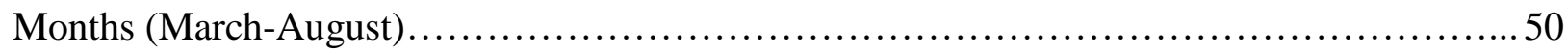

Figure 5-9: DBPFP (mg/L) for Pilot and Full-Scale (FS) Filters During the Fall Months (August-

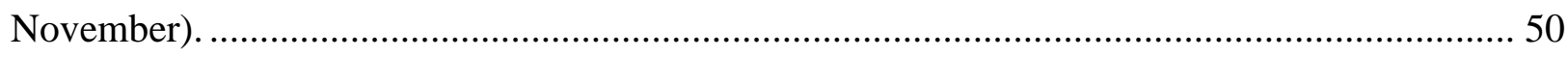

Figure 5-10: Spring and Summer Turbidity (NTU) Value for Pilot Influent and Effluents....... 51

Figure 5-11: Fall Turbidity (NTU) Values for Raw, Settled Water, and Effluents................... 52

Figure 5-12: Headloss (psi) Values for Pilot-Scale Filters.................................................. 52

Figure 8-1: Quality Control Chart for TCM ................................................................. 102

Figure 8-2: Quality Control Chart for BDCM ............................................................ 102 
Figure 8-3: Quality Control Chart for CDBM .............................................................. 103

Figure 8-4: Quality Control Chart for TBM ................................................................... 103

Figure 8-5: Quality Control Chart for MCAA................................................................. 105

Figure 8-6: Quality Control Chart for MBAA................................................................... 105

Figure 8-7: Quality Control Chart for DCAA ............................................................... 106

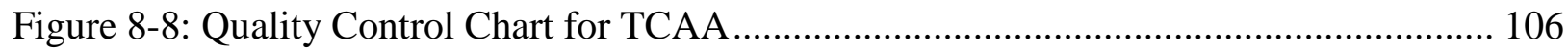

Figure 8-9: Quality Control Chart for BCAA ................................................................ 107

Figure 8-10: Quality Control Chart for DBAA ............................................................. 107

Figure 8-11: Quality Control Chart for BDCAA.......................................................... 108

Figure 8-12: Quality Control Chart for CDBAA …........................................................ 108

Figure 8-13: Quality Control Chart for TBAA ............................................................. 109 


\section{NOMENCLATURE}

\begin{tabular}{|c|c|}
\hline${ }^{\circ} \mathrm{C}$ & Degree(s) Celsius \\
\hline$<$ & Less than \\
\hline$>$ & More than \\
\hline$\sim$ & Approximate \\
\hline $\mathrm{p}$ & Confidence level \\
\hline $1,2 \mathrm{DBP}$ & THM internal standard \\
\hline $2,3,5,6$ TFBA & HAA internal standard \\
\hline 4-MUB & 4-methylumbelliferone \\
\hline Alum & Aluminum sulfate \\
\hline $\mathrm{AOC}$ & Assimilable organic carbon \\
\hline $\mathrm{AOX}$ & Adsorbable organic halides \\
\hline ATP & Adenosine tri-phosphate \\
\hline $\mathrm{BAC}$ & Biologically active carbon \\
\hline $\mathrm{BAF}$ & Biological anthracite filter \\
\hline BCAA & Bromochloroacetic acid \\
\hline BDCM & Bromodichloromethane \\
\hline BDCAA & Bromodichloroacetic acid \\
\hline $\mathrm{BDOC}$ & Biodegradable organic carbon \\
\hline BOM & Biodegradable organic matter \\
\hline $\mathrm{BW}$ & Backwash \\
\hline CAF & Conventional anthracite filter \\
\hline CER & Ceramic \\
\hline $\mathrm{Cl}$ & Chlorine \\
\hline $\mathrm{C}_{0}$ & Initial concentration \\
\hline $\mathrm{cm}$ & Centimeter(s) \\
\hline $\mathrm{C}: \mathrm{N}: \mathrm{P}$ & Carbon: nitrogen: phosphorus ratio \\
\hline CTS & Calcium thiosulphate \\
\hline $\mathrm{D}$ & Diameter \\
\hline
\end{tabular}




\begin{tabular}{|c|c|}
\hline DBAA & Dibromoacetic acid \\
\hline DBCAA & Dibromochloroacetic acid \\
\hline $\mathrm{DBCM}$ & Dibromochloromethane \\
\hline DBP & Disinfection by-product \\
\hline DBPFP & Disinfection by-product formation potential \\
\hline DCAA & Dichloroacetic acid \\
\hline DMSO & Dimethyl sulfoxide \\
\hline DNA & Deoxyribonucleic acid \\
\hline DO & Dissolved oxygen \\
\hline DOC & Dissolved organic carbon \\
\hline EBCT & Empty bed contact time \\
\hline EDX & Energy dispersive X-ray \\
\hline EPS & Extracellular polymeric substances \\
\hline $\mathrm{ES}\left(\mathrm{d}_{10}\right)$ & Effective size \\
\hline $\mathrm{Fe}$ & Iron \\
\hline g & $\operatorname{Gram}(\mathrm{s})$ \\
\hline GAC & Granular activated carbon \\
\hline GC & Gas chromatography \\
\hline GC-MS & Gas chromatography - mass spectrometry \\
\hline GC-ECD & Gas chromatography-electron capture detection \\
\hline $\mathrm{HAA}(\mathrm{s})$ & Haloacetic acids \\
\hline HAAFP & Haloacetic acid formation potential \\
\hline HAN & Haloacetonitriles \\
\hline $\mathrm{HPC}$ & Heterotrophic plate count \\
\hline ICP-OES & Inductively coupled plasma optical emission spectrometry \\
\hline KHP & Potassium hydrogen phthalate \\
\hline $\mathrm{KOH}$ & Potassium hydroxide \\
\hline L-DOPA & L-3,4-dihydroxyphenlaniline \\
\hline $\mathrm{m}$ & Meter(s) \\
\hline $\mathrm{m}^{-1}$ & $1 /$ meter(s) \\
\hline
\end{tabular}




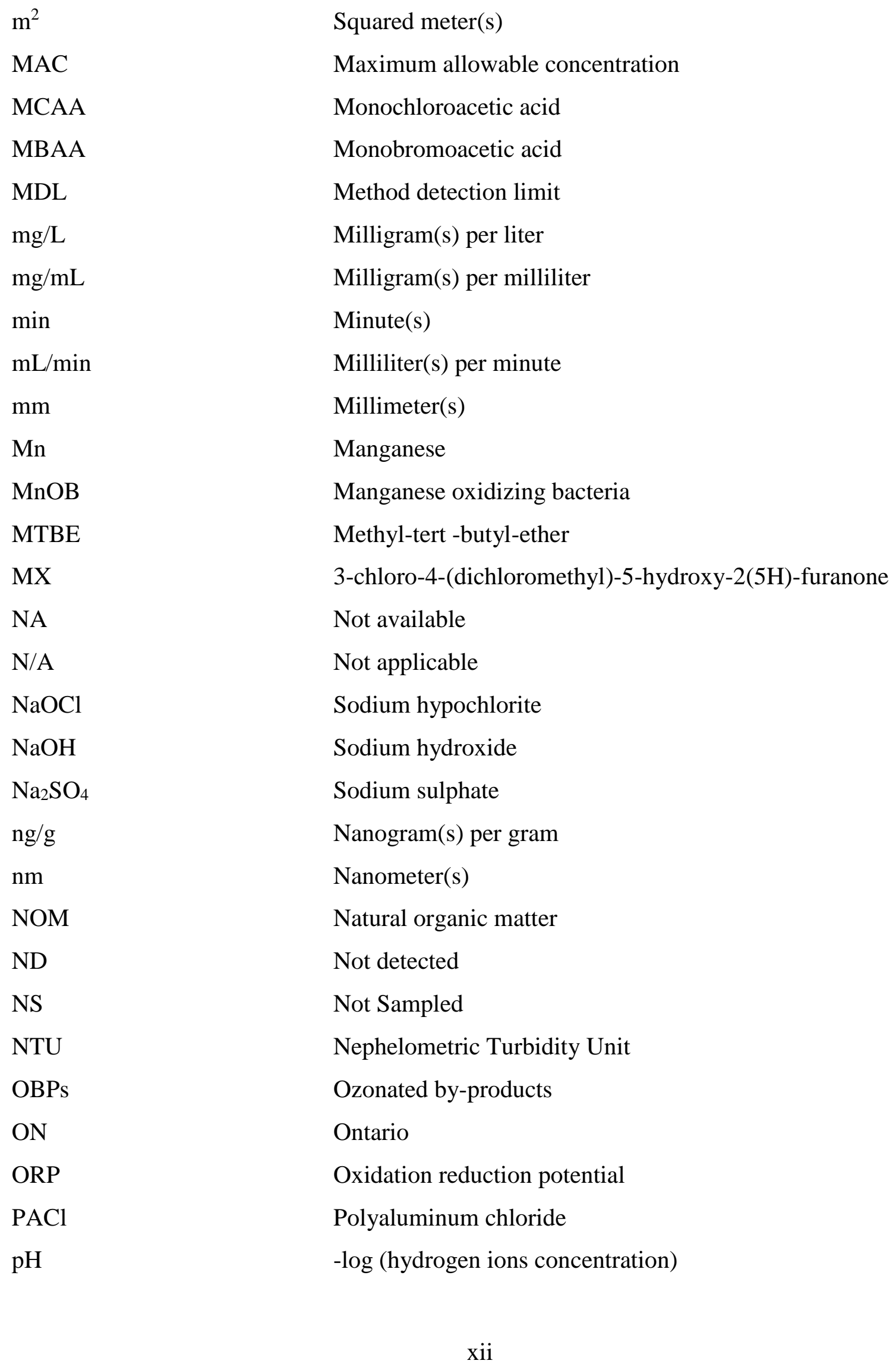




\begin{tabular}{|c|c|}
\hline psi & Pound(s) per square inch \\
\hline QA/QC & Quality assurance/quality control \\
\hline $\mathrm{R}^{2}$ & Coefficient of determination \\
\hline $\mathrm{RBC}$ & Rapid biological filtration \\
\hline $\mathrm{RBF}$ & Riverbank filtration \\
\hline SBS & Sodium bisulphite \\
\hline SEM & Scanning electron microscopy \\
\hline SOP & Standard operating procedure \\
\hline SSF & Slow sand filters \\
\hline SUVA & Specific ultraviolet absorbance (at $254 \mathrm{~nm}$ ) \\
\hline $\mathrm{T}$ & Temperature \\
\hline $\mathrm{t}$ & Student t-test value or student $t$ probability distribution \\
\hline TBM & Tribromomethane \\
\hline TBAA & Tribromoacetic acid \\
\hline TCAA & Trichloroacetic acid \\
\hline TCM & Chloroform \\
\hline TCU & True color units \\
\hline THM(s) & Trihalomethane(s) \\
\hline THMFP & Trihalomethane formation potential \\
\hline TOC & Total organic carbon \\
\hline $\mathrm{T} \& \mathrm{O}$ & Taste and odor \\
\hline $\mathrm{UC}$ & Uniformity coefficient \\
\hline$\mu \mathrm{g} / \mathrm{g}$ & Microgram per grams \\
\hline$\mu 1$ & Microliters \\
\hline UV & Ultraviolet \\
\hline $\mathrm{UV}_{254}$ & UV absorbance at $254 \mathrm{~nm}$ \\
\hline
\end{tabular}




\section{Introduction}

\subsection{Background}

Natural organic matter (NOM) represents carbon-based compounds in source waters derived from decomposition, algal metabolism, and anthropogenic activity (Yavich et al., 2004). In the presence of a disinfectant, NOM will react to form disinfection by-products (DBPs) (Bose and Reckhow, 2007). At the current levels in the drinking water, regulated DBPs do not pose adverse health risks, but few epidemiology studies suggest a weak causal link between DBPs and urinary bladder, colon, and rectal cancer (Hrudey, 2009; Mills et al., 1998). Additionally, presence of manganese $(\mathrm{Mn})$ and iron (Fe) concentrations in source water pose aesthetic, organoleptic, and operational challenges for drinking water utilities (Dixon et al., 2006; Khadse et al., 2013). Even at low concentrations, $\mathrm{Mn}(\sim 0.15 \mathrm{mg} / \mathrm{L})$ and $\mathrm{Fe}(\sim 0.3 \mathrm{mg} / \mathrm{L})$ can contribute to turbidity, taste \& odor, and colour problems, which may stain water pipes, laundry, and plumbing fixtures (Mouchet, 1992). Due to the impact of organic and inorganic constituents on water quality, drinking water utilities strive to optimize their treatment processes to maximize organic and inorganic removals. Conventionally, facilities employ a combination of coagulation, flocculation, filtration, and disinfection processes to achieve contaminants removals below regulatory limits.

Biofiltration is a natural, cost-effective alternative that allows indigenous microbial community to attach and colonize the surface of granular media resulting in the biodegradation of soluble constituents (Zhu et al., 2010). Benefits, include reduction of DBP precursors (Chien et al., 2008), taste and odor compounds (Melin and Odegaard, 2000), membrane foulants (Hallé, 2009), chlorine demand (Melin et al., 2000), iron and manganese (Burger et al., 2008; Granger et al., 2014), and emerging contaminants, including pharmaceuticals and endocrine disrupting compounds (Huck and Sozaski, 2008). Biofiltration implementation and operation in the drinking water industry has begun shifting from a passive to an active approach that targets multiple water quality objectives including organic and inorganic removal, while maintaining acceptable hydraulic capabilities (Lauderdale et al., 2012). Several studies have examined the impact of enhancement strategies, including nutrient enrichment, peroxide addition, and in-line coagulation on biofiltration performance (Azzeh et al., 2015; Lauderdale et al., 2012; McKie et al., 2015). Media type is also a critical design consideration for biofiltration optimization, since it can play 
an important role in enhancing biological activity resulting in higher degradation of organic constituents (Emelko et al., 2006). While the suitability of various alternative media types has been investigated, direct comparisons to conventional media (anthracite and GAC) are lacking, especially at pilot-scale.

\subsection{Objectives}

The aim of this research was to optimize biofiltration performance at pilot-scale with following objectives:

1. Evaluate the biofiltration performance of two different effective sizes $(1.0$ and $1.2 \mathrm{~mm})$ of ceramic media in comparison to conventional media (anthracite and GAC) in terms of dissolved organic carbon (DOC), DBP formation potential (DBPFP), and filter performance (turbidity and headloss).

2. Compare biologically operated filters to conventional filters for the concurrent removal of inorganic (manganese and iron) and organic (DOC, DBPFP) constituents.

\subsection{Description of Chapters}

- Chapter 2: provides review of factors affecting biofiltration performance, natural organic matter (NOM), disinfection-by products, media type, and inorganic removal

- Chapter 3: describes pilot-plant setups, experimental configurations, analytical methods, and statistical analysis

- Chapter 4: evaluates the biofiltration performance of ceramic media in comparison to conventional media (anthracite and GAC)

- Chapter 5: compares biologically operated filters to conventional filters for the concurrent removal of organic (DOC, DBPFP) and inorganic (Mn and Fe) contaminants

- Chapter 6: provides summary, conclusions, and recommendations

- Chapter 7: lists the references cited in this study

- Chapter 8: contains standard operating procedures (SOPs), QA/QC charts, and raw data 


\section{Literature Review}

\subsection{Biofiltration for Drinking Water Treatment}

Biofiltration is a process that allows indigenous microbial community to attach and colonize the surface of granular media for effective degradation of soluble organic constituents (Zhu et al., 2010). Common biological configurations, include slow sand filters (SSF), riverbank filtration (RBF), and rapid biological filtration (RBC) (Kuehn and Mueller, 2000). In the last two decades, biofiltration has gained acceptance due to its ability to remove both organics and particulates (Çeçen and Aktaş, 2011). Benefits also include the removal of DBP precursors (Chien et al., 2008), taste and odor compounds (T\&O) (Melin and Odegaard, 2000), membrane foulants (Hallé, 2009), chlorine demand (Melin et al., 2000), and iron and manganese (Burger et al., 2008; Granger et al., 2014). Moreover, biofiltration has also been shown to be effective for emerging contaminants, including pharmaceuticals and endocrine disrupting compounds (Huck and Sozaski, 2008).

Biofiltration performance is dependent on various factors such as those inherent to the source water (dissolved organic carbon, temperature) as well as operational parameters, including empty bed contact time (EBCT), media type, backwash protocol, and pre-treatment strategies (Liu et al., 2001).

\subsubsection{Factors Affecting Biofiltration}

Concentration and composition of organic matter vary between source waters and can impact biodegradability of dissolved organic carbon (DOC) (Hozalski et al., 1999; Yavich et al., 2004); higher influent DOC concentrations ( $4.3 \mathrm{mg} / \mathrm{L}$ ) correlated with higher biodegradation for biodegradable dissolved organic carbon, BDOC $(\mathrm{r}=0.8)$ and assimilable organic carbon, AOC $(\mathrm{r}$ $=0.5)$ (Persson et al., 2006). Due to variability in source waters, it is important to investigate biofiltration performance at specific locations to understand associated potential benefits.

Water temperature is a critical factor that affects natural organic matter (NOM) metabolism across biofilters (Liu et al., 2001). The increase in organic removal can been attributed to enhanced microbial biodegradation and mass transfer rates (Urfer et al., 1997). For example, a higher reduction in DOC, BDOC, and AOC concentrations (24\%, 60\% and 55\%) was observed across pilot-scale sand biofilters operated at 20 and $35^{\circ} \mathrm{C}$ when compared to $15 \%, 38 \%$, and $43 \%$ 
removals at $5^{\circ} \mathrm{C}$ (Moll et al., 1999). Emelko et al. (2006) reported increased biodegradable organic matter (BOM) degradation across full-scale filters at higher temperatures $\left(21-25^{\circ} \mathrm{C}\right)$ for both GAC (92\%) and anthracite (93\%) in contrast to $56 \%$ and $0 \%$ removals across GAC and anthracite filters, respectively, at lower temperatures $\left(1-3^{\circ} \mathrm{C}\right)$.

Hydraulic loading rate and biofilter depth are key design considerations. Intuitively, longer contact times would allow for increased metabolism of organics. Numerous authors have reported increased NOM removal with longer EBCTs (Urfer et al., 1997; Wang et al., 1995). As EBCT increased from 5 to $20 \mathrm{~min}$, AOC levels decreased from $82 \mu \mathrm{g} / \mathrm{L}$ to $47 \mu \mathrm{g} / \mathrm{L}$ (Lechevallier et al., 1992). In a study conducted by Hallé (2009), anthracite-sand biofilters operated at 14 minute EBCT achieved greater trace organic contaminant removal when compared to filters operating at 5 minute EBCT. However, incremental biodegradation associated with increasing contact times plateaued beyond a threshold value of $\sim 25$ minutes (Hozalski et al., 1999).

Two different media types have been extensively studied for biological removal; GAC (adsorptive) and anthracite (non-adsorptive) (Chien et al., 2008; Liu et al., 2001). The macroporous structure $(>0.5 \mu \mathrm{m})$ and rugged topography of GAC provides good biomass attachment potential (Dussert and Tramposch, 1997). Additionally, GAC provides better protection during stress conditions, including low temperature $\left(1-3^{\circ} \mathrm{C}\right)$, and oxidant application (Emelko et al., 2006; Niquette et al., 1998; Urfer et al., 1997). Improved NOM biodegradation across biological GAC has been well documented when compared to anthracite (Niquette et al., 1998; Persson et al., 2006; Wang et al., 1995). For example, Urfer et al. (1997) reported total organic carbon (TOC) reductions of $51 \%\left(\mathrm{C}_{0} \sim 3 \mathrm{mg} / \mathrm{L}\right)$ across $\mathrm{GAC}$-sand filter when compared to $26 \%$ removals across anthracite-sand filters.

Some studies have linked the superior performance of GAC with continuous bioregeneration of adsorption sites by microorganisms (Aktaş and Çeçen, 2007). However, higher costs and media attrition during backwash limits GAC implementation (Humby and Fitzpatrick, 1996). Recently, engineered ceramic media with promising properties have been developed for biofiltration optimization (Scott, 2008; Wateropolis, 2014).

Backwashing is performed when a filter run is terminated by either reaching maximum allowable headloss $(1 \mathrm{~m})$ or maximum allowable turbidity $(0.1 \mathrm{NTU})$. Studies have examined the impact of the chlorine (in backwash water with air scour and/or collapse pulsing) on NOM 
removals (Emelko et al., 2006; Liu et al., 2001; Miltner et al., 1995). A decrease of 18\% in reductions of both formaldehyde $(4 \mu \mathrm{g} / \mathrm{L})$ and acetaldehyde $(1 \mu \mathrm{g} / \mathrm{L})$ were observed in a full-scale anthracite/sand biofilter when free chlorine residual $(\sim 1 \mathrm{mg} / \mathrm{L})$ was present in the backwash water (Miltner et al., 1995). Biomass concentration (7.5 nmol lipid-P/g), as measured by phospholipid analysis, decreased by $22 \%$ immediately after backwash, but recovered within 12 hours of resuming filter operation. Liu et al. (2001) showed that the presence of chlorine $(\sim 0.5 \mathrm{mg} / \mathrm{L})$ in the backwash water at $5^{\circ} \mathrm{C}$ decreased $\mathrm{BOM}$ removal (formaldehyde and glyoxal) across anthracite filters from $84 \%$ and $55 \%$ to $14 \%$ and $11 \%$, respectively; GAC filters however remained protected from chlorine stress conditions $(\sim 0.5 \mathrm{mg} / \mathrm{L})$ and maintained consistent removals. Use of an air scour and collapse pulsing backwash strategy was shown to have no impact on attached biomass and NOM removals across both GAC and anthracite biofilters (Emelko et al., 2006).

Since biofilters have poor capacity for the degradation of recalcitrant organics, oxidant application (e.g. Ozonation) prior to biofiltration is commonly utilized to enhance NOM removal (Lou et al., 2009). Additionally, biofiltration can limit bacterial regrowth potential in the distribution systems through the metabolism of ozonated by-products (OBPs) formed during ozonation (Persson et al., 2006). The optimum ozone dose typically varies between 0.4-0.6 mg $\mathrm{O}_{3} / \mathrm{mg}$ DOC (Carlson and Amy, 1998; Hozalski et al., 1999). Other enhancement strategies to limit the formation of excessive extracellular material include peroxide $\left(\mathrm{H}_{2} \mathrm{O}_{2}\right)$ addition, and nutrient enhancement (C,N, P) (Lauderdale et al., 2012). The addition of $\sim 1 \mathrm{mg} / \mathrm{L} \mathrm{H}_{2} \mathrm{O}_{2}$ decreased filter head loss by $66 \%$; maintaining C: N: P ratio of 100:10:1 in biofilters decreased headloss and the concentration of extracellular polymeric substances (EPS) by $15 \%$ and $30 \%$, respectively (Lauderdale et al., 2012).

\subsection{Biomass Quantification and Characterization}

Since the removal mechanism of organic carbon across biofilters is predominantly biological, it is important to quantify and characterize the responsible microbial communities (Velten et al., 2011). Numerous methods have been developed to quantify the biomass concentration attached on the filter media, including heterotrophic plate count (HPC) (Hammes et al., 2010); phospholipid analysis (Fonseca et al., 2001; Wang et al., 1995); oxygen consumption (Xiang et al., 2013); and hydrolase enzyme activity (Evans et al., 2013). However, the 
applicability of these methods is limited as they involve complex analytical procedures, difficulty with data interpretation, poor cultivability, and offers no differentiation between live and dead cells (Hammes et al., 2010; Magic-Knezev and van der Kooij, 2004).

Adenosine triphosphate (ATP) has been increasingly used as a surrogate for viable biomass within biofilters (Pharand et al., 2014). It can be easily conducted on site, and provides good sensitivity with low detection limits (Velten et al., 2007). This luminescent-based method involves an initial extraction of ATP from bacterial cells followed by luciferine-luciferase complex reaction to produce light that is measured using a luminometer (Hammes et al., 2010; Magic-Knezev and van der Kooij, 2004). Pharand et al. (2014) reviewed 16 published studies and found that acclimated biofilters ATP concentrations in the top 10-15 cm typically ranged between 100-1000 ng ATP/cm³ media. Similarly, Velten et al. (2011) reported ATP levels between 0.8$1.83 \times 10^{-6} \mathrm{~g} \mathrm{ATP} / \mathrm{g}$ GAC in the filters after 90 days of operation. ATP analysis is a good estimator of viable mass within a biofilter; however, ATP values cannot be directly correlated to biofilter organic degradation potential (Pharand et al., 2014).

\subsection{Natural Organic Matter (NOM)}

Natural organic matter (NOM) is a heterogeneous mixture of carbon-based compounds in source waters as a result of decomposition, algal metabolism, and anthropogenic activity (Yavich et al., 2004). The hydrophobic fraction, the largest fraction of NOM ( 50\%), is composed of humic acids, fulvic acids, and humin, while hydrophilic fraction consists of carbohydrates, amino acids, and sugars (Matilainen and Sillanpää, 2010). The presence of NOM can contribute to color; taste and odor (T\&O) problems (Gibert et al., 2013); disinfection by-products (DBPs) formation (Singer, 1999; Bose and Reckhow, 2007); high coagulant demand, interference with treatment processes (e.g. increased competition for active sites on activated carbon) (Chen et al., 2007; Matilainen and Sillanpää, 2010); biological regrowth within distribution system (Hu et al., 1999). Due to the impact of NOM on finished water quality, it is imperative for drinking water utilities to optimize their treatment processes to maximize organic removal.

NOM can be characterized based on physical and chemical properties (Chen et al., 2011). The concentration of NOM is commonly expressed in terms of dissolved organic carbon (DOC), UV absorbance at $254 \mathrm{~nm}$ (UV254), and color (TCU). Specific UV absorbance (SUVA), which 
is UV absorbance (254 $\mathrm{nm}$ ) of a water normalized with DOC concentration, is another useful indicator for the hydrophobicity of NOM. A high SUVA value (>4) suggests presence of humics, while a low SUVA value $(<2)$ is representative of non-humics (Edzwald and Tobiason, 1999). These analytical methods can be easily performed for gross estimation of the organic content; however, they provide limited information regarding biological process optimization.

\subsection{Disinfection By-Product (DBP) Formation}

In the presence of a disinfectant, NOM will react to form disinfection by-products (DBPs) (Chaiket et al., 2002). The major classes of halogenated DBPs identified in water sources, include trihalomethanes (THMs), haloacetic acids (HAAs), haloacetonitriles (HANs), cyanogen halides, halopicrins, haloketones, and haloaldehydes (Singer, 1994). THMs, a regulated class of DBPs, represent four chemical compounds: chloroform, bromoform, bromodichloromethane, and dibromochloromethane, while another important class HAAs include a total of nine halogenated acetic acids (Health Canada, 2008, 2006). Numerous toxicological studies, in the past 30 years, have attempted to understand the public health risks of DBPs, but the data has not shown causal link between DBPs consumption from drinking water and adverse health and reproductive outcomes in humans (Hrudey, 2009). However, few epidemiology studies, 12 out of 33, are suggestive of DBPs causal link with urinary bladder, colon, and rectal cancer (Hrudey, 2009; Mills et al., 1998). In conclusion, regulated DBPs pose no real adverse health risk at the current levels in the drinking water, and immense efforts are underway to characterize risks from unknown chlorinated by-products. Health Canada has established a precautionary regulation of maximum allowable concentration (MAC) of $100 \mu \mathrm{g} / \mathrm{L}$ for total THMs and proposed $80 \mu \mathrm{g} / \mathrm{L}$ for HAA5s (Health Canada, 2008, 2006).

Regulated DBPs are just the tip of the iceberg as more than 700 DBPs have been identified. The known DBPs account for no more than $\sim 40 \%$ of the absorbable organic halide (AOX) concentration (Krasner et al., 2006). Furthermore, AOX measurements exclude contributions from non-halogenated DBPs, such as aldehydes and carboxylic acids. Thus, the concentration of DBPs could be greater than the measured AOX values (Richardson, 2003). Due to the difficulty in quantifying the relative contribution from different components, disinfection by-product formation potential (DBPFP) serves as a useful surrogate to predict DBP concentrations. This 
enables drinking-water utilities to optimize their treatment processes to reduce DBP levels in the finished water (Chen and Westerhoff, 2010; Delatolla et al., 2015).

To reduce chlorine application and avoid formation of DBPs, use of alternative disinfectants is considered (e.g., ozone, chlorine dioxide, and chloramines). While this can minimize the levels of regulated DBPs, it can lead to formation of other unknown by-products which are poorly characterized in terms of toxicity (Richardson, 2003). In addition, the presence of bromide or iodide in source waters affects DBPs speciation for THMs and HAA; where brominated and iodinated DBPs are shown to be more carcinogenic than chlorinated DBPs (Richardson, 2003). Another compound, MX (3-chloro-4-(dichloromethyl)-5-hydroxy-2(5H)furanone), has been found to contribute between $20-60 \%$ of the total mutagenicity in the treated drinking water samples (Smeds et al., 1997). In 2002, a US DBP Occurrence Survey reported the formation of various brominated and iodinated-DBPs, and brominated MX with alternative disinfectants (ozone, peroxide, and chloramines) (Weinberg et al., 2002). Therefore, it is important to mitigate the hazards associated with regulated DBPs while minimizing the risk from unknown, emerging DBPs in an efficient but cost-effective manner.

\section{DBPs Control Strategies}

Many studies have focussed on the removal of DBP precursors through enhanced coagulation (Wang et al., 2002; Bolto et al., 2002), granular activated carbon (GAC) adsorption (Babi et al., 2007; Capar et al., 2002), membrane filtration (Konieczny et al., 2009; Zularisam et al., 2009), alternative disinfectants and oxidants (Bond et al., 2009; Bose and Reckhow, 2007) and biologically active filtration (BAF) (Lauderdale et al., 2012; Lou et al., 2014).

The coupling of oxidation processes with biological treatment is commonly adopted for DBP precursors removal (Delatolla et al., 2015). Ozonation oxidises recalcitrant organics into biodegradable organic matter $(\mathrm{BOM})$, and enhances biofiltration ability to reduce the concentration of AOC and DBPs precursor to achieve biologically stable water (Lou et al., 2009). Persson et al. (2006) reported that direct biofiltration of surface water can reduce AOC and BDOC concentrations by $30 \%$ suggesting that biofiltration operation in active mode can be a costeffective alternative for NOM removals. 


\subsection{Inorganic Removal}

The presence of dissolved manganese ( $\mathrm{Mn})$ and iron (Fe) in source waters pose aesthetic, organoleptic, and operational challenges for drinking water utilities (Khadse et al., 2013). Even at low concentrations, $\mathrm{Mn}(\sim 0.15 \mathrm{mg} / \mathrm{L})$ and $\mathrm{Fe}(\sim 0.3 \mathrm{mg} / \mathrm{L})$ contribute to turbidity, taste \& odor, and colour problems, which may stain water pipes, laundry, and plumbing fixtures (Mouchet, 1992). In addition, neurotoxic effects in children have been reported at Mn concentrations greater than $200 \mu \mathrm{g} / \mathrm{L}$ (Bouchard et al., 2011). Health Canada mandated an aesthetic objective of 0.05 $\mathrm{mg} / \mathrm{L}$ and $0.3 \mathrm{mg} / \mathrm{L}$ for $\mathrm{Mn}$ and Fe, respectively (Health Canada, 2012).

Traditional physico-chemical approaches for inorganic removal include a primary step, such as chemical oxidation $\left(\mathrm{O}_{3}, \mathrm{ClO}_{2}\right.$, and $\left.\mathrm{KMnO}_{4}\right)$, aeration, or use of $\mathrm{Mn}$ greensand followed by filtration /biofiltration (Somerfield 1999). Continuous application of chemical oxidant is the most common approach; where oxidation reduction potential (ORP) is increased such that dissolved $\mathrm{Mn}(\mathrm{II}) / \mathrm{Fe}(\mathrm{II})$ are oxidized and precipitate as insoluble oxides of $\mathrm{Mn}(\mathrm{IV}) / \mathrm{Fe}(\mathrm{III})$ (Kohl and Medlar, 2006). However, continuous maintenance of desired ORP regime is difficult in practice.

Biofiltration has been shown to effectively remove inorganics with lower operation and maintenance $(\mathrm{O} \& \mathrm{M})$ costs at higher throughput rates when compared to chemical treatment (Burger et al., 2008). During biofiltration, soluble Mn and Fe are metabolized by Mn- and Feoxidising bacteria either through direct microbial enzymatic oxidation or indirect modification (elevated $\mathrm{pH}$ and/or ORP) (Diem and Stumm, 1984). The bacterial community can oxidize soluble $\mathrm{Mn}$ and Fe to insoluble oxides of Mn(IV) and Fe(III) which then precipitate on the bacterial surface and become integrated within the biofilm (Sahabi et al., 2009). Integration of biologically oxidised inorganics provides stability and prevents further desorption of Mn and Fe (Sahabi et al., 2009).

Much of the published literature concerning inorganic removal using biofiltration is related to ground water (Burger et al., 2008; Katsoyiannis and Zouboulis, 2004; Qin et al., 2009) while only few studies have investigated surface water. Lauderdale et al. (2012) reported a $98 \%$ Mn removal when nutrients and oxidants were added prior to pilot-scale biofilters. The authors however, did not pinpoint whether the removal mechanism was microbial metabolism or peroxide oxidation. Kohl and Dixon (2012) examined several surface waters and reported that full-scale 
biofiltration could achieve $>97 \% \mathrm{Mn}$ removal when the $\mathrm{pH}$ was between 7.2-7.6. Granger et al. (2014) demonstrated a $91 \%$ Mn removal $\left(\mathrm{C}_{0}=327 \pm 277 \mu \mathrm{g} / \mathrm{L}\right)$ in phosphorus enhanced bench-scale biofilters for $\mathrm{pH} 6$ surface water, while only 70\% Mn removal was observed with alkaline conditions ( $\mathrm{pH} 9-11)$.

\subsection{Filter Media}

Previous studies have shown that media type can play an important role in enhancing biological activity resulting in higher degradation of organic constituents (Emelko et al., 2006; Liu et al., 2001). Media selection depends on variety of factors including, uniformity coefficient (UC), effective size (ES), surface roughness, and density. It is also dictated by specific treatment objectives such as removal of organics or extending filter run time. The most commonly used dual-media configurations include anthracite/sand and granular activated carbon (GAC)/sand (Pharand et al., 2014). While alternative media such as crushed apricot stones (Aksoğan et al., 2004), polyurethane foam filter (Biswas et al., 2003), crushed glass, pumice (Kitis et al., 2007) and compressible rubber granules (Valdes and Liang, 2006) have also been investigated, direct comparison to conventional media is lacking.

Ceramic media is manufactured by burning clay at $\sim 1200^{\circ} \mathrm{C}$, which is then crushed and sieved to obtain desired properties (Saltnes et al., 2002). The low density of ceramic media allows for shorter backwash times with lower energy/water requirements. In addition, the higher effective size can potentially reduce headloss and improve filter run times. It has good abrasion resistance and therefore a low attrition rate against physical impacts is anticipated when compared to GAC (Melin and Ødegaard, 1999).

Melin and Ødegaard (1999) investigated ceramic media at pilot-scale and reported TOC reductions of $13-28 \%\left(\mathrm{C}_{0}=2-5 \mathrm{mg} / \mathrm{L}\right)$ across biofilters when supplied with synthetic raw water containing a humic concentrate which had been pre-treated with ozonation. However, direct comparison to conventional media, GAC or anthracite, was not conducted in this study. The use of engineered media has not been explored relative to conventional anthracite and GAC and merits further investigation. It can be used as a direct replacement for anthracite/GAC or as an additional capping on dual-media filters to achieve longer filter runs and enhanced biofiltration performance in terms of DOC and DBPFP removals. 


\subsection{Research Gaps}

Biofiltration implementation and operation in the drinking water industry has begun shifting from a passive to an active approach that targets multiple water quality objectives including organic and inorganic removal, while maintaining acceptable hydraulic capabilities (Lauderdale et al., 2012). While several studies have examined the impact of enhancement strategies, including nutrient enrichment, peroxide addition, and in-line coagulation on biofiltration performance (Azzeh et al., 2015; Lauderdale et al., 2012; McKie et al., 2015), the impact of media type is also a critical design consideration.

Ceramic media can potentially overcome the limitations associated with natural media. It can be produced with high surface area; macro-porous surfaces are ideal for biofilm attachment. The use of ceramic media to improve biofilters performance has not been extensively studied before in contrast to conventional media (GAC and anthracite). A comparative assessment of ceramic media performance in terms of organic carbon removal, operational performance, DBP formation potential, and biological activity should be conducted in comparison to conventional media.

The removal of inorganic contaminants $(\mathrm{Mn} / \mathrm{Fe})$ from drinking water with pilot-scale biofiltration should also be examined. Burger et al. (2008) reported 100\% Mn removal from groundwater using four full-scale biofilters. However, the authors had difficulty in ensuring consistent influent water characteristics with use of modified tap water (altered $\mathrm{pH}$, chlorine and metals concentrations) to simulate ground water. Much of the published literature concerning inorganic removal using biofiltration is related to ground water, while only few studies have investigated surface water. A pilot-scale study should be conducted at a full-scale plant to determine the impact of influent water characteristics on the concurrent removal of inorganic and organic constituents across biofilters. 


\section{Materials and Methods}

\subsection{Experimental Configuration}

\subsubsection{Pilot-Plant Setup}

Pilot-scale biofiltration studies were conducted at the RC Harris Water Treatment Plant (WTP) located on Lake Ontario in Toronto, ON, Canada and at the Elgin Area Water Treatment Plant located on Lake Erie in London, ON, Canada. Influent water quality parameters are presented in Table 3-1.

Table 3-1: Pilot Plant Influent Water Quality

\begin{tabular}{|c|c|c|}
\hline Parameter & Lake Erie & Lake Ontario \\
\hline Temperature $\left({ }^{\circ} \mathrm{C}\right)$ & $8.8-24.3$ & $14-24$ \\
\hline $\mathrm{pH}$ & $6.6-7.4$ & $7.2-7.9$ \\
\hline Turbidity $(\mathrm{NTU})$ & $0.2-3.8$ & $0.2-1.0$ \\
\hline DOC $(\mathrm{mg} / \mathrm{L})$ & $1.4-1.8$ & $1.8-2.3$ \\
\hline $\mathrm{UV}_{254}\left(\mathrm{~cm}^{-1}\right)$ & $0.01-0.11$ & $0.010-0.020$ \\
\hline Dissolved Oxygen $(\mathrm{mg} / \mathrm{L})$ & $8.9-10$ & $11.5-15.8$ \\
\hline THMFP $(\mu \mathrm{g} / \mathrm{L})$ & $20-27$ & $25-35$ \\
\hline HAAFP $(\mu \mathrm{g} / \mathrm{L})$ & $5-22$ & $10-25$ \\
\hline
\end{tabular}

The Lake Ontario pilot plant system (Figure 3-1) consisted of four parallel filter trains preceded by ozonation (dose: $1 \mathrm{mg} / \mathrm{L} \mathrm{O}$ : $2 \mathrm{mg} / \mathrm{L} \mathrm{DOC}$, contact time $8 \mathrm{~min}$ ). Ozone was dosed to maintain a residual of between 0.3-0.6 mg/L, which was subsequently quenched using $3 \mathrm{mg} / \mathrm{L}$ sodium bisulphite (SBS) prior to entering the filters. Exhausted GAC (BAC) (Filtrasorb300, $>4$ years of service, $\mathrm{d}_{10}=0.85-1.0, \mathrm{UC}=1.4$ ) and virgin anthracite (effective size, $\mathrm{d}_{10}=0.85, \mathrm{UC}=$ 1.4) were provided by the City of Toronto. Ceralite media with two effective sizes $\left(\mathrm{d}_{10}=1.2\right.$ and $1.0 \mathrm{~mm}$, UC < 1.3) was obtained from Wateropolis, Ohio. Typical properties of the four media types are presented in Table 3-2. All four filters (internal diameter $=7.62 \mathrm{~cm}$; EBCT $=16 \mathrm{~min}$ ) contained $80 \mathrm{~cm}$ of media over $20 \mathrm{~cm}$ of sand $\left(\mathrm{d}_{10}=0.5, \mathrm{UC}=1.8\right)$ and were operated in declining flow rate mode with constant head. Filters were backwashed with their own (unchlorinated) 
effluent to encourage biological growth. The backwash protocol consisted of 30\% fluidization for 2 minutes, followed by 50\% fluidization for 4 minutes, and finally a 30\% fluidization for 4 minutes.

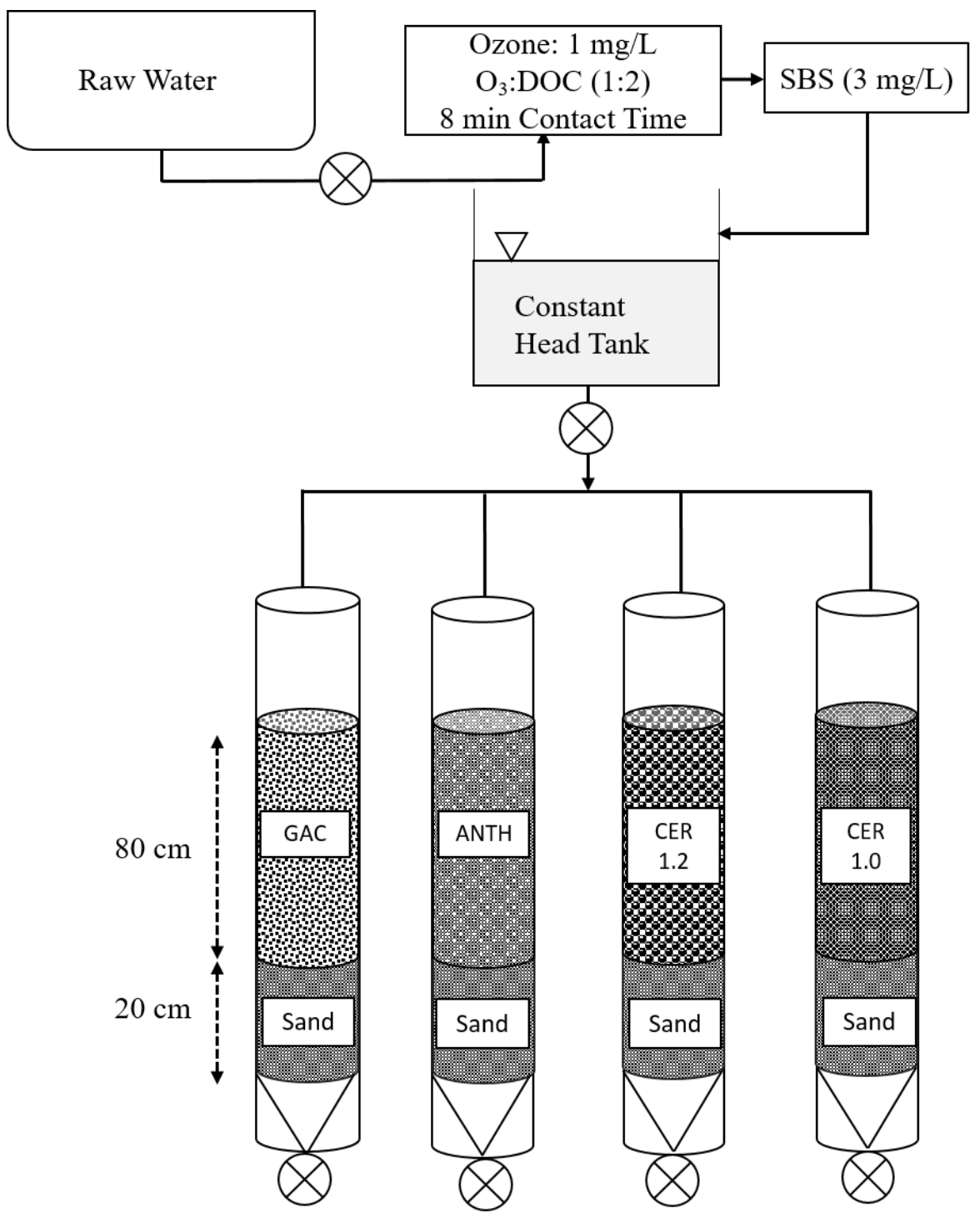

Figure 3-1: Lake Ontario: Pilot plant schematic. Sample points are denoted by $\otimes$

During pilot start-up, filters were backwashed once per week over a period of 9 weeks (October-December). Once the anthracite and GAC filters were acclimated (> $100 \mathrm{ng} \mathrm{ATP/g}$ media), all filters were subsequently backwashed once every two weeks for a period of 35 weeks (January-September). Cold water conditions $\left(6.2 \pm 1.6^{\circ} \mathrm{C}\right)$ were designated as occurring between January and May, with warm water conditions $\left(16.5 \pm 3.3^{\circ} \mathrm{C}\right)$ between June and September. 
Table 3-2: Physical Properties of the Four Media Types: Lake Ontario Pilot

\begin{tabular}{|l|c|c|c|c|}
\hline Parameter & CER 1.2 & CER 1.0 & Anthracite $^{\mathbf{b}}$ & GACc $^{\mathbf{a}}$ \\
\hline Effective Size $(\mathrm{ES}, \mathrm{mm})$ & 1.2 & 1.0 & 0.85 & $0.85-1.0$ \\
\hline Bulk Density $\left(\mathrm{g} / \mathrm{cm}^{3}\right)$ & 0.54 & 0.54 & 1.40 & 0.604 \\
\hline Cost $\left(\mathrm{CAD} / \mathrm{m}^{3}\right)$ & 10.7 & 10.7 & 12 & $55-60$ \\
\hline Surface Area $\left(\mathrm{m}^{2} / \mathrm{m}^{3}\right)$ & 139,278 & 200,560 & 15,404 & Not available \\
\hline Abrasion Resistance & $>2.3$ & $>2.3$ & $>2.7$ & $2-3$ \\
\hline
\end{tabular}

${ }^{\mathrm{a}}$ Wateropolis, 2014; ${ }^{\mathrm{b}}$ Target Products Limited, 2016; ${ }^{\mathrm{c}}$ Calgon Carbon, 2012

The Elgin Area WTP is a conventional water treatment facility consisting of coagulation, flocculation, sedimentation, pre-filter chlorination, filtration, and post-filter chlorination processes. Raw water is pre-chlorinated to achieve a free chlorine residual of $\sim 0.2 \mathrm{mg} / \mathrm{L}$ for zebra mussel control when temperature is greater than $12^{\circ} \mathrm{C}$.

The Elgin area pilot consisted of four parallel filter trains supplied with Elgin Area WTP full-scale filter influent (settled and chlorinated water $\sim 0.35 \mathrm{mg} / \mathrm{L}$ residual); influent water quality parameters are presented in Table 3-1. Each of the four filters (internal diameter $=7.62 \mathrm{~cm}$; EBCT $=16 \mathrm{~min})$ contained $50 \mathrm{~cm}$ of anthracite $\left(\mathrm{d}_{10}=0.85, \mathrm{UC}=1.4\right)$ over $50 \mathrm{~cm}$ of sand $\left(\mathrm{d}_{10}=0.5\right.$, UC $=1.8$ ) and were operated in declining flow rate mode with constant head (Figure 3-2). The filters were backwashed with their own effluent twice a week. Backwash protocol consisted of $30 \%$ fluidization for 2 minutes, followed by 50\% fluidization for 4 minutes, and finally $30 \%$ fluidization for 4 minutes.

During pilot start up, all the filters received settled/chlorinated water for a period of three months (January-March). All filters had similar performance profiles in terms of turbidity, DOC, and DBP precursor removals. In Spring and Summer months (March-August), conventional anthracite filters (CAF1 and $\mathrm{CAF} 2$ ) received settled/chlorinated water while biological anthracite filters (BAF1 and BAF2) received settled/quenched water to allow operation in a biological mode. Therefore, to help encourage biological growth, CAF1 and BAF2 were fed with raw water during fall months (August-November), while no changes were made to the operating conditions of $\mathrm{CAF} 2$ and BAF1, as they served as controls. 

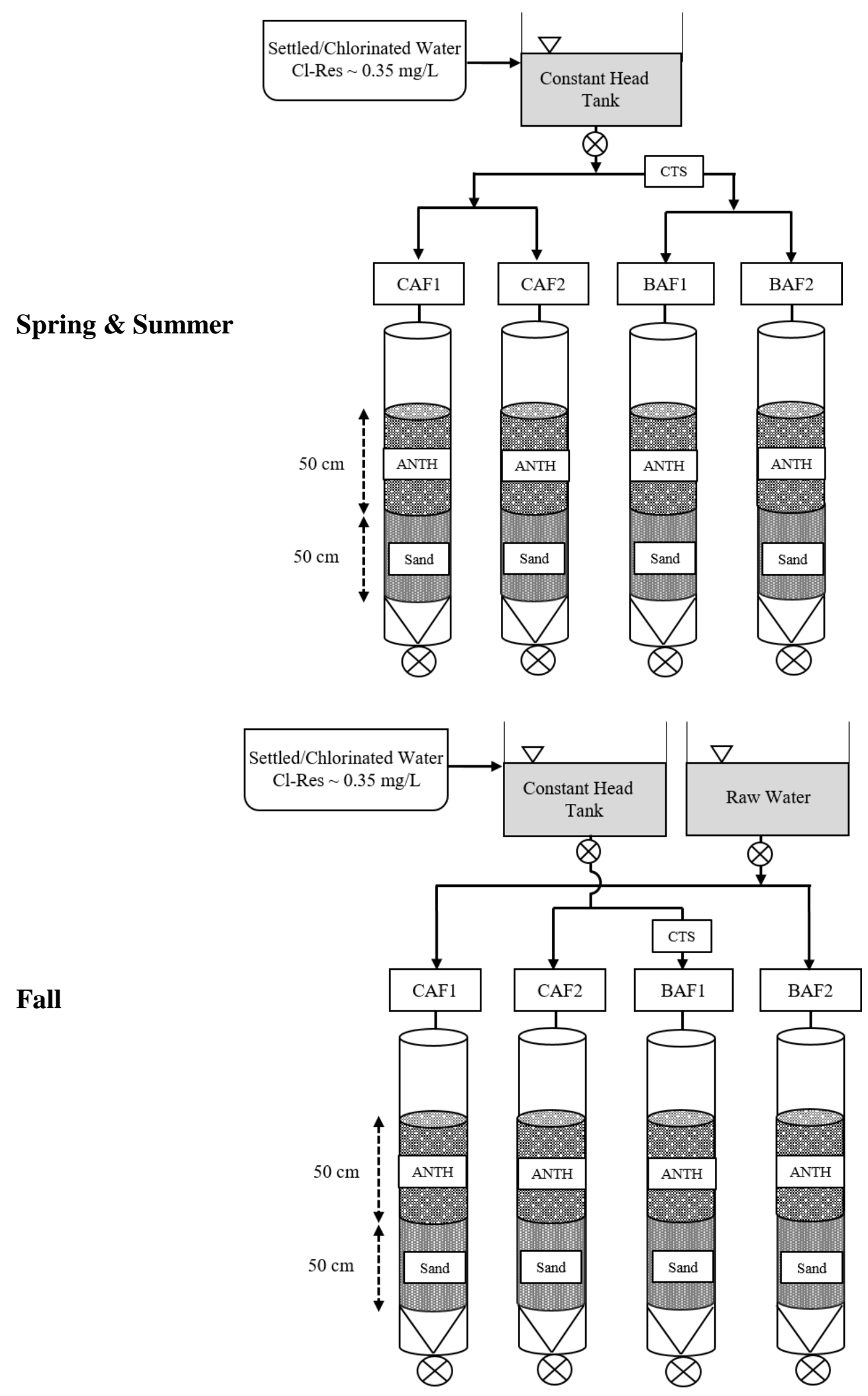

Figure 3-2: Lake Erie: Pilot plant schematic. Two conventional anthracite filters (CAF) and two biological anthracite filters (BAF). Sampling points are denoted by $\otimes$ 


\subsection{Analytical Methods}

\subsubsection{Adenosine Triphosphate (ATP) Analysis}

Adenosine triphosphate (ATP) analysis was conducted using a Luminultra analysis kit (DSA-100C). Media samples were obtained from the top 5-10 cm of the biofilter and analyzed as per the manufacturer's instructions provided in Appendix Table 8-1.

\subsubsection{Dissolved Organic Carbon}

DOC was measured based on standard method 5310 D using an O-I Corporation Model 1010 Analytical TOC Analyzer with a Model 1051 Vial Multi-Sampler (APHA, 2005). Samples were filtered into $40 \mathrm{~mL}$ amber vials through a $0.45 \mu \mathrm{m}$ glass fiber filter, and acidified to $\mathrm{pH} \leq 2$ using concentrated sulfuric acid if samples were not analyzed immediately after preparation. The vials were sealed with Teflon ${ }^{\circledR}-$ lined septum screw caps and stored at $4^{\circ} \mathrm{C}$. All samples were prepared on the day of collection and analyzed within 7 days. DOC concentrations were quantified using anhydrous potassium hydrogen phthalate (KHP) in Milli-Q® water as a calibration solution. A sample calibration curve is presented in Figure 3-3.

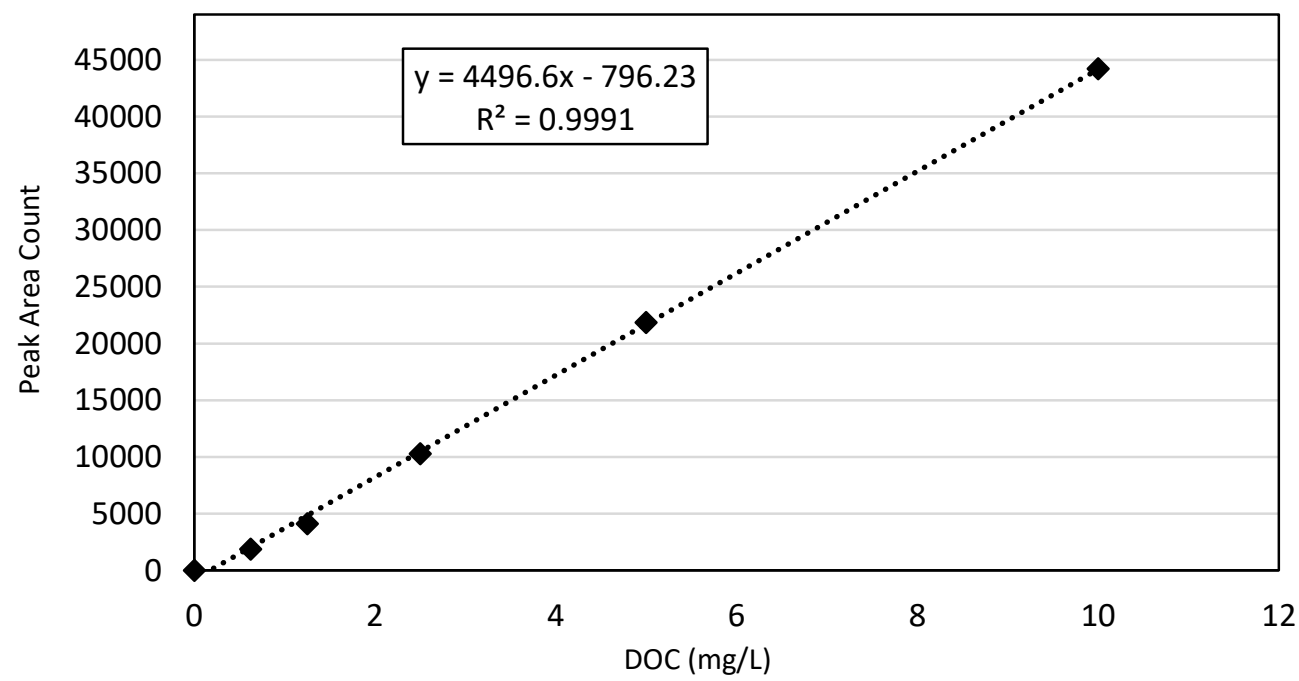

Figure 3-3: Sample Calibration Curve - DOC (April 2016)

The calibration solutions were prepared at a concentration of $10 \mathrm{mg} / \mathrm{L}$ and diluted by the instrument to concentrations of $0,0.625,1.25,2.5$ and $5 \mathrm{mg} / \mathrm{L}$ for a 6-point calibration curve. A $10 \mathrm{mg} / \mathrm{L}$ calibration sample was prepared, diluted and analyzed before each sample set. Check 
standards $(\mathrm{C}=2.5 \mathrm{mg} / \mathrm{L})$ were tested after every 10 samples, and at the end of every sample set. Additionally, a minimum of three blank samples were tested after calibration, and before every check standard sample. The reagent list is presented in Table 3-3, instrument conditions in Table 3-4, and sample preparation and the method outline details are presented in Appendix Table 8-2.

Table 3-3: DOC Analysis Reagents

\begin{tabular}{|l|l|}
\hline Reagent & Supplier and purity \\
\hline Milli-Q® water & Prepared in the laboratory \\
\hline Sulphuric acid, $\mathrm{H}_{2} \mathrm{SO}_{4}$ & VWR International, 98\%+ \\
\hline Sodium persulphate, $\mathrm{Na}_{2}\left(\mathrm{SO}_{4}\right)$ & Sigma Aldrich, 98\%+, anhydrous \\
\hline Potassium hydrogen phthalate (KHP), $\mathrm{C}_{8} \mathrm{H}_{5} \mathrm{KO}_{4}$ & Sigma Aldrich, 98\%+ \\
\hline Phosphoric acid, $\mathrm{H}_{3} \mathrm{PO}_{4}$ & Caledon, >85\% \\
\hline Nitrogen gas, $\mathrm{N}_{2}$ & Praxair, Ultra high purity (UHP) \\
\hline
\end{tabular}

Table 3-4: DOC Analyzer Conditions

\begin{tabular}{|l|l|}
\hline Parameter & Description \\
\hline Acid volume & $200 \mu \mathrm{L}$ of $5 \%$ phosphoric acid \\
\hline Oxidant volume & $1000 \mu \mathrm{L}$ of $100 \mathrm{~g} / \mathrm{L}$ sodium persulphate \\
\hline Sample volume & $15 \mathrm{~mL}$ \\
\hline Rinses per sample & 1 \\
\hline Volume per rinse & $15 \mathrm{~mL}$ \\
\hline Replicates per sample & 3 \\
\hline Reaction time (min:sec) & TIC 2:00; TOC 2:30 \\
\hline Detection time (min:sec) & TIC 2:40; TOC 2:00 \\
\hline Purge gas & Nitrogen \\
\hline Loop size & $5 \mathrm{~mL}$ \\
\hline
\end{tabular}

\subsubsection{UV254}

$\mathrm{UV}_{254}$ is a measure of ultraviolet absorbance at $254 \mathrm{~nm}$ wavelength, and can be used as a surrogate for the concentration of organic materials in a water sample (Kitis et al., 2007). Samples were placed in $1 \mathrm{~cm}$ quartz cell (Hewlett Packard, Mississagua) and measured using a CE 3055 
Single Beam Cecil UV/Visible Spectrophotometer (Cambridge, England). The device was zeroed with Milli-Q ${ }^{\circledR}$ water. The cells were rinsed with Milli-Q ${ }^{\circledR}$ water twice between sampling and rinsed again with the sample water before analysis to minimize contamination.

\subsubsection{Disinfection By-Product (DBP) Formation Test}

To determine the disinfectant dose, the chlorine demand was determined by adding 2 and $3 \mathrm{mg} / \mathrm{L}$ of chlorine to $268 \mathrm{~mL}$ water sample in chlorine-demand-free amber bottles. The bottles were left overnight, and incubated at room temperature $\left(20^{\circ} \mathrm{C} \pm 1.0^{\circ} \mathrm{C}\right)$ for 24 hours. The difference between the initial and the final chlorine concentration was calculated as the chlorine demand. After the chlorine demand was determined, new samples were collected in chlorinedemand-free amber bottles. The samples were chlorinated to achieve a target residual of $1 \pm 0.4$ $\mathrm{mg} / \mathrm{L}$ after 24 hours. The residual chlorine was measured after 24 hours, and if it was correct, each sample was quenched with $20 \mathrm{mg}$ (two scoops) of L-ascorbic acid. The bottles were then acidified to $\mathrm{pH} 2$ with $\mathrm{H}_{2} \mathrm{SO}_{4}$ and stored in the dark at $4^{\circ} \mathrm{C}$ until extraction.

\subsubsection{Trihalomethanes (THMs)}

Trihalomethane analysis involved quantification of the following four compounds: chloroform (trichloromethane; TCM), bromodichloromethane (BDCM), dibromochloromethane (DBCM), and bromoform (tribromomethane; TBM). A liquid-liquid extraction with gas chromatography was performed based on Standard Method 6232 B (APHA, 2012). The analysis was conducted at the drinking water research group's laboratory (University of Toronto, Ontario) using a Hewlett Packard 5890 Series II Plus gas chromatograph (Mississauga, Ontario) equipped with an electron capture detector (GC-ECD) and a DB 5.625 capillary column (Agilent 30 Technologies Canada Inc., Mississauga, Ontario). A THM stock solution (2000 $\mu \mathrm{g} / \mathrm{mL})$ was used to prepare an intermediate stock solution $(20 \mathrm{mg} / \mathrm{L})$. This stock was used to prepare calibration standards of $0,5,10,20,40,60,100,150$, and $200 \mu \mathrm{g} / \mathrm{L}$. A sample calibration curve is presented in Figure 3-4. The required reagents (Table 3-5) and the instrument conditions (Table 3-6) are presented below. The method outline is presented in Appendix Table 8-3. 


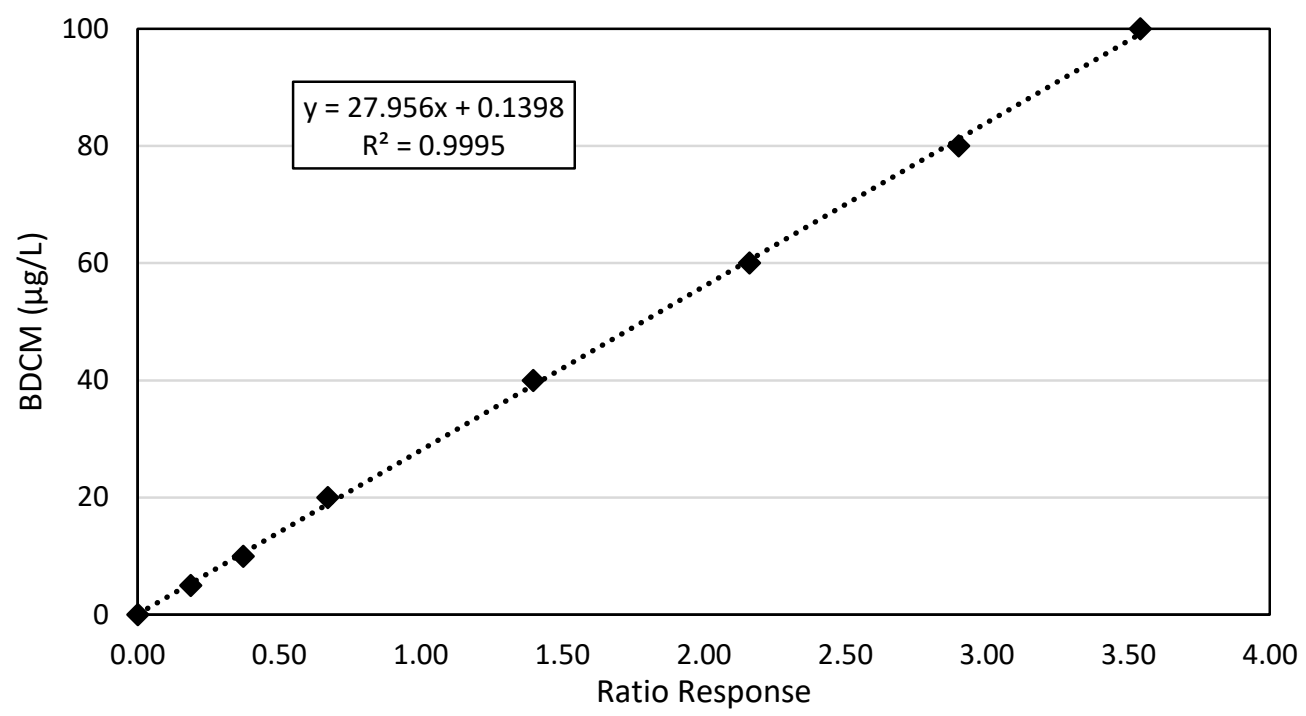

Figure 3-4: Sample BDCM Calibration Curve (February 2016)

Table 3-5: THM Reagent Compounds

\begin{tabular}{|l|l|}
\hline Reagent & Source \\
\hline Milli-Q® water & Prepared in the laboratory \\
\hline $\begin{array}{l}\text { Concentrated trihalomethane stock for } \\
\text { calibration }\end{array}$ & $\begin{array}{l}\text { Supelco, } 2000 \mu \mathrm{g} / \mathrm{mL} \text { in methanol } \\
(48140-\mathrm{U})\end{array}$ \\
\hline Sodium sulphate $\left[\mathrm{Na}_{2} \mathrm{SO}_{4}\right]$ & Sigma Aldrich, ACS Grade \\
\hline Methyl-tert-butyl-ether $(\mathrm{MTBE})$ & Fluka, $>99.8 \%$ \\
\hline
\end{tabular}

Table 3-6: THM Instrument Conditions

\begin{tabular}{|l|l|}
\hline Parameter & Description \\
\hline Injector Temperature & $200^{\circ} \mathrm{C}$ \\
\hline Detector Temperature & $300^{\circ} \mathrm{C}$ \\
\hline & $40^{\circ} \mathrm{C}$ for $4.0 \mathrm{~min}$ \\
Temperature Program & $4^{\circ} \mathrm{C} / \mathrm{min}$ temperature ramp to $95^{\circ} \mathrm{C}$ \\
& $60^{\circ} \mathrm{C} / \mathrm{min}$ temperature ramp to $200^{\circ} \mathrm{C}$ \\
\hline Carrier Gas & Helium \\
\hline Flow Rate & $1.2 \mathrm{~mL} / \mathrm{min}$ at $35^{\circ} \mathrm{C}$ \\
\hline
\end{tabular}




\subsubsection{Haloacetic Acids (HAAs)}

The analysis of haloacetic acids (HAAs) involved quantification of the following 9 compounds: monochloroacetic acid (MCAA), monobromoacetic acid (MBAA), dichloroacetic acid (DCAA), trichloroacetic acid (TCAA), bromochloroacetic acid (BCAA), dibromoacetic acid (DBAA), bromodichloroacetic acid (BDCAA), dibromochloroacetic acid (DBCAA), and tribromoacetic acid (TBAA). The extraction was conducted using a liquid-liquid extraction based on Standard Method 6251 B (APHA, 2012); reagent list is presented in Table 3-7. The analysis was completed at the drinking water research group's laboratory (University of Toronto, Ontario) using a Hewlett Packard 5890 Series II Plus gas chromatograph (Mississauga, Ontario) paired with an electron capture detector (GC-ECD) and a DB 5.625 capillary column (Agilent Technologies Canada Inc., Mississauga, Ontario). The instrument conditions are presented in Table 3-8, and the method outline is presented in Appendix Table 8-4. A sample calibration curve is presented in Figure 3-5.

Table 3-7: HAA Reagent Compounds

\begin{tabular}{|l|l|}
\hline Reagent & Source \\
\hline $\begin{array}{l}\text { Diethyl ether } \\
{\left[\mathrm{C}_{2} \mathrm{H}_{5} \mathrm{OCH}_{2} \mathrm{CH}_{2} \mathrm{OCH}_{2} \mathrm{CH}_{2} \mathrm{OH}\right]}\end{array}$ & Sigma Aldrich, 99+\% \\
\hline Milli-Q ${ }^{\circledR}$ water & Prepared in the laboratory \\
\hline $\begin{array}{l}\text { N-Methyl-N-nitroso-p-toluene sulfonamide } \\
(\text { Diazald })\left[\mathrm{CH}_{3} \mathrm{C}_{6} \mathrm{H}_{4} \mathrm{SO}_{2} \mathrm{~N}\left(\mathrm{CH}_{3}\right) \mathrm{NO}\right]\end{array}$ & Sigma Aldrich, 99+\% \\
\hline Potassium Hydroxide $(\mathrm{KOH})$ & BDH, 85.0+\%, ACD Grade \\
\hline Sulphuric acid $\left[\mathrm{H}_{2} \mathrm{SO}_{4}\right]$ & E.M. Science, 98+\% \\
\hline Haloacetic acids concentrated stock & EPA 552.2 Acids Calibration Mix in MTBE \\
\hline Sodium sulphate $\left[\mathrm{Na}_{2} \mathrm{SO}{ }_{4}\right]$ & Sigma Aldrich, ACS Grade \\
\hline Methyl-tert-butyl-ether (MTBE) & Sigma Aldrich, >99.8\% \\
\hline Methanol (MeOH) & Sigma Aldrich, >99.8\% \\
\hline
\end{tabular}


Table 3-8: HAA Instrument Conditions

\begin{tabular}{|l|l|}
\hline Parameter & Description \\
\hline Injector Temperature & $200^{\circ} \mathrm{C}$ \\
\hline Detector Temperature & $300^{\circ} \mathrm{C}$ \\
\hline & $35^{\circ} \mathrm{C}$ for $10.0 \mathrm{~min}$ \\
& $2.5^{\circ} \mathrm{C} /$ min temperature ramp to $65^{\circ} \mathrm{C}$ \\
& $10^{\circ} \mathrm{C} / \mathrm{min}$ temperature ramp to $85^{\circ} \mathrm{C}$ \\
& $20^{\circ} \mathrm{C} / \mathrm{min}$ temperature ramp to $205^{\circ} \mathrm{C}$, hold for 7 minutes \\
\hline Carrier Gas & Helium \\
\hline Flow Rate & $1.2 \mathrm{~mL} / \mathrm{min}$ at $35^{\circ} \mathrm{C}$ \\
\hline
\end{tabular}

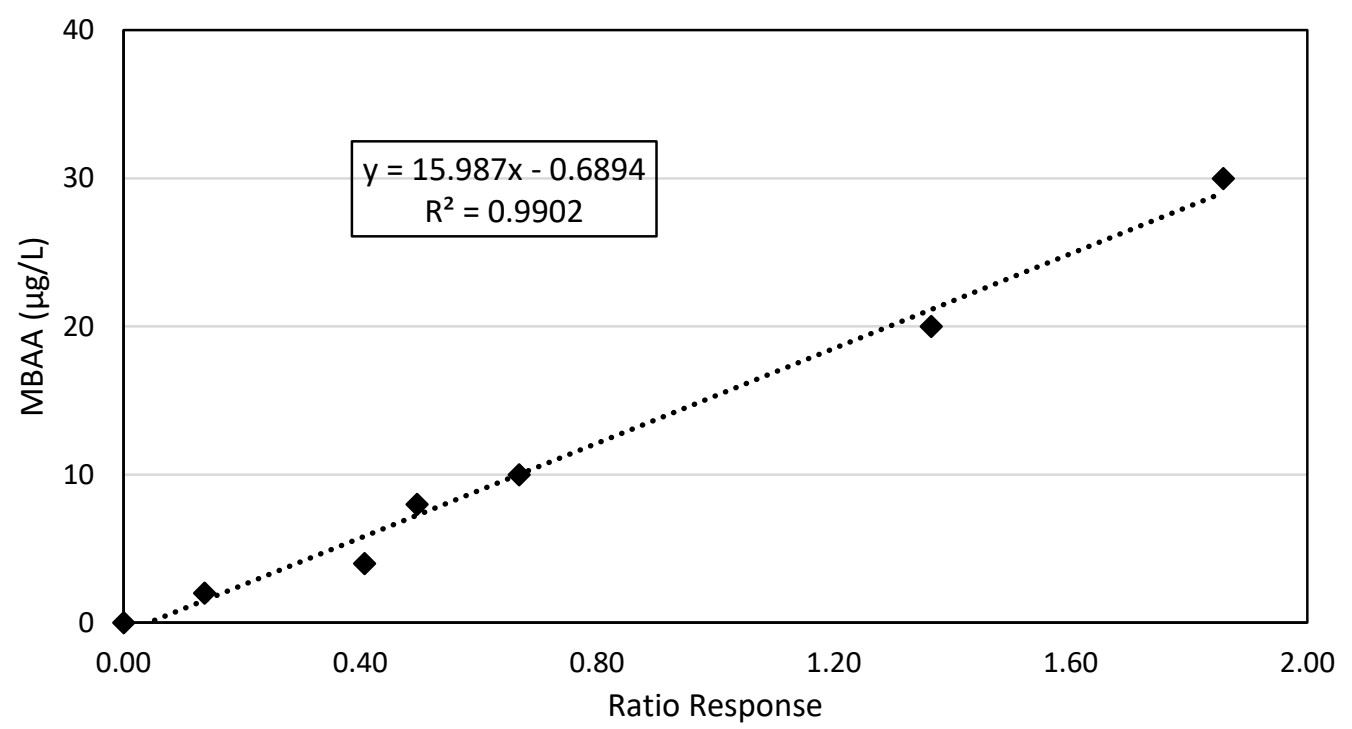

Figure 3-5: Sample HAA Calibration Curve (March 2016)

\subsubsection{Esterase and Laccase Enzyme Activity}

Media samples were stored at $4^{\circ} \mathrm{C}$, dissolved in tris buffer, sonicated for 15 minutes to extract the enzymes, and analyzed within 8 hours of collection. Microbial enzyme activity of two specific enzymes, esterase and laccase, was assessed using their substrate analogues, 4methylumbelliferone acetate (4-MUB-acetate) and L-3,4-dihydroxyphenlaniline (L-DOPA), respectively. The method outline is presented in Appendix Table 8-5. For laccase activity, 200 $\mu 1$ of media extract was incubated with $25 \mu \mathrm{l}$ of L-DOPA substrate $(20 \mathrm{mM}, \mathrm{pH}=8)$ in a 96 -well 
plate and assayed in quadruplicate. Absorbance was measured at $460 \mathrm{~nm}$ every 15 minutes for a minimum of 36 hours using a Sunrise ${ }^{\mathrm{TM}}$ absorbance plate reader (Tecan Group Ltd., Männedorf, Switzerland) equipped with XFlouro4 software V 4.5.1 for data reduction. The laccase substrate absorbance, L-DOPA, was converted into a concentration using a molar extinction coefficient of $7.9 \mu \mathrm{mol}$ (Lautenschlager et al., 2014). For esterase activity, $200 \mu \mathrm{M}$ substrate solutions for 4methylumbelliferone (4 MUB) and 4 MUB-acetate in dimethyl sulfoxide (DMSO) were prepared. A calibration curve ranging from 0 to $100 \mu \mathrm{M}$ was obtained using $200 \mu \mathrm{M}$ solution of $4 \mathrm{MUB}$. $1.6 \mathrm{~mL}$ media extract was incubated with $0.4 \mathrm{~mL}$ MUB acetate and assayed in triplicate. The fluorescence of each sample was measured $(0,2,5,10,15,20,25,30,45$, and 60 minutes) using a Cary Eclipse Luminescence Spectrometer G9800A (Agilent Technologies Canada Inc., Mulgrave, Victoria, Australia) at an excitation wavelength of $370 \mathrm{~nm}$ and an emission wavelength of $445 \mathrm{~nm}$. Additionally, absorbance values at $370 \mathrm{~nm}$ and $445 \mathrm{~nm}$ were measured for absorbance correction using a CE 3055 Single Beam Cecil UV/Visible Spectrophotometer (Cambridge, England). Fluorescence values were corrected for absorbance and converted to a 4 MUB concentration using the calibration curve. The reagent list is presented in Table 3-9.

Table 3-9: Enzyme Activity Reagent Compounds

\begin{tabular}{|l|l|}
\hline Reagent & Source \\
\hline Milli-Q® water & Prepared in the laboratory \\
\hline 4-methylumbelliferone (4-MUB) & Sigma Aldrich, ACS Grade \\
\hline $\begin{array}{l}\text { 4-methylumbelliferone acetate } \\
\text { (4-MUB-acetate) }\end{array}$ & Sigma Aldrich, ACS Grade \\
\hline $\begin{array}{l}\text { L-3,4-dihydroxyphenlaniline } \\
\text { L-Dopa) }\end{array}$ & Sigma Aldrich, $\geq 98 \%$ (TLC) \\
\hline Dimethyl sulfoxide (DMSO) & EBPI, 10\% \\
\hline Tris Buffer & Bioshop, 99.9\% \\
\hline
\end{tabular}

\subsubsection{Scanning Electron Microscopy (SEM) Imaging}

Scanning electron microscope (JEOL JSM6610-Lv SEM, JEOL USA, Inc., Peabody, MA) and energy dispersive X-ray spectrometer (EDX) were used to further characterize surface 
morphology and biological attachment on filter media (Department of Earth Sciences, University of Toronto). Biological filter media samples were fixed (Appendix Table 8-6) and examined for biofilm growth at multiple magnification levels ranging from $1000 \mathrm{X}$ to $10,000 \mathrm{X}$. The media sample surface under SEM was irradiated with high-energy electron bean in a raster scan pattern, generating signals to form 3-dimensional, high-resolution images. The sample surface also emits $\mathrm{X}$-rays that can be further analyzed to gain qualitative and quantitate information regarding elemental composition of the specimen. It is necessary that the media sample is evenly coated with a thin layer of gold (10-20nm) to make it electrically conducting.

\subsubsection{Dissolved Inorganic Elements (Manganese and Iron)}

Samples for dissolved manganese and iron analysis were prepared by filtering $10 \mathrm{~mL}$ samples through $0.45-\mu \mathrm{m}$ syringe filters and preserved by adding $0.25 \%(\mathrm{v} / \mathrm{v})$ nitric acid to $\mathrm{pH}<$ 2 according to Standard Method 3030 B (APHA, 2012). All samples were stored at $4^{\circ} \mathrm{C}$ until analysis. Dissolved manganese and iron concentrations in the samples were determined using inductively coupled plasma optical emission spectrometry (ICP-OES) with an Optima 7300 DV ICP-OES 20 spectrometer (PerkinElmer, Waltham, MA) at the Analytical Laboratory for Environmental Science Research \& Training (ANALEST) at the Department of Chemistry (University of Toronto). Method detection limit for manganese and iron was $10 \mu \mathrm{g} / \mathrm{L}$.

\subsection{Statistical Analysis}

A two-tailed paired test (95\% significance level) was used to compare the performance of two different treatment, while a single-tailed test ( $95 \%$ significance level) was used to compare if a particular treatment is able to remove the analyte of interest from the influent/raw water as described by McKie et al. (2015). Reported p-values indicate the level at which the difference between two treatments was statistically significant. 


\section{Comparative Assessment of Ceramic Media for Drinking Water Biofiltration}

\subsection{Introduction}

Natural organic matter (NOM) represents carbon-based compounds in source waters derived from decomposition, algal metabolism, and anthropogenic activity (Yavich et al., 2004). In the presence of a disinfectant, NOM will react to form disinfection by-products (DBPs) (Bose and Reckhow, 2007). Due to the impact of NOM on finished water quality, drinking water utilities strive to optimize their treatment processes to maximize organic removal. Biofiltration is a natural, cost-effective process that allows indigenous microbial community to attach and colonize the surface of granular media resulting in the biodegradation of soluble organic constituents (Zhu et al., 2010). The coupling of ozonation with biofiltration to oxidize recalcitrant organics is common practice for maximizing NOM and DBPs precursor removal (Delatolla et al., 2015). Biofiltration implementation and operation in the drinking water industry has begun shifting from a passive to an active approach that targets multiple water quality objectives including organic and inorganic removal, while maintaining acceptable hydraulic capabilities (Lauderdale et al., 2012). While several studies have examined the impact of enhancement strategies, including nutrient enrichment, peroxide addition, and in-line coagulation on biofiltration performance (Azzeh et al., 2015; Lauderdale et al., 2012; McKie et al., 2015), the impact of media type is also a critical design consideration.

Previous studies have shown that media type can play an important role in enhancing biological activity resulting in higher degradation of organic constituents (Emelko et al., 2006; Liu et al., 2001). Media selection depends on variety of factors including, uniformity coefficient (UC), effective size (ES), surface roughness, and density. It is also dictated by specific treatment objectives such as removal of organics or extending filter run time. The most commonly used dual-media configurations include anthracite/sand and granular activated carbon (GAC)/sand (Pharand et al., 2014). While alternative media such as crushed apricot stones (Aksoğan et al., 2004), polyurethane foam filter (Biswas et al., 2003), crushed glass, pumice (Kitis et al., 2007) and compressible rubber granules (Valdes and Liang, 2006) have also been investigated, direct comparison to conventional media is lacking. The low density of ceramic media allows for shorter 
backwash times with lower energy/water requirements. In addition, the higher effective size can potentially reduce headloss and improve filter run times.

This pilot-scale study evaluated the performance of two different effective sizes (1.0 and $1.2 \mathrm{~mm}$ ) of ceramic media in comparison to conventional media (anthracite and GAC). Biological concentration and activity on the filter media was quantified using ATP and enzyme (esterase and laccase) assays, respectively. A qualitative assessment was also performed using scanning electron microscopy (SEM) images to visually compare surface morphology and biofilm attachment on the filter media. Performance in terms of DOC, turbidity, headloss, $\mathrm{UV}_{254}$, and DBP formation potential was also examined.

\subsection{Materials and Methods}

\subsubsection{Pilot Plant Configuration}

Pilot-scale biofiltration studies were carried out at the RC Harris Water Treatment Plant (WTP) located on Lake Ontario in Toronto, Canada. A schematic of the pilot plant is presented in Figure 3-1. Influent DOC, turbidity, temperature, and $\mathrm{pH}$ values ranged between 1.8-2.3 mg/L, 0.2-1 NTU, 4.8-21.6 $6^{\circ}$, and 7.2-7.9, respectively.

The pilot consisted of four parallel filter trains preceded by ozonation $\left(1 \mathrm{mg} / \mathrm{L} \mathrm{O}_{3}: 2 \mathrm{mg} / \mathrm{L}\right.$ DOC, contact time $8 \mathrm{~min}$ ). Ozone was dosed to maintain a residual of between $0.3-0.6 \mathrm{mg} / \mathrm{L}$, which was subsequently quenched using $3 \mathrm{mg} / \mathrm{L}$ sodium bisulphite (SBS) prior to entering the filters. Exhausted GAC (Filtrasorb 300, >4 years of service, $\mathrm{d}_{10}=0.85-1.0, \mathrm{UC}=1.4$ ) and virgin anthracite $\left(\mathrm{d}_{10}=0.85, \mathrm{UC}=1.4\right)$ were provided by the City of Toronto. Ceralite media with two effective sizes $\left(\mathrm{d}_{10}=1.2\right.$ and $\left.1.0 \mathrm{~mm}, \mathrm{UC}<1.3\right)$ was obtained from Wateropolis, Ohio. All four filters (internal diameter $=7.62 \mathrm{~cm}$; EBCT $=16 \mathrm{~min}$ ) contained $80 \mathrm{~cm}$ of media over $20 \mathrm{~cm}$ of sand $\left(\mathrm{d}_{10}=0.5, \mathrm{UC}=1.8\right)$ and were operated in declining flow rate mode with constant head. Filters were backwashed with their own unchlorinated effluent to encourage biological growth. The backwash protocol consisted of $30 \%$ fluidization for 2 minutes, followed by $50 \%$ fluidization for 4 minutes, and finally a $30 \%$ fluidization for 4 minutes.

During the pilot start-up, filters were backwashed once per week over a period of 9 weeks (October-December). Once the anthracite and GAC filters were acclimated (> $100 \mathrm{ng}$ ATP/g media), all filters were subsequently backwashed once every two weeks for a period of 35 weeks 
(January-September). Cold water conditions $\left(6.2 \pm 1.6^{\circ} \mathrm{C}\right)$ were designated as occurring between January and May, with warm water conditions $\left(16.5 \pm 3.3^{\circ} \mathrm{C}\right)$ between June and September.

\subsubsection{Analytical Methods}

Dissolved organic carbon (DOC) was measured using a persulfate wet oxidation method as described in Standard Method 5310 D (APHA, 2012) with an O-I Corporation Model 1010 TOC Analyzer (College Station, Texas, USA). A CE 3055 Single Beam Cecil UV/Visible Spectrophotometer (Cambridge, England) with $1 \mathrm{~cm}$ quartz crystal cuvette (Hewlett Packard, Mississauga) was used for measuring ultraviolet absorbance at $254 \mathrm{~nm}$ (UV254).

Biological filter media samples were collected from the top 5-10 cm layer of the biofilters. Biomass on the filter media surface was measured as adenosine triphosphate normalized to the weight of the filter media (ng ATP/g media) using a LuminUltra Deposit Surface Analysis Kit (DSA-100C, Fredricton, NB) as per the manufacturer's instructions. Media samples were stored at $4^{\circ} \mathrm{C}$, dissolved in tris buffer, sonicated for 15 minutes to extract the enzymes, and analyzed within 8 hours of collection. Microbial enzyme activity of two specific enzymes, esterase and laccase, was assessed using their substrate analogues, 4-methylumbelliferone acetate (4-MUBacetate) and L-3,4-dihydroxyphenlaniline (L-DOPA), respectively. For laccase activity, $200 \mu 1$ of media extract was incubated with $25 \mu \mathrm{l}$ of L-DOPA substrate $(20 \mathrm{mM}, \mathrm{pH}=8)$ in a 96-well plate and assayed in quadruplicate. Absorbance was measured at $460 \mathrm{~nm}$ every 15 minutes for a minimum of 36 hours using a Sunrise ${ }^{\mathrm{TM}}$ absorbance plate reader (Tecan Group Ltd., Männedorf, Switzerland) equipped with XFlouro4 software V 4.5.1 for data reduction. The laccase substrate absorbance, L-DOPA, was converted into a concentration using a molar extinction coefficient of $7.9 \mu \mathrm{mol}$ (Lautenschlager et al., 2014). For esterase activity, $200 \mu \mathrm{M}$ substrate solutions for 4methylumbelliferone (4 MUB) and 4 MUB-acetate in dimethyl sulfoxide (DMSO) were prepared. A calibration curve ranging from 0 to $100 \mu \mathrm{M}$ was obtained using $200 \mu \mathrm{M}$ solution of $4 \mathrm{MUB}$. $1.6 \mathrm{~mL}$ media extract was incubated with $0.4 \mathrm{~mL}$ MUB acetate and assayed in triplicate. The fluorescence of each sample was measured $(0,2,5,10,15,20,25,30,45$, and 60 minutes) using a Cary Eclipse Luminescence Spectrometer G9800A (Agilent Technologies Canada Inc., Mulgrave, Victoria, Australia) at an excitation wavelength of $370 \mathrm{~nm}$ and an emission wavelength of $445 \mathrm{~nm}$. Additionally, absorbance values at $370 \mathrm{~nm}$ and $445 \mathrm{~nm}$ were measured for absorbance 
correction using a CE 3055 Single Beam Cecil UV/Visible Spectrophotometer (Cambridge, England). Fluorescence values were corrected for absorbance and converted to 4 MUB concentration using the calibration curve.

A scanning electron microscope (JEOL JSM6610-Lv SEM, JEOL USA, Inc., Peabody, MA) and energy dispersive X-ray spectrometer (EDX) were used to further characterize surface morphology and biological attachment on filter media (Department of Earth Sciences, University of Toronto). Filter media samples were examined for biofilm growth at multiple magnification levels ranging from 1000X to 10,000X.

For DBP analyses, water samples were chlorinated in duplicate to achieve a free chlorine target residual of $1.5 \pm 0.5 \mathrm{mg} / \mathrm{L}$ after $24 \pm 2$ hours at $20^{\circ} \mathrm{C}$, where $\mathrm{pH}$ matched that observed at full-scale (APHA, 2012). Free chlorine residuals were measured as per Standard Methods 4500Cl G (APHA, 2012), and quenched with L-ascorbic acid. Liquid-liquid extraction and gas chromatography were used to analyze four THMs (chloroform, bromodichloromethane, dibromochloromethane, and bromoform) and nine HAAs (monochloroacetic acid, monobromoacetic acid, dichloroacetic acid, trichloroacetic acid, bromochloroacetic acid, dibromoacetic acid, bromodichloroacetic acid, dibromochloroacetic acid, and tribromoacetic acid) as per Standard Method 6232 B and 6251, respectively (APHA, 2012). A Hewlett Packard 5890 Series II Plus Gas Chromatograph (Mississauga, Ontario, Canada) equipped with an electron capture detector (GCECD) and a DB 5.625 capillary column (Agilent Technologies Canada Inc., Mississauga, Ontario, Canada) was used for both THM and HAA analysis.

\subsubsection{Statistical Methods}

A two-tailed paired test (95\% significance level) was used to compare the performance of different filter media as described by McKie et al. (2015). Reported p-values indicate the level at which the difference between two treatments would be statistically significant.

\subsection{Results and Discussion}

\subsubsection{Biological Characterization of the Filter Media}




\section{Adenosine Triphosphate (ATP)}

ATP concentrations were used as a surrogate to quantify the viable biomass on filter media (Velten et al., 2011). Acclimation time to establish a biofilm is a useful indicator of attachment potential (Dussert and Tramposch, 1997). Pharand et al. (2014) reviewed 16 published studies and established a benchmark concentration of $100 \mathrm{ng} \mathrm{ATP} / \mathrm{cm}^{3}$ media to define an active, acclimated biofilter. ATP acclimation for the four media types over a calendar year of pilot-plant operation is shown in Figure 4-1. The GAC media was deemed as biological (> $100 \mathrm{ng}$ ATP/g media) within 45 days of filter operation, which is on the lower range of the reported acclimation time for GAC filters (2-4 months) as by others (Seredyńska-Sobecka et al., 2006; Servais, 1994). Pre-ozonation as applied in this study has been shown to accelerate biomass formation and reduce acclimation time (Ohkouchi et al., 2011).

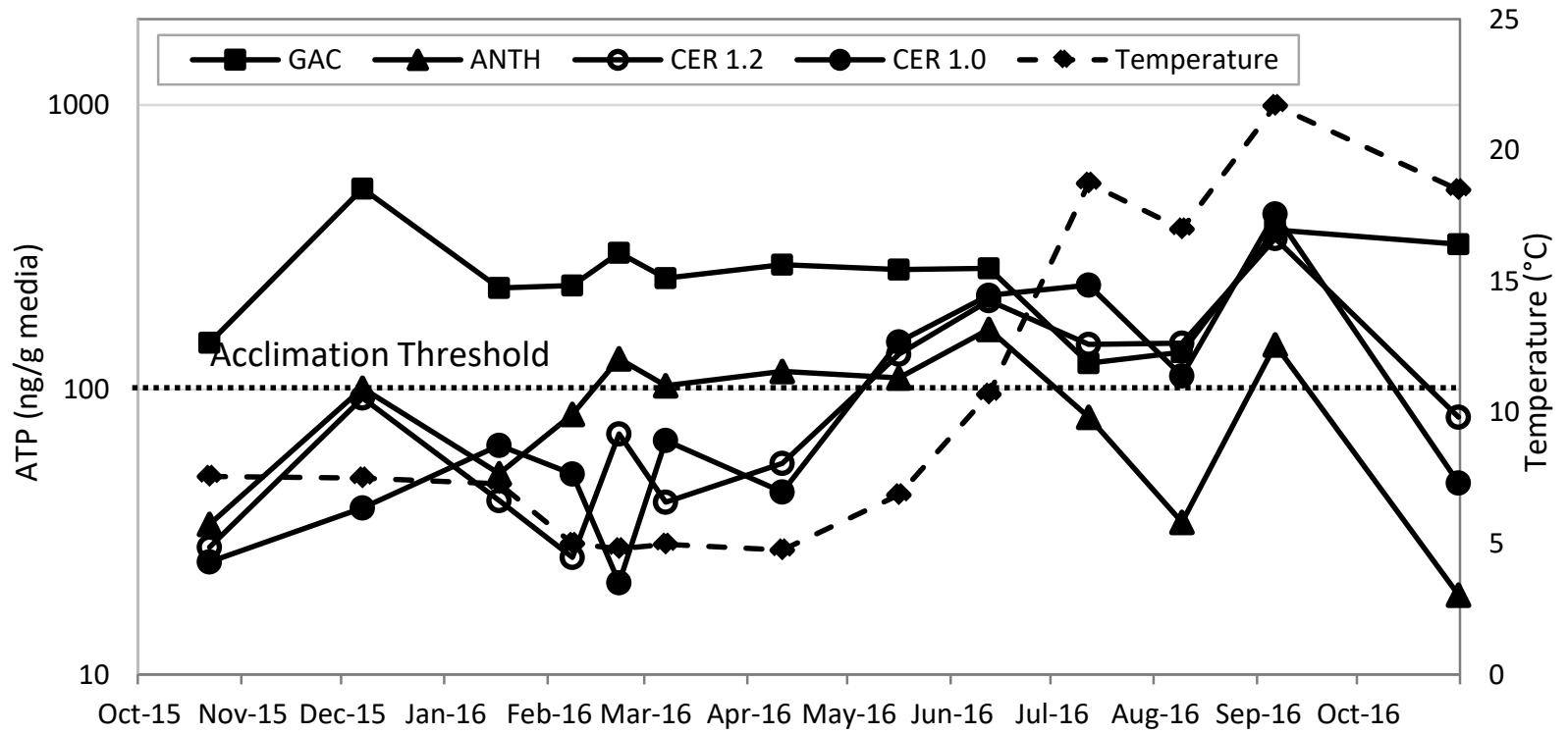

Figure 4-1: ATP concentrations (ng ATP/g) for four different media types (GAC, anthracite, Ceralite $1.2 \mathrm{~mm}$, and Ceralite $1.0 \mathrm{~mm}$ ).

Once acclimated, anthracite ATP values remained steady at $107 \pm 38 \mathrm{ng}$ ATP/g media (Figure 4-1). These values are lower than those for full-scale anthracite-sand filters ATP values (205-528 ng/g media; TOC $=2.7-3.2 \mathrm{mg} / \mathrm{L}$ ) as reported in the literature (Stoddart and Gagnon, 2015) likely due to variations with respect to inherent source water characteristics including assimilable organic carbon or nutrient concentrations (Korotta-Gamage and Sathasivan, 2017). 
The GAC filter ( $246 \pm 75 \mathrm{ng}$ ATP/g media) had significantly higher ATP values $(\mathrm{p}<0.05)$ when compared to anthracite filter due to higher surface roughness and stronger biomass attachment potential (Dussert and Tramposch, 1997).

Mercury intrusion testing of ceramic media $\left(139,278 \mathrm{~m}^{2} / \mathrm{m}^{3}\right)$ has shown a ten-fold higher pore surface area $>0.5$ microns when compared to sand $\left(12,164 \mathrm{~m}^{2} / \mathrm{m}^{3}\right)$ and anthracite $(15,404$ $\mathrm{m}^{2} / \mathrm{m}^{3}$ ) (French, 2012). However, the acclimation time for ceramic media (6-7 months) was approximately 4-5 months longer than for GAC and anthracite (Figure 4-1). Once acclimated, ATP values for CER 1.2 (208.8 $\pm 38 \mathrm{ng}$ ATP/g media) and CER 1.0 (243.7 $\pm 126 \mathrm{ng}$ ATP/g media) matched GAC and were significantly $(\mathrm{p}=0.05)$ higher when compared to anthracite. No relationship between temperature and ATP values was elucidated; Pharand et al. (2014) speculated that consistent viable biomass can be retained on a given filter while organic degradation rates decrease with temperature.

\section{Surface Electron Microscopy (SEM)}

Magnified images of ceramic media revealed highly porous structure with increased surface area when compared to anthracite and GAC (Figure 4-2). Despite its porous structure, a very thin layer of biofilm was observed on the ceramic media surfaces (Figure 4-2-C,D), while a thick webbed gelatinous biofilm was attached to the GAC surface (Figure 4-2-A). While it is difficult to elucidate the reason for microbial attachment preference on GAC from a qualitative perspective, differences in biofilm growth may be a function of the rugged topography of GAC when compared to the smooth texture of ceramic media (Figure 4-2). Percival et al. (1999) have previously reported that increased surface roughness can enhance biofilm attachment and subsequent colonization. The anthracite surface with infused pits ranging from 2-10 $\mu \mathrm{m}$ in diameter supported little biofilm, as evident from the thin layer with sparsely populated cocci and road shaped bacteria (Figure 4-2-B).

EDX results are presented for each SEM image to compare the elemental composition of the biofilm (Figure 4-2). GAC and anthracite biofilms were predominantly carbon (>65\%), oxygen ( 15-20\%), with other trace elements including aluminum (3\%), silicon (2.5\%), and sodium $(0.75 \%)$, whereas the ceramic media biofilm was mostly silicon (22\%), aluminum (19\%), and oxygen (45\%) with trace amounts of magnesium (1.5\%), iron (3\%), and potassium (0.9\%). 
As such, varying biofilm composition may reflect bacterial colonization preference based distinct physical and chemical properties of a given media.
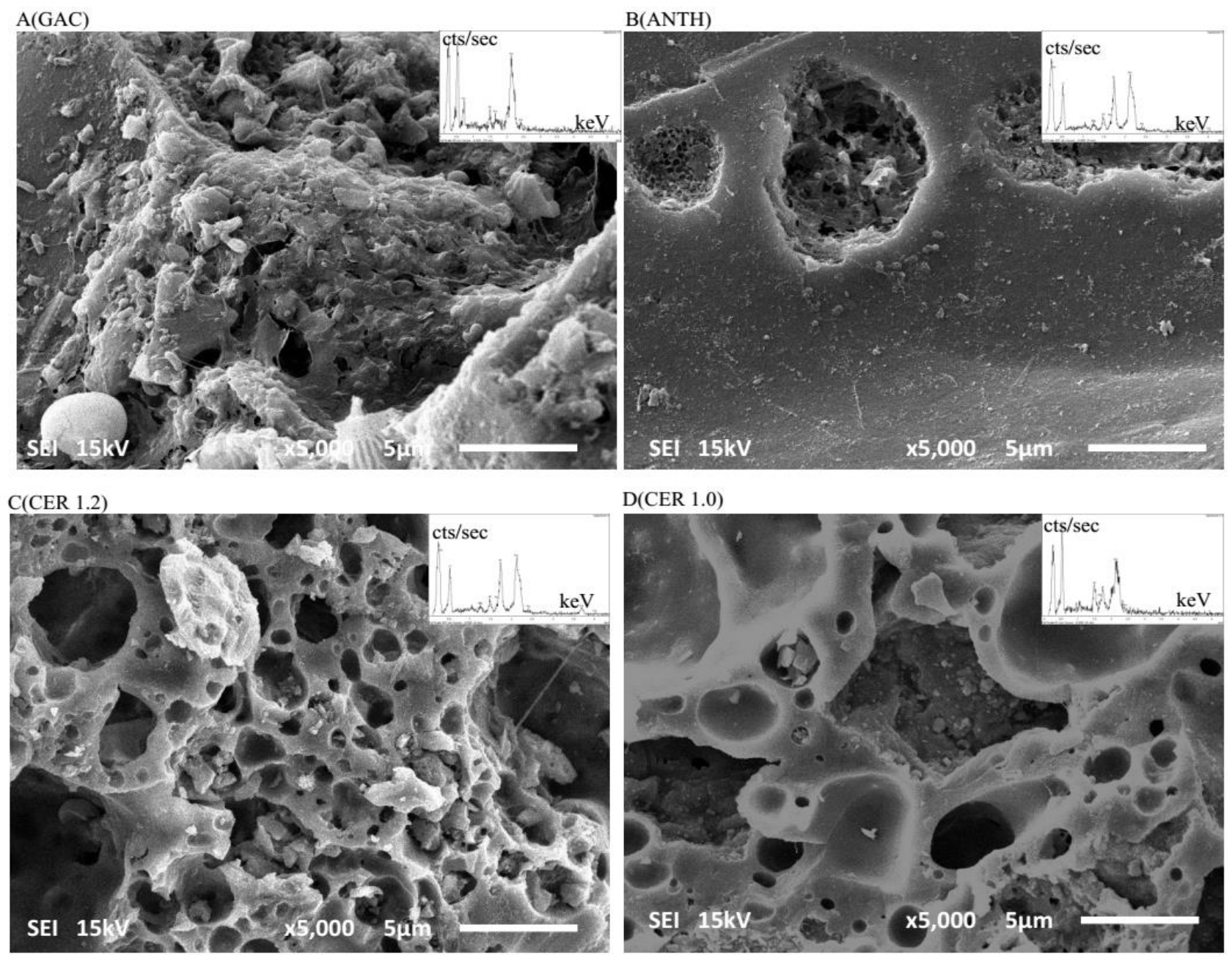

Figure 4-2: SEM micrographs of different filter media at 5000X magnification level: A (GAC), $\mathrm{B}$ (anthracite), C (Ceralite $1.2 \mathrm{~mm}$ ), D (Ceralite 1.0mm). EDX spectrum for each biofilm is displayed on the top right corner (count rate cts/sec versus energy, $\mathrm{keV}$ ).

GAC had the highest biofilm surface coverage when compared to anthracite and ceramic media. SEM images of the GAC media showed biofilm coverage with microflora of various shapes and sizes including cocci and thick filaments (Figure 4-3). These observations are in agreement with DNA sequencing work reported by Dimas (2016) who identified two main phylogenetic classes of bacteria, namely, rod-shaped alpha-proteobacteria (92\%) and betaproteobacteria (8\%) during late summer months at the same pilot. Additionally, amorphous and circular diatoms (ranging from 2-10 $\mu \mathrm{m}$ ), a common type of phytoplankton in fresh water and soils (Knappe et al., 2004), were observed on the surface (Figure 4-3). 


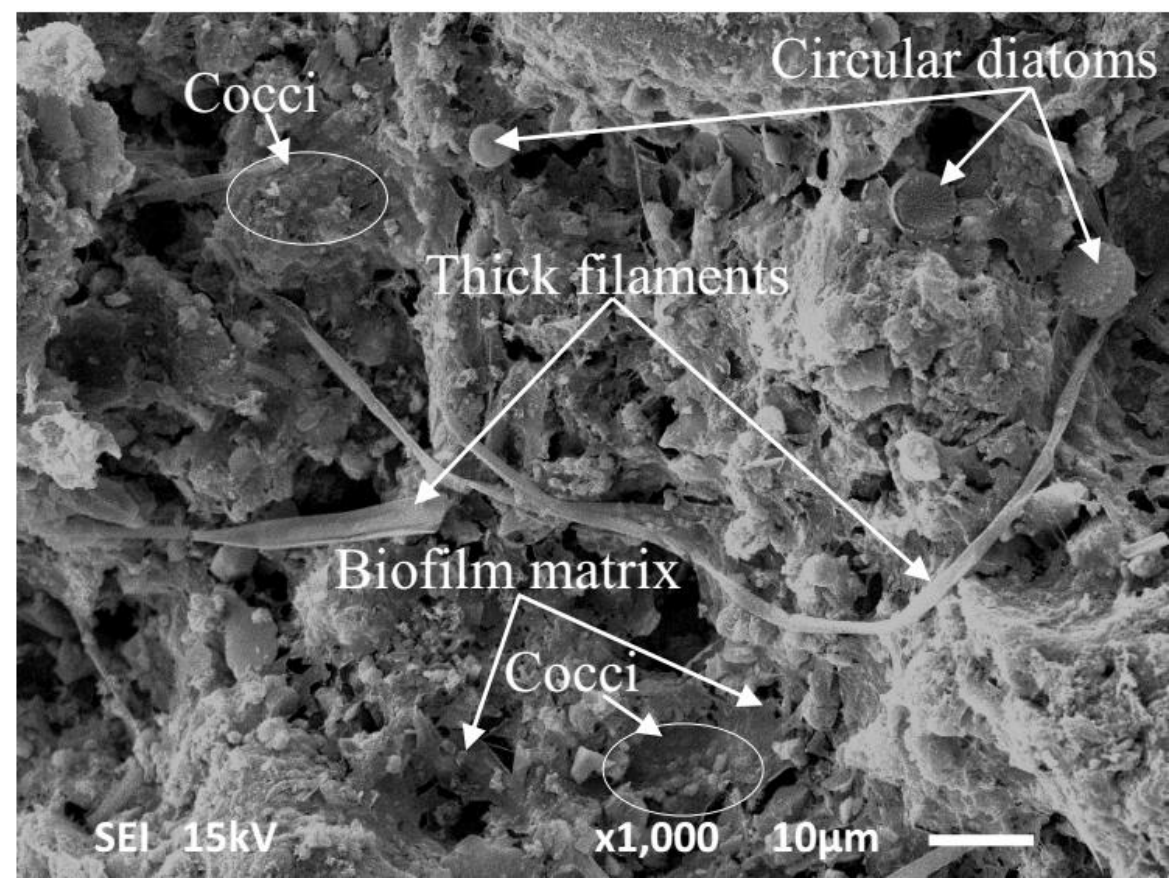

Figure 4-3: SEM micrograph of GAC filter media depicting biofilm attachment at 1000X magnification level.

\subsubsection{Organics Removal}

Raw water DOC ranged between $2.2 \pm 0.2 \mathrm{mg} / \mathrm{L}$ and did not display any seasonal variability. Ozonation had little impact on DOC removal $(0.8 \pm 3.2 \%)$, however a $19.8 \pm 2.5 \%$ reduction in aromatic content was observed, as indicated by $\mathrm{UV}_{254}$ values. Black and Bérubé (2014) reported a similar impact of ozonation on DOC removal $\left(3 \pm 0.5 \%, \mathrm{C}_{0} \sim 5 \mathrm{mg} / \mathrm{L}\right)$ and $\mathrm{UV}_{254}$ reduction $\left(15 \pm 1 \%, \mathrm{C}_{0} \sim 0.165 \mathrm{~cm}^{-1}\right)$ when considering synthetic raw water. Overall, raw water SUVA values $\left(\mathrm{DOC} / \mathrm{UV}_{254}\right)$ remained $<1$, indicating that the source water is predominantly composed of non-humics and low-molecular weight compounds (Edzwald and Tobiason, 1999).

Warmer temperatures $\left(\mathrm{T}>10^{\circ} \mathrm{C}\right)$ were observed to have a positive impact on biofiltration performance. A $0.1-0.3 \mathrm{mg} / \mathrm{L}$ DOC reduction occurred during summer months $\left(16.5 \pm 3.3^{\circ} \mathrm{C}\right)$ when compared to the winter period $\left(6.2 \pm 1.6^{\circ} \mathrm{C}\right)$, irrespective of media type (Figure 4-4). Previous studies have also reported incremental DOC removal as a function of warmer water conditions (Pharand et al., 2014). The increase in organic removal can been attributed to enhanced microbial biodegradation and mass transfer rates (Hozalski et al., 1999; Pharand, 2014). 

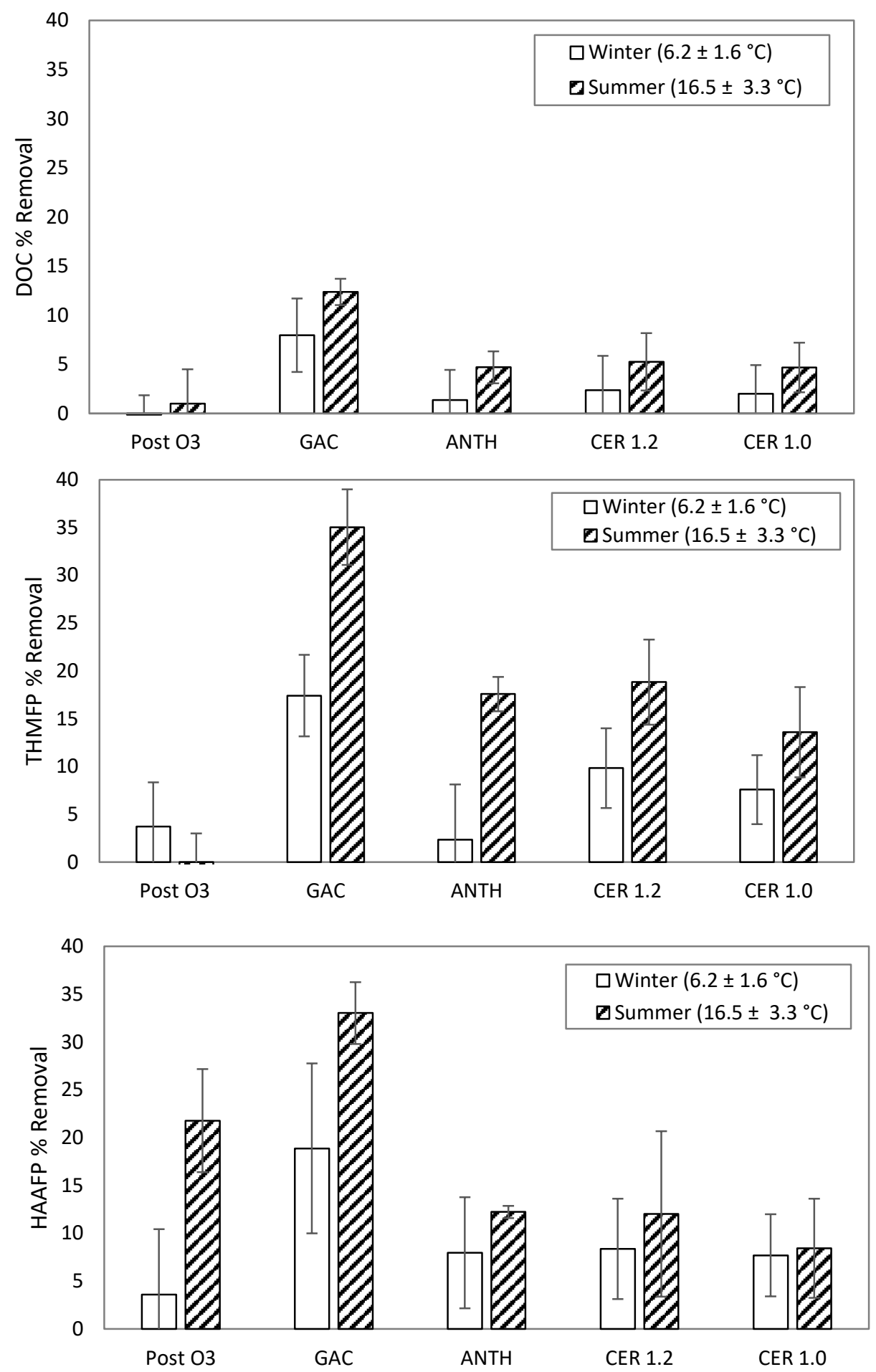

Figure 4-4: DOC and DBPFP removals for post-ozonation, GAC, anthracite, Ceralite $1.2 \mathrm{~mm}$, and Ceralite $1.0 \mathrm{~mm}$ in winter $\left(6.2 \pm 1.6^{\circ} \mathrm{C}\right)$ and summer months $\left(16.5 \pm 3.3^{\circ} \mathrm{C}\right)$. Vertical bars represent one standard deviation (n, number of sampling points for each parameter as reported in Table 4-1. 
Table 4-1: Statistical Comparison of Different Treatments Using Paired T-Tests

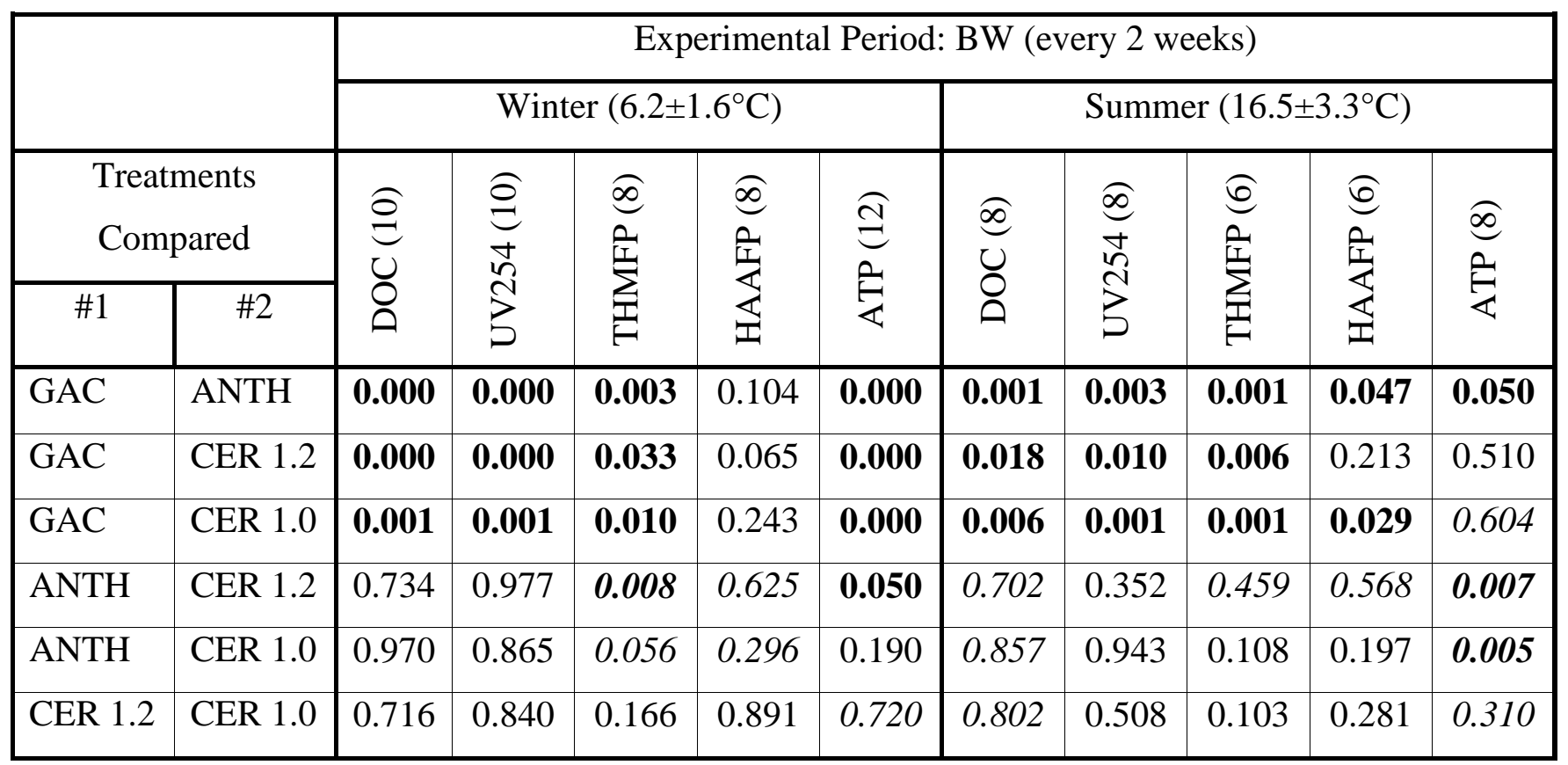

Bold indicates a meaningful difference at $5 \%$ significance level $(\mathrm{p} \leq 0.05)$. Italics represent treatment \#2 is better than treatment \#1. Numbers in parentheses ( ) show the number of samples.

GAC outperformed the other filters during both winter $\left(6.2 \pm 1.6^{\circ} \mathrm{C}\right)$ and summer months $\left(16.5 \pm 3.3^{\circ} \mathrm{C}\right)$, with DOC reduction of $8 \%(0.2 \mathrm{mg} / \mathrm{L})$ and $12.4 \%(0.3 \mathrm{mg} / \mathrm{L})$, respectively. Ceramic media performed slightly better than anthracite with removals ranging between 1-3\% and 4-5\% during winter and summer months, respectively. These findings corroborated values reported by Saltnes et al. (2002), where no significant difference in total organic carbon (TOC) removal was observed when comparing ceramic and anthracite filters receiving in-line coagulated tap water. However other studies using expanded clay material (as biofiltration media) have reported TOC reductions of $13-28 \%\left(\mathrm{C}_{0}=2-5 \mathrm{mg} / \mathrm{L}\right)$ across biofilters when supplied with synthetic raw water containing a humic concentrate which had been pre-treated with ozonation (Melin and Ødegaard, 1999).

\section{Disinfection By-Product Formation Potential (DBPFP) Reduction}

A preferential increase in THM and HAA precursor removals relative to DOC was observed across all biofilters (Figure 4-4). In previous studies, humics and biopolymers were found to be strongly correlated with THM $\left(\mathrm{R}^{2}>0.7\right)$ and HAA $\left(\mathrm{R}^{2}>0.9\right)$ formation suggesting 
that biofiltration selectively degrades these precursors (Wassink et al., 2011). DBPFP removals are presented in Figure 4-4, while the statistical comparisons between different media are shown in Table 4-1. Temperatures $>10{ }^{\circ} \mathrm{C}$ significantly $(\mathrm{p}=0.05)$ improved THMFP and HAAFP removal by a factor of 1.5-2 for all the media types when compared to $<10^{\circ} \mathrm{C}$ (Figure 4-4).

GAC was associated with higher DOC and DBP precursor reduction both during winter and summer months (Table 4-1). Anthracite was equivalent to ceramic media when comparing DOC (4-5\%), THMFP (5-6\%), and HAAFP (8-12\%) reductions during summer months (Figure 4-4).

With similar ATP levels, it was anticipated that ceramic and GAC media would have comparable organic removals. Better DOC and DBPFP removal by GAC may potentially be attributed to differences in the attached microbial community or bio-regeneration of activation sites by microorganisms (Aktaş and Çeçen, 2007). Alternatively, renewal of adsorption sites in GAC as a result of backwashing could also explain the improved reductions across GAC (Emelko et al., 2006). These results confirm that ATP values cannot be directly correlated to biofilter organic degradation potential.

\subsubsection{Enzyme Assay}

Microbial communities attached to filter media are capable of directly metabolizing simple NOM (e.g., sugar, amino- and organic-acids), while complex polymeric compounds (e.g., cellulose, and lignin) are first hydrolyzed into easily biodegradable NOM by enzymes (Lautenschlager et al., 2014). Enzyme activity assays can be used to compare the biofilm activity of different biofilters and to suggest whether different communities have colonized the media. In the present study, esterase and laccase activity were measured to gain insight into the metabolic activities of the attached biofilm for each media type. Esterase is indicative of heterotrophic activity within a given sample (Nybroe et al., 1992), suggesting that the community has the ability to fix organic carbon for growth but cannot utilize carbon from inorganic sources (Hogg, 2013). Esterase activity was highest for GAC $(3.3 \pm 0.1 \mu \mathrm{mol} / \mathrm{min}-\mathrm{g})$ when compared to other media types (Figure 4-5). Anthracite (1.2 $\pm 0.1 \mu \mathrm{mol} / \mathrm{min}-\mathrm{g})$ and CER $1.2(1.6 \pm 0.2 \mu \mathrm{mol} / \mathrm{min}-\mathrm{g})$ had comparable enzymatic reaction rates while CER $1.0(0.8 \pm 0.07 \mu \mathrm{mol} / \mathrm{min}-\mathrm{g})$ had the lowest. Laccase enzyme is produced by plants, fungi, and bacteria and has received the attention of 
researchers in the last decade due to its ability to degrade polymers, and participate in ring cleavage of aromatic compounds (e.g., phenols), nonphenolic lignin-related compounds, as well as highly recalcitrant environmental pollutants (Shraddha et al., 2011). The GAC filter had a higher laccase enzymatic reaction rate $(11.1 \pm 0.3 \mathrm{E}-03 \mu \mathrm{mol} / \mathrm{min}-\mathrm{g})$ compared to the other three.

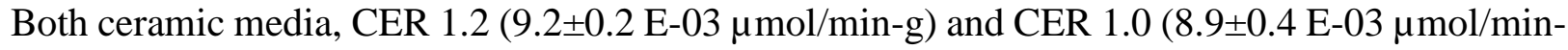
g) had elevated biodegradation capabilities when compared to anthracite $(6.7 \pm 0.2 \mathrm{E}-03 \mu \mathrm{mol} / \mathrm{min}$ g).

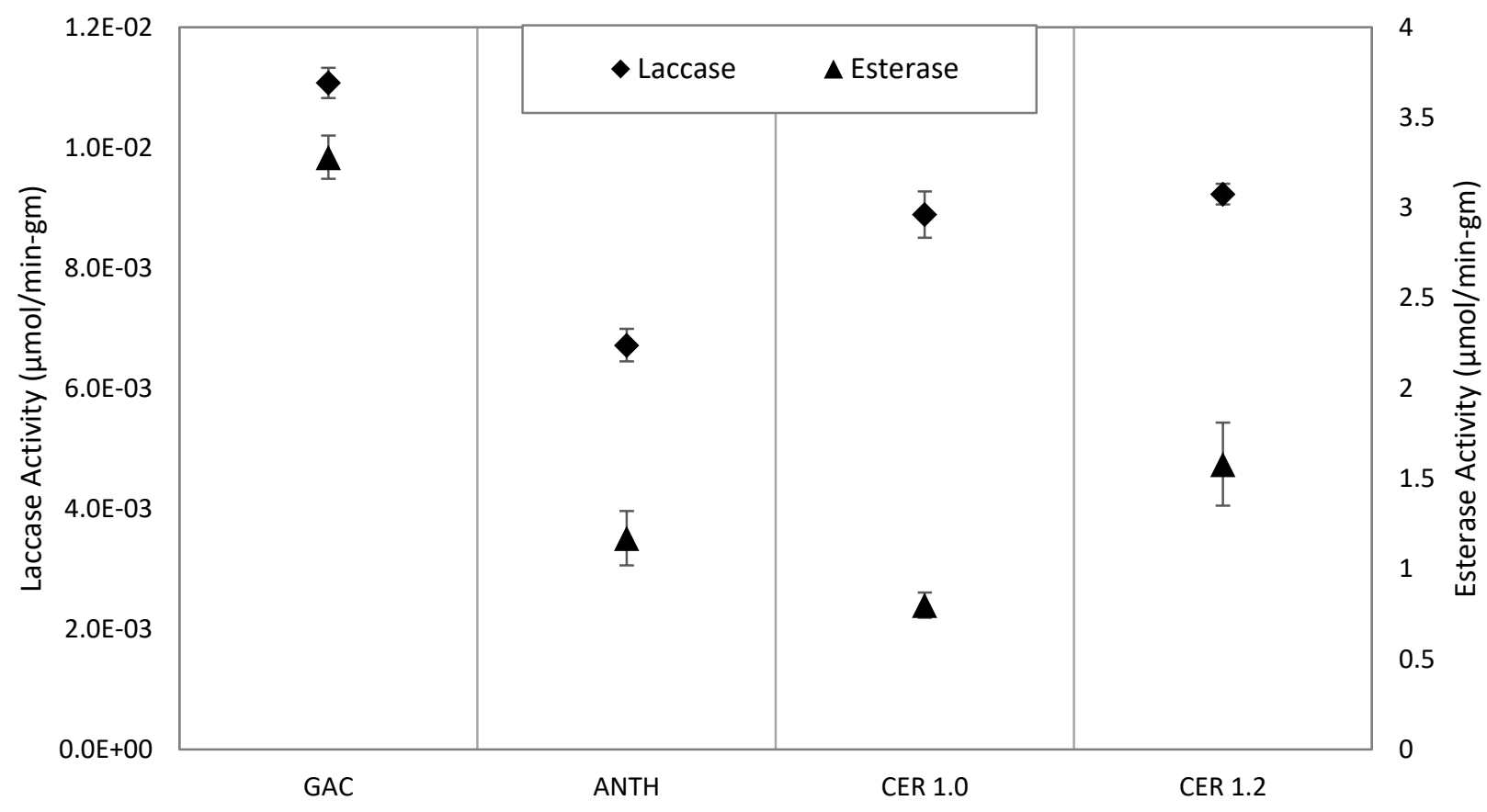

Figure 4-5: Reaction rates of laccase and esterase ( $\mu \mathrm{mol} / \mathrm{min}-\mathrm{gm})$ for each biofiltration media type (GAC, anthracite, Ceralite $1.2 \mathrm{~mm}$, Ceralite $1.0 \mathrm{~mm}$ ). Vertical bars represent one standard deviation ( $\mathrm{n}=4$ for laccase; $\mathrm{n}=3$ for esterase assay).

ATP values correlated strongly with esterase activity $\left(\mathrm{R}^{2}=0.94\right)$ and moderately with laccase $\left(R^{2}=0.76\right)$. A strong relationship $\left(R^{2}=0.95\right)$ was observed between average esterase activities and DOC, THMFP, and HAAFP reductions (Figure 4-6). Additionally, the steeper slope observed for THMFP and HAAFP confirms that biofiltration preferentially removes DBP precursors. Relationships such as these can assist water utilities in selecting a suitable media type for specific treatment requirements, especially where DBP formation is of concern. 


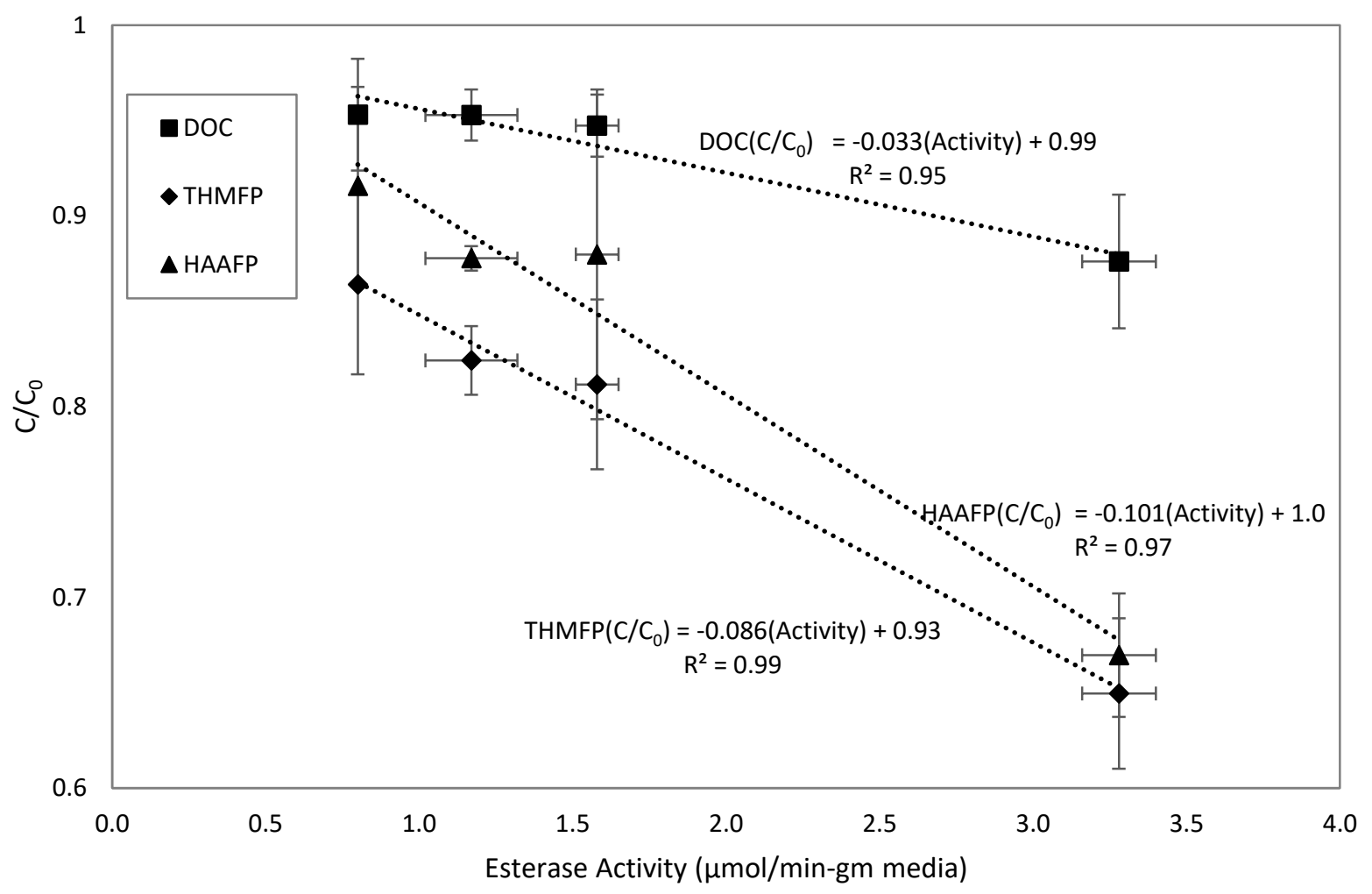

Figure 4-6: DOC, THMFP, and HAAFP normalized to influent values as a function of esterase activity ( $\mu \mathrm{mol} / \mathrm{min}-\mathrm{g})$. Vertical bars (n, number of samples as shown in Table 4-1) and horizontal bars $(n=3)$ represent one standard deviation.

\subsubsection{Operational Performance}

\section{Turbidity}

Biofilter influent turbidity levels varied between $0.54 \pm 0.47$ NTU during the study period, with three notable spikes (2.0, 2.1 and 1.1 NTU). All four filters consistently reduced the effluent turbidities to below 0.25 NTU (Appendix Table 8-7). Ceramic media has higher effective sizes $\left(\mathrm{d}_{10}=1.0\right.$ and $\left.1.2 \mathrm{~mm}\right)$ when compared to anthracite $\left(\mathrm{d}_{10}=0.85 \mathrm{~mm}\right)$ and $\mathrm{GAC}\left(\mathrm{d}_{10}=0.85-1.0 \mathrm{~mm}\right)$, therefore it was anticipated that both anthracite and GAC would perform better than the two ceramic media types (Table 3-2). However, no statistical difference between the four filters was observed in terms of turbidity reduction $(\mathrm{p}<0.05)$, for both cold and warm water conditions (Figure 4-7). This may be a function of the inherent low source water turbidity (<1 NTU). 


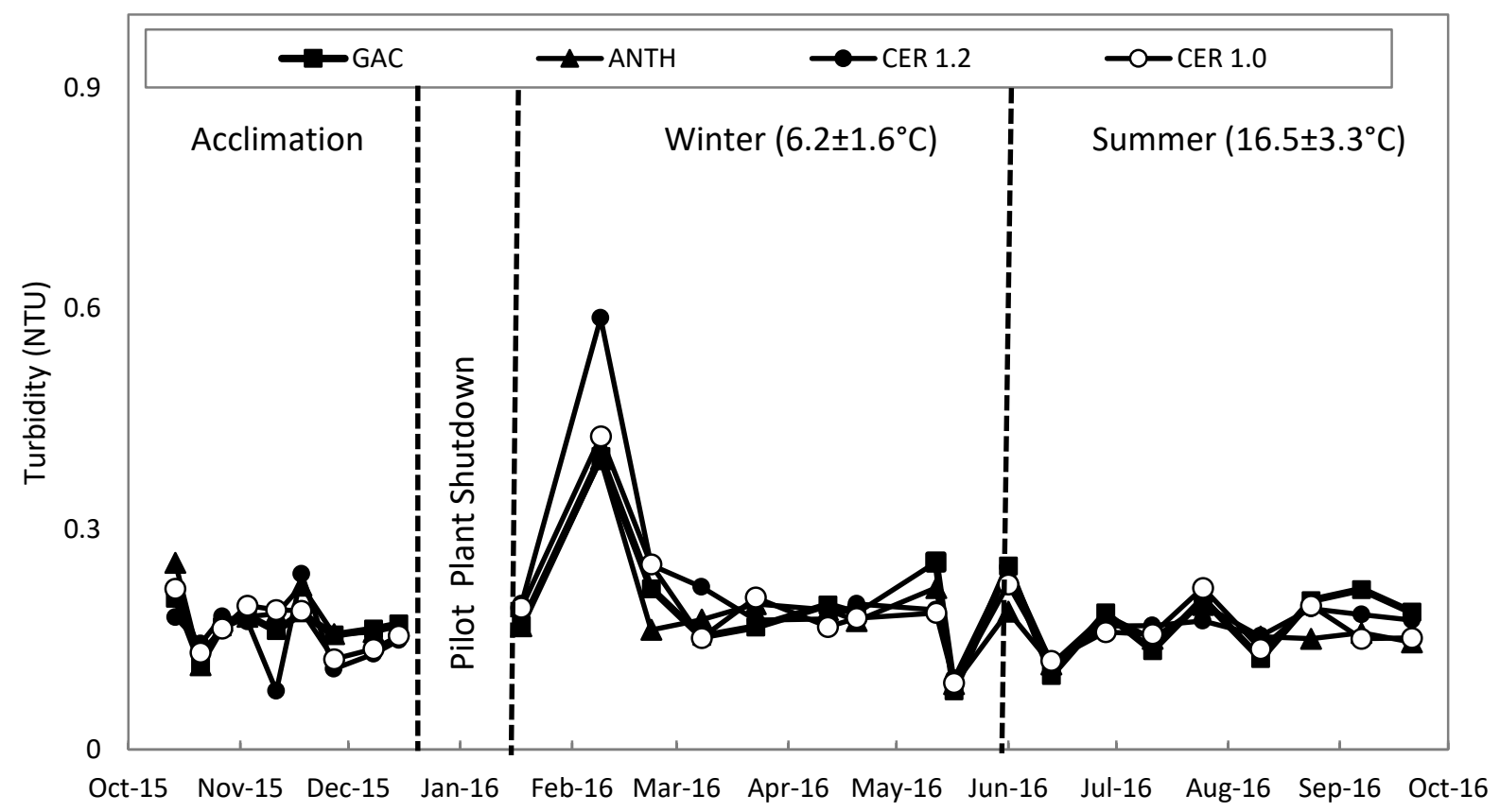

Figure 4-7: Biofilter effluent turbidity values for four different media types (GAC, anthracite, Ceralite $1.2 \mathrm{~mm}$, and Ceralite $1.0 \mathrm{~mm}$ ).

\section{Headloss}

The headloss profile for each filter between backwash (BW) periods is presented in Figure 4-8. On average, for CER 1.2 and CER 1.0 slower headloss development was observed $(0.6 \mathrm{~cm} /$ day and $1.2 \mathrm{~cm} /$ day, respectively) when compared to GAC $(1.2 \mathrm{~cm} /$ day $)$, and anthracite $(1.8 \mathrm{~cm} /$ day). The similarity between GAC and CER 1.0 is likely due to their comparable effective sizes. When comparing filter run times to reach terminal headloss, it is estimated that CER 1.2 can operate 2.3 times longer than anthracite, while CER 1.0 and GAC can achieve 1.5 times longer filter run times. This could translate into potential savings in terms of lower energy and water requirements with respect to filter operation (Davies and Wheatley, 2012). For this study, filter runs were terminated by turbidity breakthrough ( $>0.1 \mathrm{NTU}$ ) rather than the terminal headloss $(1 \mathrm{~m})$.

From an operational perspective, the intrinsically higher effective size of the ceramic media could serve as an alternative to GAC and anthracite in terms of providing longer filter run times, without impacting effluent turbidity. Future studies are needed to evaluate the performance of ceramic media in highly turbid waters. 


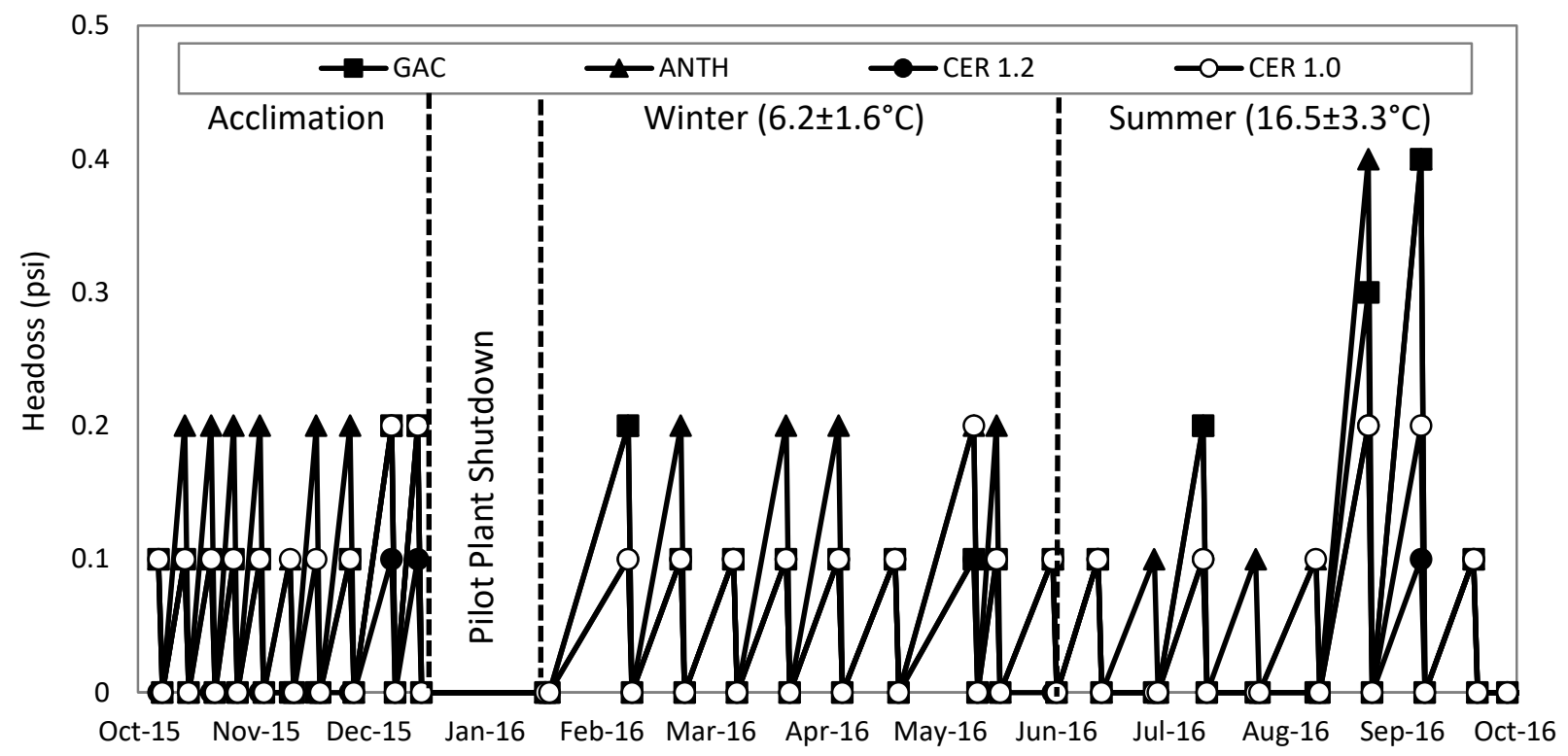

Figure 4-8: Headloss development for four different media types (GAC, anthracite, Ceralite 1.2 $\mathrm{mm}$, and Ceralite $1.0 \mathrm{~mm}$ ).

\subsection{Conclusions}

- Ceramic media required longer acclimation times (6-7 months) when compared to GAC (45 days) and anthracite (2 months). Once acclimated, ATP levels matched that of GAC; however, increased biomass did not translate into increased DOC and DBPFP removal for ceramic media.

- GAC media outperformed ceramic media in terms of DOC and DBPFP reduction. However, ceramic media achieved higher reductions in organic carbon, especially during cold water conditions $\left(\mathrm{T}<10^{\circ} \mathrm{C}\right)$.

- Enzyme activities correlated well with DOC and DBPFP (normalized to influent) and provided insight regarding the metabolism of attached biofilm. SEM microscopy with EDX allowed for qualitative and elemental characterization of attached microbial biofilm.

- When considering head loss development, use of ceramic media could extend filter runs by 1.5-2.3 times when compared to anthracite.

- Further studies are required in high organic and turbid source water to assess the overall performance of ceramic media. 


\section{Manganese (Mn) and Iron (Fe) Removal Using Pilot-Scale Biofiltration}

\subsection{Introduction}

The presence of dissolved manganese $(\mathrm{Mn})$ and iron $(\mathrm{Fe})$ in source waters poses aesthetic, organoleptic, and operational challenges for drinking water utilities (Khadse et al., 2013). Even at low concentrations, $\mathrm{Mn}(\sim 0.15 \mathrm{mg} / \mathrm{L})$ and $\mathrm{Fe}(\sim 0.3 \mathrm{mg} / \mathrm{L})$ contribute to turbidity, taste \& odor , and colour which may stain water pipes, laundry, and plumbing fixtures (Mouchet, 1992). In addition, neurotoxic effects in children have been reported at Mn concentrations > $200 \mu \mathrm{g} / \mathrm{L}$ (Bouchard et al., 2011). Health Canada mandated an aesthetic objective of $0.05 \mathrm{mg} / \mathrm{L}$ and 0.3 $\mathrm{mg} / \mathrm{L}$ for Mn and Fe, respectively (Health Canada, 2012).

Traditional physico-chemical approaches for inorganic removal include a primary step, such as chemical oxidation $\left(\mathrm{O}_{3}, \mathrm{ClO}_{2}\right.$, and $\left.\mathrm{KMnO}_{4}\right)$, aeration, or use of $\mathrm{Mn}$ greensand followed by filtration /biofiltration (Somerfield 1999). Continuous application of chemical oxidant is the most common approach, where oxidation reduction potential (ORP) is increased such that dissolved $\mathrm{Mn}(\mathrm{II}) / \mathrm{Fe}(\mathrm{II})$ are oxidized and precipitate as insoluble oxides of $\mathrm{Mn}(\mathrm{IV}) / \mathrm{Fe}(\mathrm{III})$ (Kohl and Medlar, 2006). However, continuous maintenance of a desired ORP regime is difficult in practice.

Biofiltration has been shown to effectively remove inorganics with lower operation and maintenance $(\mathrm{O} \& \mathrm{M})$ costs at higher throughput rates when compared to chemical treatment (Burger et al., 2008). During biofiltration, soluble Mn and Fe are metabolized by Mn- and Feoxidising bacteria either through direct microbial enzymatic oxidation or indirect modification (elevated $\mathrm{pH}$ and/or ORP) (Diem and Stumm, 1984). The bacterial community can oxidize soluble $\mathrm{Mn}$ and Fe to insoluble oxides of $\mathrm{Mn}$ (IV) and Fe(III) which then precipitate on the surface and become integrated within the biofilm (Sahabi et al., 2009). Integration of biologically oxidised inorganics provides stability and prevents further desorption of Mn and Fe (Sahabi et al., 2009).

Much of the published literature concerning inorganic removal using biofiltration is related to ground water (Burger et al., 2008; Katsoyiannis and Zouboulis, 2004; Qin et al., 2009), while only few studies have investigated surface water. Lauderdale et al. (2012) reported $>98 \%$ Mn removal when nutrients (phosphoric acid $\sim 0.02 \mathrm{mg} / \mathrm{L}$ ) and oxidants (hydrogen peroxide $\sim 1 \mathrm{mg} / \mathrm{L}$ ) were added prior to pilot-scale granular activated carbon (GAC) biofilters. The authors 
however, did not state whether the removal mechanism was microbial metabolism or peroxide oxidation. Kohl and Dixon (2012) examined several surface waters and reported that full-scale biofiltration could achieve $>97 \% \mathrm{Mn}$ removal for a $\mathrm{pH}$ range of 7.2-7.6. Granger et al., (2014) demonstrated a $91 \%$ Mn removal $\left(\mathrm{C}_{0}=327 \pm 277 \mu \mathrm{g} / \mathrm{L}\right)$ in phosphorus enhanced bench-scale biofilters for surface water at $\mathrm{pH} 6$, while only $70 \% \mathrm{Mn}$ removal was observed under alkaline conditions ( $\mathrm{pH} 9-11)$.

In the present study, pilot-scale biofilters were compared to conventional anthracite filters in terms of both inorganic (Mn, Fe) and organic removals (DOC, $\mathrm{UV}_{254}, \mathrm{DBP}$ formation potential). To assess the impact of historical turbidity events, filter operation was also assessed in terms of headloss and turbidity reduction.

\subsection{Materials and Methods}

\subsubsection{Pilot Plant Configuration}

Pilot-scale studies were carried out at the Elgin Area Water Treatment Plant (WTP) located on Lake Erie in London, Ontario, Canada. Raw water is pre-chlorinated to achieve a free chlorine residual of $\sim 0.2 \mathrm{mg} / \mathrm{L}$ for zebra mussel control at temperatures $>12^{\circ} \mathrm{C}$. The Elgin Area WTP is a conventional water treatment facility consisting of coagulation, flocculation, sedimentation, pre-filter chlorination, filtration, and post-filter chlorination processes.

The pilot consisted of four filter trains, which were supplied with Elgin Area WTP fullscale filter influent (settled and chlorinated water $\sim 0.35 \mathrm{mg} / \mathrm{L}$ residual); source water and influent water quality parameters are presented in Table 3-1. Each of the four filters (internal diameter $=$ $7.62 \mathrm{~cm}$; EBCT $=16 \mathrm{~min})$ contained $50 \mathrm{~cm}$ of anthracite $\left(\mathrm{d}_{10}=0.85, \mathrm{UC}=1.4\right)$ over $50 \mathrm{~cm}$ of sand $\left(\mathrm{d}_{10}=0.5, \mathrm{UC}=1.8\right)$ and were operated in a constant head mode with declining flow rate (Figure 3-2). The filters were backwashed with their own effluent twice a week. Backwash consisted of $30 \%$ fluidization for 2 minutes, followed by a $50 \%$ fluidization for 4 minutes, and finally $30 \%$ fluidization for 4 minutes.

During pilot start-up, all the filters received settled/chlorinated water for a period of three months (January-March). All filters had similar $(\mathrm{p}=0.05)$ performance profiles in terms of turbidity, DOC, and DBP precursor removal. In the Spring and the Summer months (MarchAugust), conventional anthracite filters (CAF1 and CAF2) received settled/chlorinated water 
while biological anthracite filters (BAF1 and BAF2) received settled water quenched with calcium thiosulphate (CTS) to allow operation in a biological mode. To help encourage biological growth, CAF1 and BAF2 were fed with raw water during Fall months (August-November), while no changes were made to the operating conditions of CAF2 and BAF1, as they served as controls.

\subsubsection{Analytical Methods}

Dissolved organic carbon (DOC) was measured using a persulfate wet oxidation method as described in Standard Method 5310 D (APHA,2012) with an O-I Corporation Model 1010 TOC Analyzer (College Station, Texas, USA). A CE 3055 Single Beam Cecil UV/Visible Spectrophotometer (Cambridge, England) with $1 \mathrm{~cm}$ quartz crystal cuvette (Hewlett Packard, Mississauga) was used for measuring ultraviolet absorbance at $254 \mathrm{~nm}$ (UV254).

Biological filter media samples were collected from the top 5-10 cm layer of the biofilters. Biomass on the filter media surface was measured as adenosine triphosphate normalized to the weight of the filter media (ng ATP/g media) using a LuminUltra Deposit Surface Analysis Kit (DSA-100C, Fredricton, NB) as per the manufacturer's instructions.

Samples for dissolved manganese and iron analysis were prepared by filtering $10 \mathrm{~mL}$ samples through $0.45-\mu \mathrm{m}$ syringe filters and preserved by adding $0.25 \%$ (v/v) nitric acid to $\mathrm{pH}<$ 2 according to Standard Method 3030 B (APHA, 2012). All samples were stored at $4^{\circ} \mathrm{C}$ until time of analysis. Dissolved manganese and iron concentrations in the samples were determined using inductively coupled plasma optical emission spectrometry (ICP-OES) with an Optima 7300 DV ICP-OES 20 spectrometer (PerkinElmer, Waltham, MA) based on the U.S. EPA Method 6010B (APHA, 2012). Method detection limit for manganese and iron was $10 \mu \mathrm{g} / \mathrm{L}$.

For DBP analyses, water samples were chlorinated in duplicate to achieve a free chlorine target residual of $1.5 \pm 0.5 \mathrm{mg} / \mathrm{L}$ after $24 \pm 2$ hours at $20^{\circ} \mathrm{C}$, where $\mathrm{pH}$ matched that observed at full-scale (APHA, 2012). Free chlorine residuals were measured as per Standard Methods 4500Cl G (APHA, 2012), and quenched with L-ascorbic acid. Liquid-liquid extraction and gas chromatography were used to analyze four THMs (chloroform, bromodichloromethane, dibromochloromethane, and bromoform) and nine HAAs (monochloroacetic acid, monobromoacetic acid, dichloroacetic acid, trichloroacetic acid, bromochloroacetic acid, dibromoacetic acid, bromodichloroacetic acid, dibromochloroacetic acid, and tribromoacetic 
acid) as per Standard Method 6232 B and 6251, respectively (APHA, 2012). A Hewlett Packard 5890 Series II Plus Gas Chromatograph (Mississauga, Ontario, Canada) equipped with an electron capture detector (GCECD) and a DB 5.625 capillary column (Agilent Technologies Canada Inc., Mississauga, Ontario, Canada) was used for both THM and HAA analysis.

\subsection{Statistical Analysis}

A two-tailed paired test (95\% significance level) was used to compare the performance of the four filters, while a single-tailed test (95\% significance level) was used to assess the performance of a particular treatment as compared to the influent water as described by McKie et al. (2015). Reported p-values indicate the level at which the difference between two treatments was statistically significant.

\subsection{Results and Discussion}

\subsubsection{Biological Characterization of the Filter Media}

Active biomass attached to the media surface was quantified using adenosine triphosphate (ATP) measurements and expressed as ng of ATP/g of media. Following 150 days of operation in Spring and the Summer months, low biological activity ( $<15 \mathrm{ng} / \mathrm{g}$ ) was observed on all the filters (Figure 5-1). This lack of biological acclimation with the settled, chlorinated influent could be a function of low nutrient content due to the coagulation process or lack of viable biomass upon exposure to chlorine. Due to the variability in $\mathrm{Cl}_{2}$-residuals, biologically operated filter (BAF1 and BAF2) influents were not fully quenched on a few occasions and received 0.2-0.9 $\mathrm{mg} / \mathrm{L}$ free chlorine for periods of less than four days.

In August, raw water was fed to the BAF2 (receiving quenched settled water) and CAF2 (receiving settled chlorinated water) for the Fall months to encourage microbial colonization on the media. Following 45 days of filter operation, BAF2 developed an active biomass concentration of $117 \pm 37 \mathrm{ng}$ ATP/g media (Figure 5-1). These values are typical for pilot-scale anthracite filters in Southern Ontario $(135 \mathrm{ng} / \mathrm{g}$; DOC $2.0 \mathrm{mg} / \mathrm{L})$ receiving raw water pre-treated with ozone (McKie et al., 2015). However, CAF1 (25 \pm 9 ng ATP/ g media) did not biologically acclimate with raw water; it is hypothesized that the exposure to chlorine may have modified the surface characteristics for optimal microbial attachment. 


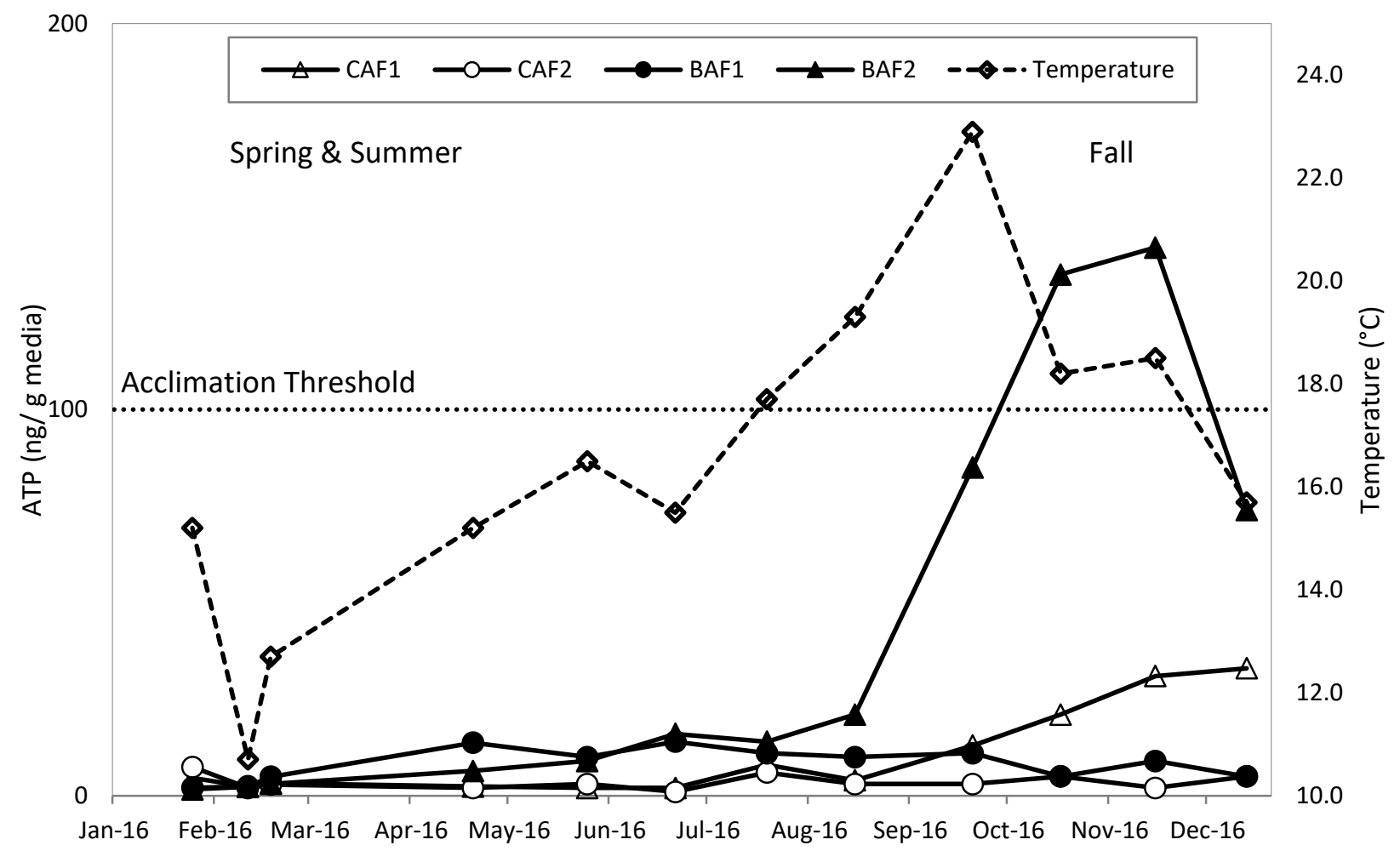

Figure 5-1: ATP concentrations (ng ATP/g media) for the pilot-scale filters. Temperature is plotted on the secondary axis. CAF1 and BAF2 received raw water during the Fall months (August-November).

\subsubsection{Manganese (Mn) and Iron (Fe) Removal}

Average dissolved manganese $(\mathrm{Mn})$ and iron $(\mathrm{Fe})$ concentrations for the Fall months (August, 2016- November, 2016; $\mathrm{n}=18$ ) are presented in Figure 5-2. Manganese and iron concentration in raw water showed high variability, ranging between $15.4 \pm 20.3 \mu \mathrm{g} / \mathrm{L}$ and $183.5 \pm 220.3 \mu \mathrm{g} / \mathrm{L}$, respectively.

Biologically operated filters receiving raw water (CAF1 and BAF2) consistently reduced iron to below the aesthetic objective of $300 \mu \mathrm{g} / \mathrm{L}$ during Fe spike events (Figure 5-3). However, these filters experienced manganese breakthrough four times during the study period (Figure 5-4). It appears that the first manganese release (marked as 0) was triggered by shifts in water chemistry (change in feed water and $\mathrm{pH}$ ), whereas the other three breakthrough events $(1,2$, and 3 ) coincided with seasonal turbidity spikes for both iron (Figure 5-3) and manganese (Figure 5-4). 


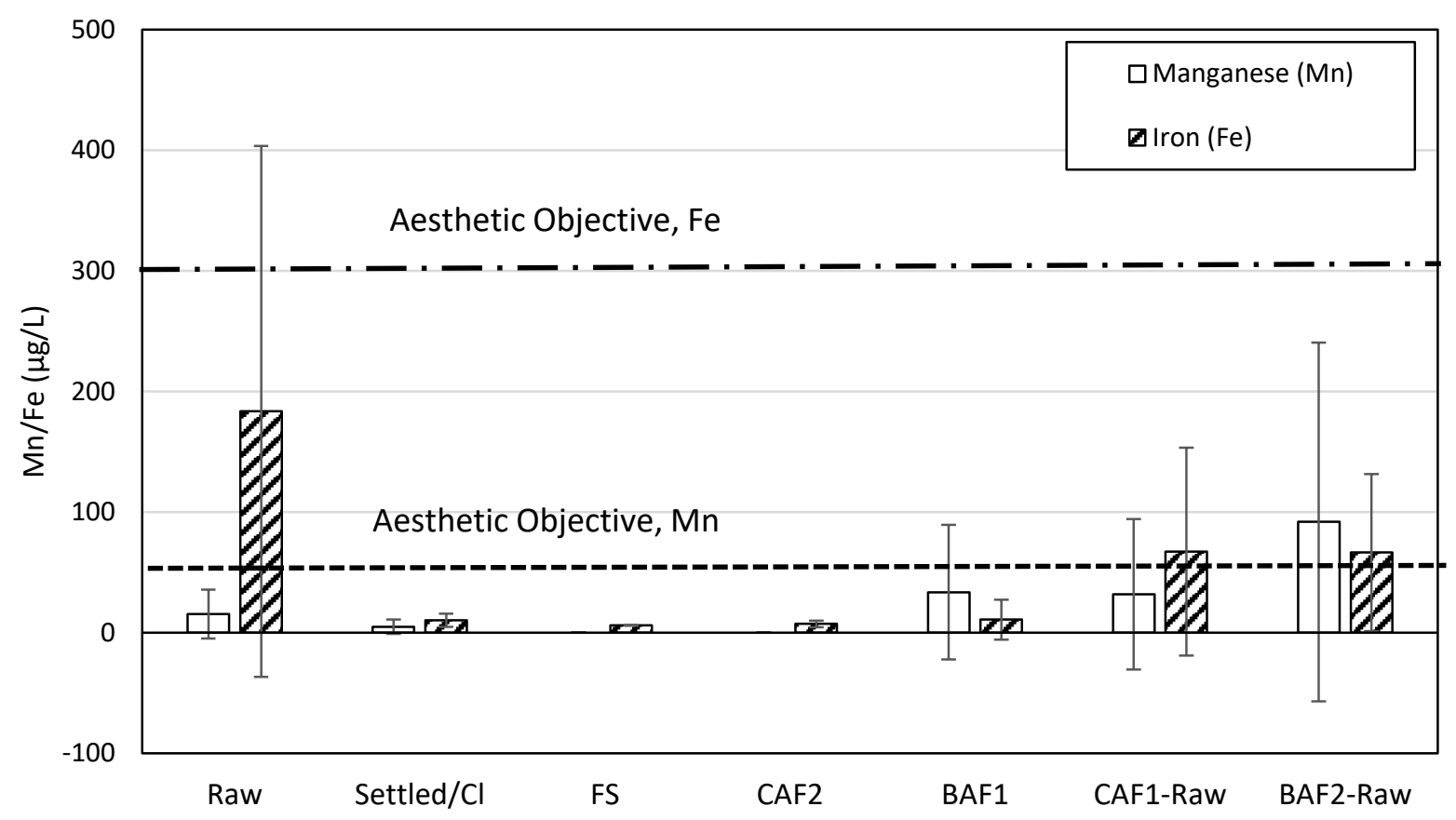

Figure 5-2: Average dissolved manganese and iron $(\mu \mathrm{g} / \mathrm{L})$ concentrations in raw, settled water (Settled/Cl), full-scale (FS) and pilot-scale filter effluents during the Fall months (AugustNovember). Vertical bars represent one standard deviation $(\mathrm{n}=18)$.

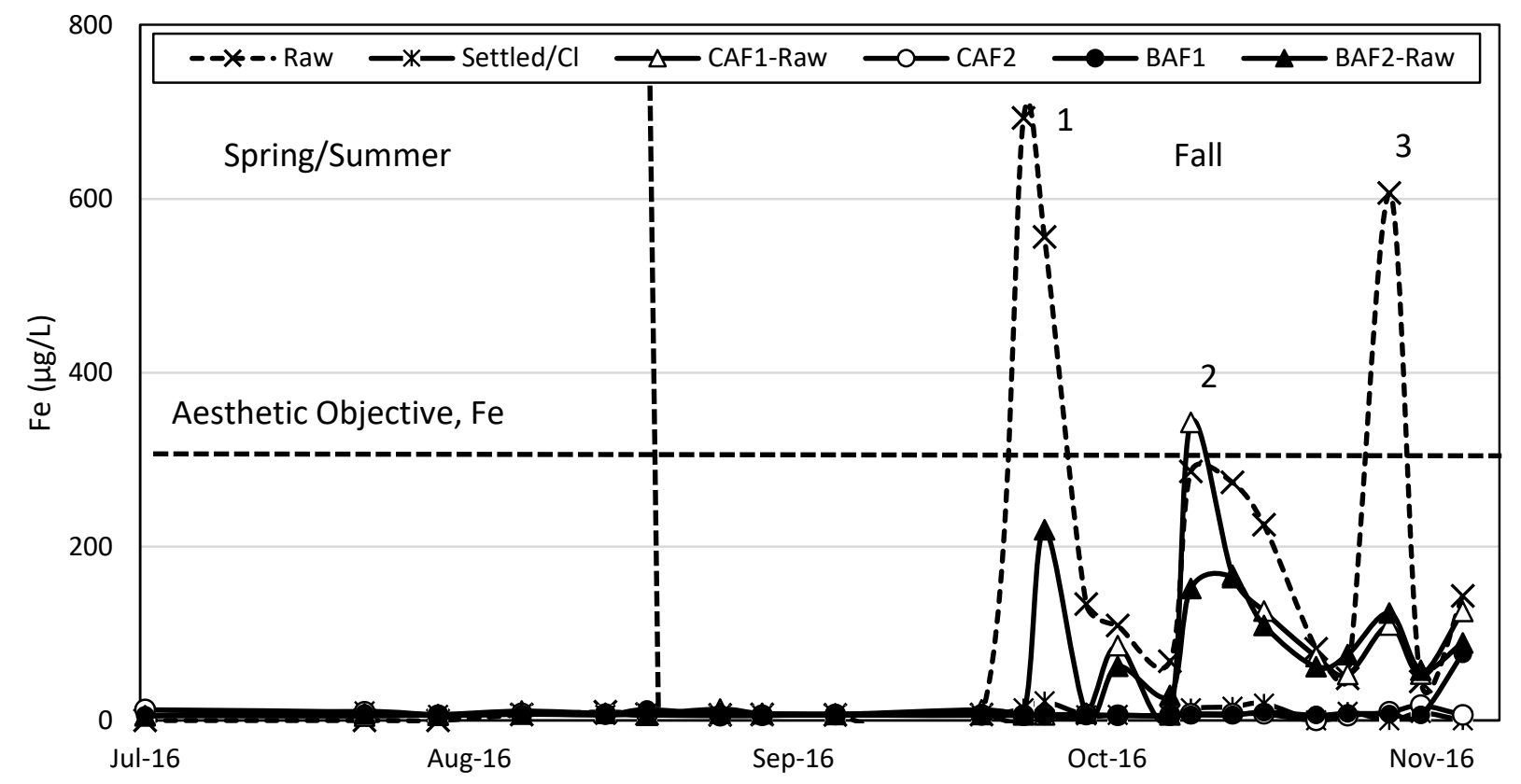

Figure 5-3: Dissolved Fe $(\mu \mathrm{g} / \mathrm{L})$ values in raw, settled water, pilot filter effluents. Note: BAF2 and CAF1 filters were switched to raw water during Fall months (August-November). 


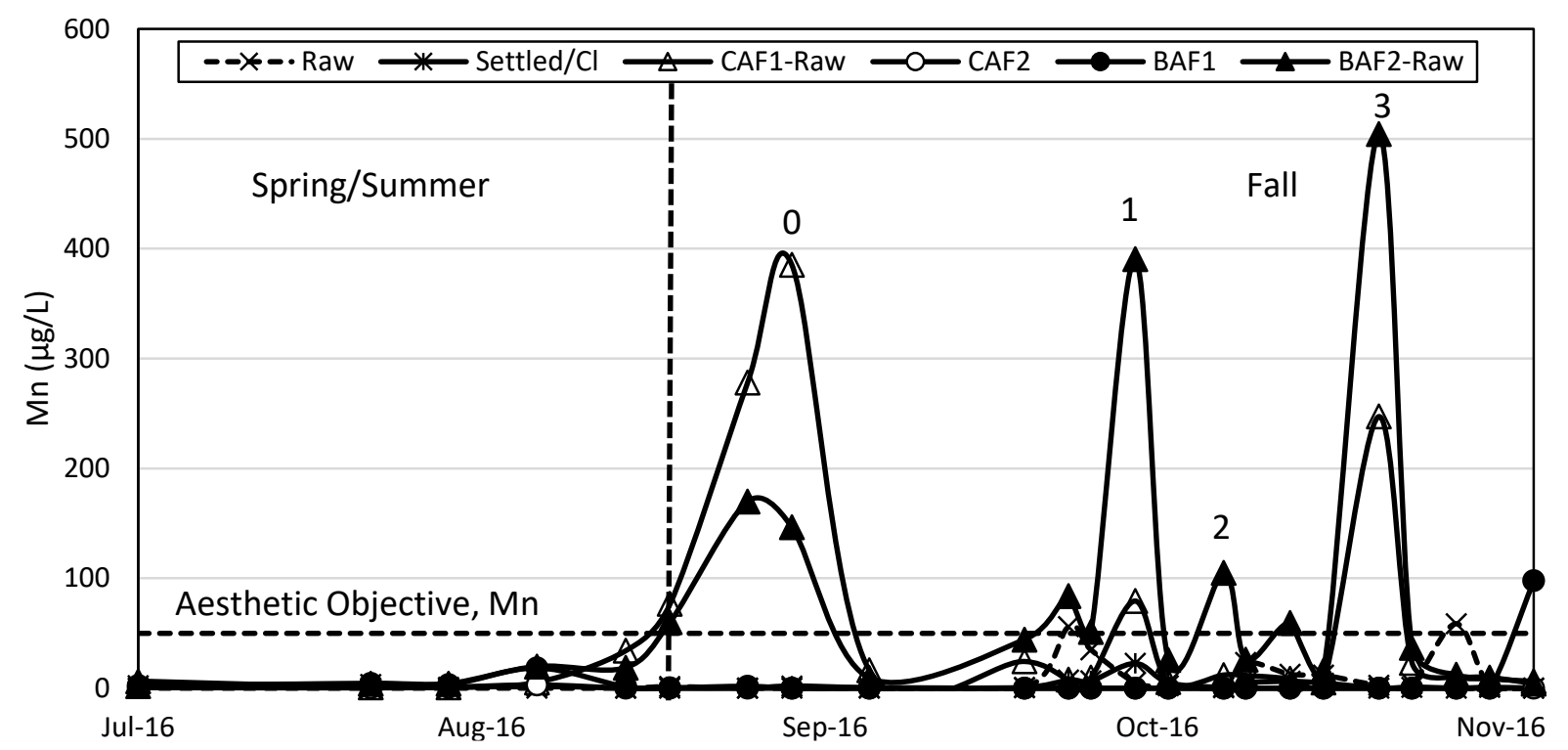

Figure 5-4: Dissolved Mn ( $\mu \mathrm{g} / \mathrm{L})$ values in raw, settled water, pilot filter effluents. Note: BAF2 and CAF1 filters were switched to raw water during Fall months (August-November).

\section{Shifts in Water Chemistry}

Shifts in influent water chemistry $(\triangle \mathrm{pH}= \pm 0.25$ units, below $\mathrm{pH} 8)$ have been shown to increase effluent Mn levels that accumulated in the biofilm (Gabelich et al., 2006). Additionally, changes in feed water, and widely varying chlorine residuals should be avoided to minimize manganese breakthrough occurrence (Brandhuber et al., 2015). During the Fall months, when $\mathrm{CAF} 1$ and BAF2 were switched to raw water, $\mathrm{pH}$ increased to 7.6 from 7.2. This resulted in a manganese release of $280-390 \mu \mathrm{g} / \mathrm{L}$ and 146-170 $\mu \mathrm{g} / \mathrm{L}$ from the conventional (CAF1) and biologically operated filters (BAF2), respectively, denoted as peak 0 in Figure 5-4. These results were counterintuitive since the biologically operated filter (BAF2) with a low amount of attached biomass (17 $\pm 4 \mathrm{ng} \mathrm{ATP} / \mathrm{g})$ should have leached more manganese when compared to conventionally operated filter (CAF1) (Sahabi et al., 2009). However, Gabelich et al. (2005) observed that manganese accumulates on the surface of filter over time when free chlorine is present. In chlorinated environments, sorbed $\mathrm{Mn}(\mathrm{II})$ is rapidly oxidized on the media surface and becomes integrated within the $\mathrm{MnOx}$ (s) biofilm, thereby regenerating the $\mathrm{Mn}$ (II) adsorption sites and increasing further accumulation (Knocke et al., 1991). As such, elevated levels of manganese in the conventionally operated filters can be attributed to the presence of chlorine $(0.22 \pm 0.18$ $\mathrm{mg} / \mathrm{L}$ ), prior to switching the influent to raw water. This observation is in agreement with results 
reported by Gabelich et al. (2005) at the Henry J. Mills Filtration Plant in Riverside, California, where a Mn release of 70-110 $\mu \mathrm{g} / \mathrm{L}$ was observed from full-scale anthracite filters after free chlorine was quenched with sodium thiosulfate and the $\mathrm{pH}$ was increased to 8.3 from 6.3.

\section{Seasonal Turbidity Spikes}

Due to shallow depths of Lake Erie $(\sim 19-64 \mathrm{~m})$, seasonal fluctuations in turbidity are common with raw water values showing high variability (1.0 - 98 NTU, Figure 5-5). A moderate correlation was observed between raw water turbidity and iron $\left(\mathrm{R}^{2}=0.64\right)$, while a weak correlation was elucidated with manganese concentration $\left(\mathrm{R}^{2}=0.25\right)($ Table 5-1). Overall, the turbidity spike events coincided with increase in raw water manganese and iron concentrations (Figure 5-5).

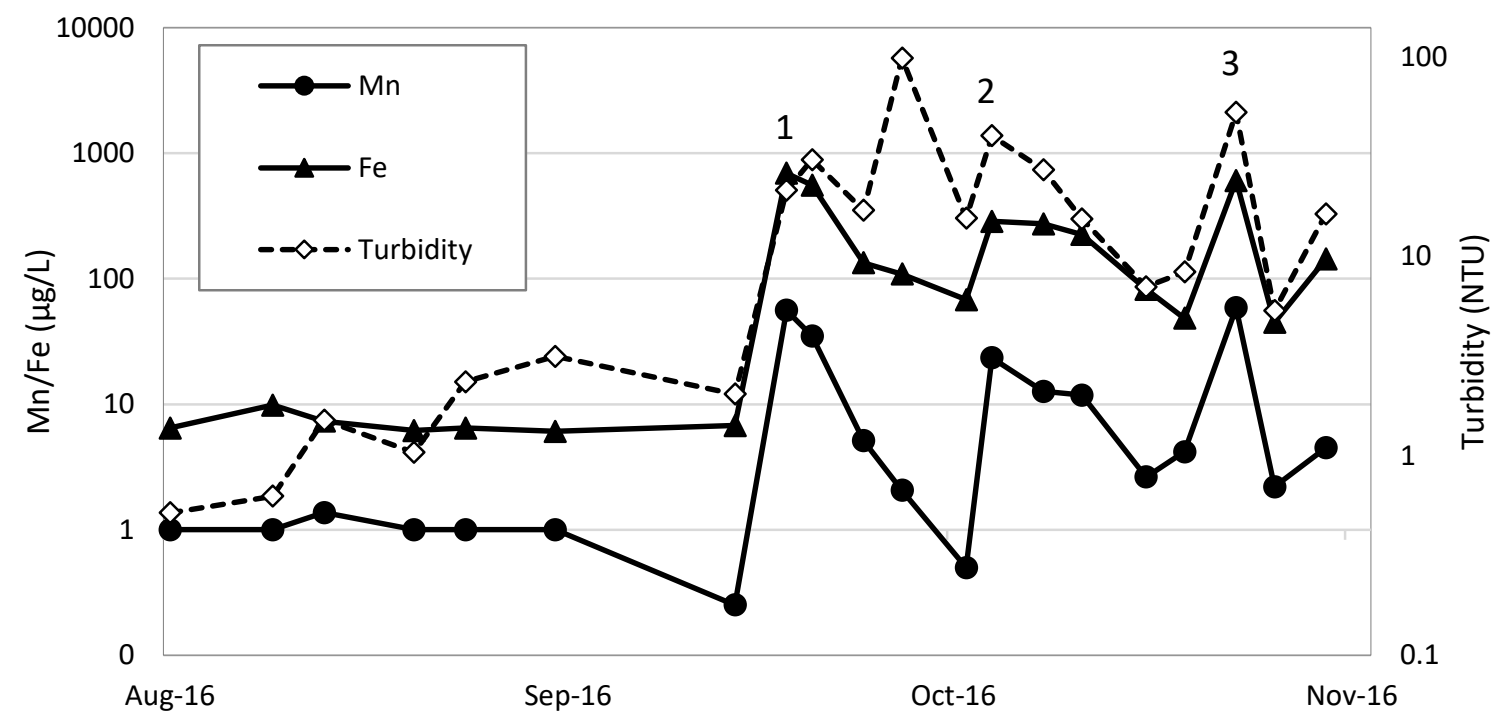

Figure 5-5: Relationship between raw water turbidity (NTU), iron and manganese concentration $(\mu \mathrm{g} / \mathrm{L})$. Turbidity is plotted on the secondary axis. Logarithmic scales are used to highlight differences. Three spike events are denoted as 1,2, and 3 .

Table 5-1: R-Squared Values for Linear Correlations Between Turbidity and Inorganic Constituents (Mn and Fe)

\begin{tabular}{|l|l|}
\hline & Turbidity (NTU) \\
\hline Iron $(\mathrm{Fe})$ & 0.64 \\
\hline Manganese $(\mathrm{Mn})$ & 0.25 \\
\hline
\end{tabular}


Coagulation with alum, followed by settling was effective for removing manganese and iron concentrations to below $10 \mu \mathrm{g} / \mathrm{L}$ and showed high robustness during extreme spike events (Figure 5-2). Biological filters (CAF1, BAF2) receiving raw water had higher effluent manganese concentrations (76.6-504.5 $\mu \mathrm{g} / \mathrm{L})$ than the influent (23.1-74.5 $\mu \mathrm{g} / \mathrm{L})$ during spike events. As expected, BAF2-Raw $(77.6 \pm 153.6 \mu \mathrm{g} / \mathrm{L})$ with higher attached biomass $(117 \pm 37 \mathrm{ng}$ ATP/g) contributed more manganese when compared to CAF1-Raw $(17.4 \pm 69.5 \mu \mathrm{g} / \mathrm{L} ; 25 \pm 9 \mathrm{ng}$ ATP/g) during turbidity spike events (Figure 5-4). It can be hypothesized that anthracite-bound manganese is released when the biofilm experiences stress conditions (Hakes et al., 2016); however, future experiments to verify manganese release mechanism are needed. Barloková and

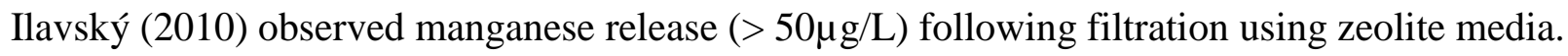

In contrast, biologically operated filters that received raw water, BAF2 and CAF1, achieved a significant $(\mathrm{p}=0.05$ ) reduction in iron; influent values of $183.5 \pm 220 \mu \mathrm{g} / \mathrm{L}$ decreased to $66.4 \pm 65.0 \mu \mathrm{g} / \mathrm{L}$ and $67.1 \pm 86.2 \mu \mathrm{g} / \mathrm{L}$ in effluents, respectively (Figure 5-3). The acclimated filter (BAF2-Raw) had slightly better performance than CAF1-Raw, but no statistically significant difference was observed $(\mathrm{p}=0.05)$. It is possible that manganese release during spike events can be due to displacement of anthracite-bound $\mathrm{Mn}(\mathrm{IV}) / \mathrm{Mn}$ (II) by $\mathrm{Fe}(\mathrm{III})$ as evidenced from iron uptake across biologically operated biofilters (Gabelich et al., 2006).

The removal of manganese $(\mathrm{Mn})$ requires more stringent conditions (higher redox potential) than iron ( $\mathrm{Fe}$ ) (Mouchet, 1992; Qin et al., 2009). Moreover, establishing a manganese precipitating bacteria on biofilm conducive to manganese removal can take up to 6 months if the raw water is deficient of manganese oxidizing bacteria (MnOB) (Seppanen, 1988). A previous full-scale study reduced start-up time by inoculating with microorganisms and achieving $>90 \%$ reduction $\left(\mathrm{C}_{0}=575-3050 \mu \mathrm{g} / \mathrm{L}\right)$ in Mn concentration within 2-3 months of filter operation (Li et al., 2005). Another pilot-scale study conducted by Cai et al. (2015) reported no removal of manganese $\left(\mathrm{C}_{0}=600-1000 \mu \mathrm{g} / \mathrm{L}\right)$ for 51 days of filter operation; however, filters which received inoculum exhibited complete manganese removal $(<10 \mu \mathrm{g} / \mathrm{L})$ after 38 days. Future studies with $\mathrm{MnOB}$ inoculum in anthracite biofilters to accelerate the acclimation process could be examined to fully evaluate the manganese removal potential of biofiltration. 


\subsubsection{Organic Carbon Removal}

Pilot influent (settled/chlorinated) water contained $1.6 \pm 0.1 \mathrm{mg} / \mathrm{L}$ of DOC. In Spring and Summer months, all pilot filters were supplied with settled/chlorinated water, however influent chlorine was quenched prior to the biologically operated filters (BAF1 and BAF2). No difference was observed in DOC removals across either filters (Figure 5-6).

Raw water DOC values ranged between $2.2 \pm 0.2 \mathrm{mg} / \mathrm{L}$ and did not show seasonal variability, suggesting that the Fall turbidity spike events were primarily inorganic in nature. Coagulation with alum and settling achieved $30.6 \pm 4.5 \%$ reduction in DOC; subsequent filtration only contributed an additional $1.3 \pm 5.1 \%$ of DOC removal. The same trend was observed for the biologically operated filters which received raw water. Overall, none of the filters showed significant DOC ( $\mathrm{p}=0.05)$ with respect to their influents (Figure 5-6), irrespective of influent type.

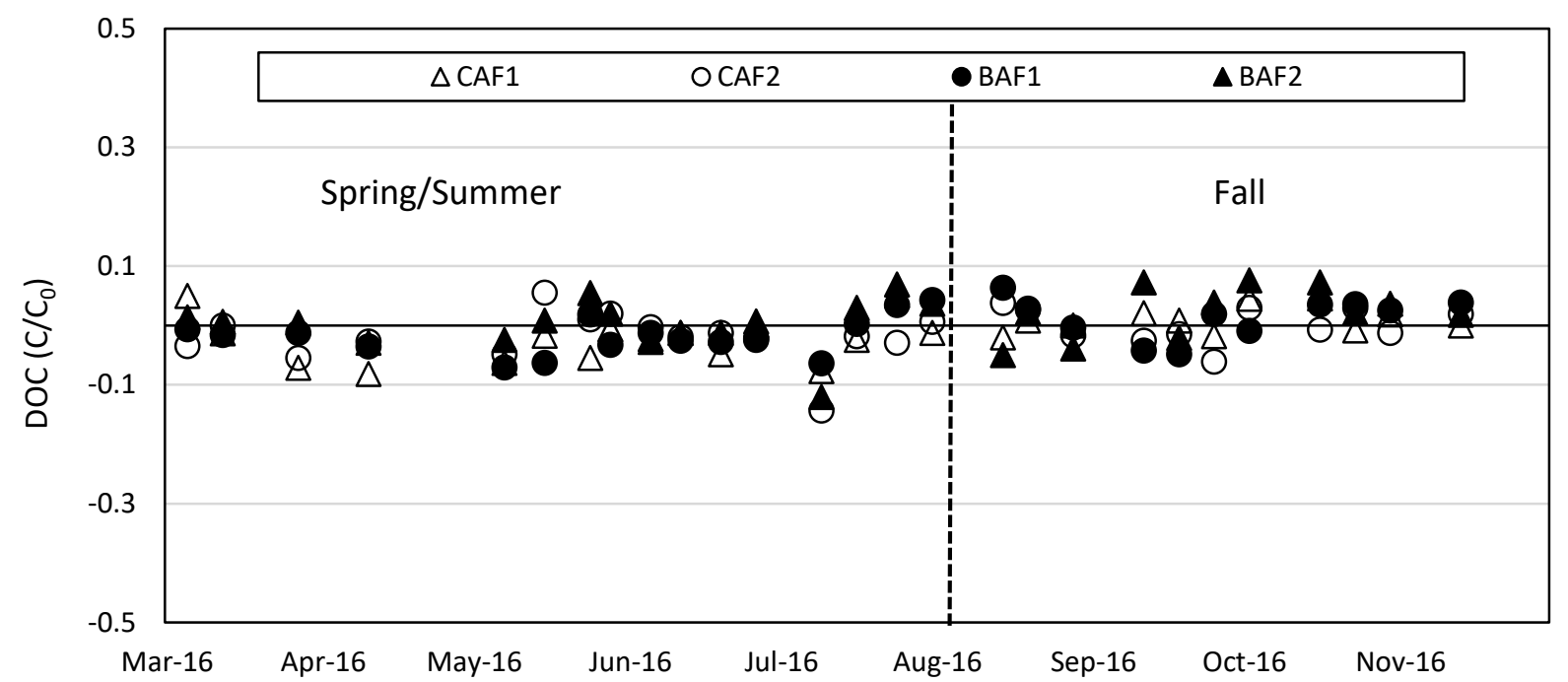

Figure 5-6: DOC fraction $(\mathrm{C} / \mathrm{C} 0)$ values for pilot-scale filter effluents. Note: BAF2 and CAF1 filters were switched to raw water during Fall months (August-November).

During Spring and the Summer months, average $\mathrm{UV}_{254}$ values for conventionally operated

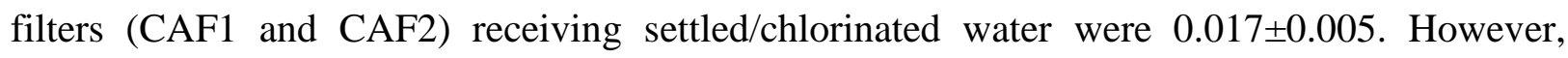
influent to biologically operated filters (BAF1 and BAF2) showed higher $\mathrm{UV}_{254}$ values $(0.023 \pm 0.014)$. It is possible that the quenching agent increased the $\mathrm{UV}_{254}$ for the quenched influent as colloidal particles, oxidants, and reducing agents (e.g., ozone, thiosulphate etc.) are capable of absorbing ultraviolet light at $\mathrm{UV}_{254}$ (APHA, 2012). However, little difference was observed when comparing effluents of biological $(0.012 \pm 0.013)$ and conventional $(0.015 \pm 0.012)$ filters during Spring and the Summer months (Figure 5-7). 
During the Fall operating period, raw water $\mathrm{UV}_{254}$ showed high variability $(0.128 \pm 0.109)$, while the settled water values were $0.022 \pm 0.009$ (Figure 5-7). These values were higher when compared to Spring and the Summer months reflecting the seasonal variability due to high turbidity events during the Fall months. Coagulation with alum and settling consistently removed $73.5 \pm 22.5 \%$ of the raw water $\mathrm{UV}_{254}$ and was more effective than direct biofiltration $(27.4 \pm 26.7 \%)$. No correlation was elucidated between $\mathrm{UV}_{254}$ and DOC values.

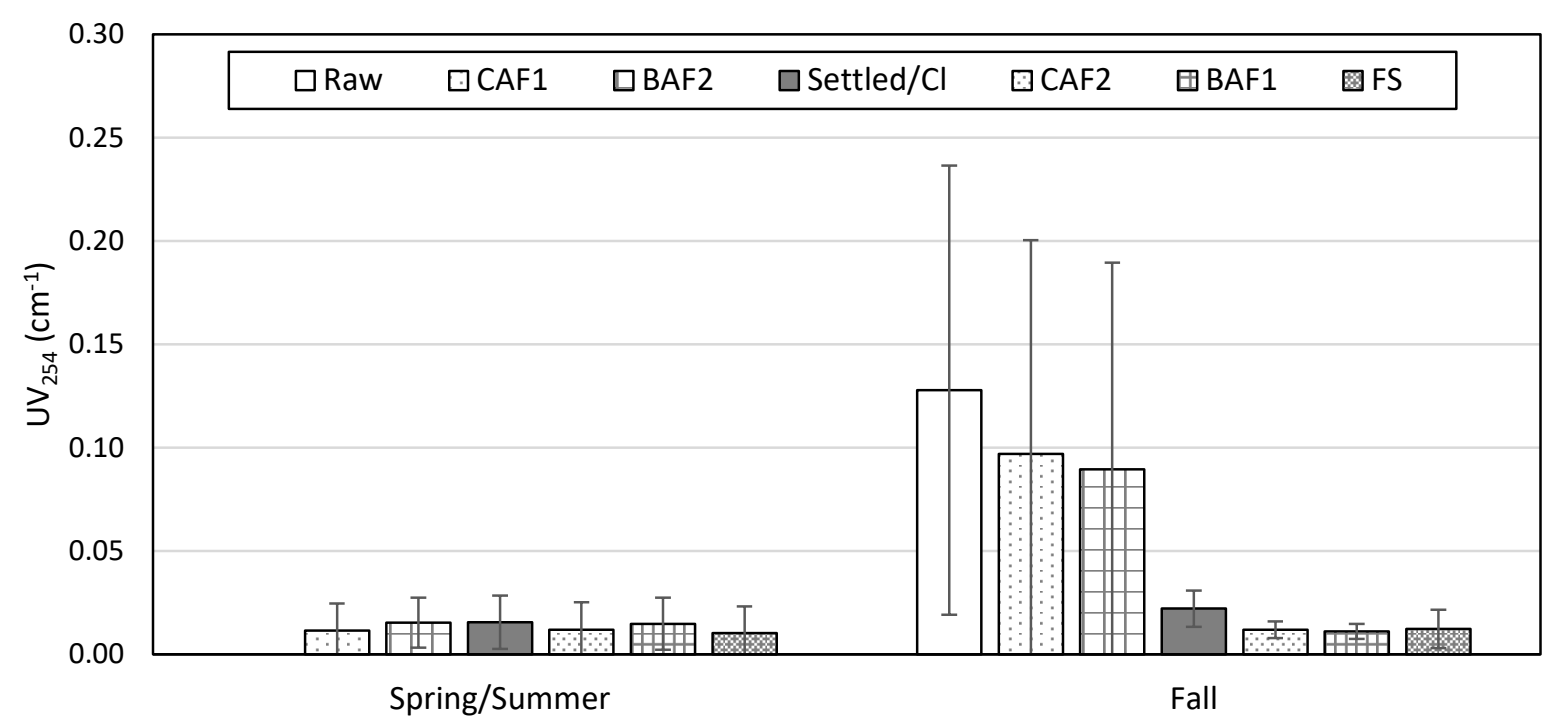

Figure 5-7: $\mathrm{UV}_{254}\left(\mathrm{~cm}^{-1}\right)$ values in raw water, influent and pilot and full-scale (FS) filter effluents. During Spring/Summer, filters received settled water, while during Fall months, CAF1 and BAF2 received raw water; $\mathrm{CAF} 2, \mathrm{BAF} 1$, and FS received settled/chlorinated water. Vertical bars represent one standard deviation (Spring/Summer, n=28; Fall, n=30).

\section{Disinfection By-Product Formation Potential (DBPFP)}

The impact of filtration on the formation potential of THMs and HAAs was determined by performing bench-scale chlorination tests $\left(1.5 \mathrm{mg} / \mathrm{L} \mathrm{Cl}_{2}\right.$ residual @ 24hrs) on influent and effluent samples (Figure 5-8 \& Figure 5-9). Raw water THMFP and HAAFP values were consistently low and ranged between $24.4 \pm 1.2 \mu \mathrm{g} / \mathrm{L}$ and $22.5 \pm 1.0 \mu \mathrm{g} / \mathrm{L}$, respectively; coagulation with alum and settling removed $4.9 \pm 1.6 \mu \mathrm{g} / \mathrm{L}$ of THMFP and $3.1 \pm 1.6 \mu \mathrm{g} / \mathrm{L}$ of HAAFP.

Full-scale and conventional pilot filters THMFP increased slightly (average of $1.7 \pm 1.3$ $\mu \mathrm{g} / \mathrm{L}$, and $1.1 \pm 2.9 \mu \mathrm{g} / \mathrm{L}$, respectively), showing good agreement between pilot and full-scale. Filters receiving settled-quenched influent (BAF1 and BAF2) reduced THMFP by an average of $0.6 \pm 2.9 \mu \mathrm{g} / \mathrm{L}$. Average settled/chlorinated HAAFP $(15.2 \pm 4.6 \mu \mathrm{g} / \mathrm{L})$ values were lower than THMFP $(22.1 \pm 3.1 \mu \mathrm{g} / \mathrm{L})$ during Spring and Summer months (Figure 5-9). Both full and pilot- 
scale filters either slighly increased or decreased the HAAFP and did not exhibit any trends (Figure 5-8 \& Figure 5-9). Benefits associated with biological filtration were not observed in terms of THMFP and HAAFP (Figure 5-9).

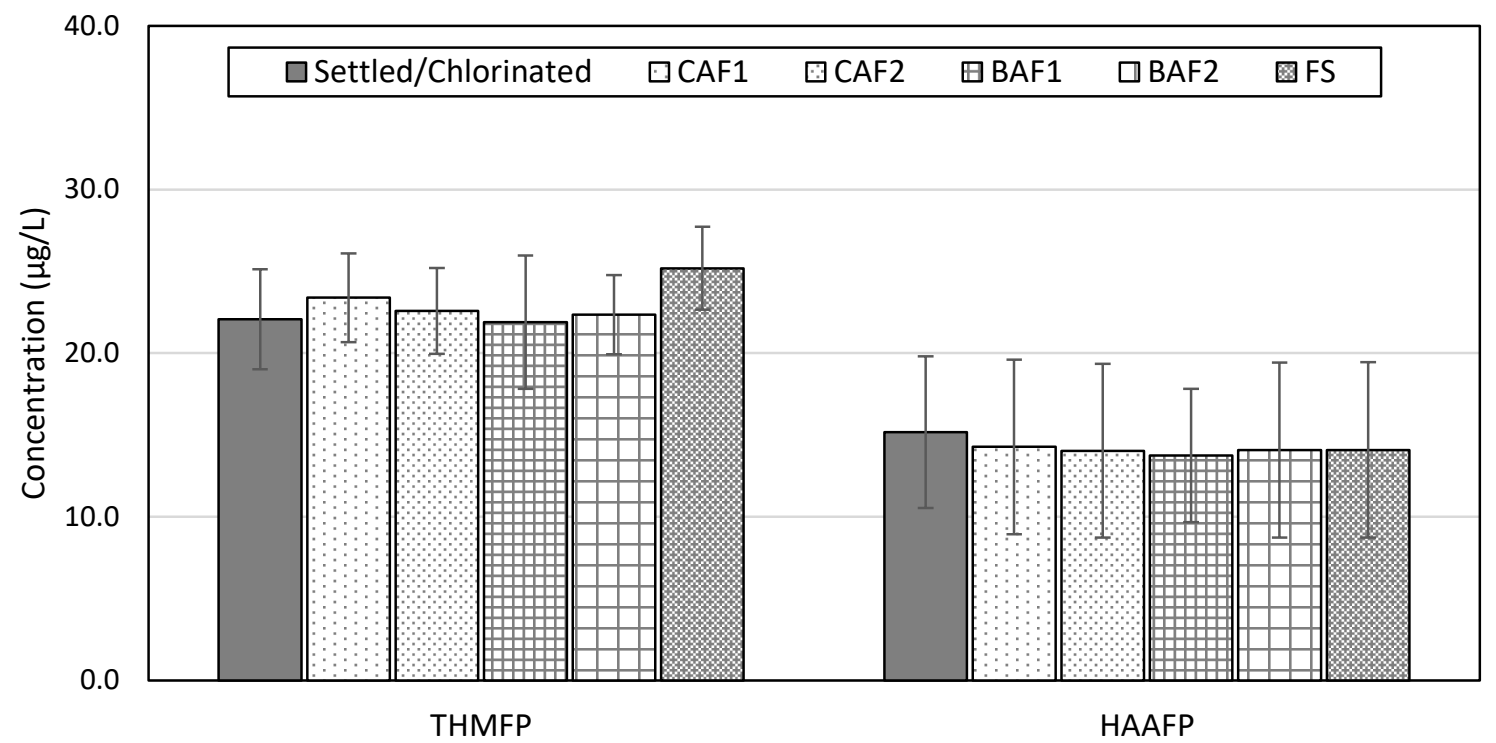

Figure 5-8: DBPFP $(\mu \mathrm{g} / \mathrm{L})$ for settled/chlorinated and effluents for pilot and full-scale (FS) filters during the Spring and the Summer months (March-August). CAF1, CAF2, and FS received settled/chlorinated water, while BAF1 and BAF2 received settled/quenched water. Vertical bars represent one standard deviation (THMFP, $n=12$; HAAFP, $n=10$ ).

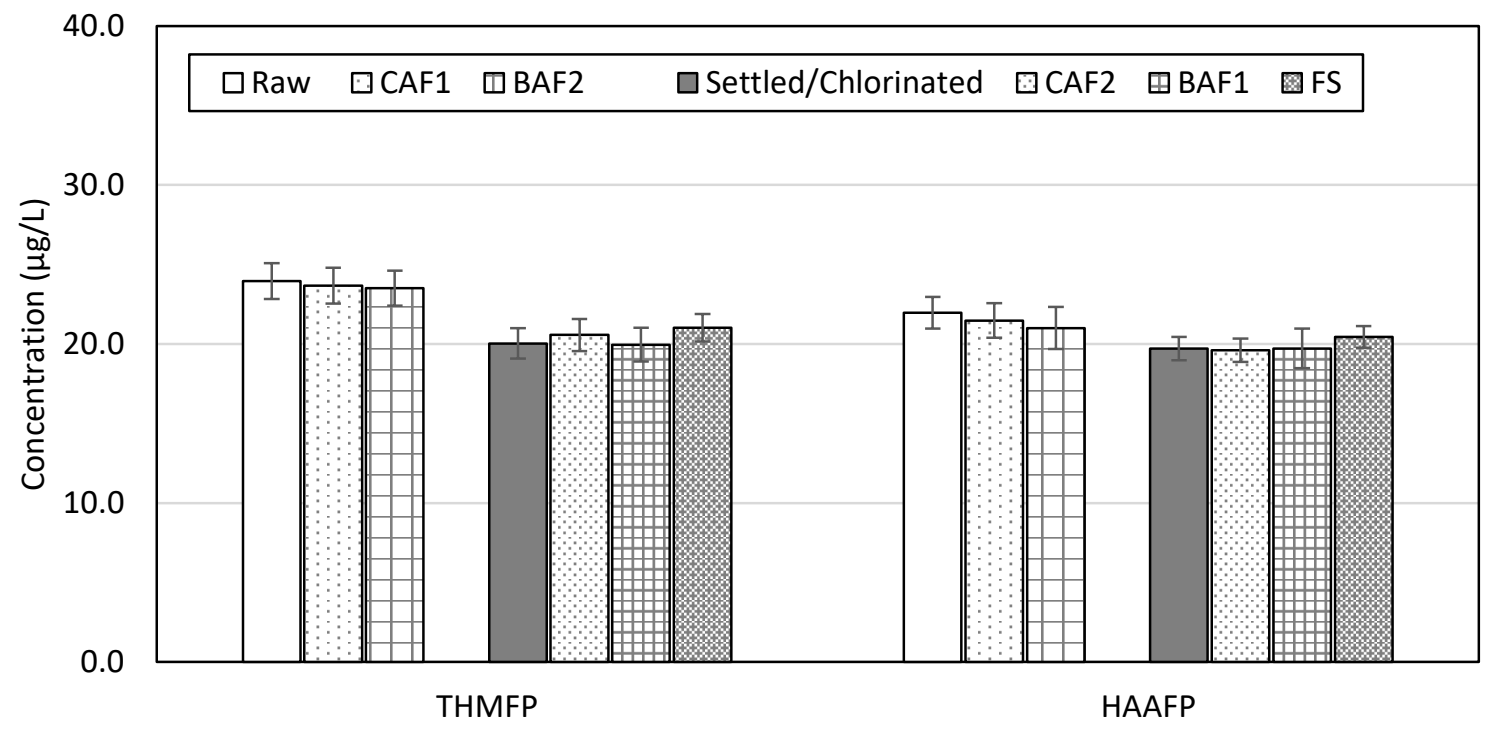

Figure 5-9: DBPFP $(\mu \mathrm{g} / \mathrm{L})$ for the raw, settled/chlorinated, and effluent for pilot and full-scale (FS) filters during the Fall months (August-November). Note: CAF1 and BAF2 received raw water, while CAF2, BAF1, and FS received settled/chlorinated water. Vertical bars represent one standard deviation $(n=4)$. 


\subsubsection{Turbidity Removal}

Seasonal turbidity fluctuations are common ranging from 0.5 to 1000 NTUs (average $=50$ NTU, $95^{\text {th }}$ percentile $\left.=200\right)$ in the Fall months, have been attributed to the shallow depth $(\sim 19$ $64 \mathrm{~m}$ ) of the Lake Erie and sandy bed (Awde et al., 2014) during periods of high winds. A key objective of this study was to evaluate the potential benefit of biofiltration to mitigate turbidity events. During Spring and Summer months, filter influent (post-settling) values were 1.39 \pm 0.69 NTU; consequently, all pilot filters effluents had consistent, low turbidity values $(0.17 \pm 0.05$ NTU) (Figure 5-10). No statistical difference $(\mathrm{p}=0.05)$ was observed among the four filters.

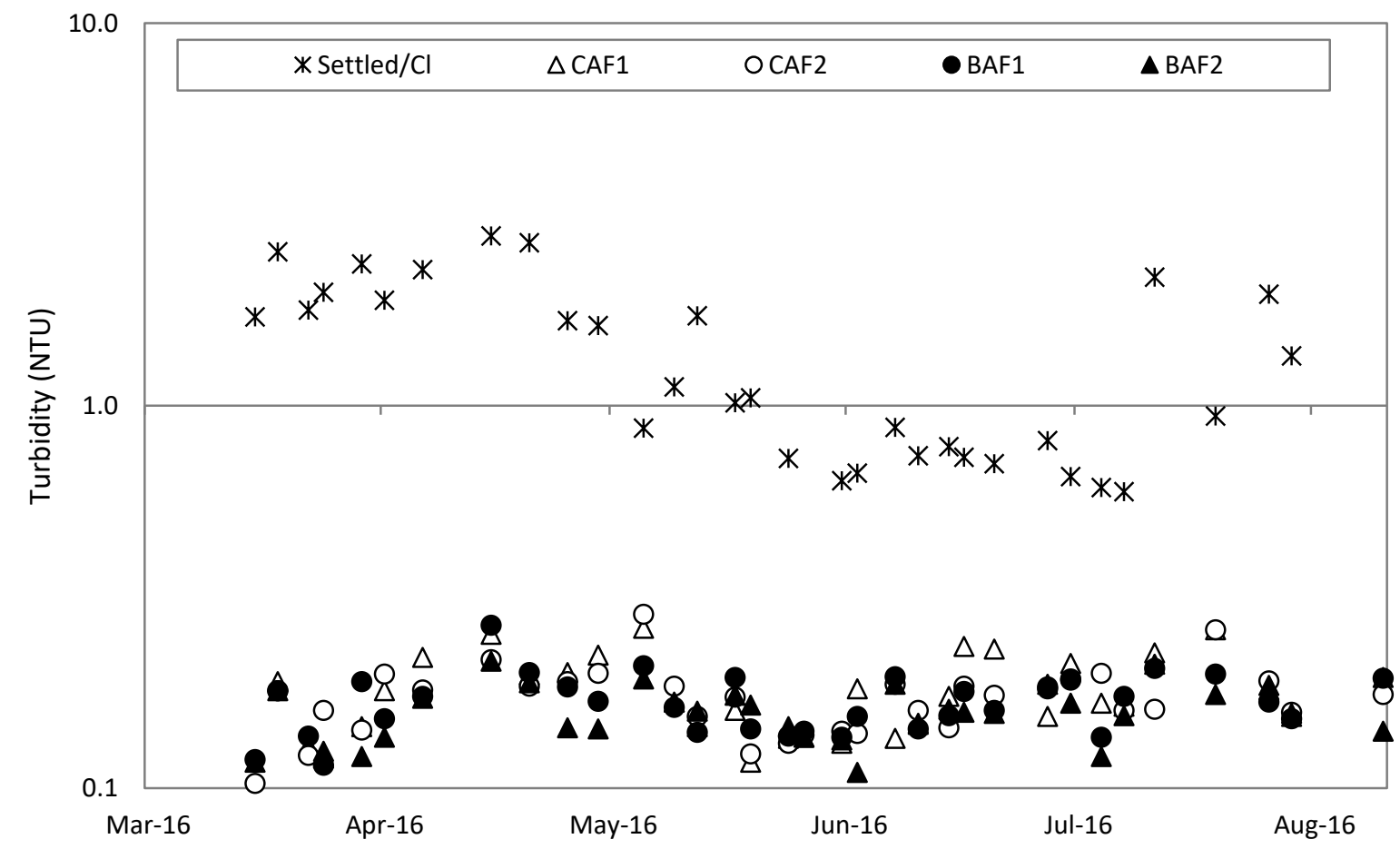

Figure 5-10: Spring and Summer Turbidity (NTU) values for pilot influent (settled/chlorinated) and effluents. Note that turbidity is plotted on a logarithmic scale.

During the Fall (August-November), settled water turbidity water ranged from 1.1 -17.4 NTU (Appendix Table 8-8), while raw water was significantly higher $(\mathrm{p}=0.05)$ and ranged between 1.0-98.6 NTU (Figure 5-11). The biologically operated filter, BAF1 (0.21 \pm 0.01 NTU), performed significantly $(\mathrm{p}=0.05)$ better than the conventionally operated filter, CAF2 $(0.41 \pm 0.07$ NTU). These results indicate that biofiltration can mitigate turbidity events. In contrast, filters receiving raw water, $\mathrm{CAF} 1$ and $\mathrm{BAF} 2$, reduced influent turbidity by 50-58\% (Figure 5-11). 


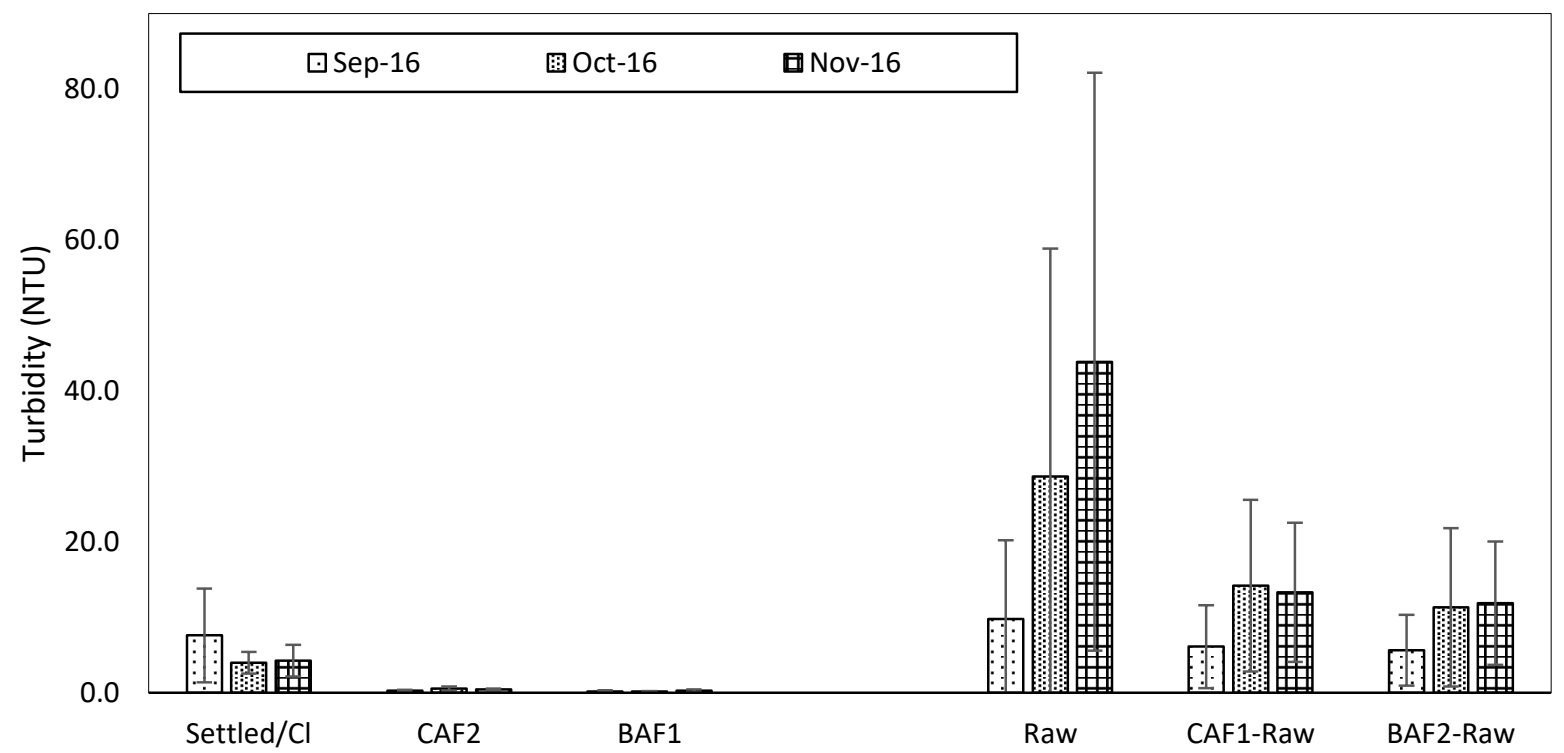

Figure 5-11: Fall turbidity (NTU) values for raw, settled water, and pilot filter effluents. Note that $\mathrm{CAF} 1$ and $\mathrm{BAF} 2$ received raw water. Vertical bars represent one standard deviation (September, $\mathrm{n}=8$; October, $\mathrm{n}=8$; November, $\mathrm{n}=9$ ).

\subsubsection{Headloss Buildup}

Headloss profiles for each filter between periods of backwash are shown in Figure 5-12.

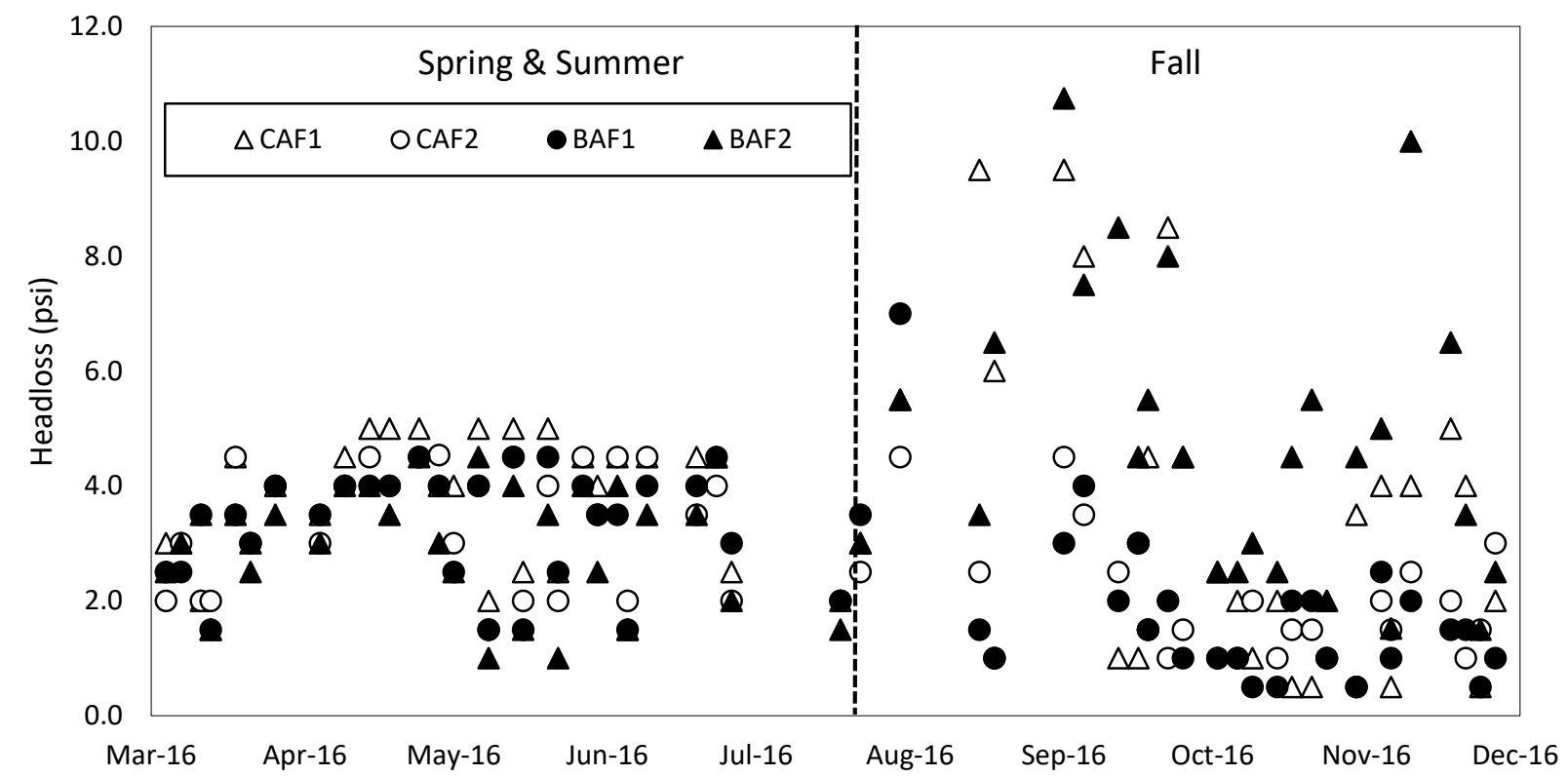

Figure 5-12: Headloss (psi) values for the pilot-scale filters. Note that CAF1 and BAF2 received raw water during the Fall months (August-November). 
During Spring and the Summer months, the rate of headloss development was identical between the four filters, at a rate of 0.34-1.36 psi/day. No difference in headloss development was observed, with or without the application of quenching agent (calcium thiosulphate, CTS).

When two filters were switched from settled/chlorinated to raw water (CAF1 and BAF2), headloss developed at a faster rate due to high turbidity values during the Fall months (Figure 5-12). As such, backwash frequency was increased to 3 days instead of 4 to maintain flow rate.

\subsection{Summary}

It was difficult to encourage microbial colonization on anthracite filters using settled/chlorinated/quenched influent water. However, the biologically operated filters accumulated active biomasses when fed with raw water. Perhaps coagulation removed essential nutrients and endogenous bacteria or the application of pre-filter chlorination effectively killed any remaining bacteria in influent water. The biological anthracite filters and conventional treatment effectively removed manganese and iron. However, shifts in water chemistry and extreme turbidity events contributed to manganese leaching from the biological filters. Moreover, biologically operated filter performed better than conventional filters in terms of turbidity reduction; no differences in DOC and DBPFP removals were observed.

\subsection{Conclusions}

- Conventional treatment (coagulation with alum and settling followed by non-biological filtration) consistently removed both $\mathrm{Mn}$ and Fe levels to below $10 \mu \mathrm{g} / \mathrm{L}$.

- Shifts in water chemistry $(\triangle \mathrm{pH}=0.4)$ and extreme turbidity events (1.0-98.6 NTU) contributed to manganese leaching $(\sim 100-600 \mu \mathrm{g} / \mathrm{L})$ from the biological filters. One possible explanation for manganese release is the displacement of anthracite-bound $\mathrm{Mn}(\mathrm{IV}) / \mathrm{Mn}(\mathrm{II})$ by $\mathrm{Fe}(\mathrm{III})$ as evidenced from iron removals to below $300 \mu \mathrm{g} / \mathrm{L}$ across the biofilters.

- In terms of DOC and DBPFP removals, no significant $(\mathrm{p}=0.05)$ differences were observed between conventional and biologically operated anthracite filters.

- Future studies at the pilot-scale with nutrient enhancement, manganese oxidising bacteria (MnOB) inoculum coupled with microbial identification would help to pinpoint the mechanism behind manganese removal and optimize biofiltration performance. 


\section{Overall Summary, Conclusions, and Recommendations}

\subsection{Summary}

Pilot plant operation at the Lake Ontario pilot compared the performance of an engineered ceramic media to conventional media (GAC and anthracite) as a potential biological media. Overall, the ceramic media was a good alternative to anthracite in term of biological accumulation and organic carbon removal, especially in cold-water conditions $\left(\mathrm{T}<10^{\circ} \mathrm{C}\right)$. However, biological granular activated carbon (GAC) was superior in terms of dissolved organic carbon (DOC) and disinfection by-product formation potential (DBPFP) removal.

At the Lake Erie pilot, biofilters were compared to conventional anthracite filters for both inorganic (manganese and iron) and organic removals (DOC and DBPFP). The biological anthracite filters and conventional treatment effectively removed manganese and iron. However, it was observed that shifts in water chemistry $(\triangle \mathrm{pH}=0.4)$ and extreme turbidity events $(1.0-98.6$ NTU) contributed to manganese leaching from the biological filters. No significant difference $(\mathrm{p}=0.05)$ in organic removal (DOC or DBPFP) was observed.

\subsection{Conclusions}

The main conclusions that can be drawn from the Lake Ontario pilot-scale study are:

- Biological GAC had higher removal of DOC (9.8 $\pm 3.8 \%)$, THMFP $(26.3 \pm 10.2 \%)$, and HAAFP $(27.2 \pm 14.0 \%)$ when compared to the other media types examined $(\mathrm{p}>0.05)$.

- CER media required 6-7 months to biologically acclimate, while the GAC and anthracite filters were biologically active (>100 ng of ATP /g of media) within 2-3 months of operation. Once acclimated, ATP values of 243 and $208 \mathrm{ng} / \mathrm{g}$ were attained for CER 1.0 and 1.2, respectively. These values were statistically comparable to GAC ( $244 \mathrm{ng} / \mathrm{g})$ and higher than anthracite (110 ng/g), however did not translate into greater organics (DOC and DBPFP) removal.

- Esterase and laccase enzyme kinetics were highest for GAC, while CER was shown to have greater biodegradation potential than anthracite. 
- The four media attained similar turbidity reduction ( $\mathrm{p}>0.05$ ), however it is estimated that ceramic media filters can achieve 1.5-2.3 times longer filter run times than anthracite, which could represent potential cost savings in terms of energy and water requirements.

- Overall, ceramic media was shown to be a potential alternative to anthracite for biofiltration operating in colder water conditions $\left(\mathrm{T}<10^{\circ} \mathrm{C}\right)$.

The results from the Lake Erie pilot-scale biofiltration study yielded the following conclusions:

- Conventional treatment (coagulation with alum and settling followed by non-biological filtration) consistently removed both $\mathrm{Mn}$ and Fe levels to below $10 \mu \mathrm{g} / \mathrm{L}$.

- It was difficult to achieve an active biofilm on biofilters (>100 ng ATP/g media) with quenched settled water even after 150 days of filter operation; however, once switched to raw water, filters developed an active biomass $(117 \pm 37 \mathrm{ng} \mathrm{ATP} / \mathrm{g})$ within 45 days of filter operation. Perhaps the coagulation process was removing essential nutrients or the prefilter chlorine residuals was effectively preventing microbial growth on the filter media.

- Shifts in water chemistry $(\triangle \mathrm{pH}=0.4)$ and extreme turbidity events $(1.0-98.6 \mathrm{NTU})$ contributed to leaching of accumulated manganese $(70-390 \mu \mathrm{g} / \mathrm{L})$ from biofilters. It is possible that manganese release is attributed to displacement of anthracite-bound $\mathrm{Mn}(\mathrm{IV}) / \mathrm{Mn}$ (II) by Fe(III) as evident from iron removals to below $300 \mu \mathrm{g} / \mathrm{L}$ across biofilters.

- In terms of DOC and DBPFP removals, no significant $(\mathrm{p}=0.05$ ) differences were observed between conventional and biologically operated anthracite filters.

\subsection{Recommendations}

- While ceramic media was shown to be a suitable alternative to anthracite in cleaner source water (turbidity $<1 \mathrm{NTU}$; DOC $<2.3 \mathrm{mg} / \mathrm{L}$ ), further studies are required in high organic (DOC $>3 \mathrm{mg} / \mathrm{L}$ ) and turbid (>1 NTU) source waters to better assess the overall performance of ceramic media. 
- This study provided a qualitative discussion for the microbial adhesion on the different media surfaces. Future microbial community analyses should be performed to better understand the differences in composition and preferences for biofilm attachment.

- Future studies with ceramic media as a tri-media top layer $(10-15 \mathrm{~cm})$ for dual-media filters are recommended to improve filter run times.

- It was difficult to achieve active, acclimated biofilm on the biofilters (> $100 \mathrm{ng} \mathrm{ATP/g}$ media). To accelerate the acclimation time for biofilters, future optimization studies including, nutrient enrichment, $\mathrm{pH}$ adjustment, and manganese/iron oxidising bacteria inoculum are required.

- The presence of manganese oxidizing bacteria $(\mathrm{MnOB})$ on the biological filter media should be routinely tested along with the impact of stress conditions (shifts in water chemistry, turbidity spikes, and ORP) to minimize Mn breakthrough and optimize biofiltration for Mn removal.

- Since Mn and Fe levels may be highly variable throughout the year due to seasonal factors, frequent monitoring (2-3 times/week) is recommended during turbidity spikes. Additional data points could be further used to elucidate underlying trends, predict future spike events, and manage biofiltration $\mathrm{Mn}$ and Fe removal expectations. 


\section{References}

Aksoğan, S., Baştürk, A., Yüksel, E., Akgiray, O., 2004. On the use of crushed shells of apricot stones as the upper layer in dual media filters. Water Sci. Technol. 48, 497-503.

Aktaş, Ö., Çeçen, F., 2007. Bioregeneration of activated carbon: A review. Int. Biodeterior. Biodegrad. 59, 257-272. doi:10.1016/j.ibiod.2007.01.003

APHA, 2012. Standard Methods for the Examination of Water and Wastewater. Stand. Methods 541.

Awde, N., Yu, Z., Gemin, J., Breese, S., Lima, B., 2014. Elgin Area Water Treatment Plant Design of a Residuals Management Facility for Varying Raw Water Conditions, in: OWWA/OMWA Joint Annual Conference 2014. pp. 1-13.

Azzeh, J., Taylor-Edmonds, L., Andrews, R.C., 2015. Engineered biofiltration for ultrafiltration fouling mitigation and disinfection by-product precursor control. Water Sci. Technol. Water Supply 15, 124. doi:10.2166/ws.2014.091

Babi, K.G., Koumenides, K.M., Nikolaou, a. D., Makri, C. a., Tzoumerkas, F.K., Lekkas, T.D., 2007. Pilot study of the removal of THMs, HAAs and DOC from drinking water by GAC adsorption. Desalination 210, 215-224. doi:10.1016/j.desal.2006.05.046

Barloková, D., Ilavský, J., 2010. Removal of Iron and Manganese from Water Using Filtration by Natural Materials. Polish J. Environ. Stud. 19, 1117-1122. doi:10.1109/MACE.2010.5536419

Biswas, N., Arbuckle, W.B., Hajra, M.G., 2003. Polyurethane foam filter/ PAC ADSORBER. J. Am. Water Works Assoc. 95:5, 183-188.

Black, K.E., Bérubé, P.R., 2014. Rate and extent NOM removal during oxidation and biofiltration. Water Res. 52, 40-50. doi:10.1016/j.watres.2013.12.017

Bond, T., Goslan, E.H., Jefferson, B., Roddick, F., Fan, L., Parsons, S. a., 2009. Chemical and biological oxidation of NOM surrogates and effect on HAA formation. Water Res. 43, 2615- 
2622. doi:10.1016/j.watres.2009.03.036

Bose, P., Reckhow, D. a., 2007. The effect of ozonation on natural organic matter removal by alum coagulation. Water Res. 41, 1516-1524. doi:10.1016/j.watres.2006.12.027

Bouchard, M.F., Sauvé, S., Barbeau, B., Legrand, M., Brodeur, M.È., Bouffard, T., Limoges, E., Bellinger, D.C., Mergler, D., 2011. Intellectual impairment in school-age children exposed to manganese from drinking water. Environ. Health Perspect. 119, 138-143. doi:10.1289/ehp.1002321

Brandhuber, P., Craig, S., Friedman, M., Hill, A., Booth, S., Amie, H., 2015. Legacy of Manganese Accumulation in Water Systems.

Burger, M.S., Mercer, S.S., Shupe, G.D., Gagnon, G.A., 2008. Manganese removal during benchscale biofiltration. Water Res. 42, 4733-4742. doi:10.1016/j.watres.2008.08.024

Cai, Y., Li, D., Liang, Y., Luo, Y., Zeng, H., Zhang, J., 2015. Effective start-up biofiltration method for Fe, Mn, and ammonia removal and bacterial community analysis. Bioresour. Technol. 176, 149-155. doi:10.1016/j.biortech.2014.11.025

Calgon Carbon, 2012. Filtrasorb @ 300 [Product Bulletin]. http://www.calgoncarbon.com/wpcontent/uploads/product-literature/24_Filtrasorb_300M_1019web.pdf.

Carlson, K.H., Amy, G.L., 1998. BOM removal during biofiltration. J. / Am. Water Work. Assoc. $90,42-52$.

Çeçen, F., Aktaş, Ö., 2011. Removal of NOM , Nutrients , and Micropollutants in BAC Filtration.

Chaiket, T., Singer, P.C., Miles, A., Moran, M., Pallotta, C., 2002. Effectiveness of coagulation, ozonation, and biofiltration in controlling DBPs. J. / Am. Water Work. Assoc. 94, 81-95.

Chen, B., Westerhoff, P., 2010. Predicting disinfection by-product formation potential in water. Water Res. 44, 3755-3762. doi:10.1016/j.watres.2010.04.009

Chen, C., Zhang, X., He, W., Lu, W., Han, H., 2007. Comparison of seven kinds of drinking water 
treatment processes to enhance organic material removal: a pilot test. Sci. Total Environ. 382, 93-102. doi:10.1016/j.scitotenv.2007.04.012

Chen, C., Zhang, X., Zhu, L., He, W., Han, H., 2011. and Advanced Treatment Je Sc Sc. J. Environ. Sci. 23, 582-586.

Chien, C.C., Kao, C.M., Chen, C.W., Dong, C.D., Wu, C.Y., 2008. Application of biofiltration system on AOC removal: Column and field studies. Chemosphere 71, 1786-1793. doi:10.1016/j.chemosphere.2007.12.005

Davies, P.D., Wheatley, A.D., 2012. Pilot plant study of alternative filter media for rapid gravity filtration. Water Sci. Technol. 66, 2779-2784. doi:10.2166/wst.2012.517

Delatolla, R., Séguin, C., Springthorpe, S., Gorman, E., Campbell, a., Douglas, I., 2015. Disinfection byproduct formation during biofiltration cycle: Implications for drinking water production. Chemosphere 136, 190-197. doi:10.1016/j.chemosphere.2015.05.001

Diem, D., Stumm, W., 1984. Is dissolved Mn2+ being oxidized by O2 in absence of Mn-bacteria or surface catalysts? Geochim. Cosmochim. Acta 48, 1571-1573. doi:10.1016/00167037(84)90413-7

Dimas, B.N., 2016. Assessing Biofilm on Biofilter Media (Granular Activated Carbon and Anthracite) from a Pilot Scale Drinking Water Treatment Plant. (Master's Thesis). Ryerson University, Toronto, ON. http://digital.library.ryerson.ca/islandora/object/RULA\%3A4904.

Dixon, D., Anderson, N., Bolto, B., Chiswell, B., Sly, L., Hurse, T., Craig, K., Hamilton, G., Hutchinson, B., West, C., Wooley, R., 2006. The removal of manganese from drinking waters : Research Report No. 26. doi:10.1080/5908555828

Dussert, B.W., Tramposch, W.G., 1997. Impact of Support Media on the Biological Treatment of Ozonated Drinking Water. Sci. Eng. 19, 97-108. doi:10.1080/01919519708547308

Edzwald, J.K., Tobiason, J.E., 1999. Enhanced coagulation: US requirements and a broader view. Water Sci. Technol. Water Supply 40, 63-70. 
Emelko, M.B., Huck, P.M., Coffey, B.M., Smith, E.F., 2006. Effects of media, backwash, and temperature on full-scale biological filtration. Am. Water Work. Assoc. 98, 61-73.

Evans, P.J., Smith, J.L., Lechevallier, M.W., Schneider, O.D., Weinrich, L. a., Jjemba, P.K., 2013. Biological Filtration Monitoring and Control Toolbox: Guidance Manual.

Fonseca, A.C., Scott Summers, R., Hernandez, M.T., 2001. Comparative measurements of microbial activity in drinking water biofilters. Water Res. 35, 3817-3824. doi:10.1016/S0043-1354(01)00104-X

French, D., 2012. Granular filter media: Evaluating filter bed depth to grain size ratio. Filtr. Sep. 49, 34-36. doi:10.1016/S0015-1882(12)70246-X

Gabelich, C.J., Gerringer, F.W., Lee, C.C., Knocke, W.R., 2006. Sequential manganese desorption and sequestration in anthracite coal and silica sand filter media. J. / Am. Water Work. Assoc. 98, 116-127.

Gabelich, C.J., Knocke, W.R., Coffey, B.M., Johnston, R., Do, H., Mofidi, A.A., 2005. Manganese Desorption from Filter Media: Experiences with Biological Filtration, in: American Water Works Association. pp. 1-20.

Gibert, O., Lefèvre, B., Fernández, M., Bernat, X., Paraira, M., Pons, M., 2013. Fractionation and removal of dissolved organic carbon in a full-scale granular activated carbon filter used for drinking water production. Water Res. 47, 2821-2829. doi:10.1016/j.watres.2013.02.028

Granger, H.C., Stoddart, A.K., Gagnon, G.A., 2014. Direct biofiltration for manganese removal from surface water. J. Environ. Eng. 140, 1-8. doi:10.1061/(ASCE)EE.1943-7870.0000819.

Hakes, L.S., Evans, A., Caroline, R., Knocke, B., Ziv-El, M., Keuthly, S., Kirisits, M.J., 2016. Troubleshooting Reduced Biofilter Manganese Removal Following Winter Shutdowns, in: AWWA WQTC Conference Proceedings.

Hallé, C., 2009. Biofiltration in drinking water treatment: Reduction of membrane fouling and biodegradation of organic trace contaminants 1-349. 
Hammes, F., Goldschmidt, F., Vital, M., Wang, Y., Egli, T., 2010. Measurement and interpretation of microbial adenosine tri-phosphate (ATP) in aquatic environments. Water Res. 44, 3915-3923. doi:10.1016/j.watres.2010.04.015

Health Canada, 2012. Guidelines for Canadian Drinking Water Quality Summary Table Prepared by the Federal-Provincial-Territorial Committee on Drinking Water of the FederalProvincial-Territorial Committee on Health and the Environment March 2006. Environments 1-16.

Health Canada, 2008. Guidelines for Canadian Drinking Water Quality: Guideline Technical Document-Haloacetic Acids. doi:10.1016/j.scitotenv.2009.04.006

Health Canada, 2006. Guidelines for Canadian Drinking Water Quality: Guideline Technical Document- Trihalomethanes.

Hogg, S., 2013. Essential Microbiology Second Edition. 2013 John Wiley \& Sons, Ltd.

Hozalski, R., Bouwer, E., Goel, S., 1999. Removal of natural organic matter (NOM) from drinking water supplies by ozone-biofiltration. Water Sci. Technol. doi:10.1016/S02731223(99)00652-6

Hrudey, S.E., 2009. Chlorination disinfection by-products, public health risk tradeoffs and me. Water Res. 43, 2057-2092. doi:10.1016/j.watres.2009.02.011

Hu, J.Y., Wang, Z.S., Ng, W.J., Ong, S.L., 1999. The effect of water treatment processes on the biological stability of potable water. Water Res. 33, 2587-2592. doi:10.1016/S00431354(98)00482-5

Huck, P.M., Sozaski, M.M., 2008. Biological filtration for membrane pre-treatment and other applications: towards the development of a practically-oriented performance parameter. J. Water Supply Res. Technol. - Aqua 57, 203 LP-224.

Humby, M.S., Fitzpatrick, C.S.B., 1996. Attrition of granular filter media during backwashing with combined air and water. Water Res. 30, 291-294. doi:10.1016/0043-1354(95)00177-8 
Katsoyiannis, I.A., Zouboulis, A.I., 2004. Biological treatment of Mn(II) and Fe(II) containing groundwater: Kinetic considerations and product characterization. Water Res. 38, 19221932. doi:10.1016/j.watres.2004.01.014

Khadse, G.K., Lande, V.W., Andey, S.P., Labhasetwar, P.K., 2013. Performance of Up-Flow Roughing Biofilter in Iron Removal from Groundwater 2, 9-14.

Kitis, M., Kaplan, S.S., Karakaya, E., Yigit, N.O., Civelekoglu, G., 2007. Adsorption of natural organic matter from waters by iron coated pumice. Chemosphere 66, 130-138. doi:10.1016/j.chemosphere.2006.05.002

Knappe, D.R.U., Belk, C.R., Briley, D.S., Gandy, S.R., Rastogi, N., Rike, A.H., Glasgow, H., Hannon, E., Frazier, William, D., Kohl, P., Pugsley, S., 2004. Algae Detection and Removal Strategies for Drinking Water Treatment Plants.

Knocke, W.R., Occiano, S.C., Hungate, R., 1991. Removal of soluble manganese by oxide-coated filter media. Sorption rate and removal mechanism issues. J. / Am. Water Work. Assoc. 83, 64-69. doi:10.2307/41293529

Kohl, P.M., Dixon, D., 2012. Occurrence, impacts, and removal of manganese in biofiltration processes 2, 1-189.

Konieczny, K., Sąkol, D., Płonka, J., Rajca, M., Bodzek, M., 2009. Coagulation-ultrafiltration system for river water treatment. Desalination 240, 151-159. doi:10.1016/j.desal.2007.11.072

Korotta-Gamage, S.M., Sathasivan, A., 2017. A review: Potential and challenges of biologically activated carbon to remove natural organic matter in drinking water purification process. Chemosphere 167, 120-138. doi:10.1016/j.chemosphere.2016.09.097

Krasner, S.W., Weinberg, H.S., Richardson, S.D., Pastor, S.J., Chinn, R., Sclimenti, M.J., Onstad, G.D., Thruston, A.D., 2006. The Occurrence of a New Generation of Disinfection ByProducts. Environ. Sci. Technol. 40, 7175-7185. 
Kuehn, W., Mueller, U., 2000. Riverbank filtration: An overview. J. / Am. Water Work. Assoc. $92,60-69$.

Lauderdale, C., Chadik, P., Kirisits, M.J., Brown, A.J., 2012. Engineered biofiltration: Enhanced biofilter performance through nutrient and peroxide addition. J. Am. Water Works Assoc. 104, 298-309. doi:10.5942/jawwa.2012.104.0073

Lautenschlager, K., Hwang, C., Ling, F., Liu, W.T., Boon, N., Köster, O., Egli, T., Hammes, F., 2014. Abundance and composition of indigenous bacterial communities in a multi-step biofiltration-based drinking water treatment plant. Water Res. 62, 40-52. doi:10.1016/j.watres.2014.05.035

Lechevallier, M.W., Becker, W.C., Schorr, P., Lee, R.G., 1992. Evaluating the Performance of Biologically Active Rapid Filters. Am. Water Work. Assoc. 84, 136-146.

Li, D., Zhang, J., Wang, H., Yang, H., Wang, B., 2005. Operational performance of biological treatment plant for iron and manganese removal. J. Water Supply Res. Technol. - Aqua 54, 15 LP-24.

Liu, X., Huck, P.M., Slawson, R.M., 2001. Factors Affecting Drinking Water Biofiltration. J. / Am. Water Work. Assoc. 93, 90-101. doi:10.1016/j.cis.2010.06.007

Lou, J.C., Chang, C.J., Chen, W.H., Tseng, W. Bin, Han, J.Y., 2014. Removal of trihalomethanes and haloacetic acids from treated drinking water by biological activated carbon filter. Water. Air. Soil Pollut. 225. doi:10.1007/s11270-013-1851-3

Lou, J.C., Chang, T.W., Huang, C.E., 2009. Effective removal of disinfection by-products and assimilable organic carbon: An advanced water treatment system. J. Hazard. Mater. 172, 1365-1371. doi:10.1016/j.jhazmat.2009.07.151

Magic-Knezev, A., van der Kooij, D., 2004. Optimisation and significance of ATP analysis for measuring active biomass in granular activated carbon filters used in water treatment. Water Res. 38, 3971-3979. doi:10.1016/j.watres.2004.06.017 
Matilainen, A., Sillanpää, M., 2010. Removal of natural organic matter from drinking water by advanced oxidation processes. Chemosphere 80, 351-365. doi:10.1016/j.chemosphere.2010.04.067

McKie, M.J., Taylor-edmonds, L., Andrews, S.A., Andrews, R.C., 2015. Engineered biofiltration for the removal of disinfection by-product precursors and genotoxicity. Water Res. 81, 196207. doi:10.1016/j.watres.2015.05.034

Melin, E.S., Bohne, R. a., Sjøvold, F., Ødegaard, H., 2000. Treatment of ozonated water in biofilters containing different media. Water Sci. Technol. 41, 57-60.

Melin, E.S., Odegaard, H., 2000. The effect of biofilter loading rate on the removal of organic ozonation by-products. Water Res. 34, 4464-4476. doi:10.1016/S0043-1354(00)00204-9

Melin, E.S., Ødegaard, H., 1999. Biofiltration of Ozonated Humic Water in Expanded Clay Aggregate Filter. Water Sci. Technol. 40, 165-172. doi:10.1016/S0273-1223(99)00653-8

Mills, C.J., Bull, R.J., Cantor, K.P., Reif, J., Hrudey, S.E., Huston, P., 1998. Health Risks of Drinking Water Chlorination By-products: Report of an Expert Working Group. Chronic Dis. Can. 19, 91-102.

Miltner, R.J., Summers, R.S., Wang, J.Z., 1995. Biofiltration performance: part 2, effect of backwashing. J. / Am. Water Work. Assoc. 87, 64-70.

Moll, D.M., Summers, R.S., Fonseca, A.C., Matheis, W., 1999. Impact of Temperature on Drinking Water Biofilter Performance and Microbial Community Structure. Environ. Sci. Technol. 33, 2377-2382. doi:10.1021/es9900757

Mouchet, P., 1992. From conventional to biological removal of iron and manganese in France. J. / Am. Water Work. Assoc. 84, 158-167.

Niquette, P., Prévost, M., Servais, P., Beaudet, J.F., Coallier, J., Lafrance, P., 1998. Shutdown of BAC filters: Effects on water quality. J. / Am. Water Work. Assoc. 90, 53-61.

Nybroe, O., Jørgensen, P.E., Henze, M., 1992. Enzyme activities in waste water and activated 
sludge. Water Res. 26, 579-584. doi:10.1016/0043-1354(92)90230-2

Ohkouchi, Y., Ly, B.T., Ishikawa, S., Aoki, Y., Echigo, S., Itoh, S., 2011. A survey on levels and seasonal changes of assimilable organic carbon (AOC) and its precursors in drinking water. Environ. Technol. 32, 1605-1613. doi:10.1080/09593330.2010.545439

Percival, S.L., Knapp, J.S., Wales, D.S., Edyvean, R.G.J., 1999. The effect of turbulent flow and surface roughness on biofilm formation in drinking water. J. Ind. Microbiol. Biotechnol. 22, 152-159. doi:10.1038/sj.jim.2900622

Persson, F., Heinicke, G., Uhl, W., Hedberg, T., Hermansson, M., 2006. Performance of direct biofiltration of surface water for reduction of biodegradable organic matter and biofilm formation potential. Environ. Technol. 27, 1037-45. doi:10.1080/09593332708618717

Pharand, L., 2014. Carbon and Nitrogen Removal at a Full-Scale Municipal Drinking Water Treatment Plant employing Sand-ballasted Clarification, Ozone and Biofiltration (Master's Thesis). University of Waterloo. https://uwspace.uwaterloo.ca/handle/10012/8342.

Pharand, L., Dyke, M.I.V. a N., Anderson, W.B., Huck, P.M., 2014. Assessment of biomass in drinking water biofilters by adenosine triphosphate. Am. Water Work. Assoc. 433-444.

Qin, S., Ma, F., Huang, P., Yang, J., 2009. Fe (II) and Mn (II) removal from drilled well water: A case study from a biological treatment unit in Harbin. Desalination 245, 183-193. doi:10.1016/j.desal.2008.04.048

Richardson, S.D., 2003. Disinfection by-products and other emerging contaminants in drinking water. TrAC - Trends Anal. Chem. 22, 666-684. doi:10.1016/S0165-9936(03)01003-3

Sahabi, D.M., Takeda, M., Suzuki, I., Koizumi, J. ichi, 2009. Removal of Mn2+ from water by "aged" biofilter media: The role of catalytic oxides layers. J. Biosci. Bioeng. 107, 151-157. doi:10.1016/j.jbiosc.2008.10.013

Saltnes, T., Eikebrokk, B., Ødegaard, H., 2002. Contact filtration of humic waters: Performance of an expanded clay aggregate filter (Filtralite) compared to a dual anthracite/sand filter. 
Water Sci. Technol. Water Supply 2, 17-23.

Scott, D.J., 2008. Cryptosporidium and Particle Removal from Low Turbidity Water by Engineered Ceramic Media Filtration 1-278.

Seppanen, H., 1988. Biological treatment of groundwater in basins with foating filters - II The role of microorganisms. Wat. Sci. Tech. 20, 185-187.

Seredyńska-Sobecka, B., Tomaszewska, M., Janus, M., Morawski, A.W., 2006. Biological activation of carbon filters. Water Res. 40, 355-363. doi:10.1016/j.watres.2005.11.014

Servais, B.P., 1994. Biological Colonization of Granular Activated Carbon Fllters in DrinkingWater Treatment. J. Environ. Eng. 120, 888-899. doi:10.1061/(ASCE)07339372(1994)120:4(888)

Shraddha, Shekher, R., Sehgal, S., Kamthania, M., Kumar, A., 2011. Laccase: microbial sources, production, purification, and potential biotechnological applications. Enzyme Res. 2011, 217861. doi:10.4061/2011/217861

Singer, P.C., 1999. Humic Substances as Precursors for Potentially Harmful Disinfectant byproducts. Water Sci. Technol. Water Supply 40, 25-30.

Singer, P.C., 1994. Control of Disinfection By-Products in Drinking Water. Environ. Eng. Sci. $120,727-744$.

Smeds, A., Vartiainen, T., Mäki-Paakkanen, J., Kronberg, L., 1997. Concentrations of Ames mutagenic chlorohydroxyfuranones and related compounds in drinking waters. Environ. Sci. Technol. 31, 1033-1039. doi:10.1021/es960504q

Stoddart, A.K., Gagnon, G.A., 2015. Full-scale prechlorine removal: Impact on filter performance and water quality. Am. Water Work. Assoc. 107, E638-E647. doi:10.5942/jawwa.2015.107.0180

Target Products Limited, 2016. Anthracite Filter Media: Product Specifications. http://www.targetproducts.com/UserContent/SpecSheets/anthraci.pdf. 
Urfer, D., Huck, P.M., Booth, S.D.J., Coffey, B.M., 1997. Biological filtration for BOM and particle removal: a critical review. J. - AWWA 89, 83-98.

Valdes, J.R., Liang, S.-H., 2006. Stress-Controlled Filtration with Compressible Particles. J. Geotech. Geoenvironmental Eng. 132, 861-868. doi:10.1061/(ASCE)10900241(2006)132:7(861)

Velten, S., Boller, M., Köster, O., Helbing, J., Weilenmann, H.U., Hammes, F., 2011. Development of biomass in a drinking water granular active carbon (GAC) filter. Water Res. 45, 6347-6354. doi:10.1016/j.watres.2011.09.017

Velten, S., Hammes, F., Boller, M., Egli, T., 2007. Rapid and direct estimation of active biomass on granular activated carbon through adenosine tri-phosphate (ATP) determination. Water Res. 41, 1973-1983. doi:10.1016/j.watres.2007.01.021

Wang, J.Z., Summers, R.S., Miltner, R.J., 1995. Biofiltration performance: part 1, relationship to biomass. Am. Water Work. Assoc. 87, 55-63.

Wassink, J.K., Andrews, R.C., Peiris, R.H., Legge, R.L., 2011. Evaluation of fluorescence excitation-emission and LC-OCD as methods of detecting removal of NOM and DBP precursors by enhanced coagulation. Water Sci. Technol. Water Supply 11, 621-630. doi:10.2166/ws.2011.101

Wateropolis, 2014. Product specifications. http://wateropolis.com/pdf/Ceralite-A\%20Media.pdf.

Weinberg, H.S., Krasner, S.W., Richardson, S.D., Thruston, a D., 2002. The Occurrence of Disinfection By-Products (DBPs) of Health Concern in Drinking Water: Results of a Nationwide DBP Occurrence Study 462p. doi:EPA/600/R-02/068

Xiang, H., Lu, X., Yin, L., Yang, F., Zhu, G., Liu, W., 2013. Microbial community characterization, activity analysis and purifying efficiency in a biofilter process. J. Environ. Sci. (China) 25, 677-687. doi:10.1016/S1001-0742(12)60089-8

Yavich, A.A., Lee, K.H., Chen, K.C., Pape, L., Masten, S.J., 2004. Evaluation of biodegradability 
of NOM after ozonation. Water Res. 38, 2839-2846. doi:10.1016/j.watres.2004.03.040

Zhu, I.X., Getting, T., Bruce, D., 2010. Review of biologically active filters in drinking water applications. Am. Water Work. Assoc. 102, 67-77.

Zularisam, A.W., Ismail, A.F., Salim, M.R., Sakinah, M., Matsuura, T., 2009. Application of coagulation-ultrafiltration hybrid process for drinking water treatment: Optimization of operating conditions using experimental design. Sep. Purif. Technol. 65, 193-210. doi:10.1016/j.seppur.2008.10.018 


\section{Appendices}

\subsection{Standard Operating Procedure Outlines}

The following tables outlines the procedure that was used for sample preparation and analysis during the study. Information for the analysis of ATP (Table 8-1), DOC (Table 8-2), trihalomethanes (THMs) (Table 8-3), haloacetic acids (HAAs) (Table 8-4), enzyme assay (Table 8-5), and media fixation (Table 8-6).

Table 8-1: ATP Analysis Method

\section{Calibration}

1. Add $100 \mu \mathrm{L}$ of enzyme reagent (Luminase) and $100 \mu \mathrm{L}$ of ATP standard (Ultracheck 1) in a $12 \times 55 \mathrm{~mm}$ test tube

2. Measure the relative light units (RLU) using the luminometer (RLUstandard)

\section{Sample Analysis}

1. Weigh $1 \mathrm{~g}$ of sample and transfer to a $5 \mathrm{~mL}$ (pre-packaged) UltraLyse ${ }^{\mathrm{TM}} 7$ tube and mix

2. Wait for 5 minutes

3. Transfer $1 \mathrm{~mL}$ of the UltraLyse ${ }^{\mathrm{TM}} 7$ solution to a $9 \mathrm{~mL}$ (pre-packaged) UltraLute vial

4. After mixing the UltraLute solution, pipette $100 \mu \mathrm{L}$ to a new $12 \times 55 \mathrm{~mm}$ test tube.

5. Add $100 \mu \mathrm{L}$ of Luminase and gently swirl 5 times

6. Place the test tube into the luminometer and measure the RLU (RLU $U_{\text {sample}}$ )

7. Determine ATP concentration using the following equation:

$$
A T P\left(\frac{p g A T P}{g \text { media }}\right)=\frac{R L U_{\text {sample }}}{R L U_{\text {standard }}} \times \frac{50,000(p g A T P)}{\text { mass }_{\text {sample }}(g)}
$$


Table 8-2: Dissolved Organic Carbon (DOC) Method

\section{Blanks}

Use $40 \mathrm{~mL}$ of Milli-Q ${ }^{\circledR}$

\section{Stock Solution}

Mix $2.13 \mathrm{~g}$ potassium hydrogen phthalate in $1 \mathrm{~L}$ Milli- $\mathrm{Q}{ }^{\circledR}$ water. Store at $\mathrm{pH} \leq 2$ by acidifying with $\mathrm{H}_{2} \mathrm{SO}_{4}$.

\section{Calibration Solution $(10 \mathrm{mg} / \mathrm{L})$}

Add $1 \mathrm{~mL}$ of stock solution to $99 \mathrm{~mL}$ of Milli-Q® water.

\section{Check Standard $(2.5 \mathrm{mg} / \mathrm{L})$}

Add $250 \mu \mathrm{L}$ of stock solution to $99.75 \mathrm{~mL}$ Milli-Q® water.

\section{Samples}

Follow SOP for TOC analyzer.

Table 8-3: THM Extraction and Analysis Procedure

1. Collect samples in $20 \mathrm{~mL}$ amber vials and quench with $0.020 \mathrm{~g}$ of ascorbic acid

2. Store samples in the dark at $4^{0} \mathrm{C}$ for up to 7 days before analysis

3. Remove from refrigerator and bring to room temperature before preparation

4. Blank preparation: Transfer $20 \mathrm{~mL}$ of Milli-Q ${ }^{\circledR}$ water into $40 \mathrm{~mL}$ vial and prepare with samples.

5. Intermediate solution: Prepare $20 \mathrm{mg} / \mathrm{L}$ THM solution by adding $10 \mathrm{~mL}$ of stock solution $(2000 \mu \mathrm{g} / \mathrm{mL})$ to $990 \mathrm{~mL}$ of Milli-Q ${ }^{\circledR}$ water.

6. Calibration solutions: Prepare by adding the corresponding amount of intermediate solution to Milli-Q® water to achieve concentrations of 0, 5, 10, 20, 40, 60, 100, 150, and $200 \mu \mathrm{g} / \mathrm{L}$

**Wipe the syringe tip with a Kimwipe before measuring out of the THM stock or intermediate solutions, and before adding to intermediate and calibration solutions. 
Table 8-3: THM Extraction and Analysis Procedure (Cont.)

\section{Standard preparation}

1. Add $40 \mu \mathrm{L}$ of intermediate solution to $20 \mathrm{~mL}$ of Milli-Q® water in a $40 \mathrm{~mL}$ vial and process with other samples. Salt and MTBE should be added after adding intermediate solution.

2. Analyze a blank and running standard after every tenth sample.

\section{Extraction}

1. Transfer the contents of each sample vial into a clean $40 \mathrm{~mL}$ vial.

2. Add 2 scoops of sodium sulphate $\left(\mathrm{Na}_{2} \mathrm{SO}_{4}\right)$ to increase extraction efficiency. Add $4 \mathrm{~mL}$ of MTBE extraction solvent and cap with a Teflon®-lined silicon septum and cap.

3. Shake vial vigorously for 30 seconds and place vial on its side. Repeat for all samples, blanks and standards. Place samples upright in a rack and shake for 2 minutes. Let stand for 10 minutes.

4. Extract $2 \mathrm{~mL}$ from the organic layer using a Pasteur pipette and place in a $1.8 \mathrm{~mL} \mathrm{GC}$ vial filled with 2 small scoops of $\mathrm{Na}_{2} \mathrm{SO}_{4}$ (no water should remain in the vial). Use a clean pipette for each sample. Fill the vial to the top and cap immediately, ensuring there is no headspace. To ensure the MTBE phase was the only one taken, freeze the vials for 2 hours and observe that only 1 phase is visible.

5. If not analyzing immediately, freeze samples for up to 21 days.

6. Analyze using a GC-ECD

Table 8-4: HAA Extraction and Analysis Procedure

1. Collect samples in $40 \mathrm{~mL}$ amber vials. Ensure that samples are free of headspace.

2. Store samples in the dark at $4{ }^{0} \mathrm{C}$ for up to 9 days.

3. To begin sample preparation, remove from refrigerator and bring to room temperature

\section{Blanks}

1. Transfer $40 \mathrm{~mL}$ of Milli-Q ${ }^{\circledR}$ water into $40 \mathrm{~mL}$ vials and process with other samples. 
Table 8-4: HAA Extraction and Analysis Procedure (Cont.)

\section{Calibration Solutions}

1. Collect $20 \mathrm{~mL}$ of Milli-Q® in $40 \mathrm{~mL}$ vial

2. Using a $50 \mu \mathrm{L}$ syringe and the "sandwich" technique, add 0, 5, 10, 20, 40, 60, 100, and $150 \mu \mathrm{L}$ of HAA stock $(2000 \mu \mathrm{g} / \mathrm{mL}$ each $)$

**Wipe the syringe tip with a Kimwipe before measuring out of the HAA stock and before adding the stock to other solutions.

\section{Running Standards}

1. Add $50 \mu \mathrm{L}$ of working solution to $20 \mathrm{~mL}$ of Milli-Q ${ }^{\circledR}$ water, process alongside samples.

2. Include blanks and running standards after every tenth sample.

\section{Diazomethane Generation}

1. Set up MNNG diazomethane generation apparatus on ice using a beaker filled with crushed ice and water.

2. Add $2.5 \mathrm{~mL}$ of MTBE to outer tube of generator, and cover with tin foil before placing in ice bath.

3. Add $\sim 1.25 \mathrm{~cm}$ of diazald to inner tube of generator using large end of Pasteur pipette. Add $\sim 0.5 \mathrm{~mL}$ of methanol to cover diazald by $3 \mathrm{~mm}$ and secure cap and septum.

4. Place O-ring in glass joint. Position inside tube firmly on top and secure clamp. Ensure that the vapour exit hole is located on the opposite side of the tube from the clamp and place clamp on the spout of the beaker. Ensure the seal is tight to maximize CH2N2 generation and recovery.

5. Let cool on the ice bath for $10 \mathrm{~min}$.

6. Add $600 \mu \mathrm{L}$ of $20 \% \mathrm{NaOH}$ solution dropwise to inner tube with a gas tight syringe (1 drop/5 sec). Aim drops directly into the diazald in the bottom of the inner tube. Leave the syringe in place after all of the $\mathrm{NaOH}$ is added to avoid a hole in the septum from which $\mathrm{CH}_{2} \mathrm{~N}_{2}$ may exit. Allow $\mathrm{CH}_{2} \mathrm{~N}_{2}$ to form for 30 to 45 minutes on the ice bath. 
Table 8-4: HAA Extraction and Analysis Procedure (Cont.)

\section{Extraction}

1. Transfer $20 \mathrm{~mL}$ of sample into a clean $40 \mathrm{~mL}$ vial.

2. Add $3 \mathrm{~mL}$ of sulphuric acid $\left(\mathrm{H}_{2} \mathrm{SO}_{4}\right)$. Add $6 \mathrm{~g}$ of sodium sulphate $\left(\mathrm{Na}_{2} \mathrm{SO}_{4}\right)$. Add $5 \mathrm{~mL}$ of MTBE extraction solvent and cap with a Teflon®-lined silicon septa and screw cap.

3. Shake sample for $\sim 30$ seconds and place vial on its side. Repeat for all blanks, calibration solutions and samples.

4. Place samples upright in a rack and shake for 5 minutes. Let samples stand for 15 minutes.

5. Extract $1.5 \mathrm{~mL}$ from the organic layer and place into a $1.8 \mathrm{~mL}$ GC vial using a clean pipette for each sample. Add $150 \mu \mathrm{L}$ of diazomethane to the $\mathrm{GC}$ vial (submerging the syringe tip before injection) and seal immediately.

6. If not analyzing immediately, store the samples in a freezer $\left(-20^{\circ} \mathrm{C}\right)$ for up to 21 days.

7. Analyze using a GC-ECD.

Table 8-5: Enzyme Extraction \& Laccase and Esterase Activity Assay

\section{Enzyme Extraction}

1. Fill a $40 \mathrm{~mL}$ amber vial with $15 \mathrm{~mL}$ of Tris buffer.

2. Measure out $1 \mathrm{~g}$ of media, and place in vial with Tris buffer.

3. Repeat for all samples.

4. Sonicate samples for 15 minutes.

\section{Laccase Activity}

1. Prepare approximately $10 \mathrm{~mL}$ of L-DOPA with a concentration of $20 \mathrm{Mm}$.

2. Using a 96-well plate, inject $200 \mu \mathrm{L}$ of media extract. Complete in duplicate or triplicate as necessary.

3. Fill other wells with a series of blanks: tris, laccase solution, media extract.

4. Using the plate reader, collect 1 reading of each sample prior to laccase addition at an absorbance of $460 \mathrm{~nm}$. 
Table 8-5: Enzyme Extraction \& Laccase and Esterase Activity Assay (Cont.)

5. Add $25 \mu \mathrm{L}$ of laccase solution to all samples, excluding blanks.

6. Place back into the plate reader.

7. Collect reading of absorbance at $460 \mathrm{~nm}$ every 15 minutes for a minimum of 36 hours (preferably 72 hours if the enzyme activity is expected to be low.

\section{Esterase Activity}

1. Prepare $10 \mathrm{~mL}$ of $10 \mathrm{mM}$ stock solutions of $4 \mathrm{MUB}(17.6 \mathrm{mg}) \mathrm{B}$ and $4 \mathrm{MUB}$-acetate $(21.8 \mathrm{mg})$ in DMSO.

2. Dilute each compound to a concentration of $200 \mu \mathrm{M}$ by adding $0.5 \mathrm{~mL}$ of concentrate to $24.5 \mathrm{~mL}$ of buffer.

3. Prepare a calibration curve ranging from 0 to $100 \mu \mathrm{M}$ using the $200 \mu \mathrm{M}$ solution just made. Use the $2.5 \mathrm{~mL}$ fluorescence vial and prepare all calibration solutions in these.

4. Setup the fluorescence spectrometer using simple reads with an excitation wavelength of $370 \mathrm{~nm}$ and an emission wavelength of $445 \mathrm{~nm}$

5. Zero the fluorescence spectrometer with Milli-Q water.

6. Adjust the excitation energy such the $100 \mu \mathrm{m}$ calibration standard does not put the machine over range.

7. Collect the emission value for each of the standards.

8. On the spectrophotometer, measure the absorbance at $370 \mathrm{~nm}$ and $445 \mathrm{~nm}$ for each of the standards. These values will be used for absorbance correction.

9. In a $2.5 \mathrm{~mL}$ add $1.6 \mathrm{~mL}$ of media extract for each of your samples. Complete in duplicate or triplicate as required.

10. Add $0.4 \mathrm{~mL}$ of $4 \mathrm{MUB}$ acetate $(200 \mu \mathrm{M})$.

11. Measure the fluorescence of each sample, using the conditions provided above, as rapidly as possible (every 10-15 minutes is preferable)

12. Measure the absorbance of each sample immediately after measuring the fluorescence so that the results can be corrected.

13. Repeat steps 11 and 12 until a consistent value is achieved, indicating all of the substrate has been consumed. 
Table 8-6: Biological Media Fixation

\section{Media Fixation}

1. Store media samples in clean $40 \mathrm{~mL}$ vial and rinse with deionized water (DI) multiples times to remove extra debris.

2. Fix samples with $5 \%$ Glutaraldehyde in $0.1 \mathrm{M}$ phosphate buffer at $4^{\circ} \mathrm{C}$ for $6-24$ hours.

3. Wash samples thrice with tris buffer followed by DI water for 10-15 minutes.

4. Air dry samples using a dilution series of ethanol $(50,75,100$, and 100) for 30 minutes each.

5. Decant the ethanol; leave the sample vial in desiccator overnight at room temperature.

6. Mount the dry samples on SEM stub with double-sided sticky tape and sputter coat with gold. Image the samples under SEM. 


\subsection{Raw Data}

Analytical results for the Lake Ontario pilot plant are presented in Table 8-7. The analytical parameters include ATP, pH, DOC, UV 254, turbidity, THMs, and HAAs. Results from the Lake Erie pilot plant are presented in Table 8-8 and include ATP, pH, DOC, $\mathrm{UV}_{254}$, turbidity, Cl-residuals, manganese, iron, THMs, and HAAs.

Table 8-7: Raw Data: Lake Ontario Pilot Plant

\begin{tabular}{|c|c|c|c|c|c|c|c|}
\hline Analyte & Date & Raw & Post-03 & BAC & BAF & CER 1.2 & CER 1.0 \\
\hline \multirow{22}{*}{$\mathrm{pH}$} & $07-$ Oct-15 & 7.86 & 7.62 & 7.61 & 7.51 & 7.62 & 7.66 \\
\hline & 14-Oct-15 & 7.53 & 7.71 & 7.59 & 7.71 & 7.63 & 7.6 \\
\hline & 21-Oct-15 & 7.59 & 7.43 & 7.43 & 7.37 & 7.45 & 7.41 \\
\hline & 27-Oct-15 & 7.47 & 7.49 & 7.56 & 7.47 & 7.68 & 7.43 \\
\hline & 03-Nov-15 & 7.41 & 7.56 & 7.61 & 7.58 & 7.58 & 7.49 \\
\hline & 11-Nov-15 & 7.37 & 7.44 & 7.39 & 7.37 & 7.36 & 7.41 \\
\hline & 18-Nov-15 & 7.4 & 7.5 & 7.35 & 7.35 & 7.31 & 7.35 \\
\hline & 27-Nov-15 & 7.52 & 7.47 & 7.54 & 7.41 & 7.47 & 7.42 \\
\hline & 08-Dec-15 & 7.57 & 7.49 & 7.55 & 7.42 & 7.66 & 7.44 \\
\hline & 15-Dec-15 & 7.61 & 7.43 & 7.59 & 7.48 & 7.57 & 7.56 \\
\hline & 18-Jan-16 & 7.79 & 7.65 & 7.68 & 7.49 & 7.82 & 7.69 \\
\hline & 09-Feb-16 & 7.81 & 7.84 & 7.69 & 7.68 & 7.76 & 7.81 \\
\hline & 23-Feb-16 & 7.87 & 7.78 & 7.65 & 7.56 & 7.79 & 7.67 \\
\hline & 08-Mar-16 & 7.94 & 7.84 & 7.83 & 7.84 & 7.81 & 7.85 \\
\hline & 22-Mar-16 & 7.91 & 7.93 & 7.76 & 7.67 & 7.83 & 7.76 \\
\hline & 12-Apr-16 & 7.57 & 7.49 & 7.55 & 7.42 & 7.66 & 7.44 \\
\hline & 20-Apr-16 & 7.61 & 7.43 & 7.59 & 7.48 & 7.57 & 7.56 \\
\hline & 11-Маy-16 & 8.06 & 7.99 & 7.80 & 7.88 & 7.94 & 8.00 \\
\hline & 17-Маy-16 & 7.88 & 7.95 & 7.69 & 7.77 & 7.8 & 7.82 \\
\hline & 01-Jun-16 & 7.95 & 7.89 & 7.71 & 7.98 & 7.97 & 7.9 \\
\hline & 13-Jun-16 & 8.07 & 8.02 & 7.81 & 8.02 & 8.04 & 8.04 \\
\hline & 28-Jun-16 & 8.19 & 8.07 & 6.94 & 8.00 & 7.96 & 7.97 \\
\hline
\end{tabular}


Table 8-7: Raw Data - Lake Ontario Pilot Plant (Cont.)

\begin{tabular}{|c|c|c|c|c|c|c|c|}
\hline Analyte & Date & Raw & Post-O3 & BAC & BAF & CER 1.2 & CER 1.0 \\
\hline \multirow{6}{*}{$\mathrm{pH}$} & 11-Jul-16 & 7.92 & 7.88 & 7.66 & 7.76 & 7.81 & 7.82 \\
\hline & 25-Jul-16 & 7.96 & 7.92 & 7.58 & 7.68 & 7.84 & 7.78 \\
\hline & 10-Aug-16 & 7.91 & 7.87 & 7. 66 & 7.73 & 7.72 & 7.69 \\
\hline & 24-Aug-16 & 7.79 & 7.71 & 7.53 & 7.78 & 7.66 & 7.66 \\
\hline & 07-Sep-16 & 7.87 & 7.83 & 7.72 & 7.76 & 7.81 & 7.74 \\
\hline & 21-Sep-16 & 7.88 & 7.79 & 7.71 & 7.68 & 7.72 & 7.79 \\
\hline \multirow{20}{*}{$\begin{array}{c}\text { DOC } \\
(\mathrm{mg} / \mathrm{L})\end{array}$} & 07-Oct-15 & NA & 2.2 & 1.8 & 2.3 & 2.4 & 2.5 \\
\hline & $14-O c t-15$ & 2.3 & 2.3 & 1.6 & 2.2 & 2.3 & 2.2 \\
\hline & 21-Oct-15 & 2.1 & 2.3 & 1.6 & 2.2 & 2.2 & 2.1 \\
\hline & $27-O c t-15$ & 1.9 & 1.9 & 1.5 & 2.0 & 1.9 & 1.9 \\
\hline & 03-Nov-15 & 2.3 & 2.2 & 1.8 & 2.1 & 2.1 & 2.2 \\
\hline & 11-Nov-15 & 2.2 & 2.2 & 1.8 & 2.1 & 2.1 & 2.1 \\
\hline & 18-Nov-15 & 2.0 & 2.3 & 1.7 & 2.2 & 2.0 & 2.0 \\
\hline & 27-Nov-15 & 2.0 & 2.4 & 1.2 & 1.3 & 1.2 & 2.2 \\
\hline & 08-Dec-15 & 2.4 & 2.0 & 1.7 & 2.1 & 1.9 & 1.9 \\
\hline & 15-Dec-15 & 2.0 & 1.8 & 1.5 & 1.7 & 1.7 & 1.7 \\
\hline & 18-Jan-16 & 2.1 & 2.0 & 1.8 & 2.1 & 2.0 & 2.0 \\
\hline & 09-Feb-16 & 2.2 & 2.1 & 1.9 & 2.0 & 2.0 & 2.0 \\
\hline & 23-Feb-16 & 2.1 & 2.2 & 1.9 & 2.1 & 2.0 & 2.2 \\
\hline & 08-Mar-16 & 2.1 & 2.1 & 1.8 & 2.0 & 2.0 & 2.0 \\
\hline & 22-Mar-16 & 2.0 & 2.0 & 2.0 & 2.1 & 2.0 & 2.0 \\
\hline & 12-Apr-16 & 2.4 & 2.4 & 2.1 & 2.2 & 2.3 & 2.5 \\
\hline & 20-Apr-16 & 2.0 & 2.0 & 1.9 & 2.1 & 2.0 & 2.0 \\
\hline & 11-Мay-16 & 2.4 & 2.3 & 2.2 & 2.3 & 2.2 & 2.2 \\
\hline & 17-Мау-16 & 2.2 & 2.1 & 2.0 & 2.1 & 2.2 & 2.2 \\
\hline & 01-Jun-16 & 2.1 & 2.2 & 2.0 & 2.1 & 2.2 & 2.1 \\
\hline
\end{tabular}

NA: Not Available 
Table 8-7: Raw Data - Lake Ontario Pilot Plant (Cont.)

\begin{tabular}{|c|c|c|c|c|c|c|c|}
\hline Analyte & Date & Raw & Post-O3 & BAC & BAF & CER 1.2 & CER 1.0 \\
\hline \multirow{8}{*}{$\begin{array}{c}\text { DOC } \\
(\mathrm{mg} / \mathrm{L})\end{array}$} & 13-Jun-16 & 2.0 & 1.9 & 1.8 & 1.9 & 1.9 & 1.9 \\
\hline & 28-Jun-16 & 2.2 & 2.1 & 2.0 & 2.0 & 2.0 & 2.1 \\
\hline & 11-Jul-16 & 2.4 & 2.3 & 2.1 & 2.2 & 2.2 & 2.3 \\
\hline & 25-Jul-16 & 2.5 & 2.5 & 2.1 & 2.3 & 2.3 & 2.3 \\
\hline & 10-Aug-16 & 2.2 & 2.2 & 1.9 & 2.2 & 2.1 & 2.1 \\
\hline & 24-Aug-16 & 2.4 & 2.5 & 2.1 & 2.4 & 2.3 & 2.3 \\
\hline & 07-Sep-16 & 2.5 & 2.4 & 2.1 & 2.4 & 2.4 & 2.3 \\
\hline & 21-Sep-16 & 2.4 & 2.4 & 2.1 & 2.2 & 2.4 & 2.3 \\
\hline \multirow{19}{*}{$\begin{array}{l}\mathrm{UV}_{254} \\
\left(\mathrm{~cm}^{-1}\right)\end{array}$} & 07-Oct-15 & 0.018 & 0.015 & 0.006 & 0.013 & 0.014 & 0.013 \\
\hline & $14-O c t-15$ & 0.019 & 0.012 & 0.010 & 0.013 & 0.012 & 0.013 \\
\hline & 21-Oct-15 & 0.015 & 0.010 & 0.008 & 0.011 & 0.011 & 0.009 \\
\hline & 27-Oct-15 & 0.017 & 0.012 & 0.010 & 0.012 & 0.015 & 0.012 \\
\hline & 03-Nov-15 & 0.016 & 0.012 & 0.010 & 0.012 & 0.012 & 0.012 \\
\hline & 11-Nov-15 & 0.019 & 0.018 & 0.013 & 0.014 & 0.016 & 0.018 \\
\hline & 18-Nov-15 & 0.018 & 0.015 & 0.015 & 0.017 & 0.015 & 0.015 \\
\hline & 08-Dec-15 & 0.018 & 0.016 & 0.011 & 0.014 & 0.012 & 0.011 \\
\hline & 15-Dec-15 & 0.019 & 0.018 & 0.013 & 0.016 & 0.017 & 0.017 \\
\hline & 18-Jan-16 & 0.016 & 0.015 & 0.012 & 0.015 & 0.014 & 0.014 \\
\hline & 09-Feb-16 & 0.018 & 0.017 & 0.014 & 0.017 & 0.016 & 0.015 \\
\hline & 23-Feb-16 & 0.019 & 0.016 & 0.012 & 0.015 & 0.015 & 0.016 \\
\hline & 08-Mar-16 & 0.020 & 0.016 & 0.011 & 0.016 & 0.015 & 0.016 \\
\hline & 22-Mar-16 & 0.021 & 0.017 & 0.012 & 0.018 & 0.018 & 0.019 \\
\hline & 12-Apr-16 & 0.018 & 0.016 & 0.011 & 0.015 & 0.015 & 0.014 \\
\hline & $20-A p r-16$ & 0.019 & 0.017 & 0.014 & 0.017 & 0.017 & 0.016 \\
\hline & 11-May-16 & 0.015 & 0.014 & 0.011 & 0.012 & 0.012 & 0.011 \\
\hline & 17-May-16 & 0.017 & 0.015 & 0.012 & 0.015 & 0.015 & 0.016 \\
\hline & 01-Jun-16 & 0.018 & 0.016 & 0.013 & 0.014 & 0.017 & 0.016 \\
\hline
\end{tabular}


Table 8-7: Raw Data - Lake Ontario Pilot Plant (Cont.)

\begin{tabular}{|c|c|c|c|c|c|c|c|}
\hline Analyte & Date & Raw & Post-O3 & BAC & BAF & CER 1.2 & CER 1.0 \\
\hline \multirow{8}{*}{$\begin{array}{l}\mathrm{UV}_{254} \\
\left(\mathrm{~cm}^{-1}\right)\end{array}$} & 13-Jun-16 & 0.017 & 0.015 & 0.014 & 0.014 & 0.016 & 0.015 \\
\hline & 28-Jun-16 & 0.020 & 0.015 & 0.014 & 0.015 & 0.015 & 0.015 \\
\hline & 11-Jul-16 & 0.022 & 0.018 & 0.015 & 0.018 & 0.018 & 0.018 \\
\hline & 25-Jul-16 & 0.022 & 0.016 & 0.014 & 0.015 & 0.015 & 0.017 \\
\hline & 10-Aug-16 & 0.022 & 0.016 & 0.013 & 0.016 & 0.015 & 0.016 \\
\hline & 24-Aug-16 & 0.023 & 0.015 & 0.014 & 0.017 & 0.017 & 0.017 \\
\hline & 07-Sep-16 & 0.023 & 0.016 & 0.012 & 0.016 & 0.021 & 0.013 \\
\hline & 21-Sep-16 & 0.023 & 0.020 & 0.014 & 0.017 & 0.016 & 0.017 \\
\hline \multirow{19}{*}{$\begin{array}{c}\text { Turbidity } \\
\text { (NTU) }\end{array}$} & $07-O c t-15$ & 2.67 & 2.01 & 0.34 & 0.387 & 0.319 & 0.203 \\
\hline & $14-O c t-15$ & 0.745 & 0.194 & 0.206 & 0.254 & 0.180 & 0.219 \\
\hline & 21-Oct-15 & 0.918 & 0.194 & 0.117 & 0.115 & 0.144 & 0.132 \\
\hline & 27-Oct-15 & 0.485 & 0.286 & 0.167 & 0.175 & 0.181 & 0.165 \\
\hline & 03-Nov-15 & 0.411 & 0.247 & 0.182 & 0.181 & 0.174 & 0.196 \\
\hline & 11-Nov-15 & 0.248 & 0.202 & 0.162 & 0.185 & 0.080 & 0.190 \\
\hline & 18-Nov-15 & 0.991 & 0.942 & 0.186 & 0.223 & 0.239 & 0.189 \\
\hline & 27-Nov-15 & 0.308 & 0.238 & 0.156 & 0.157 & 0.110 & 0.123 \\
\hline & 08-Dec-15 & 0.300 & 0.217 & 0.164 & 0.160 & 0.130 & 0.137 \\
\hline & 15-Dec-15 & 0.413 & 0.269 & 0.171 & 0.168 & 0.149 & 0.155 \\
\hline & 18-Jan-16 & 0.302 & 1.11 & 0.169 & 0.168 & 0.198 & 0.193 \\
\hline & 09-Feb-16 & 0.636 & 0.567 & 0.399 & 0.395 & 0.587 & 0.426 \\
\hline & 23-Feb-16 & 0.606 & 0.534 & 0.219 & 0.163 & 0.251 & 0.252 \\
\hline & 08-Mar-16 & 0.456 & 0.495 & 0.154 & 0.177 & 0.221 & 0.152 \\
\hline & 22-Mar-16 & 0.378 & 2.09 & 0.167 & 0.198 & 0.176 & 0.207 \\
\hline & 12-Apr-16 & 0.495 & 0.654 & 0.197 & 0.19 & 0.178 & 0.167 \\
\hline & 20-Apr-16 & 0.474 & 0.567 & 0.186 & 0.175 & 0.198 & 0.179 \\
\hline & 11-May-16 & 0.507 & 0.585 & 0.255 & 0.22 & 0.19 & 0.186 \\
\hline & 17-Мау-16 & 0.19 & 0.239 & 0.08 & 0.089 & 0.097 & 0.091 \\
\hline
\end{tabular}


Table 8-7: Raw Data - Lake Ontario Pilot Plant (Cont.)

\begin{tabular}{|c|c|c|c|c|c|c|c|}
\hline Analyte & Date & Raw & Post-O3 & BAC & BAF & CER 1.2 & CER 1.0 \\
\hline \multirow{9}{*}{$\begin{array}{c}\text { Turbidity } \\
\text { (NTU) }\end{array}$} & 01-Jun-16 & 0.93 & 0.605 & 0.25 & 0.188 & 0.248 & 0.225 \\
\hline & 13-Jun-16 & 0.213 & 0.143 & 0.101 & 0.116 & 0.118 & 0.121 \\
\hline & 28-Jun-16 & 0.438 & 0.258 & 0.186 & 0.183 & 0.168 & 0.16 \\
\hline & 11-Jul-16 & 0.358 & 0.211 & 0.135 & 0.151 & 0.169 & 0.157 \\
\hline & 25-Jul-16 & 0.326 & 0.257 & 0.205 & 0.197 & 0.175 & 0.22 \\
\hline & 10 -Aug-16 & 0.323 & 0.26 & 0.124 & 0.154 & 0.155 & 0.137 \\
\hline & 24-Aug-16 & 0.256 & 0.325 & 0.203 & 0.151 & 0.192 & 0.196 \\
\hline & 07-Sep-16 & 0.477 & 0.401 & 0.196 & 0.189 & 0.185 & 0.178 \\
\hline & 21-Sep-16 & 0.346 & 0.334 & 0.182 & 0.191 & 0.201 & 0.169 \\
\hline \multirow{17}{*}{$\begin{array}{c}\text { ATP } \\
(\mathrm{pg} / \mathrm{g} \\
\text { media) }\end{array}$} & 23-Oct-15 & N/A & N/A & 143249 & 32674 & 28176 & 25327 \\
\hline & 23-Oct-15 & N/A & N/A & 149551 & 34826 & 27804 & 24453 \\
\hline & 08-Dec-15 & N/A & N/A & 505678 & 101445 & 92948 & 37846 \\
\hline & 08-Dec-15 & N/A & N/A & 513153 & 101227 & 94276 & 39140 \\
\hline & 18-Jan-16 & N/A & N/A & 207233 & 51225 & 36857 & 60361 \\
\hline & 18-Jan-16 & N/A & N/A & 247666 & 50320 & 44796 & 67320 \\
\hline & 09-Feb-16 & N/A & N/A & 230955 & 82303 & 25654 & 52089 \\
\hline & 09-Feb-16 & N/A & N/A & 233025 & 81681 & 25833 & 49140 \\
\hline & 23-Feb-16 & N/A & N/A & 293070 & 129171 & 69309 & 20148 \\
\hline & 23-Feb-16 & N/A & N/A & 312224 & 128067 & 70837 & 21917 \\
\hline & 08-Mar-16 & N/A & N/A & 270141 & 108619 & 40849 & 69957 \\
\hline & 08-Mar-16 & N/A & N/A & 223171 & 98071 & 39619 & 62897 \\
\hline & 12-Apr-16 & N/A & N/A & 275107 & 114509 & 54167 & 43264 \\
\hline & 12-Apr-16 & N/A & N/A & 274197 & 117455 & 56139 & 44196 \\
\hline & 17-May-16 & N/A & N/A & 263885 & 109982 & 133120 & 146753 \\
\hline & 17-May-16 & N/A & N/A & 262187 & 114511 & 138519 & 147607 \\
\hline & 13-Jun-16 & N/A & N/A & 629097 & 161698 & 196340 & 205487 \\
\hline
\end{tabular}

N/A : Not Applicable 
Table 8-7: Raw Data - Lake Ontario Pilot Plant (Cont.)

\begin{tabular}{|c|c|c|c|c|c|c|c|}
\hline Analyte & Date & Raw & Post-O3 & BAC & BAF & CER 1.2 & CER 1.0 \\
\hline \multirow{9}{*}{$\begin{array}{c}\text { ATP } \\
(\mathrm{pg} / \mathrm{g} \\
\text { media) }\end{array}$} & 13-Jun-16 & N/A & N/A & 650435 & 164393 & 214273 & 224141 \\
\hline & 13-Jul-16 & N/A & N/A & 120337 & 73114 & 134888 & 239564 \\
\hline & 13-Jul-16 & N/A & N/A & 128650 & 87698 & 153556 & 226330 \\
\hline & 10-Aug-16 & N/A & N/A & 137882 & 32393 & 145403 & 111330 \\
\hline & 10-Aug-16 & N/A & N/A & 133103 & 36226 & 145851 & 112635 \\
\hline & 07-Sep-16 & N/A & N/A & 363030 & 144066 & 326925 & 711745 \\
\hline & 07-Sep-16 & N/A & N/A & 365811 & 144783 & 353279 & 118738 \\
\hline & 01-Nov-16 & N/A & N/A & 20774 & 328354 & 79120 & 46608 \\
\hline & 01-Nov-16 & N/A & N/A & 18978 & 321176 & 81126 & 48530 \\
\hline \multirow{16}{*}{$\begin{array}{l}\text { Total } \\
\text { THMs } \\
(\mu \mathrm{g} / \mathrm{L})\end{array}$} & 08-Dec-15 & 33.5 & 32.5 & 22.9 & 31.5 & 31.1 & 28.8 \\
\hline & 08-Dec-15 & 32.3 & 33.0 & 22.8 & 30.7 & 33.1 & 30.0 \\
\hline & 09-Feb-16 & 27.1 & 25.3 & 20.6 & 26.7 & 23.6 & 23.5 \\
\hline & 09-Feb-16 & 29.3 & 25.7 & 20.5 & 24.6 & 24.0 & 24.7 \\
\hline & 22-Mar-16 & 31.1 & 35.4 & 28.6 & 29.8 & 27.4 & 27.2 \\
\hline & 22-Mar-16 & 32.1 & 28.0 & 27.6 & 27.4 & 26.1 & 28.2 \\
\hline & 20-Apr-16 & 28.7 & 29.3 & 24.0 & 31.6 & 26.1 & 27.3 \\
\hline & 20-Apr-16 & 29.4 & 28.1 & 23.7 & 27.5 & 26.8 & 26.2 \\
\hline & 17-May-16 & 31.9 & 30.0 & 22.8 & 28.4 & 27.4 & 27.0 \\
\hline & 17-Мay-16 & 31.3 & 30.2 & 24.3 & 29.9 & 27.5 & 30.1 \\
\hline & 28-Jun-16 & 34.0 & 35.5 & 25.1 & 27.5 & 27.4 & 28.2 \\
\hline & 28-Jun-16 & 32.0 & 33.4 & 22.8 & 28.7 & 26.7 & 27.7 \\
\hline & 13-Jul-16 & 31.0 & 31.2 & 20.2 & 25.0 & 23.1 & 29.0 \\
\hline & 13-Jul-16 & 30.8 & 30.8 & 19.1 & 25.3 & 25.7 & 27.0 \\
\hline & 10-Aug-16 & 35.9 & 34.3 & 22.5 & 28.5 & 29.3 & 29.9 \\
\hline & 10-Aug-16 & 34.3 & 33.9 & 19.9 & 29.2 & 29.6 & 30.1 \\
\hline
\end{tabular}

N/A : Not Applicable 
Table 8-7: Raw Data - Lake Ontario Pilot Plant (Cont.)

\begin{tabular}{|c|c|c|c|c|c|c|c|}
\hline Analyte & Date & Raw & Post-O3 & BAC & BAF & CER 1.2 & CER 1.0 \\
\hline \multirow{13}{*}{$\begin{array}{l}\text { Total } \\
\text { HAAs } \\
(\mu \mathrm{g} / \mathrm{L})\end{array}$} & 09-Feb-16 & 18.2 & 18.6 & 18.6 & 18.2 & 18.6 & 16.4 \\
\hline & 09-Feb-16 & 22.2 & 18.6 & 15.8 & 18.8 & 17.6 & 18.4 \\
\hline & 22-Mar-16 & 16.8 & 15.8 & 13.0 & 13.8 & 13.4 & 14.0 \\
\hline & 22-Mar-16 & 18.0 & 15.3 & NA & NA & 13.2 & 16.0 \\
\hline & 20-Apr-16 & 5.1 & 5.6 & 4.5 & 5.2 & 5.1 & 5.2 \\
\hline & 17-Мay-16 & 25.5 & 24.3 & NA & 22.5 & 22.6 & 21.5 \\
\hline & 17-Мay-16 & 21.2 & 23.3 & 17.3 & 22.2 & NA & 22.7 \\
\hline & 28-Jun-16 & 16.5 & 13.3 & 9.5 & 11.1 & 12.9 & 12.5 \\
\hline & 28-Jun-16 & 15.3 & 13.5 & 9.4 & 12.3 & 13.3 & 13.5 \\
\hline & 13-Jul-16 & 16.1 & 11.1 & 7.7 & 13.0 & 9.6 & 13.3 \\
\hline & 13-Jul-16 & 15.7 & 12.7 & 7.6 & 8.0 & 9.6 & 8.3 \\
\hline & 10-Aug-16 & 23.0 & 18.8 & 11.7 & 16.8 & 17.1 & 17.4 \\
\hline & 10-Aug-16 & 28.4 & 20.1 & 14.1 & 17.1 & 16.2 & 16.3 \\
\hline
\end{tabular}

NA : Not Available 
Table 8-8: Raw Data: Lake Erie Pilot Plant

\begin{tabular}{|c|c|c|c|c|c|c|c|}
\hline Analyte & Date & Settled/Cl & CAF1 & CAF2 & BAF1 & BAF2 & Raw \\
\hline & 08-Jan-16 & 7.04 & 7.32 & 7.29 & 7.20 & 7.16 & NS \\
\hline & 12-Jan-16 & 7.03 & 7.16 & 7.12 & 7.07 & 7.01 & NS \\
\hline & 15-Jan-16 & 6.92 & 7.13 & 7.13 & 7.15 & 7.06 & NS \\
\hline & 20-Jan-16 & 7.17 & 7.17 & 7.11 & 7.17 & 7.17 & NS \\
\hline & 25-Jan-16 & 7.04 & 7.2 & 7.25 & 7.28 & 7.19 & NS \\
\hline & 29-Jan-16 & NA & 7.09 & 7.12 & 7.12 & 7.12 & NS \\
\hline & 02-Feb-16 & 6.68 & 6.93 & 6.98 & 6.95 & 6.92 & NS \\
\hline & 05-Feb-16 & 7.10 & 7.28 & 7.24 & 7.24 & 7.28 & NS \\
\hline & 08-Feb-16 & 7.16 & 7.26 & 7.35 & 7.32 & 7.28 & NS \\
\hline & 12-Feb-16 & 7.09 & 7.26 & 7.26 & 7.26 & 7.30 & NS \\
\hline & 16-Feb-16 & 7.09 & 7.3 & 7.25 & 7.25 & 7.23 & NS \\
\hline & 18-Feb-16 & 7.00 & 7.19 & 7.18 & 7.15 & 7.14 & NS \\
\hline \multirow[t]{14}{*}{$\mathrm{pH}$} & 23-Feb-16 & 7.18 & 7.32 & 7.32 & 7.31 & 7.25 & NS \\
\hline & 26-Feb-16 & 6.96 & 7.13 & 7.14 & 7.18 & 7.15 & NS \\
\hline & 03-Mar-16 & 6.95 & 7.16 & 7.10 & 7.09 & 7.05 & NS \\
\hline & 08-Mar-16 & 7.02 & 7.2 & 7.18 & 7.23 & 7.25 & NS \\
\hline & 11-Mar-16 & 7.03 & 7.18 & 7.15 & 7.15 & 7.14 & NS \\
\hline & 15-Mar-16 & 6.99 & 7.13 & 7.19 & 7.14 & 7.09 & NS \\
\hline & 18-Mar-16 & 6.89 & 7.09 & 7.18 & 7.13 & 7.08 & NS \\
\hline & 22-Mar-16 & 6.96 & 7.14 & 7.11 & 7.16 & 7.08 & NS \\
\hline & 24-Mar-16 & 6.98 & 7.22 & 7.23 & 7.22 & 7.19 & NS \\
\hline & 29-Mar-16 & 7.1 & 7.27 & 7.3 & 7.22 & 7.24 & NS \\
\hline & 01-Apr-16 & 6.92 & 7.13 & 7.16 & 7.14 & 7.14 & NS \\
\hline & 06-Apr-16 & 7.03 & 7.23 & 7.19 & 7.21 & 7.20 & NS \\
\hline & 15-Apr-16 & 7.03 & 7.09 & 7.10 & 7.16 & 7.12 & NS \\
\hline & 20-Apr-16 & 7.11 & 7.13 & 7.14 & 7.23 & 7.25 & NS \\
\hline
\end{tabular}

NA : Not Available; NS: Not Sampled 
Table 8-8: Raw Data - Lake Erie Pilot Plant (Cont.)

\begin{tabular}{|c|c|c|c|c|c|c|c|}
\hline Analyte & Date & Settled/Cl & CAF1 & CAF2 & BAF1 & BAF2 & Raw \\
\hline \multirow{26}{*}{$\mathrm{pH}$} & 25-Apr-16 & 7.04 & 7.29 & 7.27 & 7.25 & 7.22 & NS \\
\hline & 29-Apr-16 & 7.00 & 7.23 & 7.25 & 7.23 & 7.19 & NS \\
\hline & 05-May-16 & 7.02 & 7.09 & 7.16 & 7.22 & 7.21 & NS \\
\hline & 09-Мay-16 & 7.07 & 7.15 & 7.11 & 7.16 & 7.17 & NS \\
\hline & 12-May-16 & 7.07 & 7.15 & 7.12 & 7.05 & 6.97 & NS \\
\hline & 17-May-16 & 6.98 & 7.18 & 7.18 & 7.11 & 7.05 & NS \\
\hline & 19-May-16 & 7.03 & 7.2 & 7.21 & 7.13 & 7.04 & NS \\
\hline & 24-Мay-16 & 7.34 & 6.99 & 7.04 & 7.13 & 7.20 & NS \\
\hline & 26-Мay-16 & 6.97 & 6.94 & 6.97 & 7.08 & 7.10 & NS \\
\hline & 31-Мay-16 & 7.05 & 7.09 & 7.00 & 7.10 & 7.18 & NS \\
\hline & 02-Jun-16 & 7.05 & 7.12 & 7.11 & 7.03 & 6.95 & NS \\
\hline & 07-Jun-16 & 7.04 & 7.18 & 7.15 & 7.04 & 6.92 & NS \\
\hline & 10-Jun-16 & 7.02 & 7.16 & 7.13 & 7.07 & 6.98 & NS \\
\hline & 14-Jun-16 & 6.95 & 6.89 & 6.94 & 7.09 & 7.09 & NS \\
\hline & 16-Jun-16 & 6.71 & 7.43 & 7.44 & 7.46 & 7.47 & NS \\
\hline & 20-Jun-16 & 6.91 & 7.22 & 7.43 & 7.54 & 7.58 & NS \\
\hline & 27-Jun-16 & 7.11 & 7.51 & 7.48 & 7.45 & 6.95 & NS \\
\hline & 30-Jun-16 & 7.17 & 7.48 & 7.51 & 7.46 & 6.87 & NS \\
\hline & 04-Jul-16 & 6.95 & 7.14 & 7.14 & 7.14 & 6.97 & NS \\
\hline & 07-Jul-16 & 6.87 & 7.11 & 7.08 & 7.07 & 6.81 & NS \\
\hline & 11-Jul-16 & 7.04 & 7.05 & 7.06 & 7.04 & 6.87 & NS \\
\hline & 19-Jul-16 & 6.94 & 7.11 & 7.13 & 7.10 & NA & NS \\
\hline & 26-Jul-16 & 6.96 & 7.14 & 7.16 & 7.10 & 6.84 & NS \\
\hline & 29-Jul-16 & 7.02 & 7.20 & 7.20 & 7.16 & 6.89 & NS \\
\hline & 10-Aug-16 & NA & 7.18 & 7.19 & 7.22 & 7.17 & NS \\
\hline & 22-Aug-16 & 6.84 & 7.86 & 7.24 & 7.22 & 7.81 & 7.26 \\
\hline
\end{tabular}

NS: Not Sampled 
Table 8-8: Raw Data - Lake Erie Pilot Plant (Cont.)

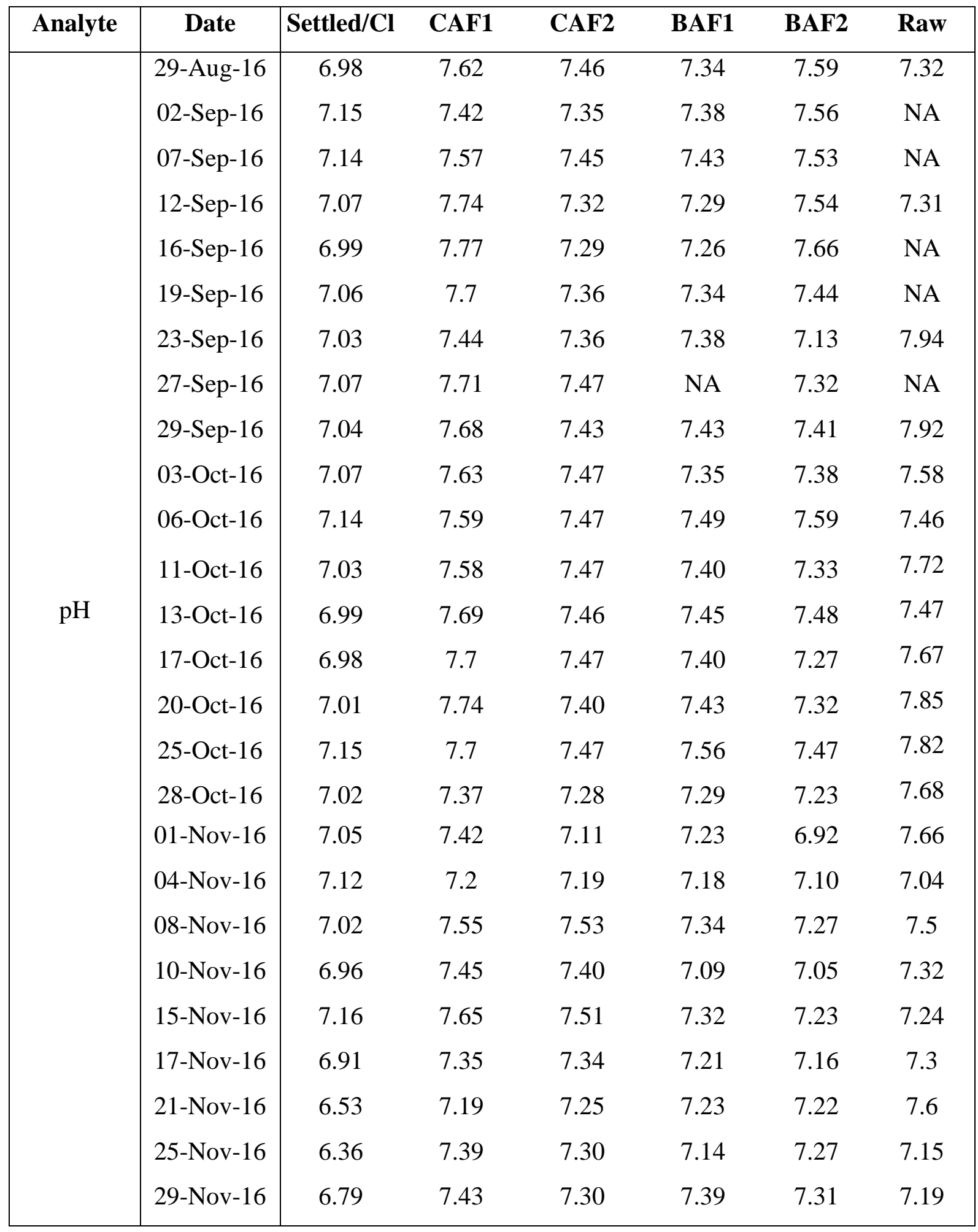

NA : Not Available 
Table 8-8: Raw Data - Lake Erie Pilot Plant (Cont.)

\begin{tabular}{|c|c|c|c|c|c|c|c|}
\hline Analyte & Date & Settled/Cl & CAF1 & CAF2 & BAF1 & BAF2 & Raw \\
\hline \multirow{3}{*}{$\mathrm{pH}$} & 02 -Dec-16 & 6.94 & 7.56 & 7.29 & 6.99 & 7.57 & 7.49 \\
\hline & 05-Dec-16 & 6.15 & 7.00 & 7.17 & 7.31 & 7.14 & 7.4 \\
\hline & 08-Dec-16 & 6.15 & 7.05 & 7.12 & 7.44 & 7.57 & 7.44 \\
\hline \multirow{23}{*}{$\begin{array}{c}\text { Turbidity } \\
\text { (NTU) }\end{array}$} & 08-Jan-16 & 1.050 & 0.337 & 0.140 & 0.184 & 0.157 & NS \\
\hline & 12-Jan-16 & 2.040 & 0.228 & 0.202 & 0.178 & 0.172 & NS \\
\hline & 15-Jan-16 & 1.060 & 0.273 & 0.178 & 0.203 & 0.106 & NS \\
\hline & 20-Jan-16 & 2.350 & 0.154 & 0.112 & 0.109 & 0.136 & NS \\
\hline & 25-Jan-16 & 1.500 & 0.110 & 0.092 & 0.097 & 0.091 & NS \\
\hline & 29-Jan-16 & NA & 0.267 & 0.182 & 0.152 & 0.187 & NS \\
\hline & 02-Feb-16 & 2.300 & 0.221 & 0.108 & 0.174 & 0.140 & NS \\
\hline & 05-Feb-16 & 3.830 & 0.382 & 0.306 & 0.287 & 0.209 & NS \\
\hline & 08-Feb-16 & 1.360 & 0.242 & 0.222 & 0.228 & 0.214 & NS \\
\hline & 12-Feb-16 & 1.410 & 0.195 & 0.199 & 0.195 & 0.206 & NS \\
\hline & 16-Feb-16 & 1.560 & 0.191 & 0.179 & 0.268 & 0.168 & NS \\
\hline & 18-Feb-16 & 1.120 & 0.137 & 0.145 & 0.127 & 0.147 & NS \\
\hline & 23-Feb-16 & 1.330 & 0.194 & 0.177 & 0.208 & 0.318 & NS \\
\hline & 26-Feb-16 & 1.210 & 0.152 & 0.228 & 0.151 & 0.188 & NS \\
\hline & 03-Mar-16 & 2.090 & 0.215 & 0.301 & 0.350 & 0.285 & NS \\
\hline & 08-Mar-16 & 1.720 & 0.149 & 0.124 & 0.103 & 0.121 & NS \\
\hline & 11-Mar-16 & 1.250 & 0.125 & 0.153 & 0.095 & 0.084 & NS \\
\hline & 15-Mar-16 & 1.710 & 0.091 & 0.103 & 0.119 & 0.117 & NS \\
\hline & 18-Mar-16 & 2.530 & 0.190 & 0.180 & 0.180 & 0.180 & NS \\
\hline & 22-Mar-16 & 1.780 & 0.129 & 0.122 & 0.137 & 0.096 & NS \\
\hline & 24-Mar-16 & 1.980 & 0.120 & 0.160 & 0.115 & 0.125 & NS \\
\hline & 29-Mar-16 & 2.35 & 0.145 & 0.142 & 0.190 & 0.121 & NS \\
\hline & 01-Apr-16 & 1.890 & 0.180 & 0.199 & 0.152 & 0.136 & NS \\
\hline
\end{tabular}

NS: Not Sampled; NA: Not Available 
Table 8-8: Raw Data - Lake Erie Pilot Plant (Cont.)

\begin{tabular}{|c|c|c|c|c|c|c|c|}
\hline Analyte & Date & Settled/Cl & CAF1 & CAF2 & BAF1 & BAF2 & Raw \\
\hline \multirow{26}{*}{$\begin{array}{c}\text { Turbidity } \\
\text { (NTU) }\end{array}$} & 06-Apr-16 & 2.270 & 0.220 & 0.181 & 0.174 & 0.172 & NS \\
\hline & 15-Apr-16 & 2.780 & 0.253 & 0.217 & 0.267 & 0.215 & NS \\
\hline & 20-Apr-16 & 2.670 & 0.198 & 0.185 & 0.201 & 0.189 & NS \\
\hline & 25-Apr-16 & 1.670 & 0.201 & 0.190 & 0.184 & 0.144 & NS \\
\hline & 29-Apr-16 & 1.620 & 0.223 & 0.200 & 0.169 & 0.143 & NS \\
\hline & 05-Мay-16 & 0.874 & 0.262 & 0.285 & 0.209 & 0.193 & NS \\
\hline & 09-Мay-16 & 1.120 & 0.168 & 0.185 & 0.163 & 0.168 & NS \\
\hline & 12-Маy-16 & 1.720 & 0.145 & 0.154 & 0.140 & 0.159 & NS \\
\hline & 17-May-16 & 1.020 & 0.160 & 0.173 & 0.195 & 0.175 & NS \\
\hline & 19-Мау-16 & 1.050 & 0.117 & 0.123 & 0.143 & 0.165 & NS \\
\hline & 24-Мay-16 & 0.729 & 0.135 & 0.131 & 0.137 & 0.145 & NS \\
\hline & 26-Мау-16 & NA & 0.136 & 0.138 & 0.141 & 0.136 & NS \\
\hline & 31-Мay-16 & 0.637 & 0.131 & 0.141 & 0.136 & 0.134 & NS \\
\hline & 02-Jun-16 & 0.667 & 0.182 & 0.139 & 0.154 & 0.110 & NS \\
\hline & 07-Jun-16 & 0.879 & 0.135 & 0.187 & 0.196 & 0.187 & NS \\
\hline & 10-Jun-16 & 0.740 & 0.147 & 0.160 & 0.143 & 0.148 & NS \\
\hline & 14-Jun-16 & 0.783 & 0.174 & 0.144 & 0.155 & 0.161 & NS \\
\hline & 16-Jun-16 & 0.734 & 0.235 & 0.185 & 0.179 & 0.158 & NS \\
\hline & 20-Jun-16 & 0.706 & 0.231 & 0.175 & 0.160 & 0.157 & NS \\
\hline & 27-Jun-16 & 0.811 & 0.154 & 0.184 & 0.182 & 0.187 & NS \\
\hline & 30-Jun-16 & 0.653 & 0.212 & 0.192 & 0.193 & 0.167 & NS \\
\hline & 04-Jul-16 & 0.611 & 0.167 & 0.200 & 0.136 & 0.121 & NS \\
\hline & 07-Jul-16 & 0.597 & 0.164 & 0.160 & 0.174 & 0.155 & NS \\
\hline & 11-Jul-16 & 2.170 & 0.226 & 0.161 & 0.206 & 0.211 & NS \\
\hline & 19-Jul-16 & 0.940 & 0.260 & 0.260 & 0.199 & 0.176 & NS \\
\hline & 26-Jul-16 & 1.960 & 0.181 & 0.191 & 0.168 & 0.186 & NS \\
\hline
\end{tabular}

NS: Not Sampled; NA: Not Available 
Table 8-8: Raw Data - Lake Erie Pilot Plant (Cont.)

\begin{tabular}{|c|c|c|c|c|c|c|c|}
\hline Analyte & Date & Settled/Cl & CAF1 & CAF2 & BAF1 & BAF2 & Raw \\
\hline \multirow{26}{*}{$\begin{array}{c}\text { Turbidity } \\
\text { (NTU) }\end{array}$} & 29-Jul-16 & 1.350 & 0.154 & 0.158 & 0.152 & 0.157 & NS \\
\hline & 10-Aug-16 & NA & 0.195 & 0.176 & 0.194 & 0.141 & NS \\
\hline & 22-Aug-16 & 1.400 & 0.980 & 0.134 & 0.130 & 0.910 & 1.510 \\
\hline & 29-Aug-16 & 1.430 & 0.960 & 0.201 & 0.198 & 0.905 & 1.040 \\
\hline & 02-Sep-16 & 1.160 & 0.935 & 0.108 & 0.087 & 0.860 & 2.350 \\
\hline & 07-Sep-16 & 1.820 & 1.650 & 0.200 & 0.280 & 1.780 & 3.150 \\
\hline & 12-Sep-16 & 8.240 & 5.660 & 0.321 & 0.189 & 11.200 & 5.740 \\
\hline & 16-Sep-16 & 15.600 & 4.750 & 0.291 & 0.141 & 4.210 & 7.650 \\
\hline & 19-Sep-16 & 9.470 & 3.180 & 0.176 & 0.158 & 2.740 & 5.670 \\
\hline & 23-Sep-16 & 17.400 & 3.570 & 0.488 & 0.159 & 2.370 & 2.040 \\
\hline & 27-Sep-16 & 3.710 & 14.000 & 0.263 & 0.270 & 9.290 & 21.400 \\
\hline & 29-Sep-16 & 3.610 & 15.400 & 0.520 & 0.520 & 12.800 & 30.500 \\
\hline & $03-$ Oct-16 & 5.690 & 9.430 & 0.380 & 0.185 & 8.340 & 17.000 \\
\hline & 06-Oct-16 & 6.290 & 40.000 & 1.170 & 0.171 & 33.900 & 98.600 \\
\hline & $11-$ Oct-16 & 3.460 & 3.940 & 0.353 & 0.159 & 4.140 & 15.500 \\
\hline & 13-Oct-16 & 4.000 & 16.500 & 0.539 & 0.259 & 14.500 & 40.200 \\
\hline & 17-Oct-16 & 3.440 & 14.700 & 0.473 & 0.172 & 15.800 & 27.200 \\
\hline & 20-Oct-16 & 4.380 & 9.220 & 0.369 & 0.257 & 8.820 & 15.400 \\
\hline & $25-O c t-16$ & 2.600 & 14.700 & 0.473 & 0.157 & 0.473 & 7.030 \\
\hline & 28-Oct-16 & 2.230 & 5.340 & 0.934 & 0.172 & 4.780 & 8.350 \\
\hline & 01-Nov-16 & 4.910 & 13.800 & 0.471 & 0.243 & 13.000 & 52.700 \\
\hline & 04-Nov-16 & 2.260 & 5.670 & 0.660 & 0.244 & 3.080 & 5.340 \\
\hline & 08-Nov-16 & 2.420 & 6.930 & 0.255 & 0.155 & 7.670 & 16.300 \\
\hline & 10-Nov-16 & 1.890 & 5.130 & 0.554 & 0.262 & 5.350 & 7.500 \\
\hline & 15-Nov-16 & 6.170 & 30.600 & 0.619 & 0.346 & 22.100 & 99.800 \\
\hline & 17-Nov-16 & 2.100 & 4.320 & 0.329 & 0.180 & 2.790 & 11.100 \\
\hline
\end{tabular}

NS: Not Sampled; NA: Not Available 
Table 8-8: Raw Data - Lake Erie Pilot Plant (Cont.)

\begin{tabular}{|c|c|c|c|c|c|c|c|}
\hline Analyte & Date & Settled/CI & CAF1 & CAF2 & BAF1 & BAF2 & Raw \\
\hline \multirow{6}{*}{$\begin{array}{c}\text { Turbidity } \\
\text { (NTU) }\end{array}$} & 21-Nov-16 & 6.820 & 16.800 & 0.482 & 0.203 & 16.100 & 80.100 \\
\hline & $25-N o v-16$ & 5.580 & 12.300 & 0.463 & 0.823 & 11.400 & 29.700 \\
\hline & 29-Nov-16 & 6.410 & 24.300 & 0.261 & 0.165 & 25.600 & 92.400 \\
\hline & 02-Dec-16 & 5.440 & 55.800 & 2.110 & 0.215 & 58.600 & 160.000 \\
\hline & 05-Dec-16 & 6.560 & 18.800 & 0.461 & 0.236 & 20.300 & 57.300 \\
\hline & 08-Dec-16 & 5.500 & 18.400 & 0.903 & 0.206 & 18.800 & 46.000 \\
\hline \multirow{19}{*}{$\begin{array}{l}\mathrm{UV}_{254} \\
\left(\mathrm{~cm}^{-1}\right)\end{array}$} & 08-Jan-16 & 0.025 & 0.021 & 0.022 & 0.020 & 0.020 & NS \\
\hline & 12-Jan-16 & 0.029 & 0.020 & 0.019 & 0.019 & 0.019 & NS \\
\hline & 15-Jan-16 & 0.016 & 0.012 & 0.011 & 0.011 & 0.013 & NS \\
\hline & 20-Jan-16 & 0.026 & 0.017 & 0.015 & 0.015 & 0.015 & NS \\
\hline & 25-Jan-16 & 0.023 & 0.019 & 0.019 & 0.021 & 0.013 & NS \\
\hline & 29-Jan-16 & NA & 0.015 & 0.015 & 0.015 & 0.013 & NS \\
\hline & 02-Feb-16 & 0.025 & 0.017 & 0.015 & 0.016 & 0.015 & NS \\
\hline & 05-Feb-16 & 0.030 & 0.021 & 0.022 & 0.020 & 0.019 & NS \\
\hline & 08-Feb-16 & 0.022 & 0.017 & 0.017 & 0.024 & 0.015 & NS \\
\hline & 12-Feb-16 & 0.024 & 0.020 & 0.020 & 0.020 & 0.022 & NS \\
\hline & 16-Feb-16 & 0.021 & 0.020 & 0.018 & 0.017 & 0.016 & NS \\
\hline & 18-Feb-16 & -0.002 & -0.003 & -0.006 & -0.005 & -0.006 & NS \\
\hline & 23-Feb-16 & 0.021 & 0.015 & 0.014 & 0.014 & 0.014 & NS \\
\hline & 26-Feb-16 & 0.021 & 0.015 & 0.016 & 0.017 & 0.017 & NS \\
\hline & 03-Mar-16 & 0.024 & 0.016 & 0.015 & 0.016 & 0.016 & NS \\
\hline & 08-Mar-16 & 0.023 & 0.016 & 0.018 & 0.016 & 0.016 & NS \\
\hline & 11-Mar-16 & 0.020 & 0.016 & 0.015 & 0.014 & 0.015 & NS \\
\hline & 15-Mar-16 & 0.020 & 0.013 & 0.013 & 0.015 & 0.015 & NS \\
\hline & 18-Mar-16 & 0.024 & 0.020 & 0.019 & 0.023 & 0.024 & NS \\
\hline
\end{tabular}

NS: Not Sampled; NA: Not Available 
Table 8-8: Raw Data - Lake Erie Pilot Plant (Cont.)

\begin{tabular}{|c|c|c|c|c|c|c|c|}
\hline Analyte & Date & Settled/Cl & CAF1 & CAF2 & BAF1 & BAF2 & Raw \\
\hline \multirow{26}{*}{$\begin{array}{l}\mathrm{UV}_{254} \\
\left(\mathrm{~cm}^{-1}\right)\end{array}$} & 22-Mar-16 & 0.022 & 0.020 & 0.019 & 0.020 & 0.020 & NS \\
\hline & 24-Mar-16 & 0.017 & 0.010 & 0.011 & 0.017 & 0.013 & NS \\
\hline & 29-Mar-16 & 0.022 & 0.013 & 0.014 & 0.018 & 0.017 & NS \\
\hline & $01-A p r-16$ & 0.012 & 0.004 & 0.004 & 0.007 & 0.016 & NS \\
\hline & 06-Apr-16 & 0.019 & 0.010 & 0.011 & 0.014 & 0.012 & NS \\
\hline & 15-Apr-16 & 0.028 & 0.018 & 0.018 & 0.021 & 0.020 & NS \\
\hline & 20-Apr-16 & 0.027 & 0.016 & 0.015 & 0.031 & 0.024 & NS \\
\hline & 25-Apr-16 & 0.025 & 0.020 & 0.018 & 0.019 & 0.021 & NS \\
\hline & 17-Мay-16 & 0.011 & 0.008 & 0.010 & 0.019 & 0.021 & NS \\
\hline & 19-Мay-16 & 0.017 & 0.014 & 0.013 & 0.015 & 0.014 & NS \\
\hline & 24-Мay-16 & 0.016 & 0.015 & 0.015 & 0.014 & 0.014 & NS \\
\hline & 26-Мay-16 & 0.020 & 0.017 & 0.030 & 0.017 & 0.015 & NS \\
\hline & 31-Мay-16 & 0.014 & 0.015 & 0.014 & 0.014 & 0.012 & NS \\
\hline & 02-Jun-16 & 0.014 & 0.010 & 0.011 & 0.016 & 0.020 & NS \\
\hline & 07-Jun-16 & 0.013 & 0.010 & 0.011 & 0.014 & 0.015 & NS \\
\hline & 10-Jun-16 & 0.013 & 0.015 & 0.016 & 0.021 & 0.023 & NS \\
\hline & 14-Jun-16 & 0.014 & 0.009 & 0.009 & 0.014 & 0.012 & NS \\
\hline & 16-Jun-16 & 0.016 & 0.018 & 0.018 & 0.015 & 0.015 & NS \\
\hline & 20-Jun-16 & 0.016 & 0.012 & 0.013 & 0.020 & 0.024 & NS \\
\hline & 27-Jun-16 & 0.020 & 0.018 & 0.018 & 0.018 & 0.019 & NS \\
\hline & 30-Jun-16 & 0.017 & 0.012 & 0.013 & 0.019 & 0.026 & NS \\
\hline & 04-Jul-16 & 0.013 & 0.010 & 0.008 & 0.012 & 0.011 & NS \\
\hline & 11-Jul-16 & 0.029 & 0.021 & 0.021 & 0.026 & 0.029 & NS \\
\hline & 19-Jul-16 & 0.012 & 0.011 & 0.011 & 0.009 & 0.007 & NS \\
\hline & 26-Jul-16 & 0.025 & 0.020 & 0.020 & 0.024 & 0.028 & NS \\
\hline & 29-Jul-16 & 0.010 & 0.007 & 0.006 & 0.006 & 0.006 & NS \\
\hline
\end{tabular}

NS: Not Sampled 
Table 8-8: Raw Data - Lake Erie Pilot Plant (Cont.)

\begin{tabular}{|c|c|c|c|c|c|c|c|}
\hline Analyte & Date & Settled/Cl & CAF1 & CAF2 & BAF1 & BAF2 & Raw \\
\hline \multirow{26}{*}{$\begin{array}{l}\mathrm{UV}_{254} \\
\left(\mathrm{~cm}^{-1}\right)\end{array}$} & 10-Aug-16 & NA & 0.029 & 0.028 & 0.105 & 0.087 & NS \\
\hline & 22-Aug-16 & 0.015 & 0.284 & 0.021 & 0.021 & 0.314 & 0.034 \\
\hline & 29-Aug-16 & 0.025 & 0.507 & 0.014 & 0.014 & 0.521 & 0.011 \\
\hline & 02-Sep-16 & 0.015 & 0.025 & 0.014 & 0.014 & 0.022 & 0.011 \\
\hline & 07-Sep-16 & 0.039 & 0.027 & 0.019 & 0.011 & 0.024 & 0.011 \\
\hline & 12-Sep-16 & 0.018 & 0.047 & 0.015 & 0.013 & 0.053 & 0.027 \\
\hline & 16-Sep-16 & 0.042 & 0.041 & 0.011 & 0.008 & 0.047 & 0.004 \\
\hline & 19-Sep-16 & 0.040 & 0.032 & 0.011 & 0.010 & 0.077 & 0.014 \\
\hline & 23-Sep-16 & 0.007 & 0.029 & 0.009 & 0.003 & 0.029 & 0.006 \\
\hline & 27-Sep-16 & 0.019 & 0.065 & 0.012 & NA & 0.049 & 0.009 \\
\hline & 29-Sep-16 & 0.012 & 0.069 & 0.007 & 0.007 & 0.068 & 0.007 \\
\hline & 03-Oct-16 & 0.019 & 0.055 & 0.012 & 0.012 & 0.060 & 0.009 \\
\hline & 06-Oct-16 & 0.025 & 0.100 & 0.011 & 0.011 & 0.134 & 0.012 \\
\hline & 11-Oct-16 & 0.025 & 0.058 & 0.014 & 0.011 & 0.077 & 0.015 \\
\hline & 13-Oct-16 & 0.016 & 0.083 & 0.013 & 0.008 & 0.081 & 0.047 \\
\hline & 17-Oct-16 & 0.020 & 0.063 & 0.006 & 0.007 & 0.049 & 0.004 \\
\hline & 20-Oct-16 & 0.023 & 0.048 & 0.010 & 0.008 & 0.061 & 0.011 \\
\hline & 25-Oct-16 & 0.019 & 0.063 & 0.006 & 0.011 & 0.006 & 0.006 \\
\hline & 28-Oct-16 & 0.013 & 0.067 & 0.009 & 0.007 & 0.067 & 0.001 \\
\hline & 01-Nov-16 & 0.015 & 0.063 & 0.009 & 0.006 & 0.067 & 0.006 \\
\hline & 04-Nov-16 & 0.010 & 0.058 & 0.007 & 0.010 & 0.028 & NA \\
\hline & 08-Nov-16 & 0.018 & 0.047 & 0.015 & 0.013 & 0.049 & 0.011 \\
\hline & 10-Nov-16 & 0.016 & 0.044 & 0.011 & 0.013 & 0.050 & 0.009 \\
\hline & 15-Nov-16 & 0.032 & 0.120 & 0.013 & 0.014 & 0.100 & 0.015 \\
\hline & 17-Nov-16 & 0.022 & 0.037 & 0.013 & 0.015 & 0.042 & 0.014 \\
\hline & 21-Nov-16 & 0.020 & 0.077 & 0.005 & 0.011 & 0.076 & 0.007 \\
\hline
\end{tabular}

NS: Not Sampled ; NA: Not Available 
Table 8-8: Raw Data - Lake Erie Pilot Plant (Cont.)

\begin{tabular}{|c|c|c|c|c|c|c|c|}
\hline Analyte & Date & Settled/Cl & CAF1 & CAF2 & BAF1 & BAF2 & Raw \\
\hline \multirow{5}{*}{$\begin{array}{l}\mathrm{UV}_{254} \\
\left(\mathrm{~cm}^{-1}\right)\end{array}$} & 25-Nov-16 & 0.036 & 0.079 & 0.015 & 0.015 & 0.063 & 0.011 \\
\hline & 29-Nov-16 & 0.029 & 0.255 & 0.017 & 0.012 & 0.099 & 0.011 \\
\hline & 02-Dec-16 & 0.025 & 0.279 & 0.014 & 0.012 & 0.195 & 0.012 \\
\hline & 05-Dec-16 & 0.027 & 0.112 & 0.016 & 0.015 & 0.096 & 0.011 \\
\hline & 08-Dec-16 & 0.019 & 0.074 & 0.007 & 0.006 & 0.079 & 0.007 \\
\hline \multirow{21}{*}{$\begin{array}{c}\text { Cl- } \\
\text { Residual } \\
(\mathrm{mg} / \mathrm{L})\end{array}$} & 08-Jan-16 & 0.28 & 0.27 & 0.28 & 0.26 & 0.22 & $\mathrm{NS}$ \\
\hline & 12-Jan-16 & 0.37 & 0.18 & 0.24 & 0.31 & 0.27 & NS \\
\hline & 15-Jan-16 & 0.31 & 0.18 & 0.27 & 0.23 & 0.31 & NS \\
\hline & 20-Jan-16 & 0.41 & 0.24 & 0.28 & 0.23 & 0.29 & NS \\
\hline & 25-Jan-16 & 0.10 & 0.04 & 0.04 & 0.06 & 0.18 & NS \\
\hline & 29-Jan-16 & 0.50 & 0.35 & 0.37 & 0.34 & 0.35 & NS \\
\hline & 02-Feb-16 & 0.47 & 0.30 & 0.29 & 0.26 & 0.37 & NS \\
\hline & 05-Feb-16 & 0.50 & 0.26 & 0.21 & 0.29 & 0.27 & NS \\
\hline & 08-Feb-16 & 0.15 & 0.23 & 0.23 & 0.18 & 0.12 & NS \\
\hline & 12-Feb-16 & 0.26 & 0.21 & 0.23 & 0.18 & 0.27 & NS \\
\hline & 16-Feb-16 & 0.48 & 0.19 & 0.26 & 0.27 & 0.24 & NS \\
\hline & $18-F e b-16$ & 0.96 & 0.56 & 0.52 & 0.66 & 0.74 & NS \\
\hline & 23-Feb-16 & 0.71 & 0.38 & 0.39 & 0.36 & 0.39 & NS \\
\hline & 26-Feb-16 & 0.68 & 0.42 & 0.42 & 0.47 & 0.42 & NS \\
\hline & 03-Mar-16 & 0.35 & 0.26 & 0.22 & 0.17 & 0.16 & NS \\
\hline & 08-Mar-16 & 0.46 & 0.43 & 0.35 & 0.56 & 0.50 & NS \\
\hline & 11-Mar-16 & 0.09 & 0.16 & 0.09 & 0.16 & 0.14 & NS \\
\hline & 15-Mar-16 & 0.35 & 0.29 & 0.29 & 0.11 & 0.16 & NS \\
\hline & 18-Mar-16 & 0.36 & 0.26 & 0.27 & 0.01 & 0.03 & NS \\
\hline & 22-Mar-16 & 0.08 & 0.12 & 0.14 & 0.01 & 0.02 & NS \\
\hline & 24-Mar-16 & 0.63 & 0.28 & 0.35 & 0.02 & 0.01 & NS \\
\hline
\end{tabular}

NS: Not Sampled 
Table 8-8: Raw Data - Lake Erie Pilot Plant (Cont.)

\begin{tabular}{|c|c|c|c|c|c|c|c|}
\hline Analyte & Date & Settled/Cl & CAF1 & CAF2 & BAF1 & BAF2 & Raw \\
\hline \multirow{26}{*}{$\begin{array}{c}\text { Cl- } \\
\text { Residual } \\
(\mathrm{mg} / \mathrm{L})\end{array}$} & 29-Mar-16 & 0.230 & 0.13 & 0.16 & 0.05 & 0.04 & NS \\
\hline & 01-Apr-16 & 0.63 & 0.44 & 0.51 & 0.01 & 0.02 & NS \\
\hline & 06-Apr-16 & 0.29 & 0.18 & 0.22 & 0.01 & 0.02 & NS \\
\hline & 15-Apr-16 & 0.30 & 0.15 & 0.08 & 0.07 & 0.14 & NS \\
\hline & $20-A p r-16$ & 0.05 & 0.08 & 0.13 & 0.02 & 0.02 & NS \\
\hline & 25-Apr-16 & 0.24 & 0.08 & 0.13 & 0.02 & 0.03 & NS \\
\hline & 29-Apr-16 & 0.65 & 0.40 & 0.10 & 0.00 & 0.01 & NS \\
\hline & 05-May-16 & 0.46 & 0.37 & 0.37 & 0.02 & 0.02 & NS \\
\hline & 09-Мау-16 & 0.25 & 0.11 & 0.19 & 0.01 & 0.01 & NS \\
\hline & 12-Мay-16 & 0.29 & 0.15 & 0.16 & 0.02 & 0.00 & NS \\
\hline & 17-Мау-16 & 1.04 & 0.88 & 0.91 & 0.01 & 0.01 & NS \\
\hline & 19-Мay-16 & 0.26 & 0.15 & 0.17 & 0.01 & 0.01 & NS \\
\hline & 24-Мау-16 & 0.18 & 0.14 & 0.15 & 0.02 & 0.02 & NS \\
\hline & 26-Мау-16 & 0.74 & 0.69 & 0.77 & 0.02 & 0.32 & NS \\
\hline & 31-May-16 & 0.10 & 0.02 & 0.07 & 0.02 & 0.02 & NS \\
\hline & 02-Jun-16 & 0.24 & 0.16 & 0.18 & 0.04 & 0.03 & NS \\
\hline & 07-Jun-16 & 0.01 & 0.02 & 0.01 & 0.01 & 0.01 & NS \\
\hline & 10-Jun-16 & 0.18 & 0.13 & 0.12 & 0.01 & 0.01 & NS \\
\hline & 14-Jun-16 & 0.08 & 0.03 & 0.05 & 0.03 & 0.02 & NS \\
\hline & 16-Jun-16 & 0.07 & 0.07 & 0.07 & 0.02 & 0.03 & NS \\
\hline & 20-Jun-16 & 0.14 & 0.07 & 0.10 & 0.01 & 0.01 & NS \\
\hline & 27-Jun-16 & 0.49 & 0.32 & 0.31 & 0.00 & 0.01 & NS \\
\hline & 30-Jun-16 & 0.27 & 0.13 & 0.14 & 0.00 & 0.01 & NS \\
\hline & 04-Jul-16 & 0.19 & 0.09 & 0.10 & 0.02 & 0.02 & NS \\
\hline & 07-Jul-16 & 0.11 & 0.09 & 0.10 & 0.03 & 0.01 & NS \\
\hline & 11-Jul-16 & 0.02 & 0.01 & 0.00 & 0.01 & 0.03 & NS \\
\hline
\end{tabular}

NS: Not Sampled 
Table 8-8: Raw Data - Lake Erie Pilot Plant (Cont.)

\begin{tabular}{|c|c|cccccc|}
\hline Analyte & Date & Settled/Cl & CAF1 & CAF2 & BAF1 & BAF2 & Raw \\
\hline \multirow{6}{*}{} & 19-Jul-16 & 0.01 & 0.01 & 0.01 & 0.01 & 0.03 & NS \\
& 26-Jul-16 & 0.00 & 0.01 & 0.00 & 0.00 & 0.00 & NS \\
& 29-Jul-16 & 0.02 & 0.02 & 0.02 & 0.02 & 0.02 & NS \\
& 10-Aug-16 & NA & 0.00 & 0.00 & 0.00 & 0.00 & NS \\
& 22-Aug-16 & 0.30 & 0.00 & 0.01 & 0.01 & 0.00 & 0.00 \\
& 29-Aug-16 & 0.13 & 0.00 & 0.01 & 0.01 & 0.01 & 0.01 \\
& 02-Sep-16 & 0.05 & 0.01 & 0.01 & 0.01 & 0.01 & 0.02 \\
& 07-Sep-16 & 0.02 & 0.01 & 0.01 & 0.00 & 0.02 & 0.03 \\
& 12-Sep-16 & 0.02 & 0.02 & 0.02 & 0.02 & 0.04 & 0.01 \\
& 16-Sep-16 & 0.84 & 0.01 & 0.02 & 0.02 & 0.00 & 0.78 \\
& 19-Sep-16 & 0.06 & 0.01 & 0.01 & 0.00 & 0.01 & 0.00 \\
& 23-Sep-16 & 0.02 & 0.01 & 0.03 & 0.02 & 0.01 & 0.02 \\
& 27-Sep-16 & 0.04 & 0.01 & 0.02 & NA & 0.01 & 0.01 \\
& 29-Sep-16 & 0.02 & 0.00 & 0.03 & 0.03 & 0.00 & 0.01 \\
& 03-Oct-16 & 0.03 & 0.01 & 0.01 & 0.01 & 0.00 & 0.01 \\
& 06-Oct-16 & 0.04 & 0.00 & 0.02 & 0.02 & 0.00 & 0.00 \\
& 11-Oct-16 & 0.03 & 0.01 & 0.02 & 0.01 & 0.01 & 0.02 \\
& 13-Oct-16 & 0.58 & 0.00 & 0.06 & 0.03 & 0.01 & 0.00 \\
& 17-Oct-16 & 0.08 & 0.02 & 0.03 & 0.02 & 0.01 & 0.00 \\
& 20-Oct-16 & 0.02 & 0.01 & 0.02 & 0.01 & 0.00 & 0.00 \\
& 25-Oct-16 & 0.03 & 0.02 & 0.03 & 0.01 & 0.03 & 0.01 \\
& 28-Oct-16 & 0.25 & 0.01 & 0.01 & 0.01 & 0.00 & 0.00 \\
& 01-Nov-16 & 0.07 & 0.00 & 0.00 & 0.03 & 0.01 & 0.00 \\
& 04-Nov-16 & 0.13 & 0.00 & 0.01 & 0.16 & 0.00 & 0.01 \\
& 08-Nov-16 & 0.05 & 0.01 & 0.04 & 0.06 & 0.00 & 0.00 \\
& $10-$-Nov-16 & 0.10 & 0.00 & 0.02 & 0.03 & 0.00 & 0.01 \\
\hline
\end{tabular}

NS: Not Sampled; NA: Not Available 
Table 8-8: Raw Data - Lake Erie Pilot Plant (Cont.)

\begin{tabular}{|c|c|cccccc|}
\hline Analyte & Date & Settled/Cl & CAF1 & CAF2 & BAF1 & BAF2 & Raw \\
\hline \multirow{6}{*}{ Cl- } & 15-Nov-16 & 0.15 & 0.00 & 0.16 & 0.18 & 0.00 & 0.00 \\
Residual & 17-Nov-16 & 0.05 & 0.00 & 0.03 & 0.04 & 0.00 & 0.01 \\
(mg/L) & 21-Nov-16 & 0.38 & 0.00 & 0.62 & 0.64 & 0.00 & 0.01 \\
& 29-Nov-16 & 0.03 & 0.00 & 0.03 & 0.04 & 0.00 & 0.02 \\
& 02-Dec-16 & 0.03 & 0.00 & 0.01 & 0.02 & 0.00 & 0.00 \\
& 05-Dec-16 & 0.34 & 0.01 & 0.30 & 0.2 & 0.01 & 0.02 \\
& 08-Dec-16 & 0.03 & 0.01 & 0.02 & 0.02 & 0.00 & 0.01 \\
\hline \multirow{6}{*}{ DOC } & 23-Oct-15 & 1.4 & 1.4 & 1.4 & 1.4 & 1.4 & NS \\
& 27-Nov-15 & 1.5 & 1.5 & 1.5 & 1.3 & 1.5 & NS \\
& 12-Jan-16 & 1.6 & 1.6 & 1.6 & 1.6 & 1.6 & NS \\
& 25-Jan-16 & 1.6 & 1.6 & 1.6 & 1.6 & 1.6 & NS \\
& 02-Feb-16 & 1.5 & 1.6 & 1.5 & 1.5 & 1.5 & NS \\
& 09-Feb-16 & 1.6 & 1.6 & 1.6 & 1.7 & 1.7 & NS \\
& 18-Feb-16 & 1.7 & 1.8 & 1.8 & 1.8 & 1.7 & NS \\
& 01-Mar-16 & 1.5 & 1.6 & 1.5 & 1.6 & 1.5 & NS \\
& 08-Mar-16 & 1.6 & 1.7 & 1.6 & 1.7 & 1.6 & NS \\
& 15-Mar-16 & 1.6 & 1.5 & 1.6 & 1.6 & 1.6 & NS \\
& 22-Mar-16 & 1.4 & 1.5 & 1.4 & 1.5 & 1.4 & NS \\
& 06-Apr-16 & 1.6 & 1.7 & 1.7 & 1.6 & 1.6 & NS \\
& 20-Apr-16 & 1.7 & 1.8 & 1.7 & 1.7 & 1.7 & NS \\
& 17-May-16 & 1.7 & 1.8 & 1.7 & 1.8 & 1.7 & NS \\
& 25-May-16 & 1.5 & 1.6 & 1.5 & 1.6 & 1.5 & NS \\
& 03-Jun-16 & 1.7 & 1.8 & 1.7 & 1.7 & 1.6 & NS \\
& 07-Jun-16 & 1.5 & 1.5 & 1.5 & 1.6 & 1.5 & NS \\
& 15-Jun-16 & 1.5 & 1.5 & 1.5 & 1.5 & 1.5 & NS \\
\hline NS: Not Sand & & & & & & &
\end{tabular}

NS: Not Sampled 
Table 8-8: Raw Data - Lake Erie Pilot Plant (Cont.)

\begin{tabular}{|c|c|c|c|c|c|c|c|}
\hline Analyte & Date & Settled/Cl & CAF1 & CAF2 & BAF1 & BAF2 & Raw \\
\hline \multirow{16}{*}{$\begin{array}{c}\text { DOC } \\
(\mathrm{mg} / \mathrm{L})\end{array}$} & 21-Jun-16 & 1.6 & 1.6 & 1.6 & 1.6 & 1.6 & NS \\
\hline & 29-Jun-16 & 1.5 & 1.5 & 1.5 & 1.5 & 1.5 & NS \\
\hline & 06-Jul-16 & 1.5 & 1.5 & 1.5 & 1.5 & 1.5 & NS \\
\hline & 19-Jul-16 & 1.5 & 1.6 & 1.8 & 1.6 & 1.6 & NS \\
\hline & 26-Jul-16 & 1.5 & 1.6 & 1.5 & 1.5 & 1.5 & NS \\
\hline & 03-Aug-16 & 1.6 & 1.5 & 1.6 & 1.5 & 1.5 & 2.2 \\
\hline & 10-Aug-16 & 1.6 & 1.7 & 1.6 & 1.6 & 1.6 & 2.2 \\
\hline & 17-Aug-16 & 1.6 & 2.3 & 1.7 & 1.6 & 2.3 & 2.2 \\
\hline & 24-Aug-16 & 1.6 & 2.1 & 1.5 & 1.5 & 2.1 & 2.0 \\
\hline & 29-Aug-16 & 1.5 & 2.2 & 1.4 & 1.4 & 2.2 & 2.2 \\
\hline & 07-Sep-16 & 1.6 & 2.3 & 1.7 & 1.6 & 2.3 & 2.3 \\
\hline & 21-Sep-16 & 1.8 & 2.5 & 1.8 & 1.9 & 2.4 & 2.5 \\
\hline & 28-Sep-16 & 1.6 & 2.2 & 1.6 & 1.7 & 2.3 & 2.3 \\
\hline & 05 -Oct-16 & 1.5 & 2.1 & 1.6 & 1.5 & 2.0 & 2.1 \\
\hline & $12-$ Oct-16 & 1.5 & 2.1 & 1.4 & 1.5 & 2.1 & 2.2 \\
\hline & 26-Oct-16 & 1.4 & 2.1 & 1.4 & 1.4 & 2.1 & 2.2 \\
\hline \multirow{10}{*}{$\begin{array}{l}\text { Total } \\
\text { THMs } \\
(\mu \mathrm{g} / \mathrm{L})\end{array}$} & 08-Dec-15 & 19.7 & 24.1 & 24.6 & 24.6 & 26.2 & NS \\
\hline & 08-Dec-15 & 23.6 & 25.0 & 21.7 & 21.7 & 25.0 & NS \\
\hline & 02-Feb-16 & 20.1 & 18.9 & 18.4 & 18.9 & 19.8 & NS \\
\hline & 02-Feb-16 & 20.1 & 19.2 & 18.8 & 19.8 & 20.8 & NS \\
\hline & 20-Apr-16 & 23.9 & 24.5 & 24.2 & 23.1 & 21.0 & NS \\
\hline & 20-Apr-16 & 23.9 & 23.5 & 23.3 & 21.9 & 21.7 & NS \\
\hline & 17-Мау-16 & 31.2 & 30.9 & 24.2 & 24.5 & 22.2 & NS \\
\hline & 17-Мау-16 & 27.2 & 26.8 & 26.2 & 23.7 & 25.4 & NS \\
\hline & 16-Jul-16 & 27.3 & 24.2 & 21.1 & 24.2 & 30.7 & NS \\
\hline & 16-Jul-16 & 26.3 & 20.1 & 22.8 & 23.5 & 29.1 & NS \\
\hline
\end{tabular}

NS: Not Sampled 
Table 8-8: Raw Data - Lake Erie Pilot Plant (Cont.)

\begin{tabular}{|c|c|c|c|c|c|c|c|}
\hline Analyte & Date & Settled/CI & CAF1 & CAF2 & BAF1 & BAF2 & Raw \\
\hline \multirow{6}{*}{$\begin{array}{l}\text { Total } \\
\text { THMs } \\
(\mu \mathrm{g} / \mathrm{L})\end{array}$} & 15-Aug-16 & 21.4 & 20.7 & 20.3 & 19.9 & 19.4 & 24.5 \\
\hline & 15-Aug-16 & 20.9 & 23.3 & 18.1 & 17.9 & 18.7 & 25.8 \\
\hline & 19-Sep-16 & 24.5 & 21.2 & 20.8 & 24.2 & 21.1 & 25.1 \\
\hline & 19-Sep-16 & 24.8 & 21.6 & 20.7 & 24.6 & 21.6 & 24.7 \\
\hline & 05-Nov-16 & 22.9 & 20.1 & 19.9 & 23.1 & 21.6 & 23.4 \\
\hline & 05-Nov-16 & 22.6 & 19.4 & 18.5 & 22.1 & 19.8 & 22.7 \\
\hline \multirow{14}{*}{$\begin{array}{l}\text { Total } \\
\text { HAAs } \\
(\mu \mathrm{g} / \mathrm{L})\end{array}$} & 02-Feb-16 & 13.1 & 14.7 & 13.3 & 12.5 & 15.3 & NS \\
\hline & 02-Feb-16 & 14.7 & 13.9 & 13.1 & 13.7 & 15.0 & NS \\
\hline & 20-Apr-16 & 4.36 & 4.09 & 4.79 & 4.38 & 4.80 & NS \\
\hline & 20-Apr-16 & NA & 5.34 & 4.81 & 4.56 & 4.07 & NS \\
\hline & 17-Мay-16 & 31.2 & 30.9 & 24.2 & 24.5 & 22.2 & NS \\
\hline & 17-Мay-16 & 27.2 & 26.8 & 26.2 & 23.7 & 25.4 & NS \\
\hline & 16-Jul-16 & 27.3 & 24.2 & 21.1 & 24.2 & 30.7 & NS \\
\hline & 16-Jul-16 & 26.3 & 20.1 & 22.8 & 23.5 & 29.1 & NS \\
\hline & 15-Aug-16 & 21.4 & 20.7 & 20.3 & 19.9 & 19.4 & 24.5 \\
\hline & 15-Aug-16 & 20.9 & 23.3 & 18.1 & 17.9 & 18.7 & 25.8 \\
\hline & 19-Sep-16 & 24.5 & 21.2 & 20.8 & 24.2 & 21.1 & 25.1 \\
\hline & 19-Sep-16 & 24.8 & 21.6 & 20.7 & 24.6 & 21.6 & 24.7 \\
\hline & 05-Nov-16 & 22.9 & 20.1 & 19.9 & 23.1 & 21.6 & 23.4 \\
\hline & 05-Nov-16 & 22.6 & 19.4 & 18.5 & 22.1 & 19.8 & 22.7 \\
\hline \multirow{6}{*}{$\begin{array}{c}\text { Manganese } \\
(\mu \mathrm{g} / \mathrm{L})\end{array}$} & 05-Jul-16 & $<\mathrm{MDL}$ & $<\mathrm{MDL}$ & $<\mathrm{MDL}$ & $<\mathrm{MDL}$ & $<\mathrm{MDL}$ & NS \\
\hline & 26-Jul-16 & $<\mathrm{MDL}$ & $<\mathrm{MDL}$ & $<\mathrm{MDL}$ & $<\mathrm{MDL}$ & $<\mathrm{MDL}$ & NS \\
\hline & 02-Aug-16 & $<\mathrm{MDL}$ & $<\mathrm{MDL}$ & $<\mathrm{MDL}$ & $<\mathrm{MDL}$ & $<\mathrm{MDL}$ & NS \\
\hline & 10-Aug-16 & $<\mathrm{MDL}$ & $<\mathrm{MDL}$ & $<\mathrm{MDL}$ & 18.5 & 19.7 & $<\mathrm{MDL}$ \\
\hline & 18-Aug-16 & $<\mathrm{MDL}$ & 34.1 & $<\mathrm{MDL}$ & $<\mathrm{MDL}$ & 18.6 & $<\mathrm{MDL}$ \\
\hline & 22-Aug-16 & $<\mathrm{MDL}$ & 76.6 & $<\mathrm{MDL}$ & $<\mathrm{MDL}$ & 59.9 & $<\mathrm{MDL}$ \\
\hline
\end{tabular}

NS: Not Sampled; NA: Not Available ; <MDL: Below Minimum Detection Limit 
Table 8-8: Raw Data - Lake Erie Pilot Plant (Cont.)

\begin{tabular}{|c|c|c|c|c|c|c|c|}
\hline Analyte & Date & Settled/Cl & CAF1 & CAF2 & BAF1 & BAF2 & Raw \\
\hline \multirow{17}{*}{$\begin{array}{c}\text { Manganese } \\
(\mu \mathrm{g} / \mathrm{L})\end{array}$} & 29-Aug-16 & $<\mathrm{MDL}$ & 278.0 & $<\mathrm{MDL}$ & $<\mathrm{MDL}$ & 169.8 & $<\mathrm{MDL}$ \\
\hline & 02-Sep-16 & $<\mathrm{MDL}$ & 385.3 & $<\mathrm{MDL}$ & $<\mathrm{MDL}$ & 146.3 & $<\mathrm{MDL}$ \\
\hline & 09-Sep-16 & $<\mathrm{MDL}$ & 16.2 & $<\mathrm{MDL}$ & $<\mathrm{MDL}$ & $<\mathrm{MDL}$ & $<\mathrm{MDL}$ \\
\hline & 23-Sep-16 & $<\mathrm{MDL}$ & 24.3 & $<\mathrm{MDL}$ & $<\mathrm{MDL}$ & 44.2 & $<\mathrm{MDL}$ \\
\hline & 27-Sep-16 & $<\mathrm{MDL}$ & $<\mathrm{MDL}$ & $<\mathrm{MDL}$ & $<\mathrm{MDL}$ & 83.7 & 55.9 \\
\hline & 29-Sep-16 & $<\mathrm{MDL}$ & $<\mathrm{MDL}$ & $<\mathrm{MDL}$ & $<\mathrm{MDL}$ & 51.3 & 35.0 \\
\hline & 03-Oct-16 & 22.6 & 79.3 & $<\mathrm{MDL}$ & $<\mathrm{MDL}$ & 390.7 & $<\mathrm{MDL}$ \\
\hline & 06-Oct-16 & $<\mathrm{MDL}$ & $<\mathrm{MDL}$ & $<\mathrm{MDL}$ & $<\mathrm{MDL}$ & 25.6 & $<\mathrm{MDL}$ \\
\hline & 11-Oct-16 & $<\mathrm{MDL}$ & 12.0 & $<\mathrm{MDL}$ & $<\mathrm{MDL}$ & 104.9 & $<\mathrm{MDL}$ \\
\hline & 13-Oct-16 & $<\mathrm{MDL}$ & 11.6 & $<\mathrm{MDL}$ & $<\mathrm{MDL}$ & 26.1 & 23.4 \\
\hline & 17-Oct-16 & $<\mathrm{MDL}$ & $<\mathrm{MDL}$ & $<\mathrm{MDL}$ & $<\mathrm{MDL}$ & 59.2 & 12.7 \\
\hline & 20-Oct-16 & $<\mathrm{MDL}$ & $<\mathrm{MDL}$ & $<\mathrm{MDL}$ & $<\mathrm{MDL}$ & 15.8 & 11.8 \\
\hline & 25-Oct-16 & $<\mathrm{MDL}$ & 247.2 & $<\mathrm{MDL}$ & $<\mathrm{MDL}$ & 504.5 & $<\mathrm{MDL}$ \\
\hline & 28-Oct-16 & $<\mathrm{MDL}$ & 23.0 & $<\mathrm{MDL}$ & $<\mathrm{MDL}$ & 36.9 & $<\mathrm{MDL}$ \\
\hline & 01-Nov-16 & $<\mathrm{MDL}$ & 10.1 & $<\mathrm{MDL}$ & $<\mathrm{MDL}$ & 12.2 & 58.6 \\
\hline & 04-Nov-16 & $<\mathrm{MDL}$ & $<\mathrm{MDL}$ & $<\mathrm{MDL}$ & $<\mathrm{MDL}$ & $<\mathrm{MDL}$ & $<\mathrm{MDL}$ \\
\hline & 08-Nov-16 & $<\mathrm{MDL}$ & $<\mathrm{MDL}$ & $<\mathrm{MDL}$ & 97.8 & $<\mathrm{MDL}$ & $<\mathrm{MDL}$ \\
\hline \multirow{9}{*}{$\begin{array}{c}\text { Iron } \\
(\mu \mathrm{g} / \mathrm{L})\end{array}$} & 05-Jul-16 & $<\mathrm{MDL}$ & $<\mathrm{MDL}$ & 12.4 & $<\mathrm{MDL}$ & $<\mathrm{MDL}$ & NS \\
\hline & 26-Jul-16 & 10.4 & $<\mathrm{MDL}$ & $<\mathrm{MDL}$ & $<\mathrm{MDL}$ & $<\mathrm{MDL}$ & NS \\
\hline & 02-Aug-16 & $<\mathrm{MDL}$ & $<\mathrm{MDL}$ & $<\mathrm{MDL}$ & $<\mathrm{MDL}$ & $<\mathrm{MDL}$ & NS \\
\hline & 10-Aug-16 & $<\mathrm{MDL}$ & 10.6 & $<\mathrm{MDL}$ & $<\mathrm{MDL}$ & $<\mathrm{MDL}$ & $<\mathrm{MDL}$ \\
\hline & 18-Aug-16 & $<\mathrm{MDL}$ & $<\mathrm{MDL}$ & $<\mathrm{MDL}$ & $<\mathrm{MDL}$ & $<\mathrm{MDL}$ & $<\mathrm{MDL}$ \\
\hline & 22-Aug-16 & $<\mathrm{MDL}$ & $<\mathrm{MDL}$ & $<\mathrm{MDL}$ & 12.4 & $<\mathrm{MDL}$ & $<\mathrm{MDL}$ \\
\hline & 29-Aug-16 & $<\mathrm{MDL}$ & 12.9 & $<\mathrm{MDL}$ & $<\mathrm{MDL}$ & $<\mathrm{MDL}$ & $<\mathrm{MDL}$ \\
\hline & 02-Sep-16 & $<\mathrm{MDL}$ & $<\mathrm{MDL}$ & $<\mathrm{MDL}$ & $<\mathrm{MDL}$ & $<\mathrm{MDL}$ & $<\mathrm{MDL}$ \\
\hline & 09-Sep-16 & $<\mathrm{MDL}$ & $<\mathrm{MDL}$ & $<\mathrm{MDL}$ & $<\mathrm{MDL}$ & $<\mathrm{MDL}$ & $<\mathrm{MDL}$ \\
\hline
\end{tabular}

NS: Not Sampled; <MDL: Below Minimum Detection Limit 
Table 8-8: Raw Data - Lake Erie Pilot Plant (Cont.)

\begin{tabular}{|c|c|c|c|c|c|c|c|}
\hline Analyte & Date & Settled/Cl & CAF1 & CAF2 & BAF1 & BAF2 & Raw \\
\hline \multirow{14}{*}{$\begin{array}{c}\text { Iron } \\
(\mu \mathrm{g} / \mathrm{L})\end{array}$} & 23-Sep-16 & $<\mathrm{MDL}$ & 12.1 & $<\mathrm{MDL}$ & $<\mathrm{MDL}$ & $<\mathrm{MDL}$ & $<\mathrm{MDL}$ \\
\hline & 27-Sep-16 & 13.7 & $<\mathrm{MDL}$ & $<\mathrm{MDL}$ & $<\mathrm{MDL}$ & $<\mathrm{MDL}$ & 693.0 \\
\hline & 29-Sep-16 & 21.8 & $<\mathrm{MDL}$ & $<\mathrm{MDL}$ & $<\mathrm{MDL}$ & 219.3 & 556.0 \\
\hline & 03-Oct-16 & $<\mathrm{MDL}$ & $<\mathrm{MDL}$ & $<\mathrm{MDL}$ & $<\mathrm{MDL}$ & $<\mathrm{MDL}$ & 133.9 \\
\hline & 06-Oct-16 & $<\mathrm{MDL}$ & 85.8 & $<\mathrm{MDL}$ & $<\mathrm{MDL}$ & 62.4 & 109.0 \\
\hline & 11-Oct-16 & $<\mathrm{MDL}$ & $<\mathrm{MDL}$ & $<\mathrm{MDL}$ & $<\mathrm{MDL}$ & 28.7 & 68.0 \\
\hline & 13-Oct-16 & 13.9 & 342.5 & $<\mathrm{MDL}$ & $<\mathrm{MDL}$ & 151.7 & 286.1 \\
\hline & 17-Oct-16 & 15.7 & 166.8 & $<\mathrm{MDL}$ & $<\mathrm{MDL}$ & 164.3 & 273.6 \\
\hline & 20-Oct-16 & 19.4 & 125.5 & $<\mathrm{MDL}$ & $<\mathrm{MDL}$ & 109.2 & 224.8 \\
\hline & $25-O c t-16$ & $<\mathrm{MDL}$ & 73.3 & $<\mathrm{MDL}$ & $<\mathrm{MDL}$ & 61.5 & 82.3 \\
\hline & $28-O c t-16$ & $<\mathrm{MDL}$ & 52.6 & $<\mathrm{MDL}$ & $<\mathrm{MDL}$ & 75.8 & 48.4 \\
\hline & 01-Nov-16 & $<\mathrm{MDL}$ & 109.4 & $<\mathrm{MDL}$ & $<\mathrm{MDL}$ & 123.4 & 606.4 \\
\hline & 04-Nov-16 & $<\mathrm{MDL}$ & 53.3 & 17.3 & $<\mathrm{MDL}$ & 57.8 & 44.8 \\
\hline & 08-Nov-16 & $<\mathrm{MDL}$ & 125.2 & $<\mathrm{MDL}$ & 76.5 & 89.2 & 143.2 \\
\hline
\end{tabular}

<MDL: Below Minimum Detection Limit 


\subsection{Sample Quality Assurance/Quality Control (QA/QC) Charts}

QA/QC charts were generated by analyzing 9 samples prepared at a concentration equivalent to the expected concentrations in the samples being analyzed after each new calibration. Check standards are prepared at the same concentration, and analyzed after every 10 samples. The check standards are compared to the mean and standard deviation calculated from the original 8 samples as per Standard Method 1020 (APHA, 2005). The calibration is considered unacceptable if:

- 2 consecutive measurements fall outside of the control limit (CL) of the mean \pm 3 times the standard deviation;

- 3 out of 4 consecutive measurements were outside the warning limits (WL) of the mean \pm 2 times the standard deviation;

- 5 out of 6 consecutive measurements were outside of the mean \pm the standard deviation;

- 5 out of 6 consecutive measurements exhibited an increasing or decreasing trend; or,

- 7 consecutive samples were greater, or less, than the mean

If any of these conditions were met, a new calibration curve was generated and the samples were reanalyzed. 
Table 8-9: THM Quality Control Chart Values

\begin{tabular}{|c|c|c|c|c|}
\hline & TCM & BDCM & CDBM & TBM \\
\hline $\mathbf{1}$ & 20.32 & 21.48 & 20.23 & 20.54 \\
\hline $\mathbf{3}$ & 21.36 & 20.48 & 21.26 & 21.66 \\
\hline $\mathbf{4}$ & 19.66 & 19.42 & 20.15 & 20.58 \\
\hline $\mathbf{5}$ & 20.35 & 20.74 & 21.39 & 21.74 \\
\hline $\mathbf{6}$ & 19.34 & 21.05 & 19.87 & 20.44 \\
\hline $\mathbf{7}$ & 20.79 & 21.10 & 20.59 & 20.78 \\
\hline $\mathbf{8}$ & 21.12 & 20.16 & 20.26 & 21.28 \\
\hline $\begin{array}{c}\text { Average } \\
(\mathbf{n}=\mathbf{8})\end{array}$ & 20.15 & 20.79 & 20.43 & 20.89 \\
\hline $\begin{array}{c}\text { Standard } \\
\text { deviation } \\
(\mathbf{n}=\mathbf{8})\end{array}$ & 1.03 & 0.77 & 0.62 & 0.60 \\
\hline $\mathbf{U W L}$ & 22.20 & 22.34 & 21.66 & 22.08 \\
\hline LWL & 23.23 & 23.11 & 22.28 & 22.68 \\
\hline UCL & 17.07 & 18.46 & 18.57 & 19.11 \\
\hline LCL & 18.09 & 19.24 & 19.19 & 19.70 \\
\hline
\end{tabular}




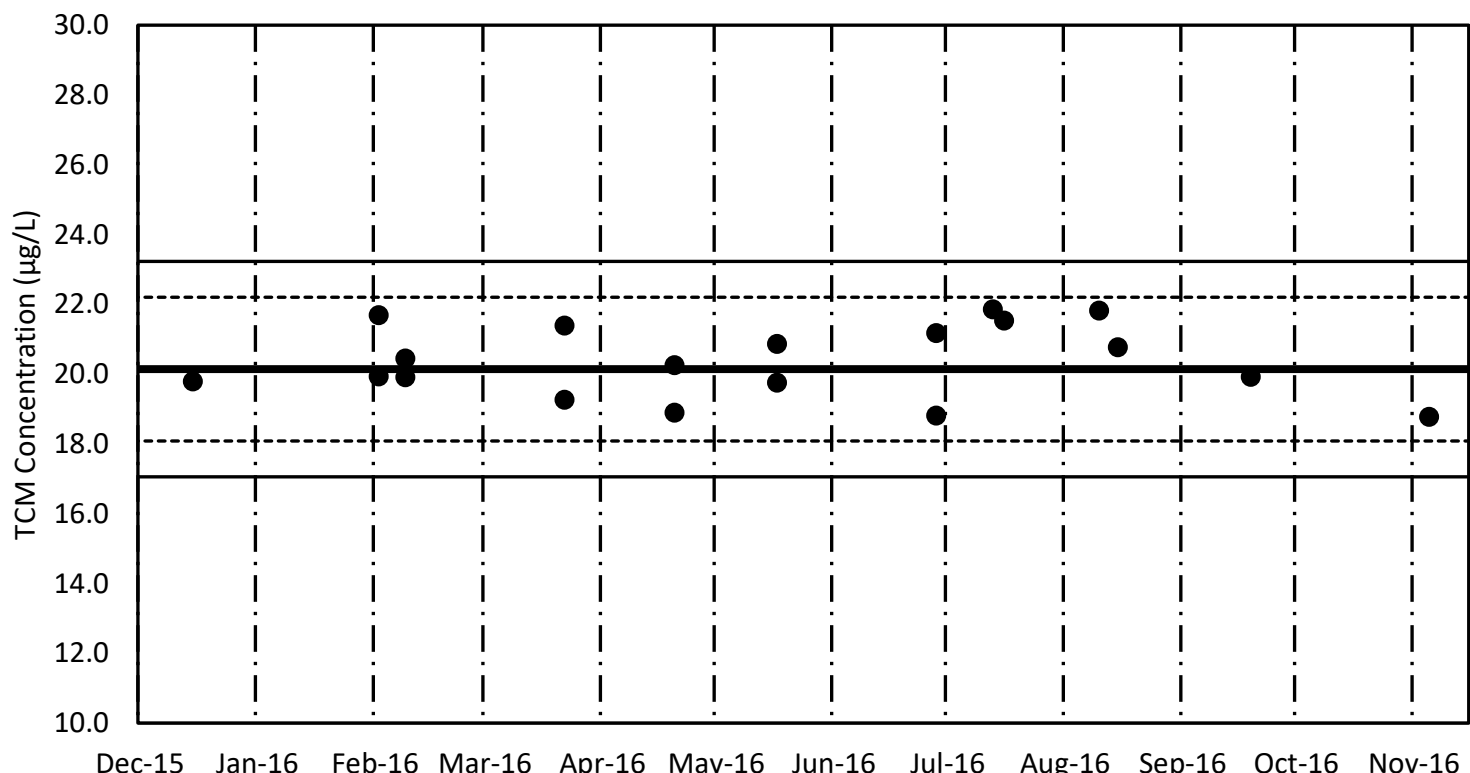

UCL

UWL

Mean

LWL

LCL

Figure 8-1: Quality Control Chart for TCM

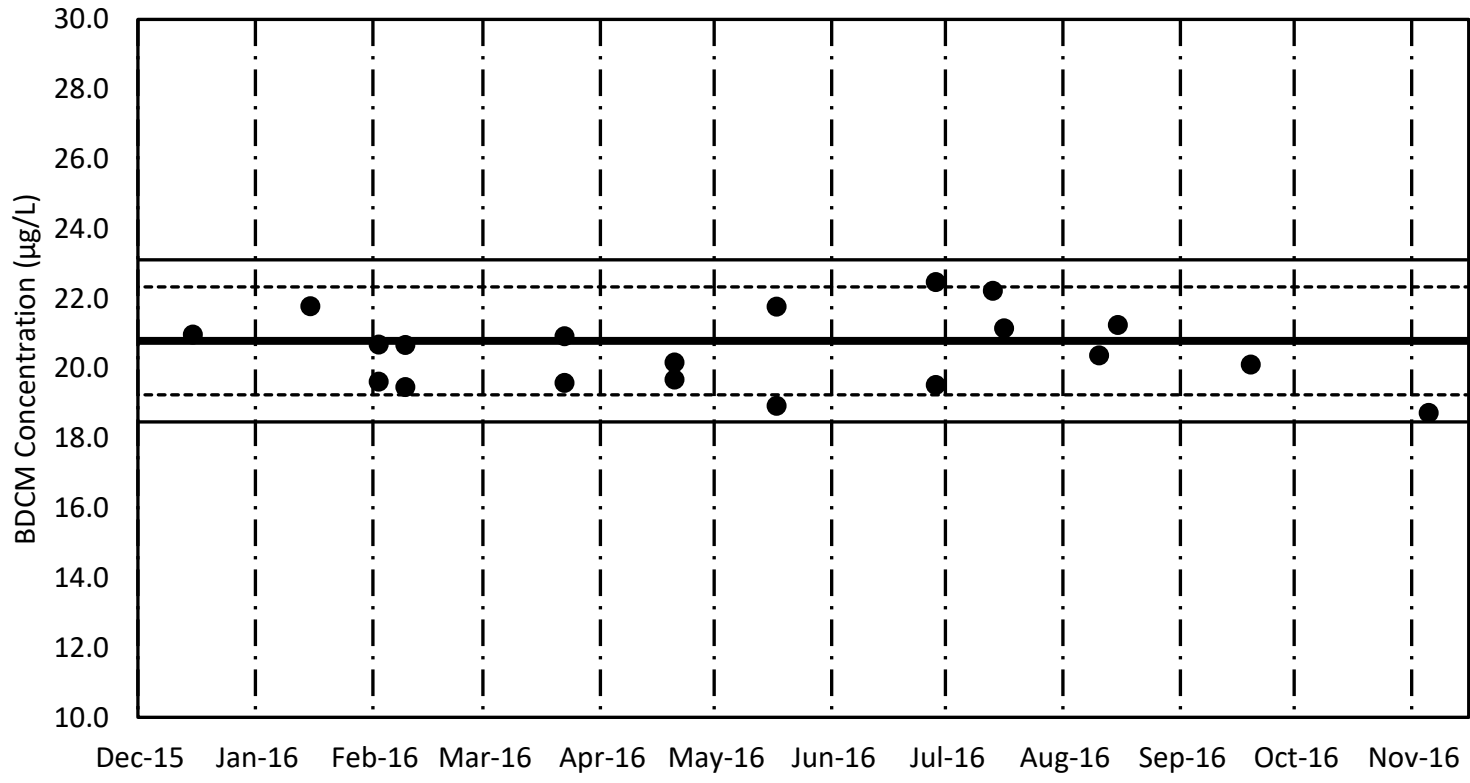

UCL

UWL

Mean

LWL

LCL

Figure 8-2: Quality Control Chart for BDCM 


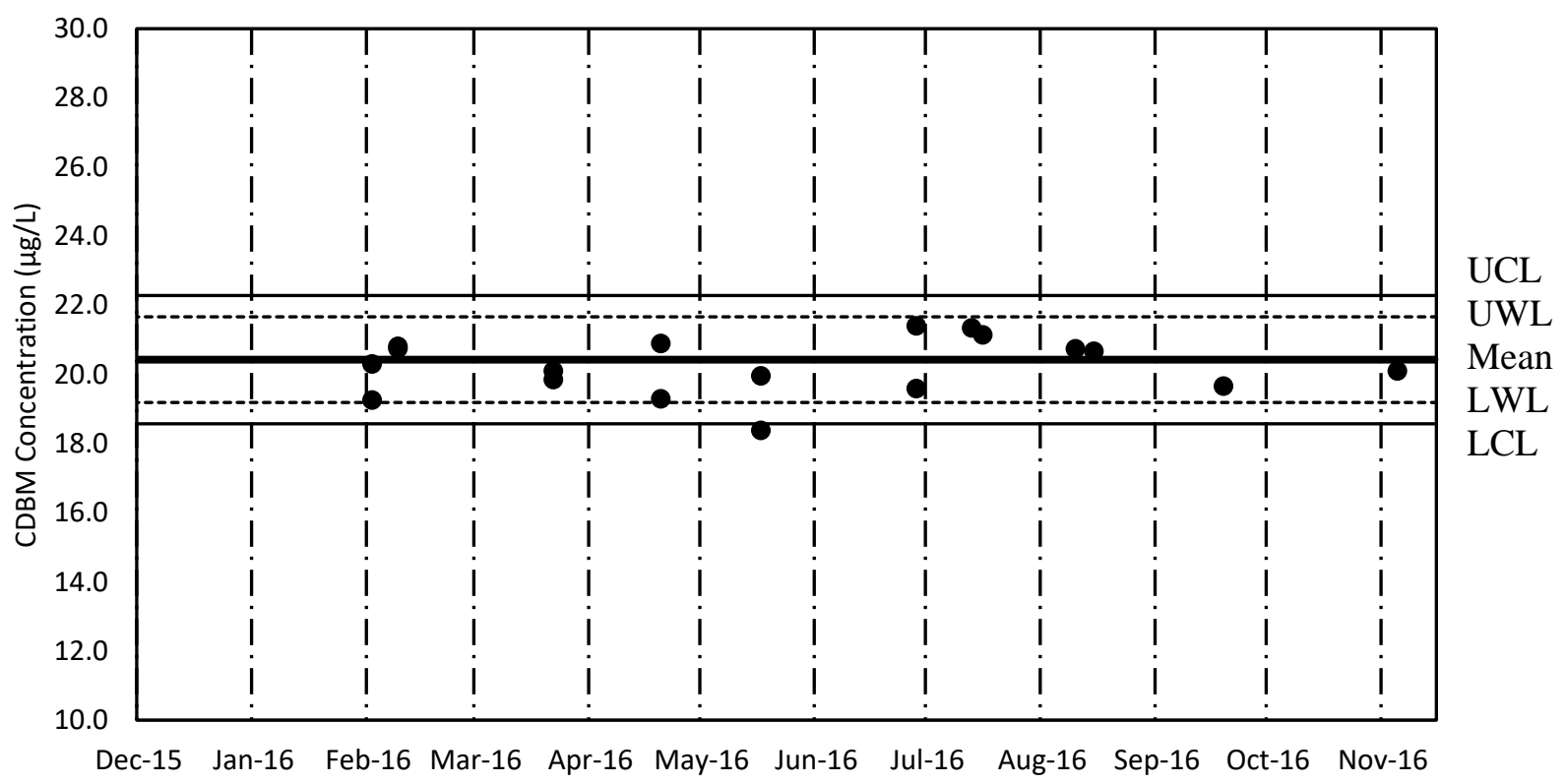

Figure 8-3: Quality Control Chart for CDBM

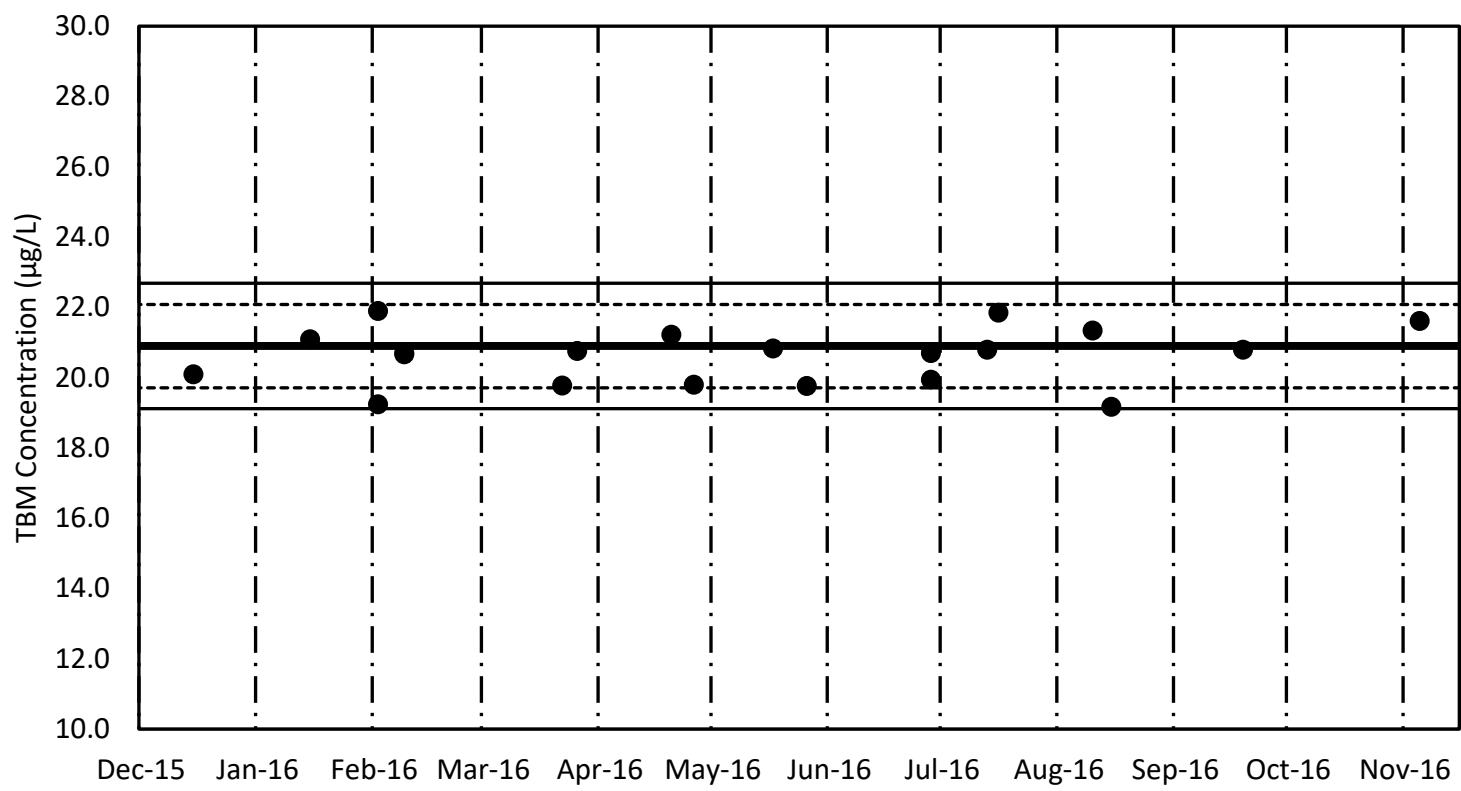

UCL

UWL

Mean

LWL

LCL

Figure 8-4: Quality Control Chart for TBM 
Table 8-10: HAA Quality Control Chart Values

\begin{tabular}{|c|c|c|c|c|c|c|c|c|c|}
\hline & MCAA & MBAA & DCAA & TCAA & BCAA & DBAA & BDCAA & CDBAA & TBAA \\
\hline 1 & 12.85 & 10.13 & 10.22 & 10.59 & 10.88 & 10.71 & 10.46 & 9.53 & 8.75 \\
\hline 2 & 11.49 & 9.48 & 9.46 & 10.53 & 10.22 & 10.45 & 9.80 & 9.94 & 9.47 \\
\hline 3 & 9.90 & 8.78 & 9.25 & 10.43 & 9.90 & 9.99 & 9.83 & 9.15 & 8.51 \\
\hline 4 & 11.56 & 8.81 & 9.29 & 10.17 & 10.52 & 10.05 & 9.18 & 9.20 & 9.19 \\
\hline 5 & 11.93 & 10.49 & 10.33 & 11.33 & 10.85 & 10.72 & 10.47 & 9.94 & 9.66 \\
\hline 6 & 11.24 & 9.39 & 9.82 & 10.75 & 10.60 & 10.52 & 10.82 & 10.01 & 9.22 \\
\hline 7 & 11.18 & 10.27 & 10.34 & 11.10 & 10.83 & 10.9 & 10.46 & 10.2 & 9.22 \\
\hline 8 & 10.64 & 9.87 & 9.89 & 11.09 & 10.64 & 10.49 & 10.46 & 9.86 & 8.93 \\
\hline Average $(n=8)$ & 11.35 & 9.65 & 9.83 & 10.75 & 10.56 & 10.48 & 10.19 & 9.73 & 9.12 \\
\hline $\begin{array}{l}\text { Standard deviation } \\
\qquad(\mathbf{n}=\mathbf{8})\end{array}$ & 0.87 & 0.65 & 0.45 & 0.39 & 0.34 & 0.32 & 0.53 & 0.39 & 0.37 \\
\hline UCL & 13.09 & 10.95 & 10.73 & 11.54 & 11.24 & 11.12 & 11.25 & 10.50 & 9.87 \\
\hline LCL & 13.96 & 11.59 & 11.18 & 11.93 & 11.58 & 11.44 & 11.79 & 10.89 & 10.24 \\
\hline UWL & 8.74 & 7.71 & 8.47 & 9.57 & 9.53 & 9.52 & 8.58 & 8.56 & 7.99 \\
\hline LWL & 9.61 & 8.36 & 8.92 & 9.96 & 9.87 & 9.84 & 9.12 & 8.95 & 8.37 \\
\hline
\end{tabular}




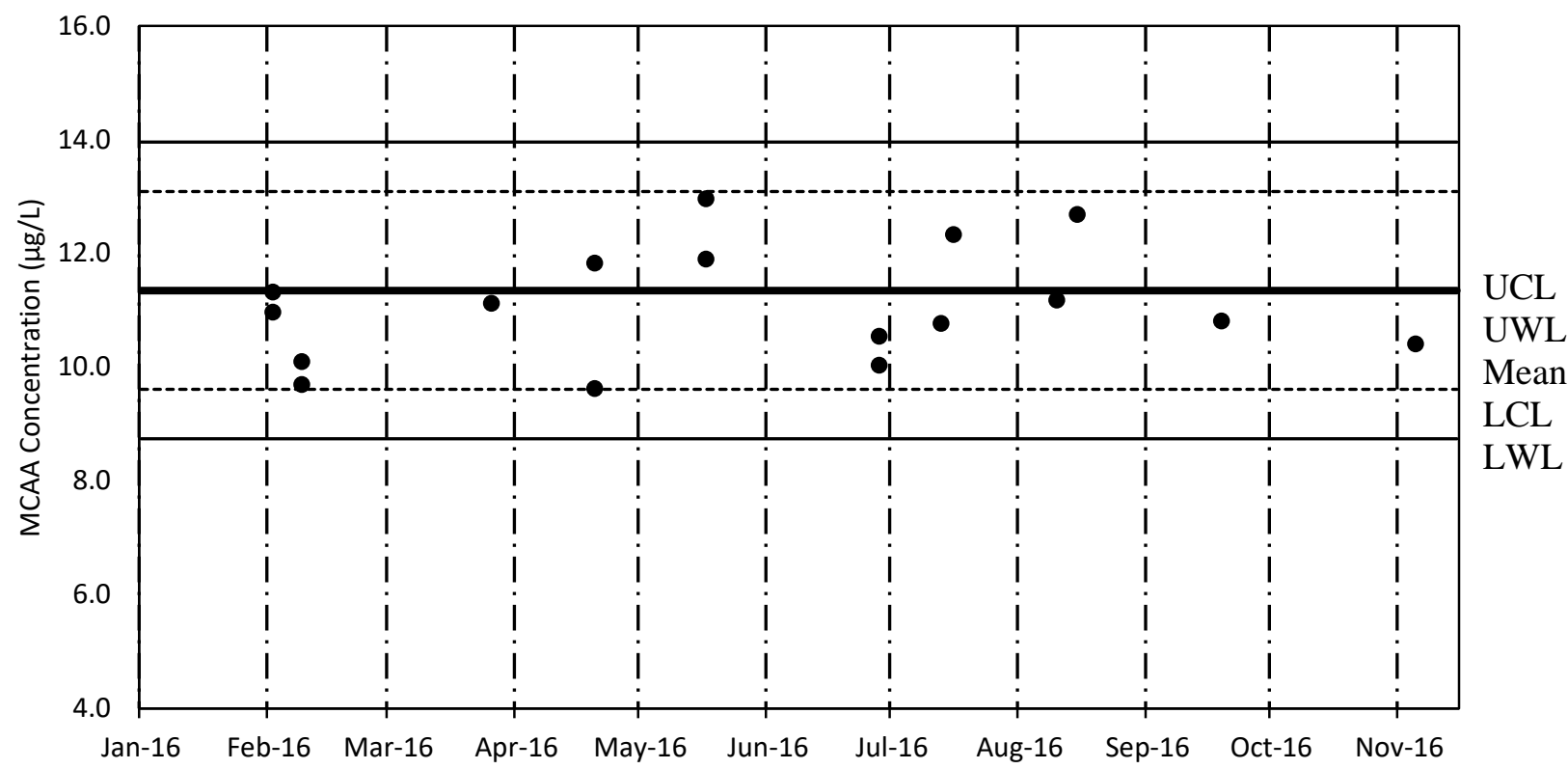

Figure 8-5: Quality Control Chart for MCAA

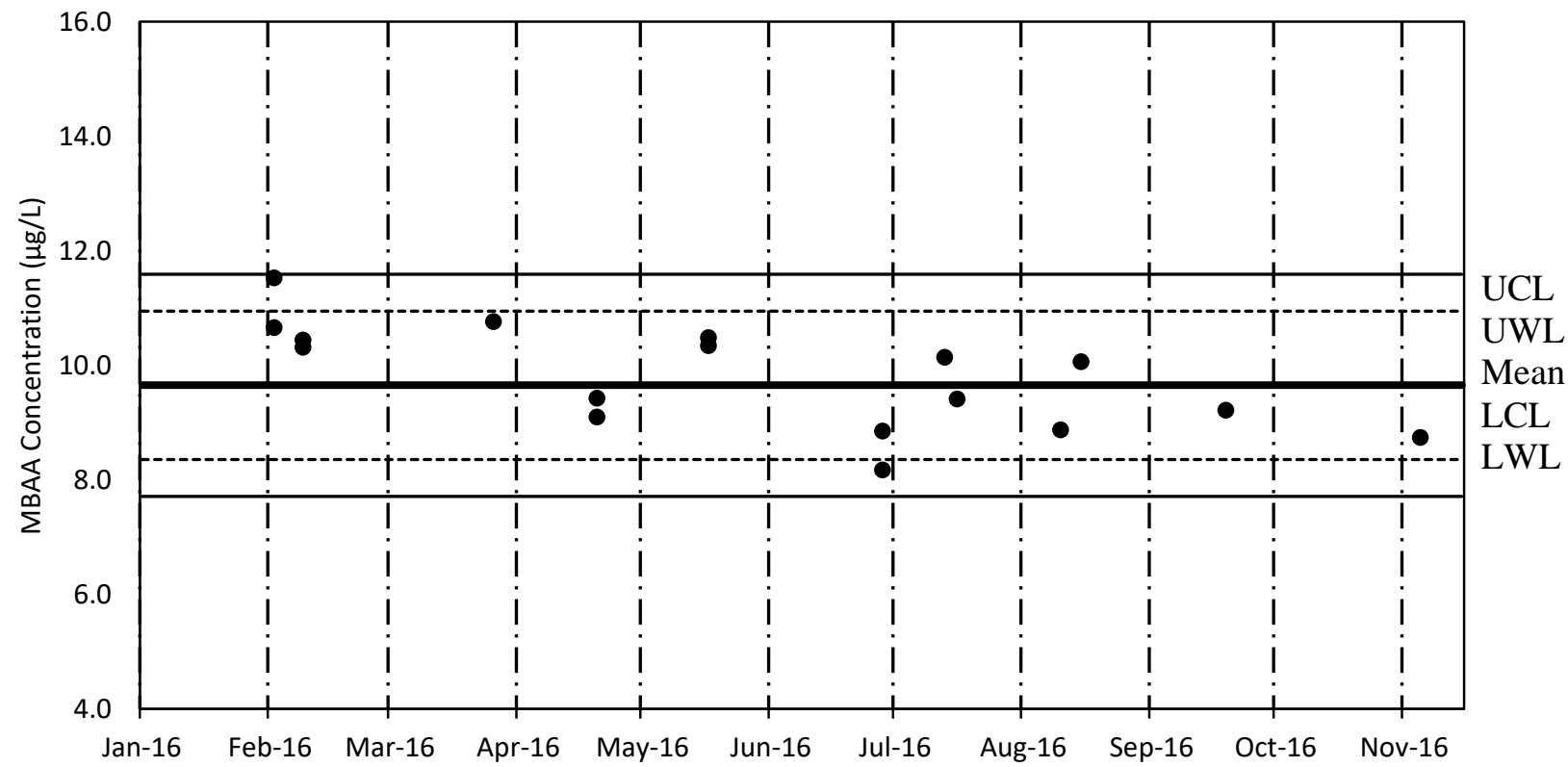

Figure 8-6: Quality Control Chart for MBAA 


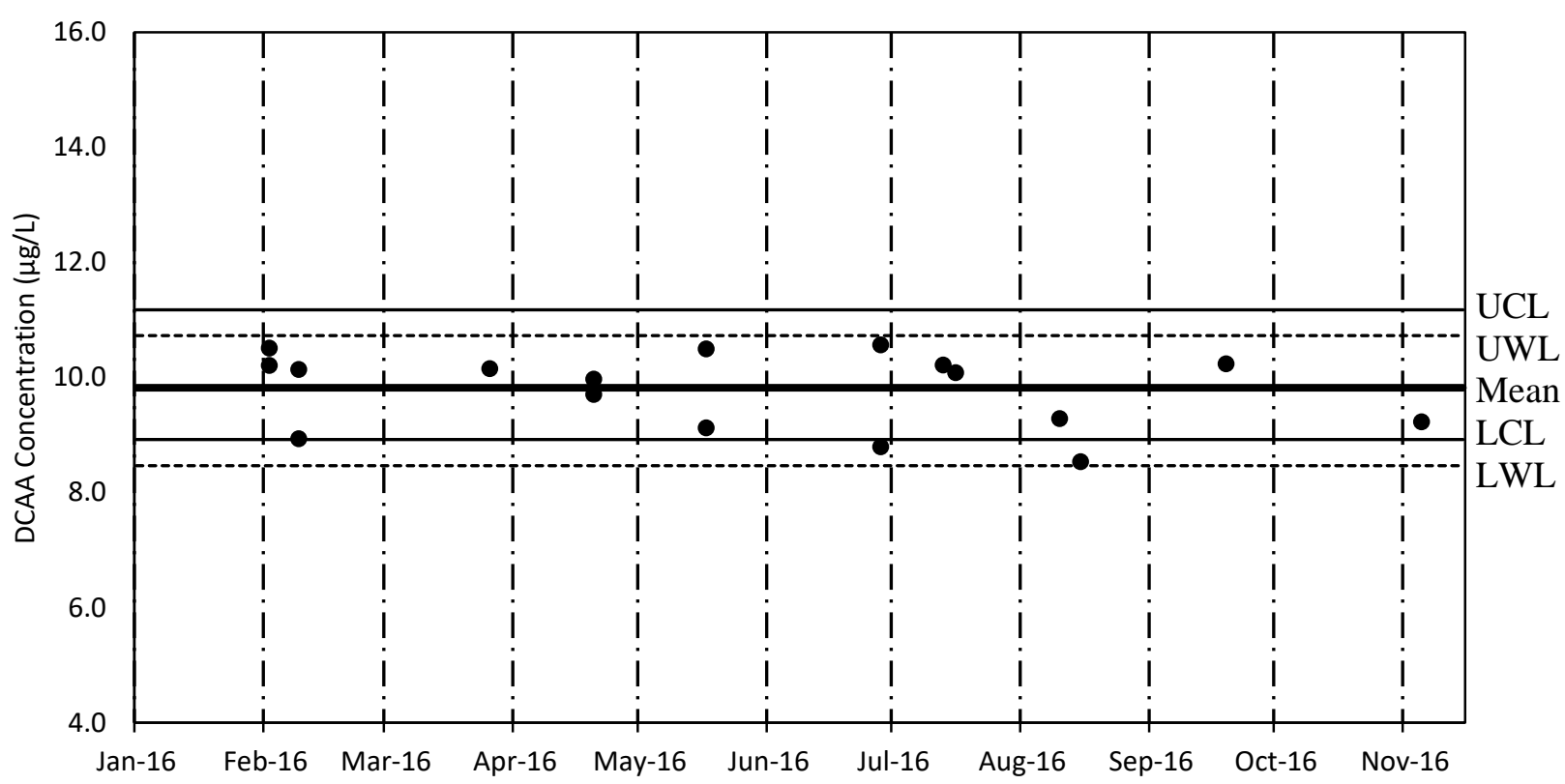

Figure 8-7: Quality Control Chart for DCAA

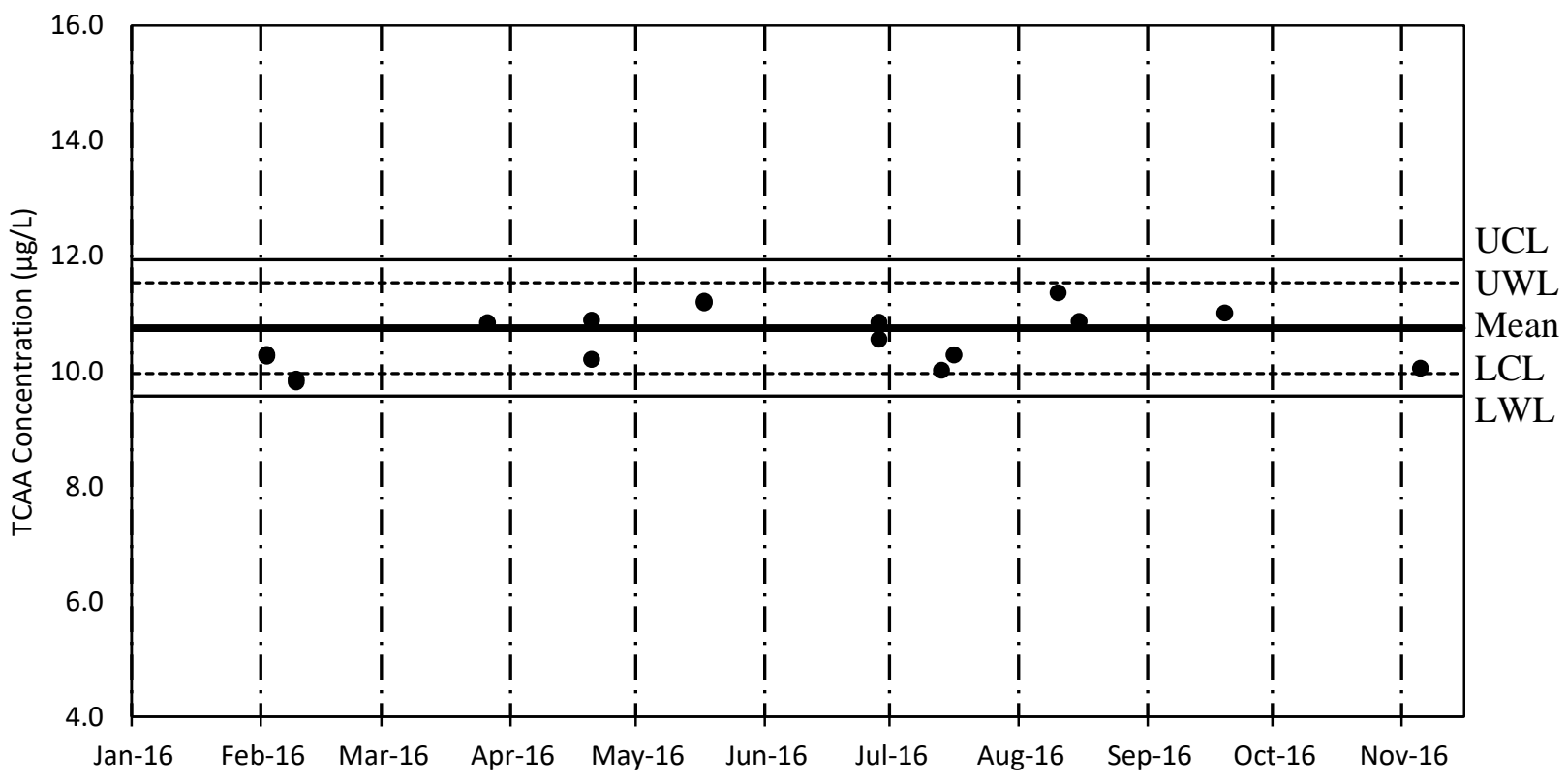

Figure 8-8: Quality Control Chart for TCAA 


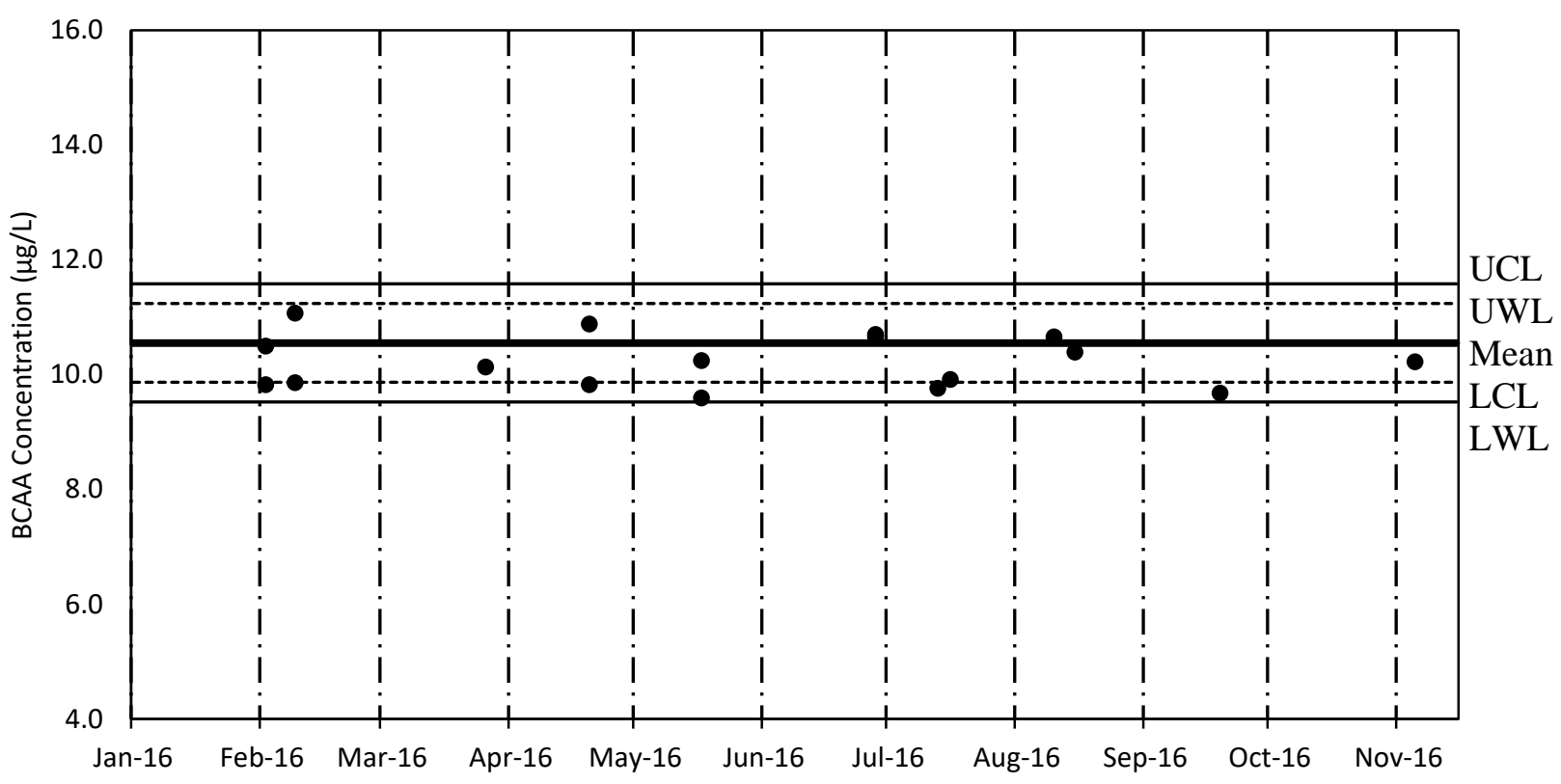

Figure 8-9: Quality Control Chart for BCAA

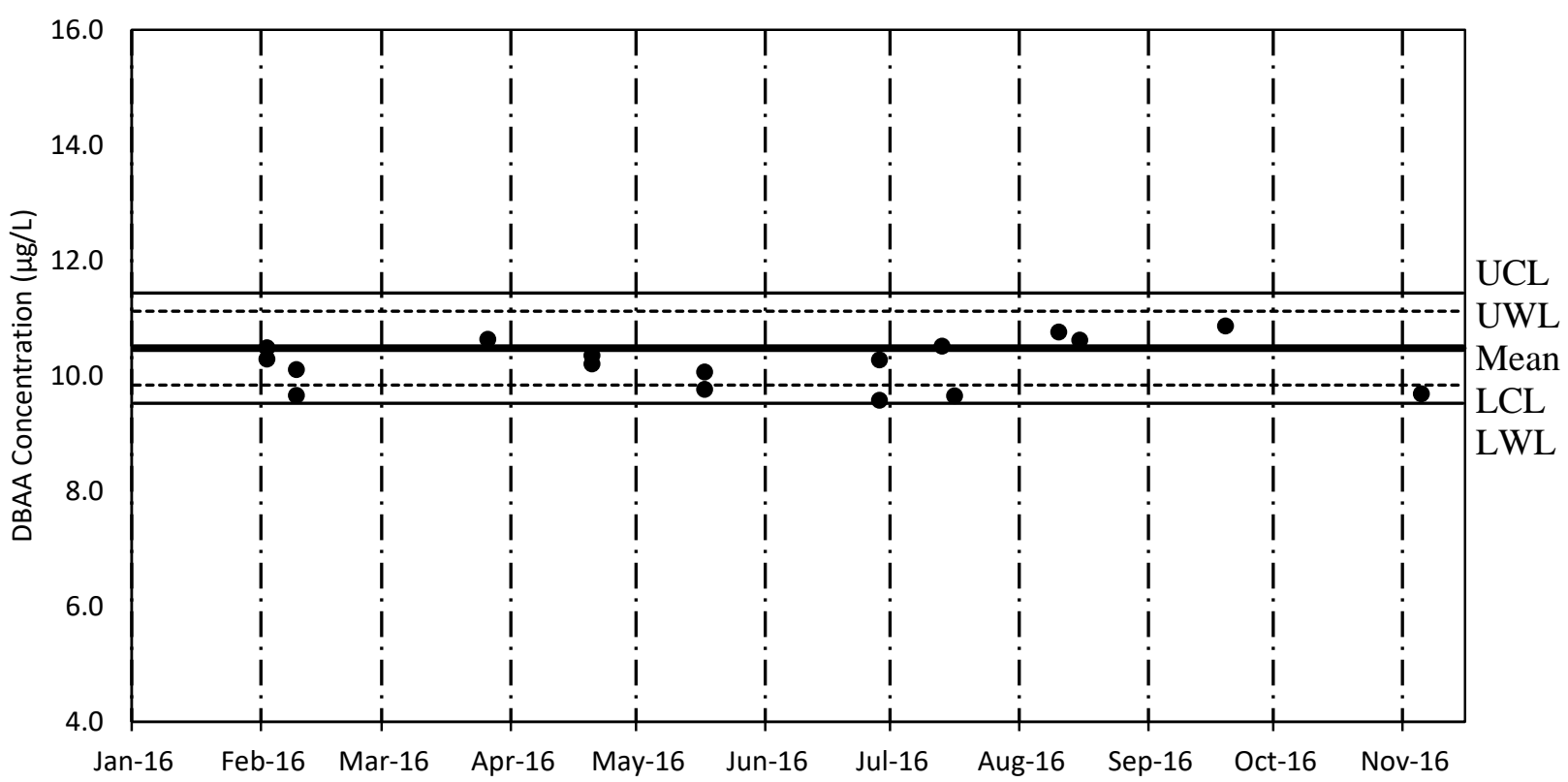

Figure 8-10: Quality Control Chart for DBAA 


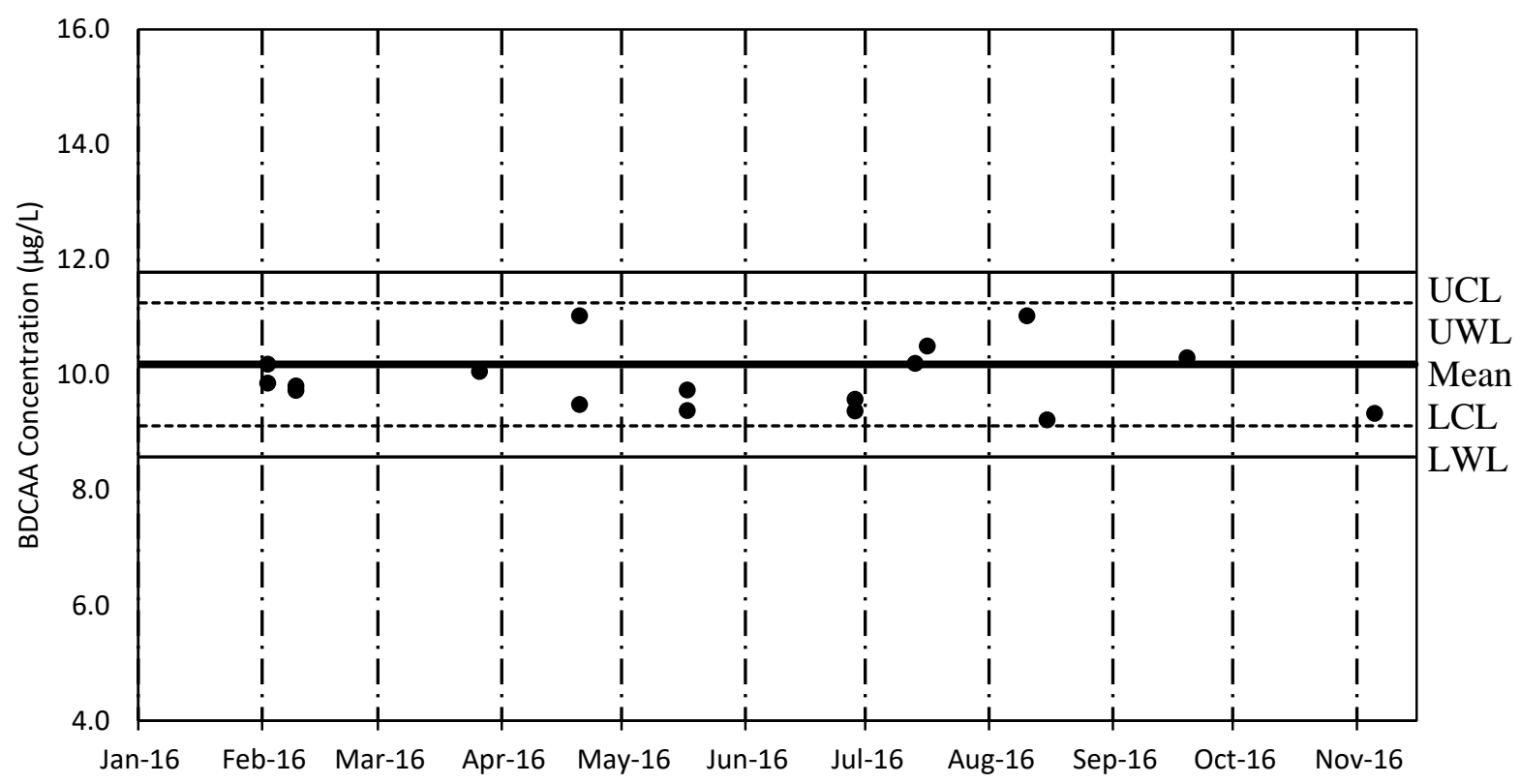

Figure 8-11: Quality Control Chart for BDCAA

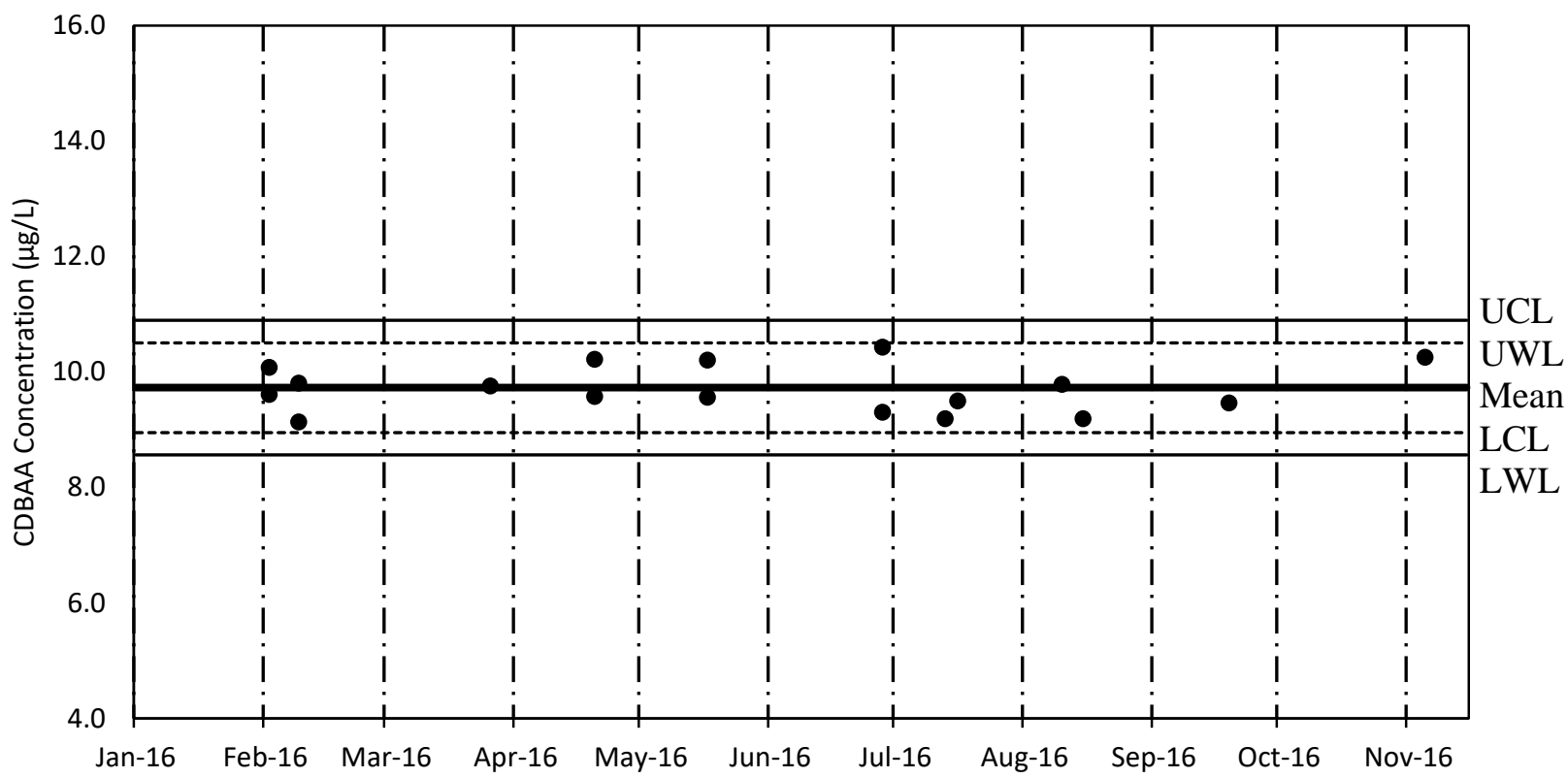

Figure 8-12: Quality Control Chart for CDBAA 


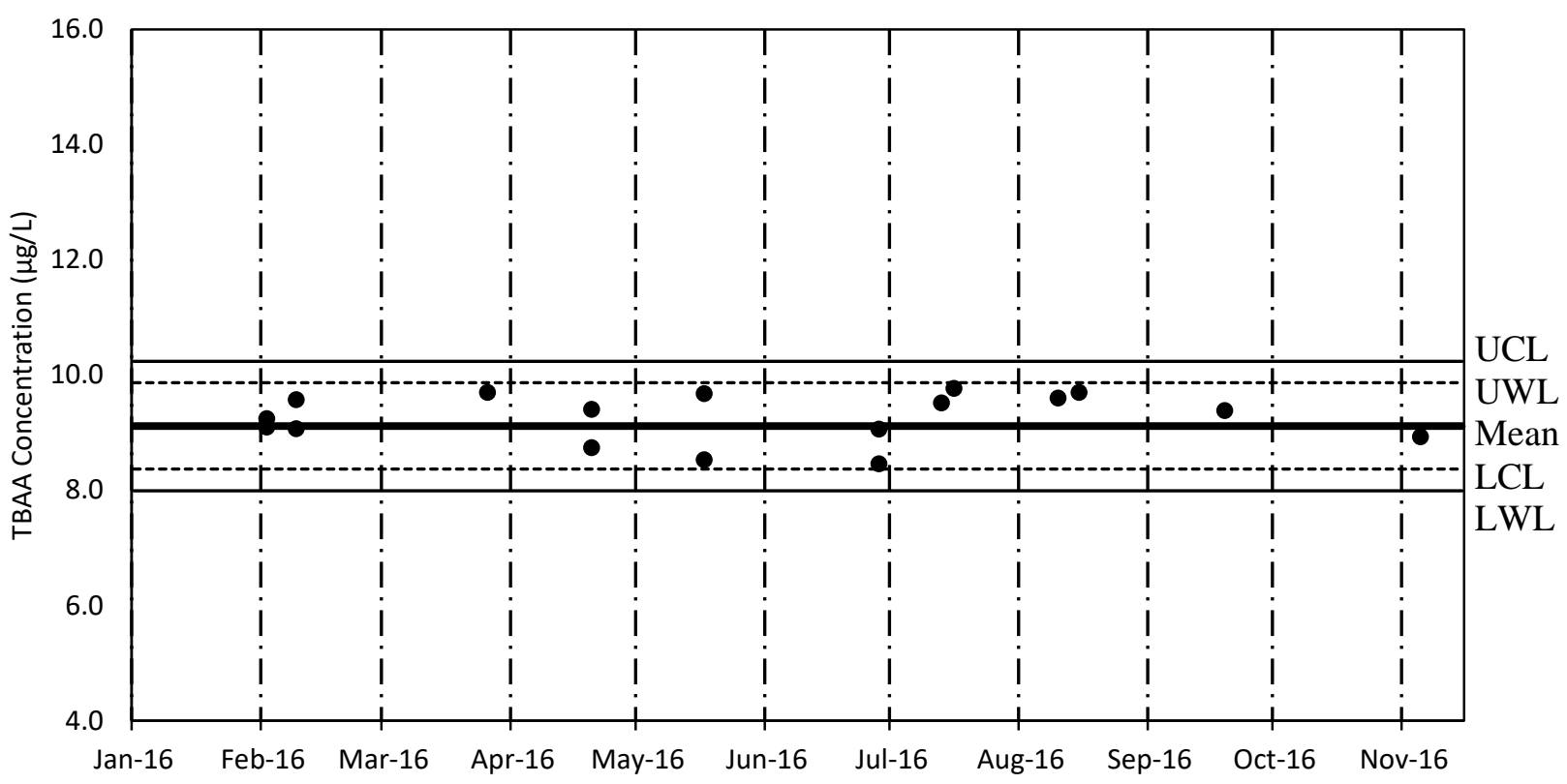

Figure 8-13: Quality Control Chart for TBAA 